\title{
Systematics, Phylogenetics, and Biogeography of Early Mississippian Camerate Crinoids of the Nunn Member, Lake Valley Formation, in south-central New Mexico
}

\author{
Elizabeth C. Rhenberg \\ West Virginia University
}

Follow this and additional works at: https://researchrepository.wvu.edu/etd

\section{Recommended Citation}

Rhenberg, Elizabeth C., "Systematics, Phylogenetics, and Biogeography of Early Mississippian Camerate Crinoids of the Nunn Member, Lake Valley Formation, in south-central New Mexico" (2011). Graduate Theses, Dissertations, and Problem Reports. 3414.

https://researchrepository.wvu.edu/etd/3414

This Dissertation is protected by copyright and/or related rights. It has been brought to you by the The Research Repository @ WVU with permission from the rights-holder(s). You are free to use this Dissertation in any way that is permitted by the copyright and related rights legislation that applies to your use. For other uses you must obtain permission from the rights-holder(s) directly, unless additional rights are indicated by a Creative Commons license in the record and/ or on the work itself. This Dissertation has been accepted for inclusion in WVU Graduate Theses, Dissertations, and Problem Reports collection by an authorized administrator of The Research Repository @ WVU.

For more information, please contact researchrepository@mail.wvu.edu. 
Systematics, Phylogenetics, and Biogeography of Early Mississippian Camerate Crinoids of the Nunn Member, Lake Valley Formation, in south-central New Mexico

\author{
Elizabeth C. Rhenberg
}

\author{
Dissertation submitted to the Eberly College of Arts and Sciences \\ at West Virginia University \\ in partial fulfillment of the requirements \\ for the degree of Doctor of Philosophy in Geology
}

\author{
Thomas Kammer, Ph.D., Chair \\ William Ausich, Ph.D. \\ Timothy Carr, Ph.D. \\ Helen Lang, Ph.D. \\ Richard Smosna, Ph.D. \\ Department of Geology and Geography \\ Morgantown, West Virginia \\ 2011
}

Keywords: Lake Valley Formation, Phylogenetics, Camerate Crinoids, Early Osagean Copyright 2011 Elizabeth C. Rhenberg 


\begin{abstract}
Systematics, Phylogenetics, and Biogeography of Early Mississippian Camerate Crinoids of the Nunn Member, Lake Valley Formation, in south-central New Mexico

Elizabeth C. Rhenberg
\end{abstract}

The Lake Valley Formation has long been known for the crinoids that are abundant in the formation. The crinoids were noted in the first descriptions of the formations in the late 1800's, but there has never been a comprehensive study done on the crinoids and as a result there is no complete list of crinoids that existed in south-central New Mexico during the Early Mississippian. Although all subclasses of crinoids are found in the Nunn Member, it is the camerate crinoids that dominate the fauna and will be the focus of this study. Most of the specimens studied came from the Macurda collection from the University of Michigan. This collection was supplemented with specimens from the Laudon collection from the University of New Mexico and additional samples collected in the field. These collections provided more than 7000 specimens to be examined, with approximately 4500 of those being identifiable camerate crinoids.

The first chapter of this paper is a systematic review of the camerates. Sixty-one species are recorded from the Nunn Member, five of which are new species: Blairocrinus macurdai, Iotacrinus novamexicana, Agaricocrinus alamogordoensis, Uperocrinus kuesi, and Collicrinus laudoni. An updated list of camerates found in the Lake Valley allows for better understanding and easier comparison of crinoid faunas across North America during this time. Environmental preferences were also examined to see if there was a difference between the faunas found in the shallow water shelf and those found associated with Waulsortian mounds in deeper water.

The majority of the camerates found in the Lake Valley Formation are from the Family Actinocrinitidae. This family has been a source of much taxonomic confusion due to generic concepts not equally applied between Europe in North America. The second chapter of this paper objectively defines the actinocrinitids by discrete characters and reevaluates the generic assignments of North American species. A phylogenetic hypothesis is presented for the relationships of the Actinocrinitidae genera based on a parsimony-based analysis and plotted against stratigraphic ranges. Although groupings were revealed in this analysis, the Actinocrinitidae cannot be readily divided into subfamilies. Twenty-one genera of Actinocrinitidae are described, 17 of which are found in North America. A total of 125 species were evaluated of which 34 species and one open-nomenclature taxon are reassigned to different genera, and four species are designated as nomina dubia.

The third chapter evaluates the similarities of camerate genera in three coeval North American formations with the Lake Valley Formation. These formations are the lower Burlington Limestone of the Mississippi Valley, the Redwall Limestone of Arizona, and the Anchor Limestone of Nevada. These similarities are based on presence-absence data with the Jaccard Coefficient and with rarefaction curves. The lower Burlington and Lake Valley faunas are nearly equal in generic richness (35 and 31 respectively) and have a high similarity (0.61). The Redwall and Anchor limestones have approximately half the number of genera that the lower Burlington and Lake Valley formations have and are very dissimilar to each other (0.18). 
The disparity in number of genera in the Redwall and Anchor limestones as compared to the lower Burlington and Lake Valley are likely taphonomic. The camerates of the Redwall are poorly preserved, likely due to early diagenesis of chert and dolomite. In the Anchor, the camerates were likely moved in debris flows from shallow water settings, diminishing their preservation potential. Because neither the Redwall nor the Anchor have significant numbers of unique genera and both have genera that are a subset of the lower Burlington fauna, the seas of North America were likely well connected during the Early Mississippian, allowing for the camerates to widely disperse. Rarefaction curves indicate that the Redwall and Anchor limestones have been incompletely sampled. Thus, poor preservation and limited sampling in these formations have produced an apparently endemic pattern for faunas that were originally cosmopolitan. 


\section{PREFACE - A Note on Organization}

The following doctoral dissertation was completed in the form of three articles ready for submission to peer-reviewed journals. Because of this format, there is some repetition of general information and the figures and tables are found at the end of the each chapter.

The papers are treated as separate chapters. The first chapter is a systematic review of the camerates of the Nunn Member. The second chapter is a review of the genera within the Family Actinocrinitidae and a phylogenetic analysis of the family. The third chapter is a biogeographic comparison of camerate crinoids of the Nunn Member to three coeval formations: the lower Burlington of Iowa, the Redwall Limestone of Arizona, and the Anchor Limestone of Nevada. 


\section{ACKNOWLEDGMENTS}

This research was supported by grants from the Eberly College of Arts and Sciences, the Department of Geology and Geography at West Virginia University, and the Shumaker Fund. Most of the material studied was collected by Dr. Brad Macurda during the 1960s and 70s while he was at the University of Michigan. I thank Dr. Macurda for providing his collection for my study. Dr. Barry Kues of the University of New Mexico provided helpful assistance in the field guiding us to various sites where the Lake Valley Formation outcrops in New Mexico and in allowing us to borrow from the Laudon collection. Dr. William Ausich of the Ohio State University provided a constructive review on the second chapter as well as helpful information throughout the writing of the first two chapters.

I would lastly like to thank Dr. Thomas Kammer, my Ph.D. adviser, for the help and advice that he provided throughout the identification of crinoids and the writing process. He made a significant contribution to this research with his seemingly endless knowledge on crinoids. 


\section{TABLE OF CONTENTS}

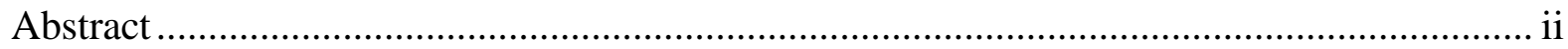

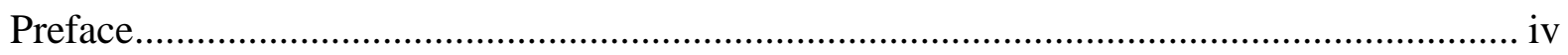

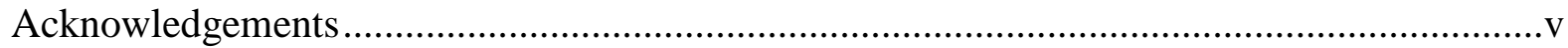

Chapter 1: Systematic review of camerate crinoids of the lower Mississippian Lake Valley Formation (Nunn Member, Osagean), New Mexico .........................................................1

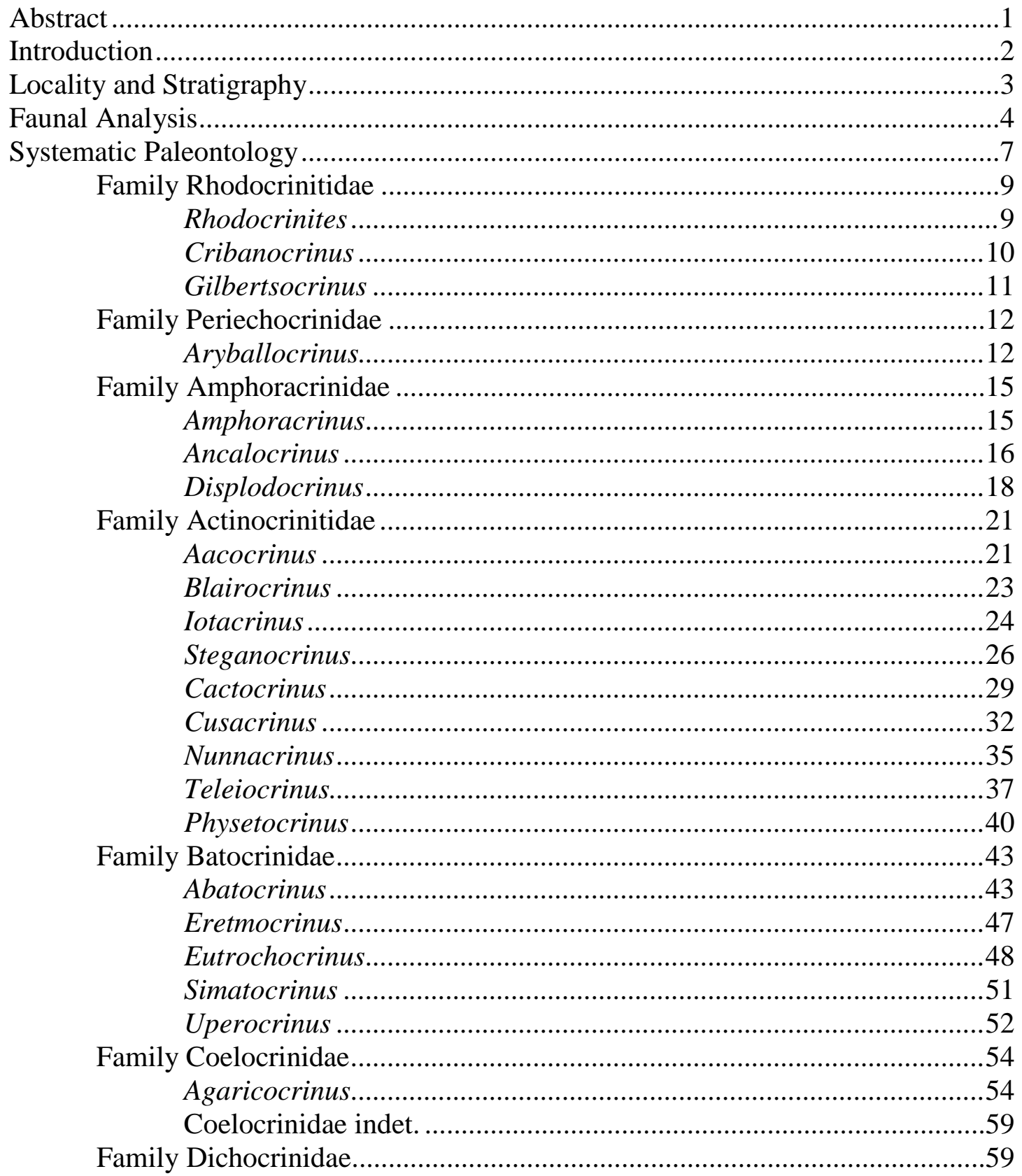




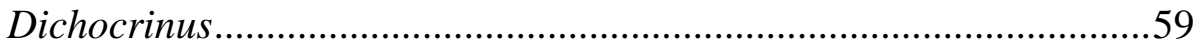

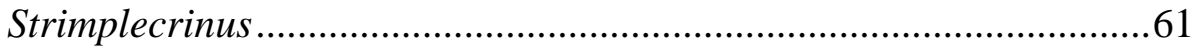

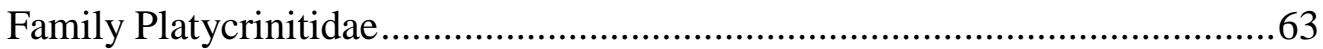

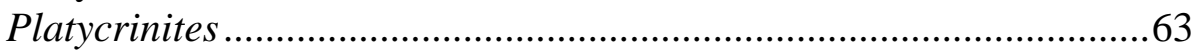

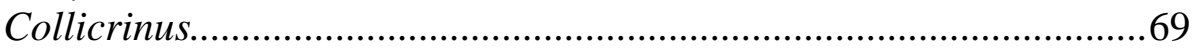

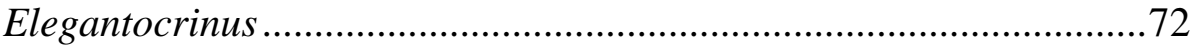

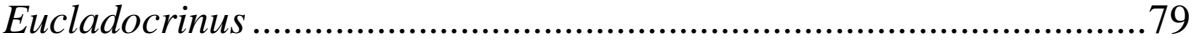

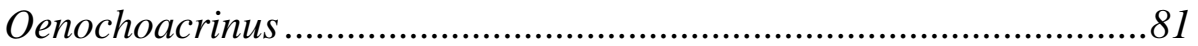

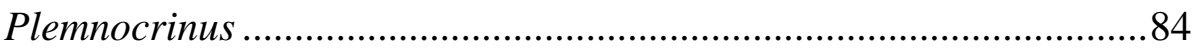

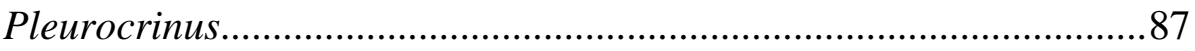

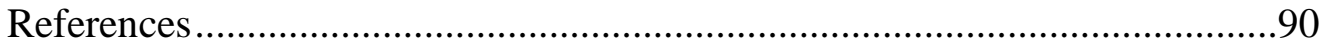

Chapter 2: Generic Concepts in the Actinocrinitidae Austin and Austin, 1842 and Evaluation of Generic Assignments of North American Species........................................................150

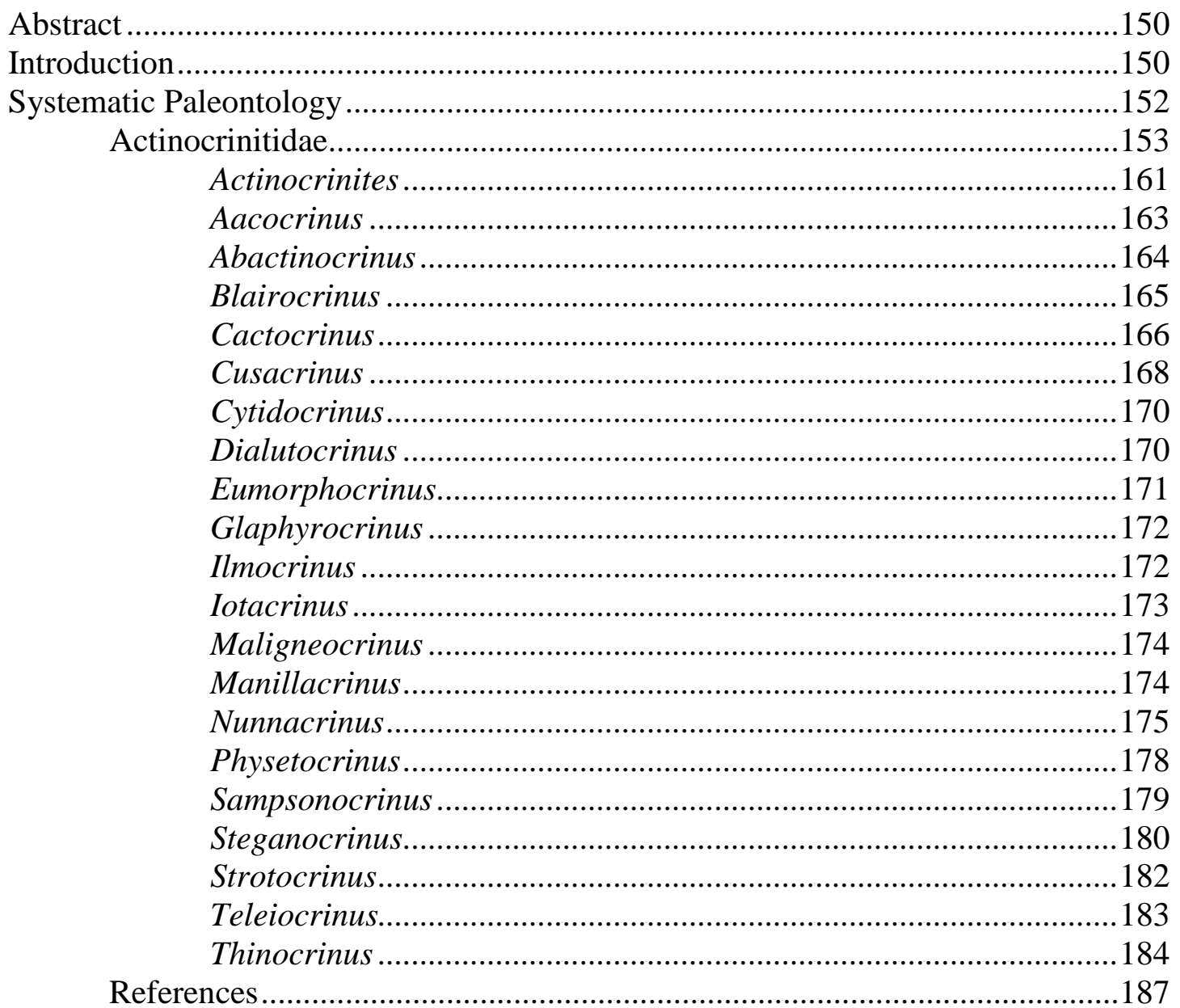

Chapter 3: Did North American Mississippian Camerate Crinoids have an Endemic or Cosmopolitan Biogeographic Distribution during the Early Osagean?...............................204

Abstract 


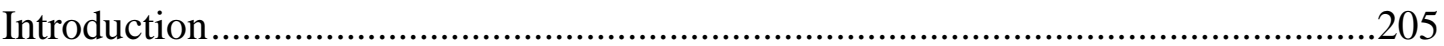

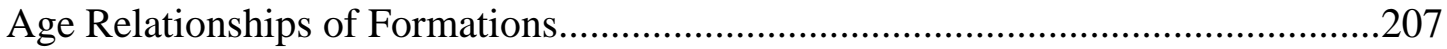

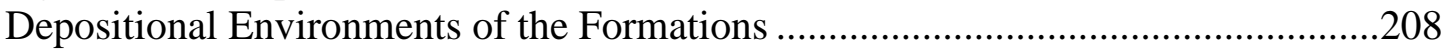

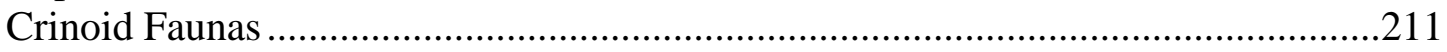

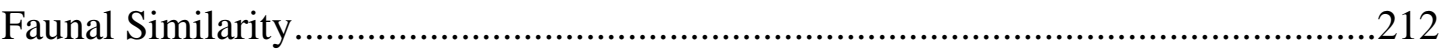

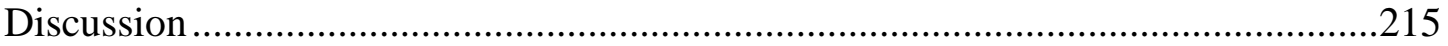

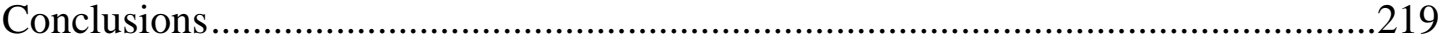

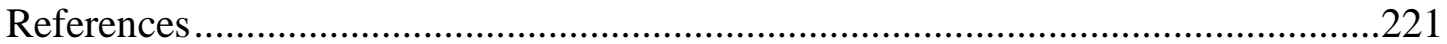

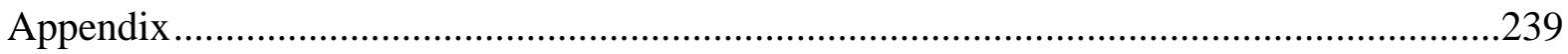

Appendix 1 - Locality information for collecting sites .........................................239

Appendix 2 - Township and range information for Macurda localities ....................241

Appendix 3 - Interradial plate counts for Nunnacrinus..........................................243

Appendix 4 - Characters for phylogenetic analysis .............................................260

Appendix 5 - Character chart for phylogenetic analysis .........................................261 


\section{LIST OF TABLES}

Table 1.1. Distribution of Lake Valley Camerates across North America ..........................104

Table 1.2. Measurements of Blairocrinus macurdai n. sp...............................................106

Table 1.3. Blairocrinus macurdai compared to other known Blairocrinus species .............107

Table 1.4. Measurements of Iotacrinus novamexicana n. sp.........................................108

Table 1.5. Iotacrinus novamexicana compared to other known Iotacrinus species.............109

Table 1.6. Measurements of Uperocrinus kuesi n. sp.....................................................110

Table 1.7. Uperocrinus kuesi compared to similar Uperocrinus species ...........................111

Table 1.8. Measurements of Agaricocrinus alamogordoensis n. sp..................................112

Table 1.9. Agaricocrinus alamogordoensis compared to similar Agaricocrinus species.....113

Table 1.10. Measurements of Collicrinus laudoni n. sp.................................................114

Table 1.11. Collicrinus laudoni compared to other Collicrinus species..............................115

Table 2.1. List of actinocrinitid species with new generic assignments ............................196

Table 2.2. Chronostratigraphic correlation of time units for North America and Europe....197

Table 2.3. Diagnostic characters of the calyx and tegmen of Actinocrinitidae genera ........198

Table 3.1. Camerate genera found in the lower Burlington, Nunn Member of the Lake Valley, Redwall, and Anchor formations ....................................................................................225

Table 3.2. Similarity matrix based on the Jaccard Coefficient based on consideration of all

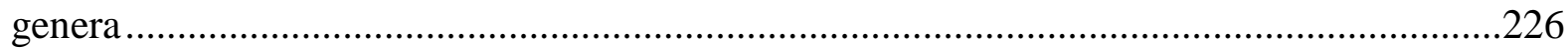

Table 3.3. Genera counts for the Burlington, Lake Valley, Redwall, and Anchor formations: actual counts and similarity percentage based on shared genera..... 


\section{LIST OF FIGURES}

Figure 1.1. Map of New Mexico showing collecting sites

Figure 1.2. Comparative stratigraphic column between the Lake Valley Formation and Burlington Limestone

Figure 1.3. Paleogeographic map of the Lake Valley Formation 118

Figure 1.4. Map of localities in the Black Range

Figure 1.5. Map of localities in Sacramento Mountains 120

Figure 1.6. Q-Mode MDS plot using Jaccard Coefficient showing the distribution of the 16 collecting localities.

Figure 1.7. Crinoids from the families Rhodocrinitidae (diplobathrid) and Periechocrinidae (monobathrid).

Figure 1.8. Crinoids from the family Amphoracrinidae

Figure 1.9. Crinoids from the family Actinocrinitidae, subfamily Actinocrinitinae 126

Figure 1.10. Chart showing the ratio differences between the protuberance of arm rays between Blairocrinus arrosus and B. macurdai n. sp. 128

Figure 1.11. Crinoids from the family Actinocrinitidae, subfamily Cactocrininae 129

Figure 1.12. Plots showing the interradial plate number that separates the rays on the 61 Nunnacrinus specimens found in the Springer Room of the Smithsonian

Figure 1.13. Crinoids from the family Actinocrinitidae, subfamily Cactocriniae, subfamily Physetocrininae and family Batocrinidae 133

Figure 1.14. Width-height ratio of the tegmens of 37 specimens of Physetocrinus copei ...135

Figure 1.15. Crinoids from the family Batocrinidae. 136

Figure 1.16. Crinoids from the families Batocrinidae and Coelocrinidae 138

Figure 1.17. Crinoids from the families Coelocrinidae and Dichocrinidae 140

Figure 1.18. Crinoids from the families Dichocrinidae and Platycrinitidae...... 142

Figure 1.19. Crinoids from the family Platycrinitidae. 144

Figure 1.20. Crinoids from the family Platycrinitidae 146 
Figure 1.21. Crinoids from the family Platycrinitidae .................................................148

Figure 2.1. Phylogenetic analysis of 21 genera of actinocrinitids ..................................202

Figure 3.1. Paleogeographic reconstruction of North America in the early Mississippian ..228

Figure 3.2. Correlated stratrigraphic columns of the Mississippi Valley, New Mexico, Arizona, and Nevada formations for the Osagean and early Meramecian .......................................229

Figure 3.3. Specimen counts for the Lake Valley, Redwall, and Anchor formations ..........230

Figure 3.4. Graphs based on the Jaccard Coefficient showing the similarity between the

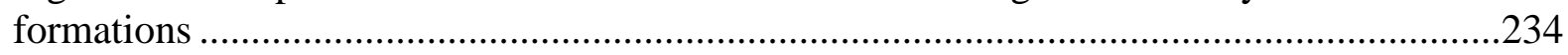

Figure 3.5. Rarefaction curves comparing the generic richness between the Burlington Limestone, Lake Valley Formation, Redwall Limestone, and Anchor Limestone ..............236 
Chapter 1:

Systematic review of camerate crinoids of the lower Mississippian Lake Valley Formation (Nunn Member, Osagean), New Mexico

Elizabeth C. Rhenberg and Thomas W. Kammer

\begin{abstract}
The Nunn Member (Early Osagean) of the Lake Valley Formation of New Mexico is known for its abundance of crinoids. Although the formation was first described in the late 1800's, there has not been a comprehensive study on its crinoids, and a complete list of the crinoid genera does not exist. All subclasses of crinoids occur in the Lake Valley, but the camerates are by far the dominant group. Study of the Macurda collection from the University of Michigan, the Laudon collection from the University of New Mexico, and what was personally collected in the field has provided more than 7000 specimens to be examined, 4500 of which were identifiable camerates. Sixty-one species of camerates have been recorded in the Nunn Member, including five new species: Blairocrinus macurdai, Iotacrinus novamexicana, Agaricocrinus alamogordoensis, Uperocrinus kuesi, and Collicrinus laudoni. These camerates share a high similarity with the lower Burlington Limestone of the Mississippi Valley. An update of the crinoid genera in the Lake Valley Formation allow for a better understanding and easier correlation of crinoid faunas across North American during the Early Mississippian. The majority of the camerates are in the western outcrops where the Nunn is thicker and the environment was shallower but several are found in association with the deep water Waulsortian mounds for which the Lake Valley Formation is famous. By using Jaccard Coefficient and Non-Metric Multidimensional Scaling, a difference in crinoid preferences for shallower or deeper water is demonstrated.
\end{abstract}




\section{INTRODUCTION}

The Lake Valley Formation occurs on either side of the Rio Grande Rift of southern New Mexico and consists of six members: Andrecito, Alamogordo, Nunn, Tierra Blanca, Arcente and Dona Ana (Laudon and Bowsher, 1949). The formation has a rich Early Mississippian fauna, especially crinoids, that are well preserved (Kues, 1986). However, despite their abundance, relatively little work has been published on the Lake Valley crinoids. The crinoids have only been mentioned in general faunal lists of the formation (Anonymous, 1881; Miller, S. A., 1881; Cope, 1882; Springer, 1884; Kues, 1986; 2008), as a part of larger studies on crinoids (Wachsmuth and Springer, 1897; Bowsher; 1955; Brower, 1965), or in microcrinoid studies (Strimple and Koenig, 1956; Lane, Sevastopulo, and Strimple, 1985). Information is so incomplete and outdated that several relatively abundant genera identified during this study are not listed from the Lake Valley Formation in Webster's (2003) Index.

The focus of this study will be the camerate crinoids. Although examples of all Paleozoic crinoid subclasses are in the Lake Valley, the camerates are the most abundant crinoids not only in generic richness, but also in number of specimens collected (>95\%). Webster's (2003) Index only lists 14 genera and 25 species of camerates reported in previous literature. The camerates identified in this study have increased the number to 32 genera and 63 species, or $129 \%$ and $152 \%$, respectively. The number of species described herein is much closer to the number that Kues (1986) reported (61 species), although he did not list those known species, nor does he specify how many fall into the different subclasses of crinoids. Kues (2008) mentioned that more than 100 species of crinoids have been reported, but only a third have been described and 
illustrated. This study will focus on just the Nunn Member of the Lake Valley Formation. Crinoids occur in all six members, but the Nunn Member holds the classic crinoid fauna (Laudon and Bowsher, 1949), representing the overwhelming majority of known specimens.

The crinoids that make up the bulk of the specimens studied are on loan from the University of Michigan. They were collected by Dr. Brad Macurda and his students while he worked at the University of Michigan in the 1960's and 1970's. The collection consists of more than 7,000 specimens of crinoids that were collected from more than 45 different sites in southern New Mexico (Fig. 1.1). Additional specimens from the Laudon collection are on loan from the University of New Mexico.

\section{LOCALITY AND STRATIGRAPHY}

The study area is located on either side of the Rio Grande Rift in southern New Mexico, near Lake Valley, NM in the western Black Range and Alamogordo, NM in the eastern Sacramento Mountains (Fig. 1.1, 1.2-3). Most of the collecting was done in the western part of the formation where the Nunn Member is thickest.

The Nunn Member is a highly fossiliferous, soft, blue-grey to greenish-grey nodular packstone to wackestone interbedded with shales and argillaceous limestones (Laudon and Bowsher, 1949; Jicha, 1954; Pray, 1951; Kues, 1986; Frank et al., 1996; Brezinski, 2000). The exposures are best in the western extent of the Lake Valley Formation, becoming as thick as $60 \mathrm{~m}$ near Santa Rita (Kues, 1986). In the Sacramento Mountains, the Nunn is thickest in the north (3m; Laudon and Bowsher, 1949), thinning southward until it eventually disappears (Lane, H. R., 1982; 1984). The difference in thickness is due to a change in paleogeographic setting. The 
Nunn Member in the Sacramento Mountains represents biohermal flank beds, on to the well studied Waulsortian Mounds, and was deposited in deeper water along the shelf break (Brezinski, 2000). In the Black Range, the Nunn Member was deposited as a level bottom facies in a shelf environment.

Conodont biostratigraphy indicates correlation of the Lake Valley Formation to the Burlington Limestone in Iowa. H. R. Lane (1974) divided the Mississippian strata of New Mexico into 11 faunal units based on the conodonts. His correlations placed the Nunn Member as equivalent to the Fern Glen Formation and the lower part of the Burlington Limestone (Lane and Brenckle, 2001), which is conodont faunal unit 3 (Fig. 1.2).

\section{FAUNAL ANALYSIS}

One goal of this study is to determine if there were any differences between the crinoids on either side of the Rio Grande Rift. The crinoids to the east are associated with deeper-water Waulsortian Mounds. These mounds grew on the outer ramp, below wave base (Jeffery and Stanton, 1996). The crinoids to the west lived in a shallower shelf environment (Brezinski, 2000), similar to the Burlington Shelf. The difference in environments could be a cause for a difference in crinoid distribution (Fig. 1.3).

The localities were divided based on the information provided by Macurda and Laudon on their specimen labels and grouped so that localities near to each other in the same topographic feature were combined for analysis. By doing this, the number of localities was reduced to a manageable 18 as opposed to 54 (Macurda’s 45 localities and 9 Laudon localities). These 18 localities account for $98 \%$ of the camerates studied. The other $2 \%$ have no locality information 
(other than a statement that says they come from the Lake Valley Formation) or were found in the San Andres Mountains, which are difficult to access because they lie in the White Sands Missile Range where access is restricted by the U. S. military. Specimens from San Andres Mountains account for only $0.2 \%$ of the total amount.

Most of the localities (15) are in the western portion of the field area. All localities in Sierra County are technically part of the Black Range, but specific names are given where possible. Locality names are based on the Macurda or Laudon labels, but all localities were not given a site name. The two collecting localities that generated the largest number of specimens (M-15 and M-17) were not given a location name and thus remain as occuring in the Black Range. The undefined Black Range localities are between the P A Mountain localities and the Tierra Blanca Mountain localities (Fig. 1.4).

Several specimens from Laudon’s collection were collected at Pryor Nunn Ranch, now known as Tierra Blanca Ranch. The ranch is located on Tierra Blanca Mountain, therefore all of those specimens are given the locality name of Tierra Blanca Mountain to prevent confusion for any future ranch name changes. Cook Range is located south of the Black Range in Luna County (Fig. 1.1).

Laudon’s location of Wittenburg Ranch Windmill Section is unknown. There are no geographic coordinates on the labels, so it is unclear as to the location of the ranch. An internet search placed a Wittenburg Ranch near Separ, NM (Fig. 1.1) in Grant County, and according to Laudon and Bowsher (1949) the Lake Valley Formation does outcrop in that area. Therefore, Wittenburg Ranch has very tentatively been placed outside Separ, NM (Fig. 1.1). To confuse matters more, there are some specimens that have labels saying the Windmill Section is part of 
the Pryor Nunn Ranch localities. There may have been a mistake in labeling, multiple Windmill Sections, or a single Windmill Section shared among two collecting sites. Though the exact location of Laudon's Wittenburg Ranch locality may not be known, it is certainly in the western portion of the study area.

The localities listed as being Indian Wells Canyon, Marble Canyon, and Grapevine Canyon are all in the eastern outcrops of the formation. These canyons are a feature of the Sacramento Mountains in Otero County (Fig. 1.4).

All locality information that is available for the collecting sites is listed in Appendices 1 and 2.

Presence-absence data were used with the Jaccard Coefficient for Non-Metric Multidimensional Scalding (MDS), using PAST software (Hammer et al., 2001), to compare the two regions of the study area. Two of the localities (Berenda Canyon and Wilson Ranch) only had a single taxon each, which caused them to be outliers in the original plot. To expand the cluster of other localities, these two were dropped, taking the locality total down to 16 , with 13 in the western portion of the study area. By discarding the two outliers, relationships among the main group of localities (Fig. 1.5) became more clear. The three eastern localities separate themselves from the western localities. This separation suggests that there was a difference, even if it was slight, between the crinoids in the shallower and deeper waters of the Lake Valley Formation.

The crinoids unique to the eastern localities make up a very small percentage of the total number of crinoids from the Lake Valley. The most abundant of these is Abatocrinus clypeatus (Hall, 1859) with four specimens. The genus Abatocrinus (A. clypeatus along with A. aequalis 
(Hall, 1858)) only occurs in the deeper water setting. Most species unique to the east;

Cactocrinus multibrachiatus (Hall, 1858), Eutrochocrinus lovei (Wachsmuth and Springer, 1881), Agaricocrinus bullatus Hall, 1858, Agaricocrinus alamogordoensis n sp., and Oenochoacrinus cortina (Miller and Gurley, 1894); are each known only by a single specimen. Platycrinites burlingtonensis (Owen and Shumard, 1850) is represented by three specimens. There are three specimens (Uperocrinus sp., Dichocrinus sp., and Strimplecrinus sp.) that are poorly preserved making it possible that these species may occur in other areas of the Lake Valley Formation. However, when these three specimens are removed from the data there is no significant difference in the MDS distribution of the localities.

Considering the large number of specimens collected and studied from the western part of the formation, it is likely that these few species from the east preferred a different habitat. The quieter waters may have been favored by these species, or they thrived better away from competition of the shallow water environment. Preservation of the crinoids is probably not an issue because the Indian Wells Canyon specimens are the most fragile of all collecting localities. With Indian Wells Canyon having the most fragile and yet the highest number of species unique to the east, it is doubtful that this is a taphonomic artifact where these species were just not preserved in the western region of the study area.

\section{SYSTEMATIC PALEONTOLOGY}

Terminology follows Ubaghs (1978). Materials examined are identified as follows: All M localities were collected by Dr. Macurda and his students in the 1960s and 1970s for the 
University of Michigan. Indiana University specimens were part of the borrowed Macurda collection, collected by A. S. Horowitz and J. H. Johnson. These specimens will remain with the Macurda collection to be housed at the University of Michigan. A few USNM specimens were also part of the borrowed Macurda collection and will be returned to the United States National Museum of Natural History in Washington, D.C. once this study is complete. The USNM numbers associated with the genus Nunnacrinus are housed in the Springer Collection at the Smithsonian. Kues specimens were those collected by Dr. Barry Kues at the University of New Mexico that he was kind enough to allow to be studied and will be returned to him at the conclusion of this study. Laudon specimens are those collected by Dr. Lowell Laudon and are on loan from the University of New Mexico. Those specimens collected in the field by the authors in 2009 are labeled FC (for Field Collection) and will be sent with the Michigan samples. UMMP numbers are those from the University of Michigan that have been assigned to holotypes, paratypes, and all illustrated specimens.

The number of specimens associated with each locality number is indicated . Specimen numbers are represented after the number by $(\mathrm{xN})$ where $\mathrm{N}$ is equal to the number of specimens.

Occurrence information includes the 18 localities used for the faunal analysis information as well as formation and state names for the species that occur outside of the Lake Valley Formation (Table 1.1). For more details on locality information, see Webster's Index (2003). Synonymies (except where noted) are from Webster (2003).

Class Crinoidea Miller, 1821

Subclass Camerata Wachsmuth and Springer, 1885 
Order Diplobathrida Moore and Laudon, 1943

Suborder EudiPLOBathrina Ubaghs, 1953

Superfamily RHODOCRINITACEA Roemer, 1855

Family RHODOCRINITIDAE Roemer, 1855

Genus RHodocrinites Miller, 1821

Type species.—Rhodocrinites verus Miller, 1821; by subsequent designation (Roemer, 1855).

Diagnosis.-Calyx low globe, sides nearly vertical or diverging upward, plates typically have stellate ornamentation; base flattened or concave; basals large; radials commonly smaller than basals, larger than primibrachials; one fixed secundibrachial, rarely more, in each ray; interradial areas large, in contact with tegmen; CD interray wider than others; tegmen flat, composed of many small plates; anal tube short, eccentric.

\section{RHODOCRINITES TUBERCULATUS (Wachsmuth and Springer, 1897)}

Figure 1.7.1-1.7.2

Rhodocrinus tuberculatus Wachsmuth and Springer, 1897, p. 232, pl. 13, figs. 3-4; Miller, S. A., 1897, p. 752; WeLLER, 1898, p. 528.

Rhodocrinites tuberculatus (Wachsmuth and Springer, 1897). BAssLer AND Moodey, 1943, p. 665;

Moore and Laudon, 1944, p. 185, pl. 73, fig. 6; Webster, 1973, p. 232; Webster, 2003.

Diagnosis.—Basals smaller than radials; radials large with long tubercles directed obliquely downward; primibrachials large; tegmen plates large and irregularly arranged. 
Material examined.-M-7(1966) (x1), M-17 (x1), M-80(1971) (x1), M-87 (x1), M-94 (x1), Kues1 (x1), Indiana University 10565 (x3), and USNM 6408 (x1).

Discussion.-_Rhodocrinites tuberculatus is similar to another species reported from the Nunn Member, $R$. barrisi divergens (Hall, 1861a). The differences between the two species are that $R$. tuberculatus has larger radials than basals, and distinct nodes extend from the radials. The basals are larger and contain the large nodes in R. barrisi divergens. The best taxonomic reference for R. tuberculatus is Wachsmuth and Springer (1897).

Occurrence.-Indian Wells Canyon, Black Range undefined, Apache Hill, and North Hollow Creek.

\section{Genus Cribanocrinus Kirk, 1944}

Type species.-_Rhodocrinus wortheni Hall, 1858; by original designation.

Diagnosis.-Calyx medium globe to bowl-shaped, constricted at arm level; base flattened or depressed; basals and radials large compared to primibrachials; one or two fixed secundibrachials in each half-ray; interradial areas narrow and constricted at arm level; CD interray wider than regular interrays; tegmen small, convex, made up of small plates; anus small, either marginal or eccentric, may be protuberant.

Cribanocrinus urceolatus (Wachsmuth and Springer, 1897)

Figure 1.7.3-1.7.4

Rhodocrinus wortheni var. urceolatus WACHSMUtH AND SpRInger, 1897, p. 221, pl. 12, figs. 8a-8b. Miller, S. A., 1897, p. 752; Weller, 1898, p. 529. 
Rhodocrinites wortheni urceolatus (Wachsmuth and Springer, 1897). BAssLeR AND Moodey, 1943, p. 666.

Cribanocrinus urceolatus (Wachsmuth and Springer, 1897). KIRK, 1944, p. 15; BROWER, 1970, p. 488, figs. 79C-79D, pl. 67, figs. 3-4; Webster, 1973, p. 87; Webster, 1977, p. 59; Ubaghs in Moore and Teichert, 1978, p. T425, fig. 233, nos. 3c-3d; WeBster, 1986, p. 106; WebSTer, 2003.

Diagnosis.—Calyx urn-shaped; tegmen flat; anus subcentral, not protuberant Material examined.-M-13 (x5), M-15 (x43), M-16 (x1), M-17 (x50), M-19 (x6), M-91 (x4), M-92 (x3), M-94 (x1), M-95 (x4), M-100 (x1), M-150 (x1), M-153 (x1), M-154 (x1), M-158 (x7), FC14 (x4), Indiana University 10565 (x28), USNM 6408 (x13), and an unknown locality $(\mathrm{x} 2)$

Discussion.-Cribanocrinus urceolatus is similar to the type species $C$. wortheni but is distinguished by being more globe-shaped than bowl-shaped and having a wider tegmen with fewer plates. The best taxonomic references for $C$. urceolatus are Wachsmuth and Springer (1897) and Brower (1970).

Occurrence.-Tierra Blanca Mountain, Black Range undefined, Rock Springs, Apache Hill, between North Percha Creek and Mineral Creek, North Hollow Creek, Percha Creek Fork, Percha Creek, and 0 (Zero) Bar 0 (Zero) Canyon; and Mooney Falls Member of Redwall Limestone, Arizona (Brower, 1970).

Genus Gilbertsocrinus Philips, 1839

Material examined.-FC1(x1)

Figure 1.7.5 
Discussion.-Gilbertsocrinus is questionably assigned to one specimen. Only a partial tegmen is preserved, but the plates have the ornamentation and arrangement consistent with Gilbertsocrinus. There are also features that may be the bases of the tubular tegmen appendages for which the genus is known for.

Occurrence.-North Percha Creek.

Order Monobathrida Moore and Laudon, 1943

Suborder Compsocrinina Ubaghs, 1978

Superfamily Periechocrinacea Bronn, 1849

Family Periechocrinidae Bronn, 1849

Genus Aryballocrinus Breimer, 1962

Type species.—Actinocrinus (Megistocrinus) whitei Hall, 1861; by original designation.

Diagnosis.—Calyx low to medium bowl, with thin plates; radials high; primibrachials, two, first about half size of radial and hexagonal, second smaller than first, pentagonal and axillary; median ray ridges present in some species; one or two secundibrachials fixed in calyx; interbrachials 1-3 in regular interray with three ranges, not depressed; CD interray very wide; tegmen low; anus eccentric.

Aryballocrinus whitei (Hall, 1861a)

Figure 1.7.8-1.7.9

Actinocrinus (Megistocrinus) whitei Hall, 1861a, p. 271 (part); Hall, 1861b, p. 271 (part); Hall, 1861c, p. 271 (part); SHumard, 1868, p. 350; HaLl, 1872b, pl. 4, figs. 4-5 (non fig. 6). 
Actinocrinus whitii Hall, 1861. Miller, S. A., 1889, p. 220 (sic).

Megistocrinus (Saccocrinus) whitei (Hall, 1861). Meek And Worthen, 1873, p. 397, pl. 6, fig. 1. Periechocrinus whitei (Hall, 1861). W achSmuth And Springer, 1881, p. 133 (307); Whitfield, 1893, p. 27, pl. 2, fig. 29.

Periechocrinus? whitei (Hall, 1861). Wachsmuth And Springer, 1897, p. 530, pl. 2, fig. 21; pl. 46, figs. 1-3; pl. 51, figs. 9-10; Grabau and Shimer, 1910, p. 537, fig. 1866.

Periechocrinites whitei (Hall, 1861). Weller, 1898, p. 417; Bassler ANd MoOdey, 1943, p. 601; Moore and Laudon, 1944, p. 189, pl. 75, fig. 14.

Aryballocrinus whitei (Hall, 1861). Breimer, 1962, p. 72; Webster, 1973, p. 59; Ubaghs in Moore and Teichert, 1978, p. T443, fig. 252, no. 1; Lane And Dubar, 1983, p. 117, fig. 3, nos. J, P; Webster, 1986, p. 68; Webster, 1988, p. 40; Webster, 2003.

Actinocrinus olliculus Hall, 1861. Miller, S. A., 1889, p. 219.

Actinocrinus (Megistocrinus) olliculus HaLl, 1861b, p. 2; Weller, 1898, p. 417; Bassler AND Moodey, 1943, p. 601.

Megistocrinus olliculus (Hall, 1861). SHUMARD, 1868, p. 380.

Actinocrinus (Pradocrinus) amplus Meek and Worthen, 1861, p. 133; Weller, 1898, p. 417;

Bassler And Moodey, 1943, p. 601.

Actinocrinus (Pradocrinus?) amplus Meek and Worthen, 1861. Shumard, 1868, p. 342.

Actinocrinus (Saccocrinus?) amplus Meek and Worthen, 1861. Meek And Worthen, 1868b, p. 470, Pl. 16, fig. 2; WeLler, 1898, p. 417.

Actinocrinus amplus Meek and Worthen, 1861. Miller, S. A., 1889, p. 217; Miller, S. A., 1897, p. 730 . 
Saccocrinus amplus (Meek and Worthen, 1861). MilLeR, S. A., 1889, p. 278; Miller, S. A., 1897, p. 752.

Saccocrinus christyi (Hall, 1863). MilLeR, S. A., 1889, p. 278.

Diagnosis.—Calyx plates smooth without ridges along brachials.

Material examined.-M-7(1966) (x1), M-9 (x1), M-15 (x16), M-16 (x1), M-17 (x29), M-19

(x3), M-22 (x11), M-95 (x6), M-158 (x2), FC7 (x1), FC8 (x1), and Laudon 14,030 (x1).

Discussion.-The specimens of Aryballocrinus whitei are identical to those illustrated from the Burlington Limestone. This species is characterized by its lack of ornamentation, having smooth calyx plates where other members of the genus have some form of ridge across the plates. The best taxonomic reference for A. whitei is Wachsmuth and Springer (1897).

Occurrence.-Indian Wells Canyon, Black Range undefined, Rock Springs, Tierra Blanca Mountain, Percha Creek, North Percha Creek, and Wittenberg Ranch Windmill Section; plus Hampton Formation, and lower and upper Burlington Limestone, Iowa.

\section{Aryballocrinus tenuidiscus (Hall, 1861b)}

Figure 1.7.6-1.7.7

Actinocrinus? tenuidiscus Hall, 1861b, p. 14; Shumard, 1868, p. 348; Miller, S. A., 1889, p. 220; WeLLER, 1898, p. 417.

Periechocrinus tenuidiscus (Hall, 1861). WAChSMUtH AND Springer, 1897, p. 520, pls. 46, fig. 4; 51, fig. 6; WeLLER, 1898c, p. 417.

Periechocrinites tenuidiscus (Hall, 1861). Bassler And Moodey, 1943, p. 601. 
Aryballocrinus tenuidiscus (Hall, 1861). BReImer, 1962, p. 73; WeBster, 1973, p. 59; Webster, 2003.

Diagnosis.—Calyx plates ornamented with ill-defined ridges; ridges along brachials more prominent.

Material examined.-M-22 (x1) and M-87 (x1).

Discussion.—Aryballocrinus tenuidiscus is very similar to the Kinderhookian A. sampsoni (Miller and Gurley, 1896) but has a different plate arrangement in the CD interray. Aryballocrinus tenuidiscus has three plates overlying the primanal, followed by two rows of five plates, whereas A. sampsoni has three plates following the primanal with five plates above that, but the outer plates of the third range extend up to the tegmen with several (up to ten) smaller plates between them. The best taxonomic reference for Aryballocrinus tenuidiscus is Wachsmuth and Springer (1897).

Occurrence.-Apache Hill and Rock Springs; lower Burlington Limestone, Iowa.

Family AmpHORACRINIDAE Bather, 1899

Genus AmpHoracrinus Austin, 1848

Type species.—Actinocrinus gilbertsoni Miller in Phillips, 1836; by subsequent designation (Roemer, 1855).

Diagnosis.-Calyx low cone to low bowl; strong calyx lobation; basal circlet low, visible in lateral view; one or two fixed secundibrachials proximal to arm lobe, none in arm lobe; primanal followed by two or three plates; tegmen higher than calyx, medium to high inverted bowl in shape, lobed; five large orals, four forming semicircle around CD oral; anal tube eccentric, 
oriented obliquely upward; no long distal tegmen spines, but short spines ranging to nodes may exist.

AmPHORACRINUS RUPINUs Webster and Lane, 1987

Figure 1.8.1-1.8.2

Amphoracrinus rupinus Webster and Lane, 1987, p. 10, fig. 5, nos. 3-7; Webster, 1993, p. 24;

Webster, 2003; Ausich And Kammer, 2008, p. 1142.

Diagnosis._Calyx low bowl; primanal followed by three plates.

Material examined.-M-15, M-17 (x2), M-19 (x2), M-22, M-95, and an unknown locality.

Discussion.-The specimens examined are in varying states of preservation, with most lacking tegmens. However, there are enough characteristics to confidently assign these specimens to this species.

Occurrence.-Black Range, Rock Springs, and Tierra Blanca Mountain; and Anchor Limestone, Nevada.

Genus Ancalocrinus Webster and Lane, 1987

Type species.-Actinocrinus spinobrachiatus Hall, 1859; by original designation

Diagnosis.-Calyx flat cone, distinctly lobed; basal circlet low, not visible in lateral view; one fixed secundibrachial in calyx; primanal followed by two plates; tegmen much higher than calyx, low to medium bowl in shape, not lobed; five large orals, four forming semicircle around CD oral; anal tube eccentric, oriented obliquely upward; long distal tegmen spines. 
ANCALOCRINUS SPINOBRACHIATUS (Hall, 1859)

Figure 1.8.3-1.8.4

Actinocrinus spinobrachiatus Hall, 1859, p. 6, fig. 6; Shumard, 1868, p. 348.

Amphoracrinus? spinobrachiatus (Hall, 1859). Meek and Worthen, 1873, p. 389, pl. 6, figs. 5a-

5c; WachSMUth AND Springer, 1897, p. 591, pl. 62, figs. 1-4.

Amphoracrinus spinobrachiatus (Hall, 1859). MiLleR, S. A., 1889, p. 223; WelLeR, 1898, p. 83;

Grabau and Shimer, 1910, p. 527, fig. 1854.

Ancalocrinus spinobrachiatus (Hall, 1859). WeBster and LANe, 1987, p. 17, fig. 7, nos. 11-13;

Webster, 1993, p. 25; Webster, 2003; Ausich and Kammer, 2008, p. 1144, fig. 2, nos. 1-3, 5, 6.

Actinocrinus inflatus Hall, 1859, p. 20, unnumbered fig.; Shumard, 1868, p. 344.

Amphoracrinus inflatus (Hall, 1859). Miller, S. A., 1889, p. 223; Whitfield, 1893, p. 22, pl. 2,

figs. 10-11; Miller, S. A., 1897, p. 734; Weller, 1898, p. 83; Bassler and Moodey, 1943, p. 300.

Diagnosis.—See genus description.

Material examined.-M-13 (x4), M-15 (x21), M-17 (x2), M-18 (x1), M-19 (x2), M-22 (x37), M-87 (x3), M-91 (x2), M-92 (x1), M-94 (x1), M-95 (x7), M-99 (x1), M-100 (x3), M-101 (x1), M-158 (x1), Indiana University 10565 (x8), and an unknown locality (x1).

Discussion.-Ancalocrinus spinobrachiatus has been described on either side of the Lake Valley Formation, both to the east in the Burlington Limestone and to the west in the Anchor Limestone. Its occurrence in the Nunn Member fills in a geographic gap between the 
aforementioned formations. The best taxonomic reference for $A$. spinobrachiatus is Wachsmuth and Springer (1897).

Occurrence.-Tierra Blanca Mountain, Black Range, Rock Springs, Apache Hill, between North Percha Creek and Mineral Cree, North Hollow Creek, Percha Creek Fork, and Cooks Range; lower Burlington Limestone, Iowa; and Anchor Limestone, Nevada.

ANCALOCRINUS SP.

Figure 1.8.5-1.8.6

Material examined.-M-86.

Discussion.-This specimen does not have a complete tegmen, making a full comparison to Ancalocrinus spinobrachiatus impossible, but differs by having the basals visible in side view. This may be a variation of A. spinobrachiatus.

Occurrence.-Apache Hill.

Genus Displodocrinus Webster and Lane, 1987

Type species.—Actinocrinus divergens Hall, 1859; by original designation.

Diagnosis. - Calyx flat cone to flat bowl, strongly lobate; basal circlet flat, not visible in lateral view; fixed secundibrachial in arm lobe, none in calyx; primanal followed by three plates; tegmen higher than calyx, high cone to high inverted bowl in shape, not lobed; five large orals, four spinose orals forming semicircle around CD oral; anal tube eccentric, oriented obliquely upward; long distal tegmen spines. 
DisPlodocRINUS DIVERGENS (Hall, 1859)

Figure 1.8.7-1.8.8

Actinocrinus divergens Hall, 1859, p. 36; ShUmaRD, 1868, p. 343.

Amphoracrinus divergens (Hall, 1859). Meek and Worthen, 1868a, p. 348; Meek and Worthen, 1873, p. 388, pl. 6, fig. 6; Miller, S. A., 1889, p. 223; Whitfield, 1893, p. 21, pl. 2, figs. 1213; Keyes, 1894, p. 166, pl. 22, fig. 4; Wachsmuth And Springer, 1897, p. 588, pl. 62, figs. 510; Weller, 1898, p. 82; Grabau and Shimer, 1910, p. 527, fig. 1853; Bassler and Moodey, 1943, p. 299; Moore and Laudon, 1943, p. 139, pl. 10, fig. 13; Moore and Laudon, 1944, p. 191, pl. 77, fig. 28; Webster, 1973, p. 50.

Dispolodocrinus divergens (Hall, 1859). Webster and Lane, 1987, p. 25; Webster, 1993, p. 52;

Webster, 2003; Ausich and Kammer, 2008, p. 1146, fig. 3.1-3.7.

Amphoracrinus divergens var. multiramosus WACHSMUtH AND SPRINGER, 1897, p. 588; WeLLeR, 1898, p. 82; Bassler ANd Moodey, 1943, p. 299.

Actinocrinus planobasalis Hall, 1859, p. 1; Shumard, 1868, p. 347; Hall, 1872b, pl. 4, figs. 1011; Miller, S. A., 1889, p. 219; Weller, 1898, p. 82; Bassler and Moodey, 1943, p. 299. Amphoracrinus planobasalis (Hall, 1859). Meek and Worthen, 1868a, p. 348; Miller, S. A., 1889, p. 223; Miller, S. A., 1897, p. 734; Bassler and Moodey, 1943, p. 299.

Actinocrinus quadrispinus White, C. A., 1862 (adv. pub.); White, C. A., 1865, p. 15; Shumard, 1868, p. 347; Miller, S. A., 1889, p. 219; Weller, 1898, p. 82; Bassler and Moodey, 1943, p. 299; Webster AND LANe, 1987, p. 25.

?Actinocrinus quadrispinus White, 1862; Webster and Lane, 1987, p. 25; Webster, 1993, p. 52. 
Amphoracrinus quadrispinus (White, 1862). Miller, S. A., 1889, p. 223; Wachsmuth AND

SpRINGER, 1889, pl. 18, fig. 13.

Diagnosis.—Calyx flat bowl; basals not visible in lateral view.

Material examined.—M-7 (1966) (x1), M-13 (x1), M-15 (x5), M-17 (x8), M-19 (x5), M-22

(x9), M-91 (x2), M-92 (x1), M-95 (x5), Kues1 (x1), Indiana University 10565 (x1), Unknown locality (x1), Laudon 13,567 (x1), and Laudon 13,905 (x2).

Discussion.-Displodocrinus divergens is different from the other two species of the genus, D. nevadensis (Webster and Lane, 1987) and D. monticulus Webster and Lane, 1987 by having a basal circlet that is not visible in lateral view. The basal circlet of $D$. divergens is flat and not projecting outward. The best taxonomic reference for $D$. divergens is Wachsmuth and Springer (1897).

Occurrence.-Indian Wells Canyon, Marble Canyon, Tierra Blanca Mountain, Black Range, Rock Springs, between North Percha Creek and Mineral Creek, Apache Hill, and Wittenberg Ranch Windmill Section; lower Burlington Limestone, Iowa; Anchor Limestone, Nevada; and Cuyahoga Formation, Ohio.

DisPlodocrinus neVADEnsis (Webster and Lane, 1987)

Figure 1.8.9-1.8.10

Sunwaptacrinus nevadensis WeBster and LANE, 1987, p. 22, fig. 7, nos. 1-5; Webster, 1993, p. 114; WeBster, 2003.

Displodocrinus nevadensis (Webster and Lane, 1987). Ausich and Kammer, 2008, p. 1146.

Diagnosis.—Calyx low bowl; basals visible in lateral view 


\section{Material examined.-M-17 (x1).}

Discussion.—Displodocrinus nevadensis is similar to D. monticulus in that both have a low bowl-shaped calyx with basals visible in lateral view. However, the radials and primibrachials of D. nevadensis are much wider than high than those of D. monticulus.

Occurrence.—Black Range; and Anchor Limestone, Nevada.

Family Actinocrinitidae Austin and Austin, 1842

Subfamily Actinocrinitinae Austin and Austin, 1842

Genus Aacocrinus Bowsher, 1955

Type species._Aacocrinus nododorsatus Bowsher, 1955; by original designation.

Diagnosis.—Calyx medium bowl to medium cone; basal circlet low; radial circlet high; one or two fixed secundibrachials; arms grouped; arm lobes short, extend laterally; interrays in contact with tegmen; no fixed interradials between half-rays; tegmen low arched, lower than calyx; anal tube eccentric; few, large tegmen plates; no tegmen spines; interradial regions of tegmen not depressed.

\section{AaCoCRinus NODODORSATUs Bowsher, 1955}

Figure 1.9.1-1.9.2

Aacocrinus nododorsatus Bowsher, 1955, p. 5, pl. 1, figs. 2-3; figs. 1-2; BRower, 1967, p. 685, pl. 76, figs. 12, 15-16; figs. 1, nos. A, D; 3, no. A; Webster, 1973, p. 29; Ubaghs in Moore and Teichert, 1978, p. T169, Fig. 140, no. 4; Bowsher in Moore and Teichert, 1978, p. T455, Fig. 262, no. 1; Webster, 1986, p. 40; WeBster, 2003. 
Diagnosis. - Calyx cone-shaped; two arm facets to each ray; interradial areas wide; tegmen plates few, large, nodose.

Material examined.-Indiana University 10565 (x1).

Discussion.-Although this is a species thus far known only from the Kinderhookian, the description of Aacocrinus nododorsatus best fits one of the specimens of Aacocrinus from the Nunn Member.

Occurrence._Apache Hill; and Chouteau Limestone, Compton Limestone, Missouri.

Aacocrinus enigmaticus Webster and Lane, 1987

Figure 1.9.3-1.9.4

Aacocrinus enigmaticus Webster and Lane, 1987, p. 15, fig. 5, nos. 12-16; Webster, 1993, p. 19;

WEBSter, 2003.

Diagnosis.—Calyx bowl-shaped; two arm facets to each ray; interradial areas not wide; tegmen plates many, small to medium, nodose.

Material examined.-Indiana University 10565 (x2).

Discussion.-Although Aacocrinus typically has large plates on the tegmen and A. enigmaticus has tegmen plates that are small to medium, the rest of the characters agree with the genus. Webster and Lane (1987, p. 15) discuseds the differences between this species and the rest of the genus and why they place this species in this genus.

Occurrence._Apache Hill; and Anchor Limestone, Nevada.

Genus Blairocrinus Miller, 1891 
Type species.—Blairocrinus trijugis Miller, 1891; by original designation.

Diagnosis.—Calyx low cone; basals low, form flattened disc; one fixed secundibrachial; arms grouped; arm lobes short, extend laterally; interrays in contact with tegmen; no fixed interradials between half-rays; tegmen higher than calyx; anal tube central; tegmen commonly composed of few large plates; proximal tegmen spines; interradial regions of tegmen not depressed.

\section{BLAIROCRINUS MACURDAI n. sp.}

Figure 1.9.5-1.9.6, Table 1.2

Diagnosis.—Arm lobes not protuberant; many medium-sized tegmen plates; tegmen plates spinose to nodose

Description.—Calyx small, low bowl. Arms moderately grouped. Calyx plates with multiple radiating ridges. Basal circlet 11 percent of calyx height. Basals small, three, equal in size. Radial circlet 40 percent of calyx height. Radials hexagonal, wider than high. Tegmen higher than calyx; conical. Tegmen composed of many medium to small spinose to nodose plates. Anal tube central to eccentric. Primanal hexagonal, smaller than radials, followed by 2,3,2,2 plates. Interrays in contact with tegmen. First interradial hexagonal, followed by two plates. First primibrachial hexagonal, wider than high. Second primibrachial axillary, supporting two arm facets each.

Material examined._UMMP 74065 (holotype); UMMP 74066, UMMP 740067 (paratypes);

M-9 (x1), M-15 (x1), M-19 (x1), M-22 (x2), M-80(1971) (x1), M-92 (x1), M-94 (x1), M-95 (x3), M-101 (x1), M-158 (x1). 
Discussion.-Blairocrinus macurdai n. sp. is most similar to B. arrosus Miller, 1892 (Table 1.3); however, the arm rays are not as protuberant as they are in B. arrosus. The ratio is determined by taking the measurements from center of the calyx to the edge of the interbrachial depression and from the center of the calyx to the edge of the ray. For B. macurdai this ratio is from 1.05 to 1.30, whereas in B. arrosus the ratio is 1.26 to 1.30 (Fig. 1.9). Blairocrinus arrosus has a much more constrained range than B. macurdai. There is only slight overlap between the two species, with B. macurdai generally having lower ratios and, therefore, having less protuberant arm rays.

Occurrence.-Indian Wells Canyon, Black Range undefined, Rock Springs, Apache Hill, North Hollow Creek, Tierra Blanca Mountain, Percha Creek, Percha Creek Fork, and Wilson’s Ranch.

Etymology.-The trivial name recognizes Dr. Brad Macurda who collected most of the studied specimens during the 1960's and 1970's.

Genus IotaCRINus Ausich and Sevastopulo, 2001

Type species. - Actinocrinus dorsatus de Koninck and LeHon, 1854; by original designation. Diagnosis.—Calyx low bowl; basals low; one fixed secundibrachial; arms grouped; arm lobes medium in length, extend laterally; interrays in contact with tegmen; no fixed interradials between half-rays; calyx as high or higher than tegmen; anal tube eccentric; many medium-size tegmen plates; no tegmen spines; interradial regions of tegmen not depressed. 
Discussion.- The occurrence of Iotacrinus in the Lake Valley Formation is the first recorded finding of Iotacrinus in North America. Other members of this genus are known only from Western Europe.

IOTACRINUS NOVAMEXICANA n. sp.

Figure 1.9.7-1.9.8, Table 1.4

Diagnosis.—Calyx low to medium bowl; tegmen as high or slightly higher than calyx.

Description.-Calyx small, low bowl. Arms strongly grouped, extended into short arm lobes. Calyx plates with multiple radiating ridges. Basals small, three, equal in size. Basal circlet accounts for 10 percent of calyx height. Radial circlet is 35 percent of calyx height. Radials hexagonal, wider than high. Tegmen as high or slightly higher than calyx, lobed, inflated. Tegmen plates are numerous, medium in size, smooth to slightly nodose. Anal tube eccentric. Primanal hexagonal, slightly narrower than radials, followed by 2,3 plate formula. Interrays in contact with tegmen. First interradial hexagonal, followed by two plates. First primibrachial hexagonal, wider than high. Second primibrachial axillary, supporting one arm facet each. Arms and column not known.

Material examined._UMMP 74068 (holotype); UMMP 74069, UMMP 74070 (paratypes); M-15 (x2), M-16 (x1), M-158 (x1), and Indiana University 10565 (x1).

Discussion.-Iotacrinus novamexicana shares characters of both actinocrinitids and amphoracrinidids. The calyx is undoubtedly of the actinocrinitid family based on shape, plates, and ornamentation, but the tegmen more closely resembles Amphoracrinus than any other known North American actinocrinitid. Iotacrinus novamexicana somewhat resembles the type species I. 
dorsatus (Table 1.5), but the tegmen is much higher and more distinctly lobed, like the tegmens of Amphoracrinus.

One specimen has a higher calyx that is more conical than bowl shaped, but the other features remain constant to the species. Therefore, this specimen is considered to be a variation and not a separate species.

Occurrence.—Black Range undefined, Apache Hill, and Percha Creek.

Etymology.-The trivial name recognizes the state of New Mexico.

Genus Steganocrinus Meek and Worthen, 1866

Type species.-Actinocrinus pentagonus Hall, 1858; by original designation.

Diagnosis.—Calyx medium cone; basal circlet low or high; radials high; primibrachial highest fixed brachial; arms grouped; interrays in contact with tegmen; fixed interbrachials between half-rays; tegmen flat to low arched to same height as calyx, composed of few, large plates; anal tube eccentric.

Steganocrinus PENTAGonus (Hall, 1858)

Figure 1.9.9-1.8.10

Actinocrinus pentagonus Hall, 1858, p. 577, pl. 10, figs. 6a-6b; Shumard, 1868, p. 346; Miller, S. A., 1889, p. 219; WelleR, 1898, p. 600.

Steganocrinus pentagonus (Hall, 1858). Meek and Worthen, 1866, p. 254; Meek and Worthen, 1868b, p. 474, pl. 16, fig. 8; Miller, S. A., 1889, p. 282, fig. 430; Keyes, 1894, p. 195, pl. 24, fig. 9; Wachsmuth and Springer, 1897, p. 579, pls. 4, fig. 12; 61, figs. 3a-4b; Weller, 
1898, p. 600; Grabau and Shimer, 1910, p. 529; Wilson, H. E., 1916, p. 509, pl. 3, figs. 1-3; Kirk, 1943, p. 261, figs. 1-2; Bassler and Moodey, 1943, p. 683; Moore and Laudon, 1943, p. 139, pl. 10, fig. 12; Moore and Laudon 1944, p. 193, pl. 77, fig. 6; Laudon, 1948, pl. 3; Spreng and Parks, 1953, p. 594, fig. 1, nos. f-h; Brower, 1965, p. 776, pl. 91, figs. 1-15; pl. 92, figs. 1-37; fig. 1; BROwer, 1967, p. 683, pl. 76, fig. 9; BROWER, 1970, p 494, pl. 64, figs. 6, 10, 13; fig. 80, nos. B-D; Laudon, 1973, p. 29, fig. 5; Haugh, 1973, p. 90, pl. 3, fig. 3; Webster, 1973, p. 242; Haugh, 1975b, p. 267, fig. 4, no. C; Webster, 1977, p. 158; Ubaghs in Moore and Teichert, 1978a, p. T144, T179, T194, fig. 116, no. 3; fig. 151, no. 5; fig. 164, no. 3; Bowsher in Moore and Teichert, 1978, p. T455, fig. 263, no. 4; Webster, 1986, p. 288; WEBSTER, 2003.

Actinocrinus araneolus Meek and Worthen, 1860, p. 387; Shumard, 1868, p. 342; Miller, S. A., 1889, p. 217; WeLLER, 1898, p. 599.

Steganocrinus araneolus (Meek and Worthen, 1860). Meek And Worthen, 1866a, p. 198, pl. 15, figs. 1a-1b; Miller, S. A., 1889, p. 282; Wachsmuth and Springer, 1897, p. 581, pl. 61, figs. 2a-2b; Weller, 1898, p. 599; Grabau and Shimer, 1910, p. 528; Kirk, 1943, p. 260, fig. 4; Bassler and Moodey, 1943, p. 683; Brower, 1965, p. 776; Laudon, 1973, p. 29, fig. 5; WeBster, 1973, p. 242.

Steganocrinus arraneolus (Meek and Worthen, 1860) (sic). WeBsTer, 1977, p. 157.

Diagnosis.-Calyx medium cone and constricted above basals; plates strongly to weakly stellate, nodose or weakly tumid; basal circlet high; tegmen low arched.

Material examined.-M-5 (x2), M-6 (x6), M-7(1966) (x3), M-7(1972) (x3), M-9 (x1), M-13 (x32), M-15 (x323), M-16 (x6), M-17 (x267), M-18 (x5), M-19 (x52), M-21 (x2), M-22 (x90), 
M-73 (x3), M-80 (x6), M-86 (x8), M-87 (x21), M-91 (x52), M-92 (x20), M-93 (x5), M-94 (x51), M-95 (x154), M-98 (x5), M-100 (x17), M-101 (x2), M-102 (x1), M-151 (x8), M-153 (x1), M154 (x7), M-155 (x4), M-157 (x1), M-158 (x34), M-159 (x2), Barry2 (x1), FC2 (x2), FC9 (x2), Indiana University 10565 (x113), an unknown locality (x3), USNM 6408 (x1), USNM (x6), Laudon 14,031 (x6), Laudon 14,062 (x1), Laudon 13,918 (x15), Laudon 13,999 (x1), Laudon 14,022 (x10), and Laudon 13,567 (x2).

Discussion.-Steganocrinus pentagonus is the most abundant crinoid in the Nunn Member. The numerous specimens have the full range of variation found within the species. While most of the specimens are undoubtedly $S$. pentagonus, there are a handful of specimens that fall into the range of two other species: S. altus Brower, 1965 and S. longus Brower, 1965.

Brower (1965) stated that Steganocrinus altus is distinguished from S. pentagonus by having a more conical calyx, but all other aspects of $S$. altus are the same as $S$. pentagonus. The illustration of the paratype for S. altus (Brower, 1965, pl. 93, fig. 7) is identical to an illustrated S. pentagonus (Brower, 1965, pl. 92, fig. 29). Similarly, S. longus differs in shape of the calyx from S. pentagonus. The calyx of S. longus is more box-like and less cone-shape than $S$. pentagonus. Brower (1965) stated that S. longus also has calyx plates that are highly tumid as well as high ambulacral tracts. These two characteristics occur in S. pentagonus as well. It is possible that these two species are variations within the total range of $S$. pentagonus, but until further studies can be done, they will remain as separate species. The best taxonomic reference for S. pentagonus is Brower (1965).

Occurrence.-Indian Wells Canyon, Marble Canyon, San Andres Canyon, Trujillo Creek, Black Range undefined, Tierra Blanca Mountain, Rock Springs, Apache Hill, between North 
Percha Creek and Mineral Creek, Percha Creek Fork, Percha Creek, North Percha Creek, 0 Bar 0 Canyon, Wittenberg Ranch Windmill Section, and Cooks Range; lower Burlington Limestone, Iowa; and Fern Glen Limestone, Missouri.

\section{Subfamily CACTOCRINIAE Ubaghs, 1978}

Genus CaCtocrinus Wachsmuth and Springer, 1897

Type species.—Actinocrinus proboscidialis Hall, 1858; by original designation.

Diagnosis.-Calyx medium cone; basal circlet low; radials low; one fixed secundibrachial; arms not grouped; arm lobes absent; four to eight arms in each ray; interrays not in contact with tegmen; fixed interradials between half-rays present; tegmen and calyx approximately same height; anal tube central.

\section{CACTOCRINUS PROBOSCIDIALIS (Hall, 1858)}

Figure 1.11.1-1.11.2

Actinocrinus proboscidialis Hall, 1858, p. 584, pl. 10, fig. 13; Hall, 1859, pl. 3, fig. 2; SHUMARD, 1868, p. 347; Meek and Worthen, 1869, p. 440; Meek and Worthen, 1873, p. 328, pl. 9, figs. 7a-7c, ?8a-8b; ZitTel, 1880, p. 334, 369, figs. 229, 257, nos. a-d; Miluer, S. A., 1889, p. 219, fig. 234; Neumayr, 1889, p. 465, fig. 135; Keyes, 1890, pl. 8, fig. 2; Steinmann and Döderlein, 1890, p. 153, figs. 156, nos. B-C; 157, nos. B-C; Keyes, 1894, p. 185, pl. 20, fig. 2; pl. 24, fig. 1; Lahusen, 1895, p. 140, fig. 189, nos. a-c; Zittel, 1895, p. 119, 128, fig. 232, nos. A-C; fig. 246, nos. A-D; Miller, S. A., 1897, p. 731; Weller, 1898, p. 156; Wachsmuth in Zittel, 1900, p. 124, 142, figs. 220, 232, 243, no. A; Steinmann, 1903, p. 177, fig. 246, nos. B-C; 
Steinmann, 1907, p. 189, fig. 281, nos. B-C; Bassler, 1938, p. 55; Bassler and Moodey, 1943, p. 343.

Actinocrinus (Cactocrinus) proboscidialis Hall, 1858; Steinmann, 1907, p. 189, fig. 267, nos. BC.

Cactocrinus proboscidialis (Hall, 1858). WACHSMUtH AND SpRinger, 1897, p. 601, pl. 5, fig. 10; pl. 58, figs. 3-7d; Weller, 1898, p. 156; Bather in Lankester, 1900, p. 129, fig. 44; GraBAU AND ShImer, 1910, p. 526, figs. 1805, 1851; KIRK, 1911, pl. 5, figs. 4-5; SpRINGER in Zittel, 1913, p. 174, figs. 268, 280, 299-A; Moore, 1939, p. 243, fig. 13, no. 2; BAssler And Moodey, 1943, p. 343; Moore And Laudon, 1944, p. 191, pl. 77, fig. 3; Webster, 1973, p. 72; Haugh, 1975a, p. 476, pl. 1, fig. 3; UbaGHs in Moore and Teichert, 1978, p. T154, T179, fig. 127, no. 1; fig. 152, no. 2; Bowsher in Moore and Teichert, 1978, p. T458, fig. 266, nos. 1a-1b; Wolf, 1979, p. 150, fig. 1, nos. g-h; WeBster, 1986, p. 83; Webster, 2003.

Batocrinus proboscidialis (Hall, 1858). MilLer, S. A., 1897, p. 738.

Cactocrinus proboscidalis (Hall, 1858). Sieverts-Doreck, 1952, p. 424, fig. 2; Ubaghs, 1953, p. 739, fig. 22, no. e.

Actinocrinus quaternarius Hald, 1859, p. 22, unnumbered fig; Shumard, 1868, p. 347; WhitfiELd, 1881, p. 7, pl. 1, figs. 1-3; Miller, S. A., 1889, p. 219; Miller, S. A., 1897, p. 731; Weller, 1898, p. 156; Bassler AND Moodey, 1943, p. 343.

Actinocrinus lagena Hald, 1861b, p. 13; Shumard, 1868, p. 345; Miller, S. A., 1889, p. 218;

Wachsmuth And Springer, 1897, p. 453, pl. 35, fig. 4; Weller, 1898, p. 156; Bassler AND MoOdey, 1943, p. 343. 
Actinocrinus quaternarius var. spinigerus Hall, 1861b, p. 11; Shumard, 1868, p. 347; Miller, S.

A., 1889, p. 219; Weller, 1898, p. 156; Bassler and Moodey, 1943, p. 343.

Actinocrinus themis Hall, 1861b, p. 11; Shumard, 1868, p. 349; Miller, S. A., 1889, p. 220;

Bassler and Moodey, 1943, p. 343.

Diagnosis.—Radials wider than long; first primibrachials larger than second; tegmen conical; tegmen about as high as calyx, plates large, spinous or nodose, separated by smaller, convex plates.

Material examined.-M-9 (x1), M-13 (x1), M-19 (x1), M-95 (x1), Laudon 13,998 (x1), and Laudon 13,578 (x2).

Discussion.-The specimens of Cactocrinus proboscidialis in the Nunn Member closely resemble those illustrated from the Burlington Limestone. Calyx plates have variation in ornamentation, ranging from being only slightly nodose to having distinct stellate ornamentation. The C. proboscidialis specimens from the Nunn Member fall between these two extremes. The best taxonomic reference for C. probiscidalis is Wachsmuth and Springer (1897).

Occurrence.-Indian Wells Canyon, Marble Canyon, Tierra Blanca Mountain, Black Range undefined, and Wittenberg Ranch Windmill Section; Chouteau Limestone, Missouri; and lower Burlington Limestone, Iowa.

\section{CACTOCRINUS MULTIBRACHIATUS (Hall, 1858)}

Figure 1.11.3-1.11.4

Actinocrinus multibrachiatus Hall, 1858, p. 580, pl. 10, fig. 10; fig. 85; Shumard, 1868, p. 346;

Miller, S. A., 1889, p. 219; WelleR, 1898, p. 155. 
Cactocrinus multibrachiatus (Hall, 1858). WACHSMUTH AND SPRINGER, 1897, p. 617, pl. 56, figs. 67; pl. 58, fig. 8; Weller, 1898, p. 155; Bassler and Moodey, 1943, p. 342; Moore And Laudon, 1943, p. 140, pl. 11, fig. 1; Moore and Laudon, 1944, p. 191, pl. 77, fig. 2; Webster, 1973, p. 71; Bowsher in Moore and Teichert, 1978, p. T458, fig. 266, no. 1c; WeBster, 1986, p. 82; WeBSTER, 2003.

Actinocrinus multibrachiatus var. echinatus HaLl, 1861b, p. 10; MıLler, S. A., 1889, p. 219;

Weller, 1898, p. 155; Bassler and Moodey, 1943, p. 342.

Diagnosis.—Radials nearly as high as wide; second primibrachials larger than first; tegmen depressed conical; tegmen lower than calyx, plates largest near anal tube smallest near arm bases; nodose.

Material examined.-M-80(1971) (x1).

Discussion.—Although the tegmen is not complete on this specimen, it is evident from the angle of what is preserved that it is much lower than the calyx. The best taxonomic reference for Cactocrinus multibrachiatus is Wachsmuth and Springer (1897).

Occurrence.-Indian Wells Canyon; and lower Burlington Limestone, Iowa.

Genus Cusacrinus Wachsmuth and Springer, 1897

Type species.-Actinocrinus nodobrachiatus Wachsmuth and Springer in Miller, 1889; by original designation.

Diagnosis.—Calyx steeply conical; basal circlet low; radials high; one fixed secundibrachial; arms weakly grouped; arm lobes absent; primanal slightly smaller than radials; interrays in 
contact with tegmen; fixed interradials between half-rays present; tegmen low arched to conical; large plated; anal tube central to subcentral.

CusACrINus sobrinus (Miller and Gurley, 1896c) n. comb.

Figure 1.11.5-1.11.6

Actinocrinus sobrinus Miller and Gurley, 1896c, p. 10, pl. 3, figs. 4-5; Miller, S. A., 1897, p. 731; Weller, 1898, p. 63.

Actinocrinites sobrinus (Miller and Gurley, 1896). Bassler and Moodey, 1943, p. 274; Webster, 2003.

Diagnosis.—Four arms per ray; tegmen depressed, convex, lacking spinose plates; anal tube small, subcentral.

Material examined.-Indiana University 10565 (x1), and an unknown locality (x1).

Discussion.—Actinocrinites sobrinus (Miller \& Gurley, 1896c) is moved to the genus Cusacrinus for a lack of arm lobes, arms that are weakly grouped, and a tegmen that is lower than the calyx. It is conceivable that A. spectabilis (Miller \& Gurley, 1896c) and A. subscitulus (Miller \& Gurley, 1896c) can be synonymized into one species with Cusacrinus sobrinus, but until further investigations can be done, they will remain as separate species.

Occurrence.—Apache Hill; and Burlington Limestone, Iowa.

Cusacrinus tenuisculptus (McChesney, 1861)

Figure 1.11.7-1.11.8 
Actinocrinus tenuisculptus Mcchesney, 1861, p. 15; Mcchesney, 1868, p. 11, pl. 5, figs. 1a-1b; unnumbered fig. p. 12; Miller, S. A., 1889, p. 220; WaChSMuth And Springer, 1897, p. 571, pl. 55, figs. 4a-4b; WeLLER, 1898, p. 64.

Actinocrinites tenuisculptus (McChesney, 1861). Bassler and Moodey, 1943, p. 275; Laudon, 1973, p. 29, Fig. 5.

Cactocrinus tenuisculptus (McChesney, 1861). KIRK, 1943c, p. 346.

Cusacrinus tenuisculptus (McChesney, 1861). Bowsher, 1955, p. 16; WeBster, 1973, p. 94;

WEBSTER, 2003.

Diagnosis.—Six arms per ray; tegmen subpyramidal with spinose plates; anal tube large, central.

Material examined.—M-22 (x1), Indiana University 10565 (x1), and Laudon 14,920 (x1).

Discussion.-Two specimens of Cusacrinus tenuisculptus are known from the Nunn Member collections, and of the two, only one is well preserved. That specimen has only four arms per ray, which contradicts the descriptions of the species that say there are six arms per ray. However, illustrations by Wachsmuth and Springer (1897, pl. 55, figs. 4a-4b) indicate that the armless C. tenuisculptus appears to only have four arms per ray, whereas the armed specimen shows six. The inner arms bifurcate immediately after leaving the calyx, creating the six arms. If the arms break right at the calyx, then it appears that there are only four arms per ray.

It may be possible to synonymize Actinocrinites plagosus (Miller \& Gurley, 1893) with Cusacrinus tenuisculptus. The single illustration and description of A. plagosus is reminiscent of the calyx of C. tenuisculptus. A. plagosus is also lacking a tegmen; and because both species 
occur in the lower Burlington, it is plausible they are the same. But, more work will need to be done before that synonymy can be decided.

Occurrence._- Rock Springs, Apache Hill, and Tierra Blanca Mountain; Chouteau Limestone, Missouri; and Burlington Limestone, Iowa.

Genus Nunnacrinus Bowsher, 1955

Type species.—Nunnacrinus mammillatus Bowsher, 1955; by original designation.

Diagnosis.—Calyx low to medium cone; basal circlet low; radials low; one fixed secundibrachial; arms weakly grouped; interrays in contact with tegmen; fixed interbrachials between half-rays; tegmen low to approximately as high as calyx; anal tube central.

NunNaCRinus dalyanus (Miller, 1881) n. comb.

Figure 1.11.9-1.11.10

Actinocrinus dalyanus Miller, S. A., 1881, p. 309, pl. 7, figs. 1-1a; Miller, S. A., 1889, p. 217;

WeLLeR, 1898, p. 156.

Nunnacrinus dalyanus (Miller, 1881). BowsHeR, 1955, p. 18; WeBSTER, 2003.

Actinocrinus delayanus (Miller, 1881) (sic). Bowsher, 1955, p 18; Webster, 1973, p. 182.

Nunnacrinus delayanus (Miller, 1881). Bowsher, 1955, p. 18 (sic); Webster, 1973, p. 182.

Nunnacrinus mammillatus Bowsher, 1955, p. 19, pl. 3, figs. 6-7; pl. 6, figs. 2-3; fig. 3, nos. A-D;

Webster, 1973, p. 182; Bowsher in Moore and Teichert, 1978, p. T460, fig. 267, no. 2;

Webster, 1986, p. 219; WeBster, 2003.

Diagnosis.—Calyx conical; tegmen as high as calyx, conical. 
Material examined.-M-5 (x2), M-6 (x5), M-7(1966) (x5), M-9 (x2), M-13 (x12), M-15 (x136), M-16 (x7), M-17 (x119), M-18 (x2), M-19 (x37), M-21 (x3), M-22 (x40), M-73 (x2), M80 (x2), M-86 (x6), M-87 (x15), M-91 (x17), M-92 (x13), M-93 (x2), M-94 (x5), M-95 (x73), M-97 (x2), M-99 (x1), M-100 (x8), M-102 (x2), M-151 (x1), M-154 (x1), M-155 (x3), M-158 (x40), M-159 (x2), FC11 (x1), Indiana University 10565 (x61), an unknown locality (x3), USNM 6431 (x1), Laudon 14,042 (x2), Laudon 14,041 (x1), Laudon 14,290 (x2), Laudon 14,022 (x1), Laudon 13,999 (x1), Laudon 13,559 (x1), Laudon 14,077 (x1), Laudon 13,998 (x10), Laudon 13,578 (x4), Laudon 14,028 (x7), and Laudon 13,817 (x2). USNM Specimens: S4622 (x1), S4621 (x1), S4623 (x1), S4619 (x4), S4618 (x10), 435908 (x1), 435904 (x1), 435907 (x1), 435905 (x1), 435906 (x1), 435912 (x1), 160619 (x1), 435910 (x1), 160618 (x1), 435911 (x1), 435923 (x1), 435903 (x1), 435898 (x1), 160604 (x1), 160617 (x1), 435909 (x1), 435895 (x1), 435899 (x1), 435897 (x1), 435900 (x1), 435901 (x1), 448071 (x1), 160602 (x1), 114695 (x1), S4620 (x4), S1218 (x3), 118032 (x1), 118028 (x5), 118030 (x2), 118026 (x2), 118027 (x1), 118029 (x1), and 118031 (x1).

Discussion.-Bowser (1955, p. 20) stated that Nunnacrinus dalyanus and N. mammillatus are readily separable from each other based on the number of plates that separate the rays (one plate and two plates respectively), different sizes, how conical the calyces and tegmens are, and how regular the size of the tegmen plates are. However, after comparing the 663 specimens in the Macurda and Laudon collections, as well as comparing the 61 in the Springer Room of the Smithsonian, it has been determined that the two species are the same. There is no set pattern for the interradial plates between the arm facets, with many having both single and double plates between the rays (Fig. 1.11), and the entire interradial area has a wide variety of plate 
arrangements (Appendix 3). The other ways of supposed easy separation are likewise indistinguishable, showing the range of variability. The best taxonomic reference for $N$. dalyanus is Brower (1955).

The location of the type specimens is not known; and, therefore, a neotype has been established as UMMP 74074 (Fig. 1.10.9-1.10.10).

Occurrence.-Indian Wells Canyon, Marble Canyon, San Andres Canyon, Trujillo Creek, Tierra Blanca Mountain, Black Range undefined, Rock Springs, Apache Hill, between North Percha Creek and Mineral Creek, Percha Creek Fork, Percha Creek, North Hollow Creek, 0 Bar 0 Canyon, Cooks Range, and Wittenberg Ranch Windmill Section.

Genus TeleIOCRINus Wachsmuth and Springer, 1881

Type species.-Actinocrinus umbrosus Hall, 1858; by original designation.

Diagnosis.—Calyx medium cone, plates nodose or stellate; basal circlet high; radial circlet high; one fixed secundibrachial; arms not grouped; arm lobes absent; interrays not in contact with tegmen; fixed interradials between half-rays present; tegmen lower than calyx; anal tube central.

Teleiocrinus umbrosus (Hall, 1858)

Figure 1.13.1-1.13.2

Actinocrinus umbrosus Hall, 1858, p. 590, pl. 11, figs. 3a-3b; fig. 89; Shumard, 1868, p. 349;

Quenstedt, 1876, p. 571, pl. 110, fig. 28; Miller, S. A., 1889, p. 220; Weller, 1898, p. 628. 
Strotocrinus umbrosus (Hall, 1858). MeeK and Worthen, 1873, p. 149 (323); Miller, S. A., 1889, p. 284; Weller, 1898, p. 628.

Teleiocrinus umbrosus (Hall, 1858). WAChSmuth And SpRinger, 1881, p. 149 (323); KeYes, 1890, pl. 8, fig. 4; WachSmUth and Springer, 1897, p. 628, pl. 4, fig. 11; pl. 5, figs. 3-4; pl. 59, fig. 7; pl. 60, figs. 2a-2d; Weller, 1898, p. 628; Grabau and Shimer, 1910, p. 528, fig. 1855; Wilson, H. E., 1916, p. 508, pl. 1, figs. 1-6; Van TuYL, 1925, p. 123, 131, pl. 4, fig. 11; Bassler and Moodey, 1943, p. 707; Moore and Laudon, 1943b, p. 140, pl. 11, fig. 5; Moore and Laudon, 1944, p. 193, pl. 77, fig. 1; Laudon, 1948, pl. 3 (part); Spreng and Parks, 1953, p. 586, fig. 1, no. i; Webster, 1973, p. 255; Macurda, 1974, p. 829; Brower, 1974b, p. 19, fig. 13, nos. 1-3; BuRKe, 1975a, p. 483, pl. 1, fig. 10; pl. 2, fig. 11; pl. 3, fig. 10; WeBster, 1977, p. 167; Ubaghs in Moore and Teichert, 1978, p. T201, fig. 170, no. 2; Brower in Moore and Teichert, 1978, p. T251, fig. 201, nos. 1-3; Bowsher in Moore and Teichert, 1978, p. T460, fig. 268, no. 1; Webster, 1986, p. 301; Webster, 2003.

Actinocrinites umbrosus (Hall, 1858). WelLeR, 1898, p. 628.

Actinocrinites delicatus Meek and Worthen, 1870, p. 156; Meek and Worthen, 1873, p. 343, pl.

8, fig. 2; Meek, 1874, p. 192; Bassler and Moodey, 1943, p. 707.

Actinocrinus delicatus (Meek and Worthen, 1870). Меeк, 1874, p. 192; Miller, S. A., 1889, p. 217; WeLLeR, 1898, p. 628.

Actinocrinus aeglops Hall, 1859, p. 5, unnumbered fig; Weller, 1898, p. 628; BAssLer AND Moodey, 1943, p. 707.

Teleiocrinus aeglops (Hall, 1859). WelLeR, 1898, p. 628; BAssler AND MOOdEy, 1943, p. 707. Teleiocrinus aegilops (Hall, 1859) (sic). Shumard, 1868, p. 341; Miller, S. A., 1889, p. 217, 286. 
Strotocrinus aegilops (Hall, 1859) (sic). MiLler, S. A., 1897, p. 753.

Teleocrinus aegilops (Hall, 1859) (sic). Whitfield, 1893, p. 21, pl. 2, figs. 27-28.

Actinocrinus rudis Hall, 1859a, p. 33; Shumard, 1868, p. 347; Miller, S. A., 1889, p. 219;

Weller, 1898, p. 628; Bassler and Moodey, 1943, p. 707.

Teleiocrinus rudis (Hall, 1859). WACHSMUtH AND SpRINGER, 1881, p. 149 (323), pl. 19, fig. 11;

Miller, S. A., 1889, p. 286; Wachsmuth AND Springer, 1897, p. 630, pl. 5, fig. 1; pl. 59, figs.

1-3; Weller, 1898, p. 628; Bassler and Moodey, 1943, p. 707; Moore and Laudon, 1943b, p.

140, pl. 11, fig. 6; Moore and Laudon, 1944, p. 193, pl. 77, fig. 11; Laudon, 1948, pl. 3 (part);

Webster, 1973, p. 255; Macurda, 1974, p. 829; BurKe, 1975a, p. 483, pl. 1, fig. 5; pl. 5, fig.

9; Haugh, 1975b, p. 269, fig. 5, no. 7; fig. 6, no. 6; fig. 7, no. D; Webster, 1977, p. 167;

Ubaghs in Moore and Teichert, 1978, p. T195, fig. 164, no. 5; Webster, 1986, p. 301.

Teleiocrinus rudis Good, 1968 (non Hall, 1858), pl. 1, fig. 7; WeBSTER, 1977, p. 167.

Actinocrinus clivosus Hall, 1861a, p. 274; Hall, 1861c, p. 274; Shumard, 1868, p. 350; Miller,

S. A., 1889, p. 217; Weller, 1898, p. 628; Bassler and Moodey, 1943, p. 707.

Teleiocrinus clivosus (Hall, 1861). MiLLeR, S. A., 1889, p. 286.

Actinocrinus erodus Hall, 1861. WelLeR, 1898, p. 628.

Actinocrinus (Calathocrinus) erodus Hall, 1861b, p. 12; Shumard, 1868, p. 344; Miller, S. A.,

1889, p. 218; Bassler, 1938, p. 56; Bassler and Moodey, 1943, p. 707.

Teleiocrinus erodus (Hall, 1861). MiLLER, S. A., 1889, p. 286.

Actinocrinus insculptus Hall, 1861. MilleR, S. A., 1889, p. 218; Weller, 1898, p. 628.

Actinocrinus (Calathocrinus) insculptus Hald, 1861b, p. 12; ShUmARD, 1868, p. 344; BASSLER AND Moodey, 1943, p. 707. 
Teleiocrinus insculptus (Hall, 1861). MilLER, S. A., 1889, p. 286.

Diagnosis.—Calyx plates nodose.

Material examined.—Laudon 14,284 (x1).

Discussion.-The occurrence of Teleiocrinus umbrosus in the Lake Valley Formation indicates the species originated earlier than once thought. It has previously been known from the upper Burlington Limestone but not the lower portion, which is correlative with the Nunn Member. The best taxonomic reference for T. umbrosus is Wachsmuth and Springer (1897). Occurrence.-Tierra Blanca Mountain; and upper Burlington Limestone, Iowa.

Subfamily Physetocrininae Ubaghs, 1978

Genus Physetocrinus Meek and Worthen, 1869

Type species.—Actinocrinus ventricosus Hall, 1858; by subsequent designation (Wachsmuth and Springer, 1881).

Diagnosis.—Calyx medium-bowl to medium-cone shape; basal circlet high; radials large; tertibrachial to quartibrachial highest fixed brachials; arms grouped, lobed in early species, less so in later species; interrays in contact with tegmen; fixed intrabrachial between half-rays; tegmen lower than calyx; no anal tube; anal opening eccentric.

Physetocrinus COPeI (Miller, 1881)

Figure 1.13.5-1.13.6

Actinocrinus copei Miller, S. A., 1881, p. 310, pl. 7, figs. 2-2b; WelLeR, 1898, p. 426. 
Physetocrinus copei (Miller, 1881). Miller, S. A., 1889, p. 269, fig. 390; WaChSmuth AND

Springer, 1897, p. 598, pl. 63, fig. 5; Weller, 1898, p. 426; Bassler and Moodey, 1943, p.

610; Brower, 1970, p. 501, pl. 65, figs. 3-4; fig. 82, nos. A-B; Webster, 1977, p. 135;

WEBSTER, 2003.

Diagnosis.—Calyx conical, approximately equidimensional; basals with sutures slightly grooved; tegmen hemispherical, gently convex, not lobate; anal opening elevated slightly above tegmen.

Material examined.-M-5 (x1), M-6 (x7), M-13 (x6), M-15 (x225), M-16 (x5), M-17 (x149), M-18 (x3), M-19 (x30), M-21 (x2), M-22 (x107), M-80 (x3), M-86 (x1), M-87 (x9), M-89 (x1), M-91 (x37), M-92 (x8), M-94 (x14), M-95 (x62), M-98 (x1), M-99 (x3), M-100 (x1), (x6), M101 (x2), M-102 (x2), M-151 (x3), M-152 (x1), M-154 (x1), M-155 (x2), M-158 (x36), M-159 (x1), FC3 (x3), FC6 (x4), Indiana University 10565 (x2), an unknown locality (x5), Laudon 14,061 (x1), Laudon 13,923 (x1), Laudon 13,803 (x10), Laudon 14,062 (x1), Laudon 14,065 (x1), Laudon 14,250 (x9), Laudon 13,619 (x4), Laudon 14,072 (x1), Laudon 14,059 (x1), and Laudon 14,042 (x2).

Discussion.—Physetocrinus copei is one of the most abundant crinoid species in the Nunn Member, second only to Steganocrinus pentagonus based on the collections studied. The number of specimens allow for studying the amount of variation within the species. The tegmen, especially, has a wide range of variation; ranging from slightly convex to rather inflated (Fig. 1.13). Specimens that have inflated tegmens have similarity to P. majusculus Webster and Lane, 1987 but do not have any other significant differences from $P$. copei and should remain as $P$. copei. It may well be that $P$. majusculus is a variation of $P$. copei, but until further investigations 
can be made, the two will remain separate species. The best taxonomic reference for $P$. copei is Wachsmuth and Springer (1897).

Occurrence.-Indian Wells Canyon, Marble Canyon, Grapevine Canyon, Trujillo Creek, Tierra Blanca Mountain, Black Range undefined, Rock Springs, Apache Hill, between North Percha Creek and Mineral Creek, Percha Creek Fork, Percha Creek, North Percha Creek, North Hollow Creek, 0 Bar 0 Canyon, Wittenberg Ranch Windmill Section, and Cooks Range; and Thunder Springs Member or Mooney Falls Member of Redwall Limestone, Arizona.

\section{Physetocrinus lobatus Wachsmuth and Springer, 1897}

Figure 1.13.3-1.13.4

Physetocrinus lobatus Wachsmuth and Springer, 1897, p. 599, pl. 63, figs. 8a-8b; Miller, S. A., 1897, p. 749; Weller, 1898, p. 427; Bassler and Moodey, 1943, p. 610; Moore and Laudon, 1944, p. 193, pl. 77, fig. 8; LaUdon, 1948, pl. 3; BowsheR, 1954, p. 113, figs. 1-3; WeBSTER, 1973, p. 206; Brower, 1970, p. 504, pl. 65, figs. 5-14; fig. 82, nos. C-K; WeBster, 1977, p. 135; WeBSTER, 2003.

Diagnosis.—Calyx conical with straight or slightly rounded sides, strongly necked base; basals with small notches at sutures; tegmen almost flat to gently convex, distinctly lobate; anal opening elevated slightly bulging, opens anteriorly.

Material examined.-M-6 (x2), M-13 (x2), M-15 (x76), M-16 (x1), M-17 (x105), M-18 (x1), M-19 (x22), M-22 (x17), M-86 (x1), M-87 (x10), M-89 (x2), M-91 (x5), M-92 (x5), M-93 (x3), M-94 (x12), M-95 (x29), M-98 (x1), M-100 (x3), M-151 (x7), M-154 (x1), M-158 (x4), M-159 
(x1), FC5 (x1), FC15 (x2), Indiana University 10565 (x16), an unknown locality (x2), USNM 6409 (x1), USNM (x4), Laudon 13,999 (x1), and Laudon 13,803 (x1).

Discussion.-Physetocrinus lobatus differs from other members of the genus by having distinct lobes on the tegmen. Other species, such as P. ornatus (Hall, 1858) and P. asper (Meek and Worthen, 1870), have grooves at the arm openings, but these grooves do not extend across the whole of the tegmen. The lobes of $P$. lobatus are more deeply grooved and can be followed to the anal opening. The best taxonomic reference for $P$. lobatus is Wachsmuth and Springer (1897).

Occurrence.-Indian Wells Canyon, Marble Canyon, Tierra Blanca Mountain, Black Range undefined, Rock Springs, Apache Hill, between North Percha Creek and Mineral Creek, Percha Creek Fork, Percha Creek, North Percha Creek, 0 Bar 0 Canyon, North Hollow Creek, and Wittenberg Ranch Windmill Section; and Thunder Springs Member or Mooney Falls Member of Redwall Limestone, Arizona.

Superfamiy CARPOCRINACEA de Koninck and Le Hon, 1854

Family Batocrinidae Wachsmuth and Springer, 1881

Genus Aвatocrinus Lane, 1963

Type species.-Actinocrinus turbinatus Hall, 1858; by original designation.

Diagnosis. - Calyx high, sides straight or gently concave; basal and radial circlets high and prominent; interrays not in contact with tegmen; tegmen as high or lower than calyx; anal tube stout and central. 


\section{Abatocrinus AEQUALIS (Hall, 1858)}

Figure 1.13.7-1.13.8

Actinocrinus aequalis Hall, 1858, p. 592, pl. 11, figs. 4a-4b; fig. 90; ShUmard, 1868, p. 341;

Miller, S. A., 1889, p. 217; Weller, 1898, p. 123.

Actinocrinus (Batocrinus) aequalis (Hall, 1858). Roemer, C. F., 1876, pl. 40, fig. 5; Frech, 1902, pl. 40, fig. 5; Bassler and Moodey, 1943, p. 321.

Batocrinus aequalis (Hall, 1858). Miller, S. A., 1889, p. 227; Miller, S. A., 1897, p. 735;

Wachsmuth And Springer, 1897, p. 371, pl. 28, figs. 5-6; Weller, 1898, p. 123; Schmidt, H., 1929, p. 83, pl. 20, fig. 13; Bassler and Moodey, 1943, p. 321; Laudon, 1973, p. 27, fig. 3;

WEBSTER, 1977, p. 47.

Abatocrinus aequalis (Hall, 1858). LAne, N. G., 1963, p. 696; WeBster, 1973, p. 30; WeBster, 2003; Ausich and Kammer, 2010, p. 40.

Batocrinus aequabilis Miller and Gurley, 1893, p. 25, pl. 5, figs. 13-15 (sic); Bassler And Moodey, 1943, p. 332.

Actinocrinus discoideus Hall, 1858, p. 594, Pl. 2, fig. 9.

Actinocrinus discoidues (Hall, 1858) (sic). Shumard, 1868, p. 343.

Batocrinus discoideus (Hall, 1858). Miller, S. A., 1889, p. 227; Whitfield, 1893b, p. 14, pl. 1, figs. 19-20; Weller, 1898, p. 135; Bassler And Moodey, 1943, p. 332.

Actinocrinus formosus Hall, 1859, p. 30, unnumbered fig; Shumard, 1868, p. 344; Hall, 1872c, pl. 3-A, fig. 1; Miller, S. A., 1889, p. 218; Weller, 1898, p. 135; Bassler And Moodey, 1943, p. 332; Lane, N. G., 1963, p. 696; Webster, 1973, p. 30.

Batocrinus formosus (Hall, 1859). MilLER, S. A., 1889, p. 228. 
Actinocrinus subaequalis Mcchesney, 1861, p. 17; McChesney, 1865, pl. 5, figs. 7a-7b;

MCCHesney, 1868, p. 13, pl. 5, figs. 7a-7b; unnumbered fig. p. 14; ShumARD, 1868, p. $348 .$.

Batocrinus subaequalis (McChesney, 1861). Miller, S. A., 1889, p. 228; Wachsmuth AND

Springer, 1897, p. 369, pl. 4, fig. 10; pl. 28, figs. 7-9; Weller, 1898, p. 135; Grabau and

Shimer, 1910, p. 541; Bassler and Moodey, 1943, p. 332; Moore and Laudon, 1943, p. 140,

pl. 11, fig. 10; Moore and Laudon, 1944, p. 195, pl. 75, fig. 5; Laudon, 1948, pl. 2; Laudon,

1973b, p. 27, fig. 3; WeBster, 1973, p. 66; WeBster, 1977, p. 47.

Abatocrinus subaequalis (McChesney, 1861). Rose, 1967, p. 24, pl. 17, fig. 6; WeBster, 1977, p.

47; Wolf, 1983, p. 170, pl. 23, fig. 3.

Actinocrinus doris Hall, 1861b, p. 15; Shumard, 1868, p. 343; Miller, S. A., 1889, p. 218;

WelLer, 1898, p. 123; Bassler and Moodey, 1943, p. 321.

Batocrinus doris (Hall, 1861). MilLeR, S. A., 1889, p. 227.

Diagnosis.-Calyx same height as tegmen; both calyx and tegmen are medium cone-shaped.

Material examined.-Laudon 13,822 (x1) and Laudon 14,261 (x1).

Discussion.-Abatocrinus aequalis and A. clypeatus are associated with the deeper water sediments of the Nunn Member. This suggests this genus preferred the quieter waters associated with the Waulsortian mounds instead of the slightly more turbulent waters of the shallow shelf. The best taxonomic reference for A. aequalis is Wachsmuth and Springer (1897).

Occurrence.—Marble Canyon; Chouteau Limestone, Missouri; and lower Burlington Limestone, Iowa.

Abatocrinus clypeatus (Hall, 1859) 
Figure 1.15.1-1.15.2

Actinocrinus clypeatus Hald, 1859, p. 12, unnumbered figure; Shumard, 1868, p. 343; Hall, 1872b, pl. 3, fig. 12; WeBster, 1973, p. 31.

Batocrinus clypeatus (Hall, 1859). Miller, S. A., 1889, p. 227; WachSmuth And Springer, 1889, p. 342, pl. 18, fig. 5; W ACHSMUth AND Springer, 1897, p. 380, pl. 27, figs. 8a-8e; Weller, 1898, p. 125; Grabau and Shimer, 1910, p. 541; Bassler and Moodey, 1943, p. 323; Laudon, 1973b, p. 27, figs. 3-4; Haugh, 1975a, p. 484, pl. 5, fig. 5; Haugh, 1975b, p. 267, fig. 5, no. 1; fig. 6, no. 7; WEBSTER, 1977, p. 47.

Abatocrinus clypeatus (Hall, 1859). Lane, N. G., 1963, p. 697; WeBster, 1973, p. 31; Ubaghs in Moore and Teichert, 1978, p. T214, fig. 184, no. 3; Webster, 1986, p. 41; Webster, 2003; Ausich and Kammer, 2010, p. 40.

Actinocrinus inornatus Hald, 1859, p. 24; Shumard, 1868, p. 344.

Batocrinus inornatus (Hall, 1859). Miller, S. A., 1889, p. 228; WhitField, 1893, p. 15, pl. 2, figs. 1-3; Wachsmuth and Springer, 1897, p. 380, pl. 5, fig. 17; Weller, 1898, p. 125; Bassler and Moodey, 1943, p. 323.

Actinocrinus papillatus Hald, 1859, p. 29, unnumbered figure; Shumard, 1868, p. 346; Hall, 1872c, pl. 3-A, figs. 10-11; Miller, S. A., 1889, p. 219; Weller, 1898, p. 125; Bassler AND Moodey, 1943, p. 323.

Batocrinus papillatus (Hall, 1859). Miller, S. A., 1889, p. 228.

Batocrinus quasillus MeeK and Worthen, 1868a, p. 351; Meek and Worthen, 1873, p. 367, pl. 5, figs. 2a-2b; Miller, S. A., 1889, p. 228; Wachsmuth And Springer, 1897, p. 372, pl. 28, figs. 
4a-4b; Weller, 1898, p. 132; Bassler and Moodey, 1943, p. 329; Lane, 1963, p. 697;

WeBster, 1973, p. 31.

Batocrinus comparilis Miller, S. A., 1892a, p. 675; Miller, S. A., 1892b, p. 32, pl. 5, figs. 18-

20; Miller, S. A., 1894, p. 286, pl. 5, figs. 18-19; Weller, 1898, p. 125.

Batocrinus aspratilis Miller And Gurley, 1893, p. 21, pl. 5, figs. 4-6; Miller, S. A., 1897, p. 735;

Weller, 1898, p. 125; Bassler And Moodey, 1943, p. 323.

Diagnosis.-Calyx higher than tegmen; sides of calyx concave.

Material examined.-M-7 (1966) (x1) and Laudon 13,557 (x3).

Discussion.-Basals are not preserved in any of the specimens. The concave sides of the calyx make Abatocrinus clypeatus distinct from the similar species A. turbinatus (Hall, 1858), which has much straighter sides and less of an overhang at arm level. The best taxonomic reference for A. clypeatus is Wachsmuth and Springer (1897).

Occurrence.-Indian Wells Canyon and Marble Canyon; Chouteau Limestone, Missouri; and lower Burlington Limestone, Iowa.

Genus ERETMOCRINus Lyon and Casseday, 1859

Type species._Eretmocrinus magnificus Lyon and Casseday, 1859; by original designation.

Diagnosis.—Calyx low, broad; basals low, form projecting rim; interrays not in contact with tegmen; tegmen as high or higher than calyx, asymmetric and bulging, highest anteriorly, flattened posteriorly; anal tube short and curved in some species.

ERETMOCRINUS CORBULIS (Hall, 1861a) 
Figure 1.15.3-1.15.4

Actinocrinus corbulis Hall, 1861a, p. 265; Hall, 1861b, p. 1; Hall, 1861c, p. 265; ShUmard, 1868, p. 343.

Eretmocrinus corbulis (Hall, 1861). Miller, S. A., 1889, p. 243; KeYes, 1894a, p. 175, pl. 23.

Wachsmuth and Springer, 1897, p. 399, pl. 36, figs. 5-6; Miller, S. A., 1897, p. 744; Weller, 1898, p. 249; Bassler and Moodey, 1943, p. 456; Webster, 1977, p. 79; Webster, 2003;

Ausich and Kammer, 2010, p. 43.

Eretmocrinus corbulus (Hall, 1861). LAUdON, 1973, p. 28, fig. 4.

Batocrinus corbulis (Hall, 1861). Miller, S. A., 1897, p. 736.

Diagnosis.-Calyx medium globe, plates nodose; basals deeply notched at sutures; nodes on radials project downward.

Material examined.-Laudon 14,041 (x1).

Discussion.-The basal flange that is characteristic for the genus Eretmocrinus is not quite as distinct in E. corbulis as it is in other species. The basals do not project outward, but rather downward. The best taxonomic reference for E. corbulis is Wachsmuth and Springer (1897).

Occurrence.-Tierra Blanca Mountain; and lower Burlington Limestone, Iowa.

Genus Eutrochocrinus Wachsmuth and Springer, 1897

Type species.-Actinocrinus christyi Shumard, 1855; by original designation.

Diagnosis.-Calyx narrow proximally, abruptly expanding above radials; interrays may or may not be in contact with tegmen; tegmen flat peripherally, rising centrally to form anal tube. 


\section{EUTROCHOCRINUS CHRYSTYI (Shumard, 1855)}

Figure 1.15.5-1.15.6

Actinocrinus christyi Shumard, 1855, p. 191, pl. A, fig. 3; Shumard, 1868, p. 342; ?Bigsby, 1868, p. 196; Quenstedt, 1876a, p. 742, pl. 17, fig. 17; QuensteDt , 1876b, p. 581, pl. 11-A, figs. 15-18; MilLeR, S. A., 1889, p. 217.

Eutrochocrinus christyi (Shumard, 1855). WACHSMUTH AND SpRINGER, 1897, p. 409, pl. 3, fig. 21; pl. 4, figs. 7, 13, 16; pl. 5, fig. 10; pl. 29, fig. 6; pl. 32, figs. 1a-1c; Weller, 1898, p. 270; Grabau and Shimer, 1910, p. 542, fig. 1871; Bassler and Moodey, 1943, p. 477; Moore and Laudon, 1943, p. 141, pl. 12, fig. 11; Moore and Laudon, 1944, p. 197, pl. 75, fig. 8; pl. 76, fig. 21; Laudon, 1948, pl. 2. Ubaghs, 1953, p. 740, fig. 22, no. c; Good, 1968, pl. 1, fig. 4; Laudon, 1973, p. 28, fig. 4; Webster, 1973, p. 130; Haugh, 1975a, p. 479, pls. 1, fig. 2; pl. 3, figs. 1, 4; pl. 5, fig. 8; UвAGHs in Moore and Teichet, 1978, p. T118, T201, fig. 90, no. 4; fig. 170, no. 6; fig. 171; Lane in Moore and Teichert, 1978, p. T469, fig. 276, no. 1; Wolf, 1979, p. 151, fig. 2, no. g. Haugh and Bell, 1980, p. 654, fig. 2, no. A; Webster, 1986, p. 148;

Webster, 2003; Ausich and Kammer, 2010, p. 43.

Actinocrinus cristii (Shumard, 1855) (sic). Quenstedt, 1867, p. 742, pl. 71, fig. 17. Actinocrinites cristii (Shumard, 1855) (sic). Quenstedt, 1885, p. 956, pl. 77, fig. 4. Batocrinus christyi (Shumard, 1855). Meek and Worthen, 1873, p. 367, pl. 5, fig. 4; Miller, S.

A., 1889, p. 227; Weller, 1898, p. 270; Bassler and Moodey, 1943, p. 477.

Eutrochocrinus christi (Shumard, 1855). McLEAd, 1973, p. 244, pls. 1, fig. 3; 2, fig. 5.

Eutrochocrinus christyi var. trochiscus WACHSMUtH AND SpRINGER, 1897, p. 410, pl. 32, fig. 3;

BAssler and Moodey, 1943, p. 478. 
Eutrochocrinus christyi trochiscus Wachsmuth and Springer, 1897. Weller, 1898, p. 270;

Laudon, 1973, p. 28, figs. 1, 4; WeBster, 1977, p. 85.

Batocrinus altiusculus Miller and Gurley, 1893, p. 20, pl. 5, figs. 1-3; Miller, S. A., 1897, p.

735; Weller, 1898, p. 270; Bassler and Moodey, 1943, p. 477.

Batocrinus bisbrachiatus Whitfield, 1893, p. 13, pl. 2, figs. 4-5; MilLeR, S. A., 1897, p. 735;

Weller, 1898, p. 270; Bassler and Moodey, 1943, p. 478.

Actinocrinites sp. Christy, 1848, pl. 1, figs. 1-2; Weller, 1898, p. 270.

Diagnosis.—Arm openings continuous; interrays not in contact with tegmen.

Material examined.-M-6 (x1) and Laudon 13,806 (x1).

Discussion.— Wachsmuth and Springer (1897) stated that both Eutrochocrinus christyi and E. lovei (Wachsmuth and Springer, 1881) closely resemble each other and are difficult to separate unless arms are preserved or the arm openings are perfectly preserved. Neither of these qualifiers are the case for the Nunn specimens, but it appears the presence of a depression between rays may be a clue. The illustrations of Wachsmuth and Springer (1897, E. christyi: pl. 29, fig. 6 and pl. 32, figs. 1a-1c, 3; E. lovei: pl. 29, fig. 7 and pl. 32, figs. 2a-b) also indicate this slight difference between the two species. The best taxonomic reference for Eutrochocrinus christyi is Wachsmuth and Springer (1897).

Occurrence.-Indian Wells Canyon and Tierra Blanca Mountain; Chouteau Limestone, Missouri; Fern Glen Limestone and upper Burlington Limestone, Iowa; and St. Joe Formation, Arkansas.

EutrochoCRINUS Lover (Wachsmuth and Springer, 1881) 
Figure 1.15.7-1.15.8

Batocrinus lovei Wachsmuth And Springer, 1881, p. 168 (342).

Batocrinus lovii Wachsmuth and Springer, 1881 (sic). Miller, S. A., 1889, p. 228.

Eutrochocrinus lovei (Wachsmuth and Springer, 1881). WACHSMUTH AND SPRINGER, 1897, p. 412,

pl. 29, fig. 7; pl. 32, figs. 2a-2b; Weller, 1898, p. 270; Bassler And Moodey, 1943, p. 478;

Webster, 2003; Ausich and Kammer, 2010, p. 43.

Diagnosis.-Arms grouped, separated by slight depression between rays; interrays in contact with tegmen.

Material examined.-Laudon, 13,569 (x1).

Discussion.-The occurrence of Eutrochocrinus lovei in the Nunn Member extends the range of the species to be older than once thought. The best taxonomic reference for E. lovei is Wachsmuth and Springer, (1897).

Occurrence.-Marble Canyon; and upper Burlington Limestone, Iowa.

Genus Simatocrinus Ausich and Kammer, 2010

Type species._-Batocrinus heteroclitus Miller and Gurley, 1895; by original designation.

Diagnosis. - Calyx low cone or expanding with concave sides; basals low, truncate or narrow proximal expansion; radials low; interrays in contact with tegmen; rays lobate; tegmen as high or higher than calyx, flat to low cone- or inverted bowl-shaped; anal tube central and cylindrical.

SiMATOCRINUS SP.

Figure 1.15.9-1.15.10 
Diagnosis._Basals low, expand outward; arm facets face obliquely upward; arms weakly grouped.

Material examined.-M-17 (x1) and M-91 (x1).

Discussion.-Two specimens of Simatocrinus occur in the collections. Neither is well preserved. Individual plates of the calyx are not easy to discern, therefore assigning these two specimens to a species is difficult.

Occurrence.—Black Range and between North Percha Creek and Mineral Creek.

Genus UPEROOCRINUs Meek and Worthen, 1865

Type species.-Actinocrinus pyriformis Shumard, 1855; by original designation.

Diagnosis. - Calyx expanding with concave sides or low to medium cone; basal and radial circlets high and prominent; interrays in contact with tegmen; rays may be lobate; tegmen as high or lower than calyx, flat to low cone or low inverted bowl; anal tube central and cylindrical.

\section{UPEROOCRINUS KUESI $\mathrm{n}$. sp.}

Figure 1.16.1-1.16.2, Table 1.6

Diagnosis.-Calyx plates nodose; tegmen lower than calyx.

Description.-Calyx expanding with concave sides. Arms moderately grouped. Calyx plates either nodose or smooth. Basal circlet is 16 percent of calyx height and composed of three large, equal plates that are trilobate. Radial circlet is $30 \%$ of the calyx height. Radials are hexagonal or heptagonal, wider than long, with a prominent node in the center. Tegmen low arched, slightly lobed between rays. Composed of many large, convex plates. Anal tube 
eccentric. Primanal hexagonal; higher and narrow than radials. Primanal followed by 3,2,1 plates. Interrays in contact with tegmen. First interradial hexagonal, large, and followed by 2 plates. First primibrachial hexagonal, wider than high. Second primibrachial axillary. Both have centural node. First secundibrachial hexagonal, second axillary, both with central node. Each axillary secundibrachial supports two tertibrachials.

$$
\text { Material examined.—UMMP } 70471 \text { (holotype) }
$$

Discussion.-Uperocrinus kuesi appears to be a mixture of two previously known species of Uperocrinus (Table 1.7). In overall shape, U. kuesi resembles $U$. hageri (McChesney, 1861), however, the basals are much more pronounced in $U$. kuesi, and the calyx plates are nodose. Uperocrinus marinus (Miller and Gurley 1890) has the same calyx nodes as U. kuesi, but the anal tube is stouter. Though the full anal tube is not preserved on $U$. kuesi, the base of the tube is small and narrow, much like $U$. hageri.

Occurrence.-Berenda Canyon.

Etymology.-The trivial name recognizes Dr. Barry Kues, who was kind enough to share his expertise at the different Lake Valley Formation collecting sites.

\section{UPEROOCRINUS SP.}

Figure 1.16.3-1.16.4

Diagnosis.—Calyx plates smooth; tegmen slightly lobed, low inverted bowl; many large, smooth plates on tegmen; anal tube eccentric.

Material examined.—Laudon 13,553 (x1). 
Discussion.—Basals and radials are not preserved, but this specimen appears to be most similar to Uperocrinus pyriformis (Shumard, 1855), which is what Laudon concluded.

Occurrence.-Marble Canyon.

\author{
Family Coelocrinidae Bather, 1899
}

Genus Agaricocrinus Hall, 1858

Type species.—Agaricocrinus tuberosus Hall, 1858; by subsequent designation (Miller and Gurley, 1897).

Diagnosis.-Calyx conical or hemispherical; basals flat or concave, basals and commonly radials not visible in side view; interrays in contact with tegmen; tegmen higher than calyx, conical or hemispherical; tegmen plates commonly large, tumid, or nodose; CD oral commonly large; anal opening on side of tegmen.

\title{
Agaricocrinus bullatus Hall, 1858
}

Figure 1.16.5-1.16.6

Agaricocrinus bullatus Hall, 1858, p. 662, pl. 9, figs. 11a-11b; Shumard, 1868, p. 351; MilleR, S. A., 1889, p. 220; Wachsmuth And Springer, 1897, p. 489, pl. 41, figs. 2a-2d; Weller, 1898, p. 68; Grabau and Shimer, 1910, p. 534; Bassler and Moodey, 1943, p. 285; Ehlers and Kesling, 1963, p. 1030; Mclead, 1973, p. 244, pl. 1, fig. 6; Webster, 1973, p. 41; Webster, 1977, p. 32; WeBster, 2003. 
Agaricocrinites bullatus (Hall, 1858). Moore AND Laudon, 1942, p. 74, fig. 4, no. c; Moore AND Laudon, 1943, p. 141, pl. 12, fig. 4; Moore and Laudon, 1944, p. 195, pl. 76, fig. 14;

Webster, 1973, p. 41.

Agaricocrinus pentagonus Hall, 1859, p. 57, unnumbered figure; Shumard, 1868, p. 351;

Miller, S. A., 1889, p. 221; Whitfield, 1893, p. 25, pl. 2, figs. 17-18; Keyes, 1894, p. 167, pl.

22, fig. 9; Miller, S. A., 1897, p. 732; Weller, 1898, p. 68; Bassler and Moodey, 1943, p.

285.

Diagnosis.—Calyx depressed pyramidal, pentangular below arm bases, deeply concave at bottom; tegmen high, hemispherical, much higher than calyx.

Material examined.-M-80(1971) (x1).

Discussion.-Agaricocrinus bullatus separates itself from the other species of Agaricocrinus in the Nunn Member by having a tegmen that is more boxy and much higher than the calyx. The best taxonomic reference for A. bullatus is Wachsmuth and Springer (1897).

Occurrence.-Indian Wells Canyon; lower and upper Burlington Limestone, Iowa; and Warsaw Limestone, Illinois.

Agaricocrinus planoconvexus Hall, 1861a

Figure 1.17.1-1.17.2

Agaricocrinus (Amphoracrinus) planoconvexus Hall, 1861a, p. 280; Hall, 1861c, p. 280. Agaricocrinus planoconvexus Hall, 1861b, p. 3; Shumard, 1868, p. 351; Miller, S. A., 1889, p. 221; Keyes, 1894, p. 167, pl. 22, figs. 7a-7b; Wachsmuth and Springer, 1897, p. 503, pl. 38, figs. 6a-6c; Weller, 1898, p. 71; Grabau and Shimer, 1910, p. 534; Bassler and Moodey, 
1943, p. 288; Ehlers and Kesling, 1963, p. 1030; Good, 1968, pl. 1, fig. 3; Laudon, 1973, p.

30, figs. 1-2; Webster, 1973, p. 42; Webster, 1977, p. 33; Webster, 2003. Agaricocrinites planoconvexus (Hall, 1861). Moore And Laudon, 1943, p. 141, pl. 12, fig. 3;

Moore and Laudon, 1944, p. 195, pl. 76, fig. 13; Laudon, 1948, pl. 2. Agaricocrinus decornis Rowley and Hare, 1891, p. 117, pl. 3, fig. 10; Weller, 1898, p. 71;

Bassler and Moodey, 1943, p. 28.

Diagnosis.—Calyx distinctly pentangular, bottom wholly or partly excavated; tegmen low, hemispherical, higher than calyx.

Material examined.-M-13, M-15 (x39), M-16 (x3), M-17 (x41), M-19 (x2), M-22 (x10), M80(1971) (x1), M-87 (x8), M-91 (x9), M-92 (x2), M-94 (x5), M-95 (x6), M-101 (x1), M-102 (x2), M-151 (x2), M-158 (x5), Kues1 (x4), Kues2 (x2), Indiana University 10565 (x5), an unknown locality (x1), USNM 6408 (x3), Laudon 13,997 (x1), Laudon 13,863 (x3), Laudon 13,986 (x4), and Laudon 13,552 (x1).

Discussion.-Agaricocrinus planoconvexus is the most abundant species of the genus in the Nunn Member and one of the most abundant species of camerates. The characteristic size range of the species is a calyx width between $9 \mathrm{~mm}-15 \mathrm{~mm}$, but a few grew much larger, having a calyx width of $25 \mathrm{~mm}$. The best taxonomic reference for A. planoconvexus is Wachsmuth and Springer (1897).

Occurrence.-Indian Wells Canyon, Marble Canyon, Tierra Blanca Mountain, Black Range undefined, Rock Springs, Apache hill, between North Percha Creek and Mineral Creek, Percha Creek, North Hollow Creek, Wittenberg Ranch Windmill Section, and Cooks Range; Chouteau 
Limestone, Missouri; lower and upper Burlington Limestone, Iowa; and Nada Member of the Borden Formation in Kentucky.

\section{Agaricocrinus PYRAmidatus (Hall, 1858)}

Figure 1.17.3-1.17.4

Actinocrinus pyramidatus Hall, 1858, p. 565; Shumard, 1868, p. 347.

Agaricocrinus pyramidatus (Hall, 1858). Miller, S. A., 1889, p. 221; Whitfield, 1893, p. 23, pl.

2, figs. 23-25; WachSmuth and Springer, 1897, p. 512, pl. 38, figs. 4-5; Weller, 1898, p. 72;

Grabau and Shimer, 1910, p. 534; Bassler and Moodey, 1943, p. 288; Ehlers and Kesling,

1963, p. 1031; WeBster, 1973, p. 42; WeBster, 2003.

Agaricocrinus (Amphoracrinus) corrugatus Hald, 1861a, p. 283; Hall, 1861c, p. 283; WelleR, 1898, p. 72; Bassler And Moodey, 1943, p. 288.

Agaricocrinus corrugatus Hall, 1861b, p. 4; Shumard, 1868, p. 351; Miller, S. A., 1889, p. 220;

Wachsmuth and Springer, 1897, p. 512; Weller, 1898, p. 72; Bassler and Moodey, 1943, p. 288.

Diagnosis.-Calyx flat; tegmen low, depressed pyramidal, higher than calyx.

Material examined.-Indiana University 10565 (x1).

Discussion.-The calyx of Agaricocrinus pyramidatus is unlike the previous two species of Agaricocrinus. Where A. bullatus and A. planoconvexus have flat calyces where the arm facets rest evenly on a horizontal plane, $A$. pyramidatus is slightly elevated by the radials so that the arm facets are not even with the horizontal. The best taxonomic reference for A. pyramidatus is Wachsmuth and Springer (1897). 
Occurrence.—Apache Hill; and lower Burlington Limestone, Iowa.

\section{Agaricocrinus ALAMOGORDOENSIS n. sp.}

Figure 1.17.5-1.17.6, Table 1.8

Diagnosis.—Calyx low cone; tegmen high cone, same height as calyx.

Description.-Calyx small, low cone, convex. Basals small, three, equal, form a concavity, edges visible in side view. Radials medium, hexagonal, wider than high with prominent node in center. Tegmen higher than calyx. Composed of several medium convex to nodose plates. CD oral largest pate, spinose. Primanal hexagonal, higher and narrower than radials, followed by three rows of three plates before the anal opening, which is on the side of the tegmen. First primibrachial hexagonal, wider than high. Second primibrachial axillary, supporting secundibrachials, which support one arm facet apiece. Arms and column unknown.

Material examined.-UMMP 74072 (holotype).

Discussion.-This species is similar to Agaricocrinus brevis (Hall, 1858), but the anal area is significantly different (Table 1.9). The primanal of A. brevis is followed by 3, 4(5), then numerous smaller plates, whereas in this species the primanal is followed by $3,3,3$. This species also lacks the well-defined groove at the sides of the anal area that $A$. brevis has.

The A and D rays of the holotype have slight variation from the other three rays, which are presumably the normal condition for Agaricocrinus alamogordoensis. The A ray only has one primibrachial, which is axillary as opposed to two as in the other rays. The D ray has three arm facets rather than two. The secundibrachial on the anal side is axillary, supporting two 
tertibrachials, which in turn supports the arm facets. Opposite the anal side, there are two secundibrachials before the arm facet.

Occurrence.-Indian Wells Canyon.

Etymology.-The trivial name recognizes the city of Alamogordo, NM near where the holotype specimen was collected.

\section{Coelocrinidae indet.}

Discussion. - Three crinoids are poorly preserved and cannot be identified any further than family level. Two of the specimens were identified by Laudon as being Dorycrinus unicornis (Owen and Shumard, 1850) but neither specimens are whole and it impossible to be certain of this identification. The third specimen only has the anal area, illustrating the distinct anal plates, but this is insufficient for identification.

Material examined.—M-159 (x1), Laudon 14,088 (x1), and Laudon 13,551 (x1).

Occurrence.-Marble Canyon and Percha Creek.

Superfamily HeXACRINITACEA Wachsmuth and Springer, 1885

Family DichocRINIDAe Miller, 1889

Genus Dichocrinus Münster, 1839

Type species.—Dichocrinus radiatus Münster, 1839; by original designation.

Diagnosis.—Calyx high bowl-shaped, small; basals and radials high; tegmen lower than calyx, composed of numerous small plates; anal opening eccentric. 
DichocRinus Conus Meek and Worthen, 1860

Figure 1.17.7-1.17.9

Dichocrinus conus Meek and Worthen, 1860, p. 381; Meek and Worthen, 1866a, p. 169, pl. 16, figs. 5a-5b; Shumard, 1868, p. 366; Miller, S. A., 1889, p. 239; Wachsmuth and Springer, 1897, p. 770, pl. 75, fig. 6; Weller, 1898, p. 221; Bassler ANd Moodey, 1943, p. 419;

Broadhead, 1981, p. 107, pl. 7, figs. 1-3, 6, 12-13, 16; WeBster, 1988, p. 71; Webster, 2003.

Dichocrinus scitulus Hall, 1861a, p. 289; Hall, 1861b, p. 4; Hall, 1861c, p. 289; Shumard, 1868, p. 366; Hall, 1872c, pl. 2-A, figs. 12-13; Miller, S. A., 1889, p. 239; WachSmuth AND Springer, 1897, p. 767, pl. 78, figs. 13a- 14; Weller, 1898, p. 224; Bassler and Moodey, 1943, p. 422; Laudon, 1973, p. 32, fig. 7; Webster, 1977, p. 70; Webster, 2003.

Platycrinus elegans Hall, 1861a, p. 285; Hall, 1861b, p. 4; Hall, 1861c, p. 285; SHumard, 1868, p. 388; Hall, 1872a, pl. 2A, fig. 15; Miller, S. A., 1889, p. 270; Whitfield, 1893, p. 3, fig. 1; Miller, S. A., 1897, p. 750; Weller, 1898, p. 438; Bassler and Moodey, 1943, p. 619; WeBster, 2003.

Platycrinites elegans (Hall, 1861). BAssLer AND Moodey, 1943, p. 619.

Diagnosis.—Calyx inornate, plates smooth; basal cup conical.

Material examined.-M-17 (x1), M-102 (x1), Indiana University 10565 (x1), Laudon 14,272 (x1), and Laudon 13,765 (x1).

Discussion.-Two species of Dichocrinus (D. conus and D. scitulus) as well as Platycrinites elegans were synonymized by Broadhead (1981), but this was not recognized by Webster (2003). The best taxonomic references for $D$. conus are Wachsmuth and Springer (1897) and Broadhead (1981). 
Occurrence.—Black Range undefined, Apache Hill, Wittenberg Ranch Windmill Section, and Cooks Range; lower and upper Burlington Limestone, Iowa; and Boone Formation, Arkansas.

\author{
DiCHOCRINUS SP.
}

Figure 1.17.10-1.17.11

Material examined.-M-7(1966) (x1).

Discussion.-This specimen is poorly preserved, with only the radials and anal plate. It is likely that it is Dichocrinus conus, but without a full calyx, it is not possible to confidently assign it to a species.

Occurrence.-Indian Wells Canyon.

Genus Strimplecrinus Broadhead, 1981

Type species.—Dichocrinus plicatus Hall, 1861; by original designation.

Diagnosis.—Calyx low to medium bowl, rarely conical; basals and radials high; tegmen lower than calyx, composed of many small plates.

Discussion.-Strimplecrinus is very similar to Dichocrinus with the calyx shape an important difference between the two genera. Strimplecrinus is more globose than Dichocrinus. Another difference may be that Strimplecrinus has an anal tube. However, the only known tegmen for Strimplecrinus is from the oldest known species. That feature may have been lost in later species, therefore it cannot be used as a distinguishing character until more tegmens are found. 
STRIMPLECRINUS PISUM (Meek and Worthen, 1869)

Figure 1.18.1-1.18.2

Dichocrinus pisum Meek and Worthen, 1869, p. 69; Meek and Worthen, 1873, p. 441, pl. 3, fig. 2; Miller, S. A., 1889, p. 239; Wachsmuth And Springer, 1897, p. 763, pl. 76, fig. 5; pl. 77, fig. 10; Weller, 1898, p. 224; Bassler and Moodey, 1943, p. 422; Laudon, 1973, p. 32, fig. 7. Strimplecrinus pisum (Meek and Worthen, 1869). BROADHEAD, 1981, p. 141, pl. 14, fig. 10; pl. 15, figs. 1-2, 6, 10, 22; Broadhead, 1985, p. 211, fig. 5, no. A; Webster, 1988, p. 153; Webster, 2003.

Dichocrinus prisus (Meek and Worthen, 1869) (sic). WeBster, 1977, p. 70.

Diagnosis.-Calyx short; basals broadly expanding, shallow; radial circlet vertical to slightly contracted to summit; plates plicate to striate.

Material examined.-M-15 (x2).

Discussion.-Neither specimen is perfectly preserved, but both has striations. The basals are broad and shallow, which separates them from Strimplecrinus striatus (Owen \& Shumard, 1850). The basals also lack nodose striae, which separates it from S. ovatus (Owen \& Shumard, 1850). One specimen preserves the striae very well. The other has been abraded but the ghosts of the striae can still be discerned on the plates. The best taxonomic references for S. pisum are Wachsmuth and Springer (1897) and Broadhead (1981).

Occurrence.-Black Range undefined; and lower Burlington Limestone, Iowa. 
Figure 1.18.3

Material examined.-M-9 (x1).

Discussion.-The specimen of this dichocrinid is crushed, but the width of the radial plates is indicative of Strimplecrinus. Placing this specimen in a species is difficult, as there appears to be no ornamentation. The only known Strimplecrinus species that are inornate are either from the Kinderhookian (S. campto (Laudon, 1933) and S. inornatus (Wachsmuth \& Springer, 1890)) or the Chesterian (S. superstes (Wachsmuth \& Springer, 1897)). Although it is conceivable that this species is a holdover from the Kinderhookian, with only one example, any definitive species assignment is impossible.

Occurrence.-Indian Wells Canyon.

Suborder GLyPTOCRINIA Moore, 1952

Superfamily Platycrinitacea Austin and Austin, 1842

Family Platycrinitidae Austin and Austin, 1842

Genus Platycrinites Miller, 1821

Type species._Platycrinites laevis Miller, 1821; by subsequent designation (Meek \& Worthen, 1865).

Diagnosis.—Calyx low to medium bowl; basal circlet high, visible in side view; radials lack laterally projecting neck at radial facet; five or ten arm openings; tegmen medium to low cone, as high or lower than calyx; few to numerous small- to medium-sized tegmen plates; tegmen plate size gradational from orals to margins; anal tube on top or upper margin of tegmen. 
Platycrinites S.S. BuRlingtonensis (Owen and Shumard, 1850)

Figure 1.18.4-1.18.5

Platycrinus burlingtonensis Owen and Shumard, 1850, p. 60, pl. 7, fig. 5; Owen AND Shumard, 1852, p. 589, pl. 5A, fig. 5; Shumard, 1868, p. 387; MCCHeSney, 1868, p. 4, pl. 4, fig. 3;

Wachsmuth and Springer, 1885, pl. 8, fig. 6; pl. 9, fig. 6; Lesley, 1889, p. 686, fig. 1;

WachSmuth and Springer, 1897, p. 653, pl. 69, figs. 3a-3l; Weller, 1898, p. 435; Grabau AND

Shimer, 1910, p. 518, fig. 1839; Breimer, 1962, p. 139, fig. 32; Webster, 1973, p. 211.

Platycrinites burlingtonensis (Owen and Shumard, 1850). MeeK and Worthen, 1873, p. 452, pl.

3, figs. 6a-6c; Bassler and Moodey, 1943, p. 617; Moore and Laudon, 1944, p. 203, pl. 78,

fig. 24; Webster, 1973, p. 211; Webster, 2003.

Platycrinites s.s. burlingtonensis (Owen and Shumard, 1850). Ausich And Kammer, 2009, p. 702.

Platycrinus exsertus Hall, 1858, p. 549, unnumbered figure; Shumard, 1868, p. 388; Miller, S.

A., 1889, p. 270; Bassler AND Moodey, 1943, p. 617.

Platycrinus exertus (Hall, 1858) (sic). WeLLER, 1898, p. 435.

Platycrinus nodobrachiatus Hall, 1858, p. 542, unnumbered figure; Hall, 1861b, p. 17.

Shumard, 1868, p. 388; Miller, S. A., 1889, p. 271; Weller, 1898, p. 435; Bassler AND

Moodey, 1943, p. 617.

Platycrinus nucleiformis Hall, 1858, p. 540, unnumbered figure; Shumard, 1868, p. 388; Miller,

S. A., 1889, p. 271; WelleR, 1898, p. 435; Bassler and Moodey, 1943, p. 617.

Platycrinus inornatus Mcchesney, 1861, p. 7; Shumard, 1868, p. 387; Miller, S. A., 1889, p.

271; Miller, S. A., 1897, p. 750; Weller, 1898, p. 436; Bassler and Moodey, 1943, p. 617. 
Platycrinus lautus Miller, S. A., 1891a, p. 17, pl. 2, figs. 3-4; Miller, S. A., 1892a, p. 681;

Weller, 1898, p. 436; Bassler and Moodey, 1943, p. 617.

Diagnosis.—Calyx smooth; plate sutures not pronounced; arm facets large; tegmen low, few medium to large plates.

Material examined.—M-7 (x1), an unknown locality (x1), and Laudon 13,757 (x1).

Discussion.—Platycrinites burlingtonensis can be readily separated from the similar Nunn Member species $P$. illinoisensis by having plate sutures that are not well pronounced. The latter species has deep groves where the calyx plates connect, whereas $P$. burlingtonensis is very smooth. The best taxonomic reference for $P$. burlingtonensis is Wachsmuth and Springer (1897).

Occurrence.-Indian Wells Canyon; and lower Burlington Limestone, Iowa.

Platycrinites S.S. ILLinoisensis (Miller and Gurley, 1896a)

Figure 1.18.8-1.18.9

Platycrinus illinoisensis Miller and Gurley, 1896a, p. 62, pl. 5, figs. 5-7; Miller, S. A., 1897, p. 750; WeLLeR, 1898, p. 441.

Platycrinites illinoisensis (Miller and Gurley, 1896). Bassler and Moodey, 1943, p. 622;

WeBster, 2003.

Platycrinites s.l. illinoisensis (Miller and Gurley, 1896); Ausich And Kammer, 2009, p. 704.

Diagnosis.—Calyx smooth; plate sutures deeply beveled; arm facets large; tegmen low, few large plates. 
Description.—Calyx flat bowl, plates smooth. Basal circlet flat, slight depression where column meets calyx. Radial circlet 80 percent of calyx height, plates smooth. Radial facets approximately 75 percent of distal radial width. Tegmen lower than calyx, low inverted bowl, composed of few large, nodose plates; orals largest with other tegmen plates slightly smaller. Primanal large. Column and arms are unknown.

Material examined.-M-86 (x1), M-176 (x1), Laudon 13,775 (x1), and Laudon 13, 787 (x1).

Discussion.-Ausich and Kammer (2009) assigned Platycrinites illinoisensis to Platycrinites sensu lato because of a lack of information on the tegmen. Miller and Gurley (1896a) described the holotype without any information on the tegmen. The specimens collected in the Nunn Member match the illustrations of the Burlington Limestone calyces perfectly and it is with confidence that these specimens are being placed into this species. With the addition of the tegmen which has an anal tube, this species can be removed from Platycrinites sensu lato and placed in Platycrinites sensu stricto following the convention of Ausich and Kammer (2009).

Occurrence.-Indian Wells Canyon, and Apache Hill; and Burlington Limestone, Iowa, Illinois.

\section{Platycrinites S.S. PARVINOdus (Hall, 1861b)}

Figure 1.18.6-1.18.7

Platycrinus parvinodus Hall, 1861b, p. 17; Shumard, 1868, p. 389; Miller, S. A., 1889, p. 271;

Wachsmuth And Springer, 1897, p. 696, pl. 68, figs. 6a-6b; Weller, 1898, p. 442.

Platycrinites parvinodus (Hall, 1861). BAssler And Moodey, 1943, p. 624; WeBster, 2003.

Platycrinites s.l. parvinodus (Hall, 1861). Ausich AND KAMmer, 2009, p. 704. 
Diagnosis. - Calyx plates contain nodes that radiate from arm facet to either corner of radial; sutures indistinct; arm facets small; tegmen low to medium bowl, with few to numerous small to medium plates.

Description.-Calyx medium bowl, plates nodose. Basal circlet low with small nodes that cover the plates. Radial circlet approximately 70 percent of calyx height, covered in fine nodes that may form lines that radiate from the radial facet. Radial facet approximately 45 percent of the distal radial width. Tegmen lower than calyx; low to medium bowl with few to numerous smooth plates. Primanal large. Arms and column not known.

Material examined.-M-15 (x7), M-17 (x6), M-19 (x2), M-92 (x1), M-95 (x2), an unknown locality (x1), Laudon 13,727 (x1), Laudon 13,833 (x1), and Laudon 13,768 (x2).

Discussion.-Ausich and Kammer (2009) placed this species in Platycrinites sensu lato because only the calyx has been known for this species. The specimens collected in the Nunn Member match the only illustration of the calyx in Wachsmuth and Springer (1897, pl. 68, fig. 6a-6b), so it with confidence that this species is assigned to these specimens. With the addition of the tegmen and evidence of an anal tube, this species may be removed from Platycrinites s.l. and placed in Platycrinities s.s.

The specimens of Platycrinites parvinodus have a wide range of variation, although the overall characteristics remain the same. Some specimens have more nodes that cover all of the basals and radials instead of only distinct lines. The height of the tegmen varies as well; from being nearly flat to being one half the height of the calyx.

Occurrence.-Black Range undefined, North Hollow Creek, Tierra Blanca Mountain, and Wittenberg Ranch Windmill Section; and lower Burlington Limestone, Iowa. 
Platycrinites S.s. PeCUliaris (Wachsmuth and Springer, 1897)

Figure 1.18.10-1.18.11

Platycrinus peculiaris Wachsmuth And Springer, 1897, p. 700, pl. 68, figs. 7a-7b; pl. 71, fig. 16;

Miller, S. A., 1897, p. 750; Weller, 1898, p. 443; Bassler and Moodey, 1943, p. 624.

Platycrinites peculiaris (Wachsmuth and Springer, 1897). BAssler And Moodey, 1943, p. 624;

Haugh, 1978, p. 166, figs. 15, no. D; 17, no. G; Webster, 1986, p. 255; Webster, 2003.

Platycrinites s.s. peculiaris (Wachsmuth and Springer, 1897). Ausich And Kammer, 2009, p. 702.

Diagnosis.—Calyx smooth; plate sutures not pronounced; arm facets small; tegmen $3 / 4$ height of calyx, with numerous small plates.

Material examined.-M-7 (x3), M-15 (x2), M-22 (x1), M-80(1971) (x1), M-86 (x3), M-95

(x1), FC16 (x1), Indiana University 10565 (x8), an unknown locality (x5), Laudon 13,765 (x1), Laudon 13,833 (x2), Laudon 13,825 (x1), Laudon 13,777 (x7), Laudon 13,794 (x1), Laudon 13,781 (x2), Laudon 13,755 (x1), Laudon 13,750 (x1), Laudon 13,838 (x2), Laudon 13,836 (x1), and Laudon 13,766 (x1).

Discussion.-This is the dominant species of Platycrinites in the Nunn Member based on the collections studied. The number of specimens includes a wide range of size differences from small $(10.4 \times 8.4 \mathrm{~mm})$ to large $(24.4 \times 18.6 \mathrm{~mm})$. In his collection, Laudon assigned at least three separate new species names (unpublished) to the different $P$. peculiaris, but the only difference between them is the size. The best taxonomic reference for $P$. peculiaris is Wachsmuth and Springer (1897). 
Occurrence.-Indian Wells Canyon, Black Range undefined, Rock Springs, Apache Hill, North Hollow Creek, and Wittenberg Ranch Windmill Section.

\section{PLATYCRINITES SP.}

Figure 1.19.1-1.19.2

Diagnosis.-Calyx elongate, smooth; plate sutures not pronounced; arm facets large; tegmen low; plates smooth; orals nodose

Material examined.-M-15 (x1), and an unknown locality (x2).

Discussion.-Three specimens of Platycrinites look unlike any other found in the Nunn Member. It is believed that these three, of varying sizes, represent different ages for one species. The tegmen is the same for all three. The two smaller specimens have a calyx that is not quite as elongate as the larger one. More specimens need to be found before a trivial name can be placed on them.

Occurrence.-Black Range undefined.

Genus Collicrinus Ausich and Kammer, 2009

Type species.—Collicrinus shumardi Ausich and Kammer, 2009; by original designation.

Diagnosis. - Calyx flat to very low cone; basal circlet low, not visible in side view; radials lack laterally projecting neck at radial facet; five arm openings; tegmen low inverted bowl, lower, as high, or higher than calyx; few large-sized tegmen plates; tegmen plates not gradational from orals to margins; anal tube from upper margin or side of tegmen. 
COLLICRINUS SHUMARDI Ausich and Kammer, 2009

Figure 1.19.3-1.19.4

Collicrinus shumardi Ausich And Kammer, 2009, p. 712, figs. 3.4-3.6.

Platycrinus yandelli Owen And Shumard, 1850, p. 58, pl. 7, figs. 6a-6b; Owen AND Shumard, 1852,

p. 547, pl. 5a, figs. 6a-6b; Shumard, 1868, p. 390; Wachsmuth AND SpRinger, 1889, p. 342, pl.

18, fig. 8; Miller, S. A., 1889, p. 272; Lesley, 1889, p. 690, figs. 6a-6b; Wachsmuth And

Springer, 1897 (in part), p. 706, pl. 66, figs. 6a; pl. 68, figs. 3a-3c; Weller, 1898, p. 448;

BReIMER, 1962, p. 139, fig. 32.

Platycrinites yandelli (Owen and Shumard, 1850). Bassler and Moodey, 1943, p. 629. Webster,

1973, p. 215; WEBSTER, 2003.

Diagnosis.—Calyx plates nodose to short spinose; tegmen higher than calyx; anal tube on margin, projects upward.

Material examined.-M-15 (x2) and Indiana University 10565 (x1).

Discussion.-The Nunn Member specimens of Collicrinus shumardi are not well preserved. However, the preservation is well enough to confidently assign to this species. The calyx plates do not have coarse sculpturing, and the anal tube projects upward and not laterally, as with the other known member of this genus, C. formosus (Miller and Gurley, 1895b). The best taxonomic reference for Collicrinus shumardi is Ausich and Kammer (2009).

Occurrence.—Black Range undefined and Apache Hill; and lower Burlington Limestone, Iowa. 


\section{Collicrinus laudoni $\mathrm{n}$. $\mathrm{sp}$.}

Figure 1.19.5-1.19.6, Table 1.10

Diagnosis.-Calyx plates smooth; tegmen lower than calyx; anal tube on margin, projects obliquely upward.

Description.-Aboral cup flat bowl, plates smooth. Basal circlet flat, visible in lateral view. Radial circlet 85 percent of calyx height. Radial plates five, as wide as high and smooth. Radial facet 80 percent width of distal radial width. Tegmen lower than calyx; low inverted bowl, composed of large nodose plates. Orals largest plates and other tegmen plates slightly smaller. Primanal large. Plates surrounding primanal indistinguishable, but anal tube starts immediately above primanal. Primibrachial large, axillary. Other aspects of arms and column unknown.

Material examined.-UMMP 74073 (holotype).

Discussion.-This species is similar to Collicrinus formosus (Miller and Gurley, 1895a), but differs in that the basals are not within a concavity, the calyx lacks plate ornamentation, and the anal tube opens along the margin of the tegmen, not on the side (Table 1.11). Collicrinus laudoni differs from $C$. shumardi by having basals that are visible in lateral view and smooth calyx plates.

Occurrence.-Apache Hill.

Etymology.- The trivial name recognizes Dr. Lowell Laudon, who did some of the first extensive studies on the Lake Valley Formation and who collected a portion of the crinoids used in this study. 
Genus Elegantocrinus Ausich and Kammer, 2009

Type species._Platycrinus hemisphaericus Meek and Worthen, 1865; by original designation.

Diagnosis.-Calyx low bowl to cone; basal circlet high, visible from side view; radials lack laterally projecting neck at radial facet; five or ten arm openings; tegmen medium to low inverted bowl, lower than calyx; numerous medium- to small-sized plates; plate size gradational from orals to margin; anal tube absent, anus on side of tegmen.

\section{Elegantocrinus ANNOSUs (Miller, 1891a) n. comb.}

Figure 1.19.9-1.19.10

Platycrinus annosus Miller, S. A., 1891a, p. 14, pl. 1, fig. 12; Miller, S. A., 1897, p. 750, fig. 1373; Weller, 1898, p. 434; Peck and Keyte, 1938, p. 90, pl. 30, figs. 6-8; Bassler and Moodey, 1943, p. 615.

Platycrinus anosus (Miller, 1891) (sic). Miller, S. A., 1892a, p. 681. Platycrinites annosus (Miller, 1891). Bassler And Moodey, 1943, p. 615; Webster, 2003. Platycrinites s.l. annosus (Miller, 1891). Ausich And Kammer, 2009, p. 704.

Diagnosis.-Calyx smooth, bowl-shaped; plate sutures not well pronounced; arm facets small.

Description.-Calyx low bowl, plates smooth. Basal circlet low, plates smooth, column facet small. Radial circlet approximately 70 percent of calyx height. Radial facets small, approximately 50 percent of distal radial width. Tegmen flat inverted bowl, many small nodose plates. Anal open on side of tegmen. Arms and column not known. 


\section{Material examined.-M-18 (x1).}

Discussion.-Ausich and Kammer (2009) placed this species in Platycrinites sensu lato due to a lack of information on the tegmen. The specimen from the Nunn is identical to the illustrations of the calyx and as the specimen lacks evidence of an anal tube on the wellpreserved tegmen, it is placed in the genus Elegantocrinus.

Occurrence.—Black Range undefined; and Chouteau Limestone, Missouri.

$$
\text { Elegantocrinus Canaliculatus (Hall, 1858) n. comb. }
$$

Figure 1.19.7-1.19.8

Platycrinus canaliculatus Hall, 1858, p. 539; Shumard, 1868, p. 387; Miller, S. A., 1889, p.

270; Wachsmuth and Springer, 1897, p. 689, pl. 75, figs. 7a-7b; Weller, 1898, p. 436.

Platycrinites canaliculatus (Hall, 1858). Bassler and Moodey, 1943, p. 617; Webster, 2003.

Platycrinites s.l. canaliculatus (Hall, 1858). Ausich AND Kammer, 2009, p. 704.

Diagnosis.—Calyx bowl shaped, plates contain large nodes; basals low; plate sutures well defined; arm facets large.

Description.—Calyx low bowl, plates with few nodes. Basal circlet flat, plates have a few nodes on them; slight depression where column attaches. Radial circlet approximately 85 percent of calyx height, plates with few nodes forming lines that radiate from radial facets. Radial facets approximately 50 percent of distal radial width. Tegmen low inverted bowl with large orals and smaller plates surrounding. Tegmen plates nodose. Anal opening is on side of the tegmen. Arms and column not known.

Material examined.—M-7 (x1), Laudon 13,824 (x1), and Laudon unknown no. (x1). 
Discussion.-Ausich and Kammer (2009) placed the species in Platycrinites sensu lato due to a lack of information on the tegmen. The specimens from Nunn are identical to the illustrations of the calyx and as the specimen lacks evidence of an anal tube on the wellpreserved tegmen, it is placed in the genus Elegantocrinus.

Occurrence.-Indian Wells Canyon and Tierra Blanca Mountain; and lower and upper Burlington Limestone, Iowa.

\section{Elegantocrinus Nodostriatus (Wachsmuth and Springer, 1897)}

Figure 1.20.1-1.20.2

Platycrinus nodo-striatus WaChSMUTH AND SpRInGeR, 1897, p. 698, pl. 66, figs. 5a-5b; pl. 70, figs. 3-4c.

Platycrinus nodostriatus (Wachsmuth and Springer, 1897). Miller, S. A., 1897, p. 750; BAssLeR AND Moodey, 1943, p. 623; WelleR, 1898, p. 442.

Platycrinites nodostriatus (Wachsmuth and Springer, 1897). BAssLer AND Moodey, 1943, p. 623;

Brower, 1970, p. 524, pl. 66, fig. 8; fig. 86, no. C; Laudon, 1973, p. 31, fig. 6; Webster, 1977, p. 138; WeBSTER, 2003.

Elegantocrinus nodostriatus (Wachsmuth and Springer, 1897). Ausich And Kammer, 2009, p.709.

Diagnosis.-Calyx bowl-shaped, plates contain very fine nodes; plate sutures not well pronounced; arm facets small.

Material examined.—Indiana University 10565 (x1). 
Discussion.-Elegantocrinus nodostriatus is similar to E. canaliculatus in shape of the theca but differs in having much smaller nodes on the radials and having smaller arm facets. The best taxonomic reference for E. nodostriatus is Wachsmuth and Springer (1897).

Occurrence.—Apache Hill; upper Burlington Limestone, Iowa; and Thunder Springs Member or Mooney Falls Member of Redwall Limestone, Arizona.

\section{Elegantocrinus PILEIFORMis (Hall, 1858) n. comb.}

Figure 1.20.5-1.20.6

Platycrinus pileiformis Hall, 1858, 529, pl. 8, figs. 3a-3c; fig. 5b; Shumard, 1868, p. 389;

Miller, S. A., 1889, p. 271; Keyes, 1894, p. 198, pl. 25, fig. 5; Wachsmuth And Springer, 1897, p. 656, pl. 69, fig. 5; pl. 70, figs. 13a-13b; Weller, 1898, p. 443; Steinmann, 1903, p.

175, fig. 230, nos. C-D; fig. 242, nos. C-D; Steinmann, 1907, p. 195, fig. 277, no. C. Platycrinites pileiformis (Hall, 1858). Bassler and Moodey, 1943, p. 624; Laudon, 1973b, p. 31,

fig. 6; WeBster, 1977, p. 138; Webster, 2003.

Platycrinites s.l. pileiformis (Hall, 1858). Ausich And Kammer, 2009, p. 704.

Platycrinus carchesium Miller, S. A., 1891a, p. 23, figs. 6-7; Miller, S. A., 1892a, p. 681;

Weller, 1898, p. 443; Bassler and Moodey, 1943, p. 624.

Diagnosis.—Calyx cone-shaped, plates smooth; plate sutures not well pronounced; arm facets large.

Description.-Calyx high bowl, plates smooth. Basals high, smooth plates. Radial circlet approximately 66 percent of the calyx height. Radial facets approximately 60 percent of the 
distal radial width. Tegmen low inverted bowl with many medium, nodose plates. Anal opening on the side of the tegmen. Arms and column unknown.

Material examined.-M-15 (x1), M-17 (x2), M-86 (x1), Indiana University 10565 (x1), and Laudon 14,249 (x1).

Discussion.- Ausich and Kammer (2009) placed this species in Platycrinites sensu lato due to a lack of information on the tegmen. The specimens collected from the Nunn lack any evidence of an anal tube on the well-preserved tegmens and are therefore assigned to the genus Elegantocrinus. The upper Burlington species Elegantocrinus halli (Shumard, 1865) is similar to E. pileiformis, but the differences between the two species are in the length and number of arms, which the Nunn specimens are lacking. Because E. pileiformis is from the lower Burlington, it is the right age. Therefore, these specimens are placed in that species.

Occurrence.-Marble Canyon, Black Range undefined, and Apache Hill; Chouteau Limestone, Missouri; and lower Burlington Limestone, Iowa.

ELEGANTOCRINUS POCILLIFORMIS (Hall, 1858) n. comb.

Figure 1.20.3-1.20.4

Platycrinus pocilliformis Hall, 1858, p. 528, pl. 8, figs. 2a-2b; WaCHSMUTH AND SPRINGER, 1897, p. 706, pl. 68, figs. 2a-2b; Shumard, 1868, p. 389; Miller, S. A., 1889, p. 271; Weller, 1898, p. 444; Moore, 1939 p. 199, fig. 8, nos. 1a-1b.

Platycrinites pocilliformis (Hall, 1858). Bassler And MoOdey, 1943, p. 625; Webster, 2003.

Platycrinites s.l. pocilliformis (Hall, 1858). Ausich and Kammer, 2009. 
Diagnosis.—Calyx bowl-shaped, plates contain small nodes; plates sutures moderately developed; arm facets small.

Description.-Calyx low bowl, plates smooth to slightly nodose. Basals low, flat. Radial circlet approximately 75 percent of the calyx height. Radial facets approximately 70 percent of the distal radial width. Tegmen low inverted bowl, with many small plates that are smooth and convex. Anal opening on side of tegmen. Arms and column unknown.

Material examined.-M-7 (x1), M-15 (x1), M-17 (x2), M-80 (x2), M-94 (x1), Laudon 13,778 (x2), Laudon 13,754 (x1), Laudon 13,779 (x1), Laudon 13,980 (x1), Laudon 13,769 (x4), and Laudon 13,855 (x1).

Discussion.- Ausich and Kammer (2009) placed this species in Platycrinites sensu lato due to a lack of information on the tegmen. The specimens from the Nunn are identical to the illustrations of the calyx and as the specimen lacks evidence of an anal tube on the wellpreserved tegmen, it is placed in the genus Elegantocrinus.

Elegantocrinus pocilliformis is similar to E. nodostriatus, but the latter has much finer nodes that almost coalesce to form lines around the edges of the plates. The former's nodes, though relatively small, are not nearly as numerous and do not form a linear pattern.

Occurrence.- Indian Wells Canyon, Black Range undefined, North Hollow Creek, Hillsboro, and Tierra Blanca Mountain; and lower Burlington Limestone, Iowa.

\section{ELEGANTOCRINUS SP. A}

Figure 1.20.7-1.20.8 
Diagnosis.—Calyx plates smooth; basals low; plate sutures moderately developed; arm facets small.

Material Examined.-M-17 (x1), M-87 (x1), and Laudon 14,030 (x1).

Discussion.-These three specimens appear to most closely resemble Platycrinites peculiaris with the noticeable exception that they lack an anal tube. They also have affinity to the Western European species Elegantocrinus externus (Wright, 1956). There is a possibility that these specimens are younger forms of E. pileiformis. The specimens are in varying states of

preservation. One is crushed, one lacks a tegmen (though the anal opening is preserved), and the third, though whole, is degraded in such a way it is difficult to make out features. Because of this, no name will be placed on these specimens until better ones can be acquired.

Occurrence.-Black Range undefined, Apache Hill, and Wittenberg Ranch Windmill Section.

\section{ELEGANTOCRINUS SP. B}

Figure 1.20.9-1.20.10

Diagnosis.—Calyx plates nodose; basals low; plate sutures well developed; arm facets small to medium; tegmen $3 / 4$ the height of calyx.

Material Examined.-M-94 (x2).

Discussion.-Two specimens of Elegantocrinus have a higher tegmen than the others in the Nunn Member. The tegmen is about $3 / 4$ the height of the calyx and inflated compared to the other species of Elegantocrinus. The calyx most closely resembles that of E. pocilliformis in ornamentation and shape. 
Occurrence.--North Hollow Creek.

Genus Eucladocrinus Meek, 1872

Type species._Platycrinites (Eucladocrinus) montanaensis Meek, 1872; by original designation.

Diagnosis. - Calyx low to medium bowl; basal circlet high (rarely low), visible in side view; radials lack laterally projecting neck at radial facet; five arm openings; arm trunks present; tegmen flat to medium inverted bowl, lower than calyx; many medium-sized tegmen plates; tegmen plate size not gradational from orals to margins; anal tube absent, anus on side of tegmen.

Discussion.-The occurrence of Eucladocrinus in the Nunn Member fills in the time gap of the genus being from the latest Kinderhookian (Time Unit 2) and the upper Burlington (Time Unit 4) (Ausich and Kammer, 2006, Table 1).

\section{Eucladocrinus PLeURovimenus (White, 1862)}

Figure 1.20.11

Platycrinus pleurovimenus White, C. A., 1862, p. 17; Shumard, 1868, p. 389; Miller, S. A., 1889, p. 271.

Eucladocrinus pleurovimenus (White, 1862). Weller, 1898, p. 261; Moore and Laudon, 1944, p. 205, pl. 78, fig. 28; Laudon, 1973, p. 31, fig. 6; WeBster, 2003.

Platycrinus pleuroviminus (White, 1862) (sic). BAssLer And Moodey, 1943, p. 470. 
Eucladocrinus pleuroviminus (White, 1862) (sic). Miller, S. A., 1889, p. 244; Wachsmuth AND

Springer, 1897, p. 724, pl. 73, fig. 4; pl. 74, fig. 1; BASSLER AND Moodey, 1943, p. 470;

Ubaghs, 1953, p. 743, fig. 102; Webster, 1973, p. 127; Lane in Moore and Teichert, 1978, p.

T515, fig. 317, no. 3;Webster, 1986, p. 145; Ausich and Kammer, 2009, p. 706.

Eucladocrinus pleurovimineus (White, 1862) (sic). Moore and Laudon, 1943, p. 143, pl. 14, fig.

13; WeBSTER, 1977, p. 83.

Platycrinus discoideus Hald, 1858, p. 535, pl. 8, figs. 8a-8b (non Owen and Shumard, 1850);

Weller, 1898, p. 261; Bassler and Moodey, 1943, p. 470.

Diagnosis.—Basal circlet low, flat, barely visible in side view; radial plates moderately spreading.

Material examined.-M-7 (x1), M-17 (x2), M-80 (x2), M-86 (x1), Indiana University 10565 (x2), and an unknown locality (x1).

Discussion.-The occurrence of Eucladocrinus pleurovimenus in the Nunn Member extends the range of the species, making it slightly older than known previously.

In trying to determine the species, Eucladocrinus praenuntius (Wachsmuth and Springer, 1878) was also considered as it supposedly closely resembles E. pleurovimenus. However, the single illustration of the species is only of the oral surface (Wachsmuth and Springer, 1897, Pl. 73, fig. 5). The original description is not accompanied by an illustration, although Webster (2003) noted that a plate does accompany a separate of the paper in the Springer Collection at the U. S. National Museum and that it is unknown whether that separate was widely published or not. It is possible that E. praenuntius is a junior synonym of E. pleurovimenus based on 
description alone. The best taxonomic reference for E. pleurovimenus is Wachsmuth and Springer (1897).

Occurrence.-Indian Wells Canyon, Black Range undefined and Apache Hill; and upper Burlington Limestone, Iowa.

\section{EUCLADOCRINUS SP.}

Figure 1.20 .12

Diagnosis.—Basal circlet low, swollen, visible in side view; radial plates very spreading. Material examined.-Indiana University 10565 (x1) and Laudon 13,929 (x1).

Discussion.-Two specimens of Eucladocrinus are similar to E. pleurovimenus with a low basal circlet and spreading radials, but significant differences indicate it is a separate species. The basals on E. pleurovimenus are flat, making them relatively difficult to see in side view. Although low, the basals on Eucladocrinus sp. are swollen, making them visible in side view. The radials are also wider than those on E. pleurovimenus. These differences make it different from E. pleurovimenus, but other characters are needed to describe a new species.

Occurrence.—Apache Hill and Wittenberg Ranch Windmill Section.

\section{Genus Oenochoacrinus Breimer, 1962}

Type species.-Oenochoacrinus princeps Breimer, 1962; by original designation.

Diagnosis.—Calyx low to medium bowl, or expanding with concave sides; basal circlet high, visible in side view; radials lack laterally projecting neck at radial facet; ten arm openings; tegmen flat to low cone, lower than calyx; fifteen to few tegmen plates, ten small- or five 
medium-sized plates and five large-sized plates; tegmen plate size not gradational from orals to margins; anal tube absent, anus on side of tegmen.

Discussion.-The tegmen of the Mississippian species of Oenochoacrinus have more plates than the Devonian species. The tegmen of O. limbus and $O$. cortina both resemble the tegmen of O. pileatus (Breimer, 1962, fig. 30) except the medium-sized plates on the margin are now two small-sized plates. As this is the only difference, it is not necessary to erect a new genus.

\section{Oenochoacrinus Limbus Webster and Lane, 1987}

Figure 1.21.1-1.21.2

Oenochoacrinus limbus Webster and Lane, 1987, p. 41, fig. 11, nos. 12-23; Webster, 1993, p. 80; Webster, 2003; Ausich and Kammer, 2009, p. 707.

Diagnosis.—Calyx medium bowl; basal circlet high with flange; radial facets small.

Material examined.—M-80(1971) (x4), M-86 (x1), M-176, (x1) Indiana University 10565 (x7), an unknown locality (x3), Laudon 13,770 (x1), Laudon 13,759 (x1), Laudon 13,779 (x1), and Laudon 13,760 (x1).

Discussion.-Though the description of the genus lists at most ten plates in the tegmen, none of the Oenochoacrinus from the Nunn Member has that few. Most of the specimens have fifteen plates: five large orals in the center of the tegmen surrounded by ten medium sized plates over the arm facets. This is the same pattern in the O. limbus illustrations in Webster and Lane (1987). A couple of specimens have 20 plates in the tegmen. The pattern is the same as the 15- 
plated specimens, only with the addition of five small plates between the large orals and the medium plates.

Occurrence.-_Indian Wells Canyon and Apache Hill; and Anchor Limestone, Nevada.

OenochoAcrinus CORTINA (Miller and Gurley, 1894) n. comb.

Figure 1.21.3-1.21.4

Platycrinus cortina Miller and Gurley, 1894, p. 40, pl. 3, figs. 15-16; Miller, S. A., 1897, p.

750; Weller, 1898, p. 437; Peck and Keyte, 1938, p. 97, pl. 30, figs. 9-10.

Platycrinites cortina (Miller and Gurley, 1894). Bassler And Moodey, 1943, p. 618; Webster, 2003.

Platycrinites s.l. cortina (Miller and Gurley, 1894). Ausich And Kammer, 2009, p. 704

Diagnosis. - Calyx expanding cone with concave sides; basals high, no flange; radial facets one-half size as radial.

Description.-Calyx expanding cone with smooth plates. Basals high, slightly constricted at distal end. Radial circlet approximately 55 percent of calyx height. Radial facet approximately 70 percent of distal radial width. Tegmen low inverted bowl with five large orals and ten smaller plates that are over the arm facets as with most of the Oenochoacrinus limbus specimens. Anal opening on the side of the tegmen. Arms and column not known.

Material examined._-Laudon 13,834 (x1).

Discussion.-Ausich and Kammer (2009) placed Platycrinites cortina in Platycrinites s.l. because of poor specimen preservation with only an incomplete tegmen. They noted that it most likely belongs to either Oenochoacrinus or Pleurocrinus but tegmen characteristics must be 
known before it can be assigned to either. The single specimen in the Lake Valley collection has a calyx that greatly resembles the diagram of Peck and Keyte (1938, Pl. 30, fig. 9-10) with a tegmen that matches the 15-plated Oenochoacrinus limbus specimens also in the Nunn Member.

There is some confusion on the age of Oenochoacrinus cortina as it is reported in the literature as being from the Chouteau Limestone at Sedalia, Missouri, although it is most likely from the Burlington Limestone. Gahn and Kammer (2002, p. 127) address the issue of crinoids collected from Sedalia and their likely age.

Occurrence.-Indian Wells Canyon; and Chouteau Limestone, Missouri.

\section{Genus Plemnocrinus Kirk, 1946}

Type species._Plemnocrinus beebei Kirk, 1946; by original designation.

Diagnosis. - Calyx low to flat cone or bowl; basal circlet low, usually not visible in side view; radials have laterally projecting neck at radial facet; five arm openings; tegmen flat cone to inverted bowl, lower than calyx; many medium- to large-sized tegmen plates; tegmen plate size gradational from orals to abaxial margins; anal tube absent, anus on upper margin of tegmen.

\section{Plemnocrinus bullatus Kirk, 1946}

Figure 1.21.5-1.21.6

Plemnocrinus bullatus KIRK, 1946, p. 437, pl. 65, fig. 1; WeBSTER, 1973, p. 218; WeBster, 2003;

Ausich And Kammer, 2009, p. 707.

Diagnosis.—Calyx bowl shaped; basals protuberant, visible in lateral view; tegmen lower than calyx, plates nodose. 
Material examined.-M-7 (x2), M-13 (x2), M-15 (x40), M-16 (x1), M-17 (x49), M-19 (x3), M-22 (x2), M-87 (x2), M-93 (x1), M-94 (x4), M-95 (x23), M-102 (x1), M-158 (x1), Indiana University 10565 (x7), an unknown locality (x6), and Laudon 14,029 (x3).

Discussion.-Kirk (1946) described the tegmen of Plemnocrinus bullatus as high and domed, but this disagrees with the specimens in the Springer Collection that Kirk mentions in his paper. The tegmens of $P$. bullatus are not high, but low, and do not exceed the height of the calyx.

Occurrence.-Indian Wells Canyon, Tierra Blanca Mountain, Black Range undefined, Apache Hill, Rocks Springs, North Hollow Creek, Percha Creek, Wittenberg Ranch Windmill Section, and Cooks Range; and Burlington Limestone, Iowa.

\section{Plemnocrinus homalus Kirk, 1946}

Figure 1.21.7-1.21.8

Plemnocrinus homalus KIRK, 1946, p. 439, pl. 66, figs. 1-6; WeBster, 1973, p. 218; WeBster, 2003; Ausich And Kammer, 2009, p. 707

Diagnosis.—Calyx flat; basals not visible in lateral view; tegmen slightly higher than calyx, plates spinose.

Material examined.-M-6 (x1), M-7 (x9), M-9 (x3), M-13 (x4), M-15 (x112), M-16 (x4), M17 (x95), M-18(x1), M-19 (x4), M-22 (x26), M-69 (x1), M-73 (x8), M-80(1971) (x6), M-91 (x6), M-92 (x3), M-94 (x5), M-95 (x26), M-100 (x1), M-151 (x2), M-158 (x8), M-176 (x6), Barry1 (x1), Indiana University 10565 (x14), an unknown locality (x12), USNM 6462 (x4), Laudon 13,923 (x7), Laudon 14,072 (x1), and Laudon 14,029 (x2). 
Discussion.-The two species of Plemnocrinus that make up the majority of specimens in the genus in the Nunn Member (P. bullatus and $P$. homalus) may be two morphotypes of the same species. The tegmens are identical. The difference between the two species is the shape of the calyx, with $P$. homalus having a flat calyx and $P$. bullatus having a bowl shaped calyx. It could be a question of variation within one species. However, until further investigation can be done, the two will remain in separate species.

Occurrence.-Indian Wells Canyon, San Andres Canyon, Tierra Blanca Mountain, Black Range undefined, Rock Springs, Apache Hill, between North Percha Creek and Mineral Creek, Percha Creek Fork, Percha Creek, North Hollow Creek, and Wittenberg Ranch Windmill Section; and Burlington Limestone, Iowa.

Plemnocrinus subspinosus (Hall, 1858)

Figure 1.21.9-1.21.10

Platycrinus subspinosus Hall, 1858, p. 536, pl. 8, figs. 9-10; Shumard, 1868, p. 390; Miller, S. A., 1889, p. 272; Wachsmuth ANd Springer, 1897, p. 717, pl. 66, figs. 9a-9b; Weller, 1898, p. 446; Bather in Lankester, 1900, p. 158, fig. 71, no. 1; Delage and Herouard, 1904, p. 382, fig. 462; Grabau and Shimer, 1910, p. 519, fig. 1841; Springer in Zittel, 1913, p. 199, fig. 300; Wilson, H. E., 1916, p. 509, pl. 2, fig. 6.

Platycrinites subspinosus (Hall, 1858). Meek And Worthen, 1873, p. 452, pl. 11, fig. 2; Weller, 1898, p. 447; BAssLer AND Moodey, 1943, p. 627.

Platycrinus (Pleurocrinus) subspinosus Meek and Worthen, 1866a, p. 173, pl. 15, fig. 6; Bassler AND Moodey, 1943, p. 627. 
Plemnocrinus subspinosus (Hall, 1858). KIRK, 1946, p. 440; Webster, 1973, p. 218, Webster, 2003; Ausich and Kammer, 2009, p. 707.

Diagnosis.—Calyx flat; basals not visible in lateral view; tegmen domed, much higher than calyx, plates nodose or spinose; ambulacral plates differentiated.

Material examined.—M-17 (x2) and Indiana University 10565 (x2).

Discussion.-A distinct gradation exists in the few specimens of Plemnocrinus subspinosus in the collections studied. The smallest specimen looks exactly like the one figured in Wachsmuth and Springer (1897, pl. 66, fig. 9b), whereas the largest only vaguely resembles it. The tegmen on the largest specimen is nearly three times higher than the calyx on the smallest specimen with a tegmen only 1.5 times higher. The sides of the tegmen are also nearly vertical in the largest specimen, whereas the tegmen sides of the smallest specimen is more convex. However, the two medium-sized specimens are intermediary between the others. The largest specimen of Plemnocrinus subspinosus resembles Laticrinus oweni Ausich and Kammer (2009) as figured in Wachsmuth and Springer (1897, pl. 66, figs. 10b-10c), except that $P$. subspinosus has a radial plate with a projecting neck, whereas $L$. oweni does not. The best taxonomic references for P. subspinosus are Wachsmuth and Springer (1897) and Kirk (1946).

Occurrence.—Black Range undefined and Apache Hill; and lower Burlington Limestone, Iowa.

Genus Pleurocrinus Austin and Austin, 1843

Type species.-Pleurocrinus mucronatus Austin in Austin and Austin, 1843; by original designation. 
Diagnosis. - Calyx low bowl or expanding with concave sides; basal circlet high, visible in side view; radials without laterally projecting neck at radial facet; five arm openings; tegmen flat inverted bowl, lower than calyx; five distinct large orals surrounded by few to relatively numerous small tegmen plates, small- and large-sized tegmen plates; tegmen plate size not gradational from orals to abaxial margins; anal tube absent, anus on upper margin of tegmen.

\section{Pleurocrinus Quinquenodus (White, 1862)}

Figure 1.21.11-1.21.12

Platycrinus quinquenodus Whiтe, C. A., 1862 (adv. pub.); WhiтE, C. A., 1865, p. 18; Wachsmuth AND Springer, 1897, p. 661, pl. 71, figs. 14a-14c; Weller, 1898, p. 444; Bassler and Moodey, 1943, p. 625.

Platycrinus quenquenodus (White, 1862) (sic). Shumard, 1868, p. 389; Miller, S. A., 1889, p. 271.

Platycrinites quinquenodus (White, 1862). BAssler And Moodey, 1943, p. 625; Moore AND

Laudon, 1944, p. 203, pl. 78, fig. 19; Good, 1968, pl. 1, fig. 10; Laudon, 1973, p. 31, fig. 6;

Webster, 1973, p. 213; Webster, 1977, p. 139.

Pleurocrinus quinquenodus (White, 1892). Webster, 2003; Ausich And Kammer, 2009, p. 706.

Platycrinus plano-basalis Rowley and Hare, 1891, p. 97, pl. 2, fig. 1; Weller, 1898, p. 444.

Platycrinus planobasalis (Rowley And Hare, 1891). Miller, S. A., 1892a, p. 681; Bassler AND Moodey, 1943, p. 625.

Diagnosis.—Calyx low bowl; basals low. 
Material examined.-M-9 (x1), M-15 (x1), M-17 (x1), M-86 (x1), Laudon 13,611 (x1), Laudon 13,763 (x1), and Laudon 13,785 (x1).

Discussion.-The discovery of Pleurocrinus quiquenodus in the Nunn Member extends the range of this species downward from the upper Burlington Limestone The best taxonomic reference for $P$. quinquenodus is Wachsmuth and Springer (1897).

Occurrence.-Indian Wells Canyon, Marble Canyon, Black Range undefined, Tierra Blanca Mountain, and Apache Hill; and upper Burlington Limestone, Iowa.

\section{Pleurocrinus SP.}

Figure 1.21.13-1.21.14

Diagnosis.—Calyx medium bowl; basals high

Material examined.-M-15 (x1) and M-17 (x3).

Discussion.-Although they are similar to the Western European species of Pleurocrins tuberculatus (Miller, 1821), and P. bellmanensis (Wright, 1942) with a straight sided calyx, the Lake Valley specimens are so poorly preserved it is not possible to designate a new species. These specimens look nothing like either known North American species.

Occurrence.—Black Range undefined. 


\section{REFERENCES}

Anonymous. 1881. [Note on Lake Valley Fauna]. The American Naturalist, 15:671.

Ausich, W. I. And T. W. Kammer. 2006. Stratigraphical and geographical distribution of Mississippian (Lower Carboniferous) Crinoidea from England and Wales. Proceedings of the Yorkshire Geological Society, 56(1):91-109.

Ausich, W. I. And T. W. Kammer. 2008. Generic concepts in the Amphoracrinidae Bather, 1899 (Class Crinoidea) and evaluation of generic assignments of North American species. Journal of Paleontology, 82:1139-1149.

Ausich, W. I. and T. W. Kammer. 2009. Generic concepts in the Platycrinitidae Austin and Austin, 1842 (Class Crinoidea). Journal of Paleontology, 83:694-717.

Ausich, W. I. and T. W. Kammer. 2010. Generic concepts in the Batocrinidae Wachsmuth and Springer, 1881 (Class Crinoidea). Journal of Paleontology, 84:32-50.

Ausich, W. I. and G. D. Sevastopulo. 2001. The Lower Carboniferous (Tournaisian) crinoids from Hook Head, County Wexford, Ireland. Monograph of the Palaeontological Society 617, $136 \mathrm{p}$.

Austin, T. 1848. Observations on the Cystidea of M. Von Buch, and the Crinoidea generally. Geological Society of London, Quarterly Journal, 4:291-294.

Austin, T., SR. And T. Austin, JR. 1842. XVIII. - Proposed arrangement of the Echinodermata, particularly as regards the Crinoidea, and a subdivision of the Class Adelostella (Echinidae). Annals and Magazine of Natural History, series 1, 10:106-113.

Austin, T., SR. And T. Austin, Jr. 1843-1847. A monograph on recent and fossil Crinoidea, with figures and descriptions of some Recent and fossil allied genera. 1(2):1-32 (1843); 1(3):3348 (1844); 1(4):49-64 (1845); 1(5):65-80 (1846); 1(6-8):81-128 (1847). London and Bristol.

Bassler, R. S. 1938. Pelmatozoa Palaeozoica, p. 1-194. In W. Quenstedt (ed.), Fossilium Catalogus, I: Animalia. W. Junk, s'Gravenhage.

Bassler, R. S. And M. W. Moodey. 1943. Bibliographic and faunal index of Paleozoic pelmatozoan echinoderms. Geological Society of America Special Paper 45, 734 p.

Bather, F. A. 1899. A phylogenetic classification of the Pelmatozoa. British Association for the Advancement of Science (1898), 916-923. 
Bather, F. A. 1900. Part III The Echinoderma. The Pelmatozoa, p. 94-204, assisted by J. W. Gregory, and E. S. Goodrich. In E. R. Lankester (ed.), A Treatise on Zoology, Adam and Charles Black, London.

BigsBy, J. J. 1868. Thesaurus Siluricus; the flora and fauna of the Silurian period. With Addenda (from recent acquisitions). J. Van Hoorst, London, p. I-LII, 1-214.

BowsHeR, A. L. 1954. The stratigraphic significance of a crinoid from the Redwall Limestone of Arizona. Journal of Paleontology, 28:113-116.

BowsHeR, A. L. 1955. New genera of Mississippian camerate crinoids. Echinodermata Article 1, University of Kansas Paleontological Contributions, 23p.

Bowsher, A. L. 1978. Family Actinocrinitidae, T452-T462. In R. C. Moore and K. Teichert (eds.), Treatise on Invertebrate Paleontology, Echinodermata, Pt. T(2). Geological Society of America and University of Kansas Press, Boulder and Lawerence.

BReIMER, A. 1962. A monograph on Spanish Paleozoic crinoidea. Overdruk uit Leidse Geologische Mededelingen, Deel 27, 190 p.

BREZINSKI, D. K. 2000. Lower Mississippian trilobites from southern New Mexico. Journal of Paleontology, 74:1043-1064.

BROADHEAD, T. W. 1981. Carboniferous camerate crinoid subfamily, Dichocrininae. Palaeontographica, Abt. A, 176:81-157.

BroadheAd, T. W. 1985. Evolution of Carboniferous Hexacrinitacea (Criniodea, Camerata). Neuvième Congrès International de Stratigraphie et de Géologie du Carbonifère (1979), Compte Rendu, 5:205215.

BronN, H. G. 1849. Index palaeontologicus, unter Mitwirking der Herren Prof. H. R. Göppert und H. von Meyer. Handbuch einer Geschichte der Nature, 5, Abt. 1, A. Nomenclator Palaeontologicus, $1381 \mathrm{p}$.

BRower, J. C. 1965. The genus, Steganocrinus. Journal of Paleontology, 39:773-793.

BRower, J. C. 1967. The actinocrinitid genera Abactinocrinus, Aacocrinus and Blairocrinus. Journal of Paleontology, 41:675-705.

Brower, J. C. 1969. Chapter 12, Crinoids, p. 475-543. In E. D. McKee and R. C. Gutschick, History of the Redwall Limestone of northern Arizona. Geological Society of America Memoir 114 (1969). 
Brower, J. C. 1974. Ontogeny of camerate crinoids. University of Kansas Paleontological Contributions, Paper 72, 53 p.

Brower, J. C. 1978. Camerates, p. T244-T263. In R. C. Moore and K. Teichert (eds.), Treatise on Invertebrate Paleontology, Echinodermata, Pt. T(1). Geological Society of America and University of Kansas Press, Boulder and Lawerence.

BURKE, 1975

Christy, D. 1848. Letters on geology. J. M. Christy Printer, Rossville, Ohio, 98 p.

Cope, E. D. 1882. Invertebrate fossils from the Lake Valley district. The American Naturalist, 16:158-159

Delage, Y. and E. J. E. Herouard. 1904. Traité de zoologie concrète, Tome III: Les Echinodermes. Schleicher Frères, Paris, 495 p.

Ehlers, G. M. And R. V. Kesling. 1963. Two new crinoids from Lower Mississippian rocks in southeastern Kentucky. Journal of Paleontology, 37:1028-1041.

Frank, T. D., K. C. Lohmann, and W. J. Meyers. 1996. Chronostratigraphic significance of cathodoluminescence zoning in syntaxial cement; Mississippian Lake Valley Formation, New Mexico. Sedimentary Geology, 105:29-50.

FreCH, F. 1897-1902. Lethaea geognostica oder Beschreibung und Abbildung der für die GebirgsFormationen bezeichnendsten Versteinerungen. Herausgegeben von einer Vereinigung von Palaeontologen. (2 vols), I. Theil. Lethaea palaeozoica.

Gahn, F. J., And T. W. Kammer. 2002. The cladid crinoid Barycrinus from the Burlington Limestone (early Osagean) and the phylogenetics of the Mississippian botryocrinids. Journal of Paleontology, 76:123-133.

Good, D. L. 1968. The Burlington crinoids. Earth Science, 21:161-164.

Grabau, A. W. and H. W. Shimer. 1910. North American index fossils, invertebrates. Vol. 2. New York, 909 p.

HaLl, J. 1858. Chapter 8. Palaeontology of Iowa, p. 473-724. In J. Hall and J. D. Whitney, Report of the Geological Survey of the state of Iowa: Embracing the results of investigations made during portions of the years 1855, 56 \&: 57, v. 1, part II; Palaeontology, p. 473-724, 29 pl., index to Part II separately paginated, 3 p. 
HaLl, J. 1859. Contributions to the palaeontology of Iowa, being descriptions of new species of Crinoidea and other fossils. Supplement to vol. I, part II, of the Geological Report of Iowa, 92p.

Hall, J. 1861a. Descriptions of new species of Crinoidea from the Carboniferous rocks of the Mississippi Valley. Journal of the Boston Society of Natural History, 3:261-328.

Hall, J. 1861b. Descriptions of new species of crinoidea; from investigations of the Iowa Geological Survey, Preliminary notice. C. van Benthuysen, Albany, New York, 18 p.

Hall, J. 1861c. Descriptions of new species of Crinoidea from the Carboniferous rocks of the Mississippi valley. Journal of the Boston Society of Natural History, 7:261-328.

HaLl, J. 1863. Notice of some new species of fossil from a locality of the Niagara Group, in Indiana; with a list of identified species from the same place. $34 \mathrm{p}$.

Hall, J. 1872a. Description of new species of Crinoidea and other fossils from the strata of the age of the Hudson-River Group and Trenton Limestone. Twenty-fourth Annual Report of the New York State Museum of Natural History, by the Regents of the University of the State of New-York, Argus Company, Albany, State of New York in Senate Document No. 68, transmitted to the Legislature, April 18th, 1871, p. 205-224.

HaLl, J. 1872b, Description of new species of crinoidea from the Carboniferous rocks of the Mississippi Valley, p. 261-328.

Hammer, Ø., D. A. T. Harper, and P. D. Ryan. 2001. Paleontological Statistics (PAST) v. 2.03. $<$ http://folk.uio.no/ohammer/past/>.

Haugh, B. N. 1973. Water vascular system of the Crinoidea Camerata. Journal of Paleontology, 47:77-901.

Haugh, B. N. 1975a. Digestive and coelomic systems of Mississippian camerate crinoids. Journal of Paleontology, 49:472-493.

Haugh, B. N. 1975b. Nervous systems of Mississippian camerate crinoids. Paleobiology, 1:261272.

Haugh, B. N. 1978. Biodynamic and phyletic paradigms for sensury organs in camerate crinoids. Lethaia, 11:45-173.

Haugh, B. N. and B. M. Bell. 1980. Fossilized viscera in primitive echinoderms. Science, 209:653-657. 
Jeffery, D. L. and R. J. Stanton Jr. 1996. Growth history of Lower Mississippian Waulsortian mounds; distribution, stratal patterns, and geometries, New Mexico. Facies. 35:29-58.

JichA, H. L., Jr. 1954. Geology and mineral deposits of Lake Valley Quadrangle, Grant, Luna, and Sierra counties, New Mexico. Bulletin - New Mexico Bureau of Geology \& Mineral Resources, 93 p.

Keyes, C. R. 1890. Genesis of the Actinocrinidae. American Naturalist, 24(279):243-254.

Keyes, C. R. 1894. Paleontology of Missouri, Pt. I. Missouri Geological Survey, 4:143-225.

KIRK, E. 1911. The structure and relationships of certain eleutherozoic pelmatozoa. Proceedings of the U.S. National Museum, 41:1-137.

KIRK, E. 1943. A revision of the genus Steganocrinus. Journal of the Washington Academy of Science, 33:259-265.

KIRK, E. 1944. Cribanocrinus, a new rhodocrinoid genus. Journal of the Washington Academy of Science, 34:13-16.

KIRK, E. 1946. Plemnocrinus, a new crinoid genus from the Lower Misissippian. Journal of Paleontology, 20:435-441.

Koninck, L. G. De and H. Le Hon. 1854. Recherches sur les crinoides du terrain carbonifere de la Belgiqu. Academie Royal de Belgique, Memoir, 28(3), 215p.

Kruskat, J. B. 1964. Multidimensional scaling by optimizing goodness of fit to a nonmetric hypothesis. Psychometrics. 29:1-27.

Kues, B. S. 1986. Paleontology of the Caballero and Lake Valley formations (Lower Mississippian) west of the Rio Grande, south-central New Mexico; Truth or Consequences region. Guidebook - New Mexico Geological Society, 37:203-214.

Kues, B. S. 2008. Mississippian. In The Paleontology of New Mexico. University of New Mexico Press, Albuquerque, NM, United States, 96:113.

Lahusen, J. I. 1895. Kratkii kurs Paleontologhii Part I, St. Petersburg, p. 132-195.

Lane, H. R. 1974. Mississippian of Southeastern New Mexico and West Texas-A wedge-onwedge relation. The American Association of Petroleum Geologists Bulletin, 58:269-282.

Lane, H. R. 1982. The distribution of the Waulsortian facies in North America as exemplified in the Sacramento Mountains of New Mexico, p. 96-114. In K. Bolton, H. R. Lane, D. V. 
LeMone (eds.). Symposium on the paleoenvironmental setting and distribution of the Waulsortian facies.

Lane, H. R. 1984. Distribution of the Waulsortian facies (Early Mississippian) in North America; Limestones of the Mid-Continent. Tulsa Geological Society Special Publication, 2:259-271.

Lane, H. R. and P. L. Brenckle. 2001. Type Mississippian subdivisions and biostratigraphic succession, p. 83-107. In P.H. Heckle (ed.) Stratigraphy and Biostratigraphy of the Mississippian Subsystem (Carboniferous System) in its Type Region, the Mississippi River Valley of Illinois, Missouri, and Iowa. I.U.G.S. Subcommission on Carboniferous Stratigraphy Guidebook for Field Conference, St. Louis, MO.

Lane, N. G. 1963. Two new Mississippian camerate (Batocrinidae) crinoid genera. Journal of Paleontology, 37:691-702.

Lane, N. G. 1978a. Family Batocrinidae Wachsmuth and Springer, 1881, p. T466-T471. In R. C. Moore and K. Teichert (eds.), Treatise on Invertebrate Paleontology, Echinodermata, Pt. $\mathrm{T}(2)$. Geological Society of America and University of Kansas Press, Boulder and Lawerence.

Lane, N. G. 1978b. Family Platycrinitidae Austin \& Austin, 1842, p. T515-T519. In R. C. Moore and K. Teichert (eds.), Treatise on Invertebrate Paleontology, Echinodermata, Pt. T(2). Geological Society of America and University of Kansas Press, Boulder and Lawerence.

Lane, N. G. And J. R. Dubar. 1983. Progradation of the Borden delta: new evidence from crinoids. Journal of Paleontology, 57:112-123.

Lane, N. G., G. D. Sevastopulo, and H. L. Strimple. 1985. Amphipsalidocrinus; a monocyclic camerate microcrinoid. Journal of Paleontology, 59:79-84.

Laudon, L. R. 1933. The stratigraphy and paleontology of the Gilmore City Formation of Iowa. University of Iowa Studies, 15(2):1-74.

Laudon, L. R. 1948, Osage-Meramec contact. Journal of Geology, 56:288-302.

Laudon, L. R. 1973. Stratigraphic crinoid zonation in Iowa Mississippian rocks. Proceedings of the Iowa Academy of Science, 80:25-33.

Laudon, L. R. and A. L. Bowsher. 1949. Mississippian formations of southwestern New Mexico. Geological Society of America Bulletin, 60:1-37.

Lesley, J. P. 1889-1890. A dictionary of the fossils of Pennsylvania and neighboring states. Pennsylvania Geological Survey 2nd Report, P4, 1283p. 
Lyon, S. S. and S. A. Casseday. 1859. Description of nine new species of crinoidea from the Subcarboniferous rocks of Indiana and Kentucky. American Journal of Science and Arts, ser. 2, 28:233-246.

Macurda, D. B., JR. 1974. A quantitative phyletic study of the camerate crinoid Families Actinocrinitidae and Periechocrinitidae and its taxonomic implications. Journal of Paleontology, 48:820-832.

McChesney, J. H. 1861. Descriptions of new fossils from the Paleozoic rocks of the western states. Transactions of the Chicago Academy of Science, 2:77-95.

McChesney, J. H. 1865. Plates illustrating in part the new species of fossils from the Palaeozoic rocks of the western states. And two new species noticed March 1860.

McChesney, J. H. 1868. Descriptions of fossils from the Palaeozoic rocks of the western states. Transactions of the Chicago Academy of Science, 1:1-57.

McLead, J. D. 1973. Fossils of the Warsaw Limestone. Earth Science, 26:243, 247.

Meeк, F. B. 1872. Preliminary list of the fossils collected by Dr. Hayden's exploring expedition of 1871, in Utah and Wyoming territories, with descriptions of a few new species, p. 373377. In F. V. Hayden, Preliminary report of the U.S. Geological Survey of Montana and portions of adjacent territories, preliminary report (fifth annual) (1871).

Meек, F. B, 1874. Notes on some of the fossils figured in the recently issued fifth volume of the Illinois State Geological Report. American Journal of Science, ser. 3, 7:189-193, 369-376, 484-488.

Meek, F. B. And A. H. Worthen. 1860. Descriptions of new species of crinoidea and echinoidea from the Carboniferous rocks of Illinois, and other western states. Proceedings of the Academy of Natural Sciences of Philadelphia, 12:379-397.

Meek, F. B. And A. H. Worthen. 1861. Descriptions of new Palaeozoic fossils from Illinois and Iowa. Proceedings of the Academy of Natural Sciences of Philadelphia, 13:128-148.

Meek, F. B. And A. H. Worthen. 1865a. Descriptions of new species of crinoidea, etc. from the Paleozoic rocks of Illinois and some of the adjoining states. Proceedings of the Academy of Natural Sciences of Philadelphia, 17:143-155.

Meek, F. B. And A. H. Worthen. 1865b. Descriptions of new crinoidea, etc. from the Carboniferous rocks of Illinois and some of the adjoining states. Proceedings of the Academy of Natural Sciences of Philadelphia, 17:155-166. 
Meek, F. B. And A. H. Worthen. 1866a. Descriptions of invertebrates from the Carboniferous system. Illinois Geological Survey, 2(2):143-411.

Meek, F. B. And A. H. Worthen. 1866b. Contributions to the palaeontology of Illinois and other western states. Proceedings of the Academy of Natural Sciences of Philadelphia (1865), $17: 251-274$.

Meek, F. B. And A. H. Worthen. 1868a. Remarks on some types of Carboniferous crinoidea, with descriptions of new genera and species of the same, and of one echinoid. Proceedings of the Academy of Natural Sciences of Philadelphia, 20:335-359.

Meek, F. B. And A. H. Worthen. 1868b. Palaeontology of Illinois. Illinois Geological Survey, 3(2):289-565.

Meek, F. B. And A. H. Worthen. 1869. Descriptions of new Carboniferous fossils from the western States. Proceedings of the Academy of Natural Sciences of Philadelphia, 22:137172.

Meek, F. B. And A. H. Worthen. 1870. Descriptions of new Carboniferous fossils from the western States. Proceedings of the Academy of Natural Sciences of Philadelphia, 21:137172.

Meek, F. B. And A. H. Worthen. 1873. Palaeontology, Descriptions of invertebrates from Carboniferous System. Illinois Geological Survey, 5(2):323-619.

Miller, J. S. 1821. A natural history of the Crinoidea, or lily-shaped animals; with observations on the genera, Asteria, Euryale, Comatula and Marsupites. Bryan \& Co., Bristol, England, $150 \mathrm{p}$.

Miller, S. A. 1881. Subcarboniferous fossils from the Lake Valley Mining District of New Mexico, with descriptions of new species. Journal of the Cincinnati Society of Natural History, 4(4):306-315.

Miller, S. A. 1889. North American geology and paleontology. Western Methodist Book Concern, Cincinnati, 664 p.

Miller, S. A. 1890. The structure, classification and arrangement of American Palaeozoic crinoids into families. American Geologist, 6:275-286, 340-357.

Miller, S. A. 1891a. A description of some Lower Carboniferous crinoids. Geological Survey of Missouri Bulletin 4, 40 p.

Miller, S. A. 1891b. Palaeontology. Advance sheets. Indiana Department of Geology and Natural Resources, 17th Annual Report, 103 p. 
Miller, S. A. 1892a. North American geology and paleontology, first appendix. Cincinnati, Western Methodist Book Concern, p. 665-718.

Miller, S. A. 1892b. Palaeontology. Advance sheets, Indiana Department of Geology and Natural Resources, 18th Annual Report, 79 p.

Miller, S. A. 1894. Palaeontology: Indiana Department of Geology and Natural Resources, 18th Annual Report (1893), p. 257-356.

Miller, S. A. 1897. Second appendix to North American geology and palaeontology. Western Methodist Book Concern, Cincinnati, p.719-793.

Miller, S. A. And W. F. E. Gurley. 1890. Description of some new genera and species of Echinodermata from the Coal Measures and Subcarboniferous rocks of Indiana, Missouri, and Iowa. Journal Cincinnati Society of Natural History, 13(1):1-25.

Miller, S. A. And W. F. E. Gurley. 1893. Description of some new species of invertebrates from the Palaeozoic rocks of Illinois and adjacent states. Illinois State Museum Bulletin 3, 81 p.

Miller, S. A. And W. F. E. Gurley. 1894. New genera and species of Echinodermata. Illinois State Museum Bulletin 5, 53 p.

Miller, S. A. And W. F. E. Gurley. 1895a. Description of new species of Palaeozoic Echinodermata. Illinois State Museum Bulletin 6, 62 p.

Miller, S. A. And W. F. E. Gurley. 1895b. New and interesting species of Palaeozoic fossils. Illinois State Museum Bulletin 7, 89 p.

Miller, S. A. And W. F. E. Gurley. 1896a. Description of new and remarkable fossils from the Palaeozoic rocks of the Mississippi Valley. Illinois State Museum Bulletin 8, 65 p.

Miller, S. A. And W. F. E. Gurley. 1896b. New species of Crinoids from Illinois and other states. Illinois State Museum Bulletin 9, 66 p.

Miller, S. A. And W. F. E. Gurley. 1896c. New species of Echinodermata and a new crustacean from the Palaeozoic rocks. Illinois State Museum Bulletin 10, 91 p.

Miller, S. A., And W. F. E. Gurley. 1897. New species of crinoids, cephalopods, and other Palaeozoic fossils. Illinois State Museum Bulletin 12, 69 p.

Moore, R. C. 1939. The use of fragmentary crinoidal remains in stratigraphic paleontology. Denison University Bulletin, Journal of the Scientific Laboratories, 33:165-250. 
Moore, R. C. 1952. Evolution rates among crinoids. Journal of Paleontology, 26:338-352.

Moore, R. C. AND L.R. Laudon. 1942. Megaliocrinus, a new camerate crinoid genus from the Morrow Series of northeastern Oklahoma. Denison University Bulletin, Journal of the Scientific Laboratories, 37:67-76.

Moore, R. C. And L.R. Laudon. 1943. Evolution and classification of Paleozoic crinoids. Geological Society of America Special Paper 46, 151p.

Moore, R. C. and L.R. Laudon. 1944. Class Crinoidea, p. 137-209. In H. W. Shimer and R. R. Shrock, Index fossils of North America. John Wiley and Sons, Inc., New York.

MüNSTER, G. G. 1839-1846. Beschreibung einiger neuen Crinoideen aus der Uebergangsformation. Beitrage zur Petrefacten-Kunde, 7 vols.

Neumayr, M. 1889. Die Stämme des Thierreiches, Band 1, Wirbellose Thiere. Verlag von F. Tempsky \& Tempsky, Wien, Prag, 6, 603 p.

Owen, D. D. and B. F. Shumard. 1850. Descriptions of fifteen new species of Crinoidea from the Subcarboniferous limestone of Iowa, Wisconsin and Minnesota in the years 1848-1849. Journal of the Academy of Natural Sciences of Philadelphia, series 2, 2:57-70.

Owen, D. D. and B. F. Shumard. 1852. Descriptions of seven new species of crinoidea from the subcarboniferous of Iowa and Illinois. Journal of the Academy of Natural Sciences of Philadelphia, series 2, 2:89-94.

Peck, R. E. and I. A. Keyte. 1938. The Crinoidea of the Chouteau Limestone. In E. B. Branson (ed), Stratigraphy and paleontology of the Lower Mississippian of Missouri, Pt. 2: Missouri University Studies, 13(4):70-108.

PhiLLIPS, J. 1836. Illustrations of the geology of Yorkshire, or a description of the strata and organic remains, Pt. 2, The Mountain Limestone districts, 2nd edition. John Murray, London: 203-208.

PraY, L. C. 1961. Geology of the Sacramento Mountains escarpment, Otero County, New Mexico. Bulletin - New Mexico Bureau of Geology \& Mineral Resources, 144 p.

Quenstedt, F. A. 1867. Handbuch der Petrefactenkunde: 2nd edition. H. Laupp Verlag, Tubingen, $1239 \mathrm{p}$.

Quenstedt, F. A. 1874-76. Petrefactenkunde Deutschlands, Erst Abtheilung, Vierter (4) Band, Echinodermen (Asteriden und Encriniden). p. 1-742 (1876); Atlas zu den Echiniden, pl. 6289 (1874); Atlas zu den Asteriden und Encriniden, pl. 90-114 (1876), Fues's Verlag, Leipzig. 
Quenstedt, F. A. 1885. Handbuch der Petrefactenkunde. 3rd edition. H. Laupp Verlag, Tübingen, 2 vols, 1237p.

Roemer, C. F. 1852-54. Erste Periode, Kohlen-Gebirge, p. 210-291. In H. G. Bronn, Lethaea Geognostica, 1851-1856, 3rd edit. E. Schweizerbart, Stuttgart, 2.

ROEMER, C. F. 1876.

Rose, J. N. 1967. Fossils and rocks of eastern Iowa. Iowa Geological Survey, Educational Ser. v. $1,146 \mathrm{p}$.

Rowley, R. R. AND S. J. Hare. 1891. Description of some new species of crinoids and blastoids from the Sub-carboniferous rocks of Pike and Marion Counties, Mo., and Scott County, Va. Kansas City Scientist, 5(8):113-118.

SснміDт, H. 1929 Tierische Leitfossilien des Karbon. In G. Gürich (ed), Leitfossilien: Gebrüder Borntraeger, Berlin, pt. 6, 107p.

Shumard, B. F. 1855. Description of new species of organic remains. Missouri Geological Survey, 2:185-208.

Shumard, B. F. 1865-1866. Catalogue of Palaeozoic fossils, Part 1, Echinodermata. Transactions of the St. Louis Academy Science, 2(2):334-394, 1865; 395-407, 1866.

Shumard, B. F. 1868. A catalogue of the Palaeozoic fossils of North America: Part I, Paleozoic Echinodermata: Transactions of the St. Louis Academy of Science (1866), 2:334-407.

SIEVERTs-DoReCK, H. 1952. Über die sogenannten "Deckplättchen" gotlandischer Cyathocrinidae. Neues Jahrbuch für Geologie und Paläontologie, Monatschefte, 9:420-430.

SpRENG, W. P. AND J. M. Parks. 1953. Evolution in basal plates of monocyclic camerate crinoids. Journal of Paleontology, 27:585-595.

SpRINGER, F. 1884. On the occurrence of the lower Burlington limestone in New Mexico. American Journal of Science, 27:97-103.

Springer, F. 1913. Crinoidea, p. 173-243. In K. A. von Zittel, Text-book of paleontology (translated and edited by C. R. Eastman). 2nd edition, Macmillan \& Co., Ltd., London.

Steinmann, G. 1903. Einführung in die Paläontologie. W. Engelmann, Leipzig, 466 p.

Steinmann, G. 1907. Einführung in die Paläontologie. W. Engelmann, 2nd edit, Leipzig, 542 p. 
Steinmann, G. and L. Döderlein. 1890. Elemente der Paläontologie. v. 5. Klasse: Crinoidea. Leipzig, p. 149-176.

StRimple, H. L. And J. W. Koenig. 1956. Mississippian microcrinoids from Oklahoma and New Mexico. Journal of Paleontology, 30:1225-1247.

Ubaghs, G. 1953. Classe des Crinoides, p. 658-773. In Piveteau, J., ed, Traité de paléontologie: Paris, Masson \& Cie, v. 3.

Ubaghs G. 1978a. Skeletal Morphology of Fossil Crinoids, p. T59-T216. In R. C. Moore and K. Teichert (eds.), Treatise on Invertebrate Paleontology, Echinodermata, Pt. T(1). Geological Society of America and University of Kansas Press, Boulder and Lawerence.

Ubaghs G. 1978b. Camerata, p. T408-T519. In R. C. Moore and K. Teichert (eds.), Treatise on Invertebrate Paleontology, Echinodermata, Pt. T(2). Geological Society of America and University of Kansas Press, Boulder and Lawerence.

VAn TuYL, F. M. 1925. The stratigraphy of the Mississippian formations of Iowa. Geological Survey Iowa, 30th Annual Report (1921-1922), p. 33-374.

Wachsmuth, C., 1896. Class Crinoidea. In K. A. von Zittel, Text-book of palaeontology (18961900), C. R. Eastman (ed. and translator). Macmillian London, New York, Macmillan, v. 1, p. 124-177.

Wachsmuth, C. and F. Springer. 1878. Transition-forms in crinoids and descriptions of 5 new species. Proceedings of the Academy of Natural Sciences of Philadelphia, 29:224-266.

Wachsmuth, C. and F. Springer. 1880-1886. Revision of the Palaeocrinoidea. Proceedings of the Academy of Natural Sciences of Philadelphia Pt. I. The families Ichthyocrinidae and Cyathocrinidae (1880):226-378, (separate repaged p. 1-153); Pt. II. Family Sphaeroidocrinidae, with the sub-families Platycrinidae, Rhodocrinidae, and Actinocrinidae (1881):177-411 (separate repaged, p. 1-237); Pt. III, Sec. 1. Discussion of the classification and relations of the brachiate crinoids, and conclusion of the generic descriptions (1885):225364 (separate repaged, p. 1-138); Pt. III, Sec. 2. Discussion of the classification and relations of the brachiate crinoids, and conclusion of the generic descriptions (1886):64-226 (separate repaged to continue with section $1,139-302)$.

Wachsmuth, C. and F. Springer. 1889. Discovery of the ventral structure of Taxocrinus and Haplocrinus, and consequent modifications in the classifications of the crinoidea. Proceedings of the Academy of Natural Sciences of Philadelphia, 40:337-363.

Wachsmuth, C. and F. Springer. 1890. New species of crinoids and blastoids from the Kinderhook Group of the Lower Carboniferous rocks at LeGrand, Iowa, and a new genus 
from the Niagaran Group of Western Tennessee. Illinois Geological Survey, v. 8, pt. 2, Palaeontology of Illinois, sec. 2, p. 155-206.

Wachsmuth, C. and F. SpRinger. 1897. The North American Crinoidea Camerata. Harvard College Museum of Comparative Zoology Memoirs, 20 and 21, 897 p.

Webster, G. D. 1973. Bibliography and index of Paleozoic crinoids, 1942-1968. Geological Society of America Memoir 137, 341p.

WeBster, G. D. 1977. Bibliography and index of Paleozoic crinoids, 1969-1973. Geological Society of America Microform Publication 8, 235 p.

Webster, G. D. 1986. Bibliography and index of Paleozoic crinoids, 1974-1980. Geological Society of America Microform Publication 16, 405 p.

Webster, G. D. 1988. Bibliography and index of Paleozoic crinoids and coronate echinoderms 1981-1985. Geological Society of America Microform Publication 18, 235p.

WeBster, G. D. 1993. Bibliography and index of Paleozoic crinoids, 1986-1990. Geological Society of America Microform Publication 25, 204 p.

Webster, G. D. 2003. Bibliography and index of Paleozoic crinoids, coronates, and hemistreptocrinoids 1758-1999. Geological Society of America Special Paper 363, $<$ http://crinoid.gsajournals.org/crinoidmod/>

Webster, G. D. and N. G. Lane. 1987. Crinoids from the Anchor Limestone (Lower Mississippian) of the Monte Cristo Group Southern Nevada. University of Kansas Paleontological Contributions Paper, 119, 55 p.

WeLler, S. 1898. A bibliographic index of Carboniferous invertebrates. U. S. Geological Survey Bulletin 153, 653 p.

WiLson, H. E. 1916. Evolution of the basal plates in monocyclic Crinoidea Camerata. Journal of Geology, 24:488-510, 533-553, 665-684.

WhiтE, C. A. 1862. Description of new species of fossils from the Devonian and Carboniferous rocks of the Mississippi Valley. Boston Society of Natural History Journal, 9:8-33.

White, C. A. 1865. Description of new species of fossils from the Devonian and Carboniferous rocks of the Mississippi Valley. Boston Society of Natural History Journal, 9:8-33.

Whitfield, R. P. 1881. Description of a new species of crinoid from the Burlington Limestone, at Burlington, Iowa. American Museum of Natural History Bulletin, 1:7-11. 
WhITFIELD, R. P. 1893. Republication of descriptions of Lower Carboniferous Crinoidea from the Hall collection now in the American Museum Natural History with illustrations of the original type specimens not heretofore figured. American Museum of Natural History Memoir, 1(1), 37.

Wolf, R. C. 1979. Hunting Iowa's crinoids. Earth Science, 32(4):149-151.

Wright, J. 1950-1960. The British Carboniferous Crinoidea. Palaeontographical Society, Monograph, 1(1):1-24, 1950; 1(2):25-46, 1951a; 1(3):47-102, 1951b; 1(4:103-148, 1952a; 1(5):149-190,1954a; 2(1):191-254, 1955a; 2(2):255-272, 1955b; 2(3):273-306, 1956b; 2(4):307-328,1958; 2(5):329-347 1960.

Zitтé, K. A. Von. 1876-80. Handbuch der Palaeontologie, v. 1, Palaeozoologie, R. Oldenbourg, München, Leipzig, 765p.

Zittel, K. A. Von. 1895. Grundzüge der Palaeontologie (Palaeozoologie), 1st edition, R. Oldenbourg, München, 971 p. 
TABLE 1.1.- Distribution of Lake Valley Formation crinoid species as they occur elsewhere according to Webster (2003). Kinderhookian formations include the Choteau Limestone and Compton Limestone in Missouri, the Hampton Formation in Iowa, and the Cuyahoga Formation of Ohio. Osagean formations include Fern Glenn Limestone in Missouri, Burlington Limestone (separated into lower and upper to distinguish what is equivalent to the Nunn Member (lower Burlington) and which is younger) in Iowa, lower Warsaw Formation in Illinois, Borden Formation in Kentucky, St. Joe Limestone and Boone Formation in Arkansas, Redwall Limestone in Arizona, and the Anchor Limestone in Nevada. Three species have only been reported in the Lake Valley Formation and are represented as such. Five species were specified as only being found in the Burlington Limestone with no indication as to whether it is the lower or the upper part; these are marked with $\mathrm{xx}$.

\begin{tabular}{|c|c|c|c|c|c|c|c|c|c|c|c|c|c|c|}
\hline & \multicolumn{4}{|c|}{ Kinderhookian } & \multicolumn{10}{|c|}{ Osagean } \\
\hline & 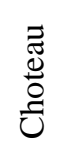 & 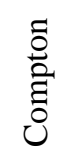 & 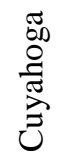 & $\begin{array}{l}\text { ఫ्: } \\
\text { : } \\
\text { 壱 }\end{array}$ & 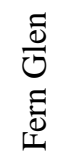 & $\begin{array}{l}\vec{\Xi} \\
\dot{\emptyset}\end{array}$ & $\begin{array}{l}\vec{\Xi} \\
\ddot{\emptyset} \\
\dot{D}\end{array}$ & $\begin{array}{l}3 \\
\text { 总 } \\
\stackrel{0}{6} \\
3\end{array}$ & $\begin{array}{l}\text { चี } \\
\overline{\tilde{D}} \\
0\end{array}$ & 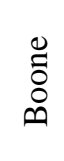 & $\begin{array}{l}\stackrel{8}{\circ} \\
\dot{\omega}\end{array}$ & 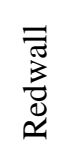 & $\begin{array}{l}\tilde{y} \\
\bar{y} \\
\dot{E}\end{array}$ & $\begin{array}{l}\frac{\lambda}{B} \\
0 \\
3 \\
3\end{array}$ \\
\hline Rhodocrinites tuberculatus & & & & & & & & & & & & & & $\mathrm{X}$ \\
\hline Cribanocrinus urceolatus & & & & & & & & & & & & $\mathrm{X}$ & & \\
\hline Aryballocrinus whitei & & & & $\mathrm{X}$ & & $\mathrm{X}$ & $\mathrm{X}$ & & & & & & & \\
\hline Aryballocrinus tenuidiscus & & & & & & $\mathrm{X}$ & & & & & & & & \\
\hline Amphoracrinus rubinus & & & & & & & & & & & & & $\mathrm{X}$ & \\
\hline Ancalocrinus spinobrachiatus & & & & & & $\mathrm{X}$ & & & & & & & $\mathrm{X}$ & \\
\hline Displodocrinus divergens & & & $\mathrm{X}$ & & & $\mathrm{X}$ & & & & & & & $\mathrm{X}$ & \\
\hline Displodocrinus nevadensis & & & & & & & & & & & & & $\mathrm{X}$ & \\
\hline Aacocrinus nododorsatus & $\mathrm{X}$ & $\mathrm{X}$ & & & & & & & & & & & & \\
\hline Aacocrinus enigmaticus & & & & & & & & & & & & & $\mathrm{X}$ & \\
\hline Steganocrinus pentagonus & & & & & $\mathrm{X}$ & $\mathrm{X}$ & & & & & & & & \\
\hline Cactocrinus proboscidalis & $\mathrm{X}$ & & & & & $\mathrm{X}$ & & & & & & & & \\
\hline Cactocrinus multibrachiatus & & & & & & $\mathrm{X}$ & & & & & & & & \\
\hline Cusacrinus sobrinus & & & & & & $\mathrm{xx}$ & $\mathrm{xx}$ & & & & & & & \\
\hline Cusacrinus tenuisculptus & $\mathrm{X}$ & & & & & $\mathrm{xx}$ & $\mathrm{xx}$ & & & & & & & \\
\hline Nunnacrinus dalyanus & & & & & & & & & & & & & & $\mathrm{X}$ \\
\hline Teliocrinus umbrosus & & & & & & & $\mathrm{X}$ & & & & & & & \\
\hline Physetocrinus copei & & & & & & & & & & & & $\mathrm{X}$ & & \\
\hline Physetocrinus lobatus & & & & & & & & & & & & $\mathrm{X}$ & & \\
\hline Abatocrinus aequalis & $\mathrm{X}$ & & & & & $\mathrm{X}$ & & & & & & & & \\
\hline Abatocrinus clypeatus & $\mathrm{X}$ & & & & & $\mathrm{X}$ & & & & & & & & \\
\hline Eretmocrinus corbulis & & & & & & $\mathrm{X}$ & & & & & & & & \\
\hline Eutrochocrinus christyi & $\mathrm{X}$ & & & & $\mathrm{X}$ & & $\mathrm{X}$ & & & & $\mathrm{X}$ & & & \\
\hline Eutrochocrinus lovei & & & & & & & $\mathrm{X}$ & & & & & & & \\
\hline Agaricocrinus bullatus & & & & & & $\mathrm{X}$ & $\mathrm{X}$ & $\mathrm{X}$ & & & & & & \\
\hline Agaricocrinus planoconvexus & $\mathrm{X}$ & & & & & $\mathrm{X}$ & $\mathrm{X}$ & & $\mathrm{X}$ & & & & & \\
\hline Agaricocrinus pyramidatus & & & & & & $\mathrm{X}$ & & & & & & & & \\
\hline Dichocrinus conus & & & & & & $\mathrm{X}$ & $\mathrm{X}$ & & & $\mathrm{X}$ & & & & \\
\hline
\end{tabular}




\begin{tabular}{|c|c|c|c|c|c|c|c|c|c|c|c|c|c|c|}
\hline & \multicolumn{4}{|c|}{ Kinderhookian } & \multicolumn{10}{|c|}{ Osagean } \\
\hline & 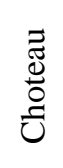 & $\begin{array}{l}\text { : } \\
\text { : } \\
\text { ல் }\end{array}$ & 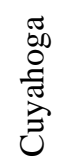 & 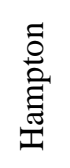 & 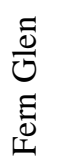 & $\begin{array}{l}\vec{\Xi} \\
\dot{\emptyset} \\
\dot{\omega}\end{array}$ & $\begin{array}{l}\vec{\Xi} \\
\dot{\varphi} \\
\dot{\omega}\end{array}$ & 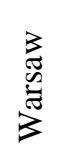 & 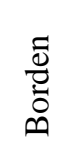 & : & $\begin{array}{l}\stackrel{\Xi}{\circ} \\
\dot{\omega}\end{array}$ & 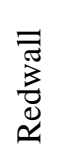 & 茅 & 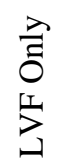 \\
\hline Strimplecrinus pisum & & & & & & $\mathrm{X}$ & & & & & & & & \\
\hline Platycrinites burlingtonensis & & & & & & $\mathrm{X}$ & & & & & & & & \\
\hline Platycrinites illinoisensis & & & & & & $\mathrm{xx}$ & $\mathrm{xx}$ & & & & & & & \\
\hline Platycrinites parvinodus & & & & & & $\mathrm{X}$ & & & & & & & & \\
\hline Platycrinites pecularius & & & & & & & & & & & & & & $\mathrm{X}$ \\
\hline Collicrinus shumardi & & & & & & $\mathrm{X}$ & & & & & & & & \\
\hline Elegantocrinus annosus & $\mathrm{X}$ & & & & & & & & & & & & & \\
\hline Elegantocrinus canaliculatus & & & & & & $\mathrm{X}$ & $\mathrm{X}$ & & & & & & & \\
\hline Elegantocrinus nodostriatus & & & & & & & $\mathrm{X}$ & & & & & $\mathrm{X}$ & & \\
\hline Elegantocrinus pileiformis & $\mathrm{X}$ & & & & & $\mathrm{X}$ & & & & & & & & \\
\hline Elegantocrinus pocilliformis & & & & & & $\mathrm{X}$ & & & & & & & & \\
\hline Eucladocrinus pleuroviminus & & & & & & & $\mathrm{X}$ & & & & & & & \\
\hline Oenochoacrinus limbus & & & & & & & & & & & & & $\mathrm{X}$ & \\
\hline Oenochoacrinus cortina & $\mathrm{X}$ & & & & & & & & & & & & & \\
\hline Pleurocrinus quiquenodus & & & & & & $\mathrm{xx}$ & $\mathrm{xx}$ & & & & & & & \\
\hline Plemnocrinus bullatus & & & & & & $\mathrm{xx}$ & $\mathrm{xx}$ & & & & & & & \\
\hline Plemnocrinus homalus & & & & & & $\mathrm{X}$ & & & & & & & & \\
\hline Plemnocrinus subspinosus & & & & & & & $\mathrm{X}$ & & & & & & & \\
\hline Counts & 10 & 1 & 1 & 1 & 2 & 27 & 16 & 1 & 1 & 1 & 1 & 4 & 6 & 3 \\
\hline
\end{tabular}


TABLE 1.2.-Measurements of Blairocrinus macurdai n. sp. (in mm); holotype indicated by asterisk.

\begin{tabular}{|c|c|c|c|c|c|c|c|c|c|}
\hline & \multirow{2}{*}{$\frac{\text { Crown }}{\mathrm{H}}$} & \multirow{2}{*}{$\begin{array}{c}\text { Aboral } \\
\text { Cup } \\
\mathrm{H}\end{array}$} & \multirow{2}{*}{$\begin{array}{c}\begin{array}{c}\text { Calyx } \\
(\mathrm{A}-\mathrm{CD})\end{array} \\
\mathrm{W}\end{array}$} & \multicolumn{2}{|c|}{ Basal } & \multicolumn{2}{|c|}{ Radial } & \multicolumn{2}{|c|}{ Primanal } \\
\hline & & & & $\mathrm{H}$ & $\mathrm{W}$ & $\mathrm{H}$ & $\mathrm{W}$ & $\mathrm{H}$ & $\mathrm{W}$ \\
\hline UMMP 74065* & 21.2 & 6.8 & 20.4 & 2.2 & 2.8 & 3.1 & 3.8 & 2.8 & 3.8 \\
\hline UMMP 74066 & 17.7 & 5.3 & 20.0 & - & - & - & - & - & - \\
\hline UMMP 74067 & 12.5 & 3.2 & 13.5 & 1.0 & 3.1 & 1.5 & 2.5 & 1.8 & 1.6 \\
\hline
\end{tabular}


TABLE 1.3.- Comparison of diagnostic characters of Blairocrinus macurdai $\mathrm{n}$. sp. with other known species of the genus.

\begin{tabular}{|c|c|c|c|c|}
\hline & B. trijugis & B. arrosus & B. protubertus & B. macurdai \\
\hline Calyx & low bowl & low bowl & low cone & low bowl \\
\hline Basals & $\begin{array}{l}\text { small, form flat horizontal } \\
\text { disk }\end{array}$ & $\begin{array}{c}\text { small, project } \\
\text { slightly from column }\end{array}$ & $\begin{array}{l}\text { small, barely visible } \\
\text { in lateral view }\end{array}$ & $\begin{array}{c}\text { small, visible in lateral } \\
\text { view }\end{array}$ \\
\hline Radials & $\begin{array}{l}\text { large, nearly as wide as } \\
\text { long; stellate }\end{array}$ & $\begin{array}{l}\text { little wider than } \\
\text { long; has transverse } \\
\text { nodes }\end{array}$ & large; elongate nodes & $\begin{array}{l}\text { wider than high; } \\
\text { stellate }\end{array}$ \\
\hline Primibrachials & $\begin{array}{c}\text { 1st quadrangular wider } \\
\text { than long; 2nd larger than } \\
\text { 1st }\end{array}$ & $\begin{array}{l}\text { 1st quadrangular, } \\
\text { wider than long; 2nd } \\
\text { axillary, larger than } \\
\text { first }\end{array}$ & $\begin{array}{l}\text { 1st pentagonal or } \\
\text { hexagonal; 2nd } \\
\text { axillary, same size as } \\
\text { first }\end{array}$ & $\begin{array}{l}\text { 1st hexagonal, wider } \\
\text { than high; 2nd } \\
\text { axillary, same size as } \\
\text { first }\end{array}$ \\
\hline Secundibrachials & one per half-ray & one per half-ray & one per half-ray & one per half-ray \\
\hline Anals & $\begin{array}{c}\text { Primanal smaller than } \\
\text { radials; } 1 ; 2 ; 2 ; 2 \text {. Anal tube } \\
\text { central, stout }\end{array}$ & $\begin{array}{l}\text { Primanal as large as } \\
\text { radials; } 1 ; 2 ; 2 \text {. Anal } \\
\text { tube central, stout }\end{array}$ & $\begin{array}{l}\text { Primanal same size } \\
\text { as radials; } 1 ; 2 ; 3 ; 3 . \\
\text { Anal tube slightly } \\
\text { eccentric, narrow }\end{array}$ & $\begin{array}{l}\text { Primanal smaller than } \\
\text { radial; } 1 ; 2 ; 3 ; 2 ; 2 \text {. Anal } \\
\text { tube central to slightly } \\
\text { eccentric, stout }\end{array}$ \\
\hline Tegmen & $\begin{array}{l}\text { low inverted bowl; large } \\
\text { spines on ambulacral } \\
\text { plates, rest smooth }\end{array}$ & $\begin{array}{l}\text { low to medium } \\
\text { inverted bowl; plates } \\
\text { nodose to spinose }\end{array}$ & $\begin{array}{l}\text { flat or very low cone; } \\
\text { plates low spines or } \\
\text { smooth }\end{array}$ & $\begin{array}{l}\text { medium cone; plates } \\
\text { spinose to nodose }\end{array}$ \\
\hline
\end{tabular}


TABLE 1.4.-Measurements of Iotacrinus novamexicana n. sp. (in mm); holotype indicated by asterisk.

\begin{tabular}{|c|c|c|c|c|c|c|c|c|c|}
\hline & \multirow{2}{*}{$\begin{array}{c}\text { Crown } \\
\mathrm{H}\end{array}$} & \multirow{2}{*}{$\begin{array}{c}\begin{array}{c}\text { Aboral } \\
\text { Cup }\end{array} \\
\mathrm{H} \\
\end{array}$} & \multirow{2}{*}{$\begin{array}{c}\begin{array}{c}\text { Calyx } \\
(\mathrm{A}-\mathrm{CD})\end{array} \\
\mathrm{W}\end{array}$} & \multicolumn{2}{|c|}{ Basal } & \multicolumn{2}{|c|}{ Radial } & \multicolumn{2}{|c|}{ Primanal } \\
\hline & & & & $\mathrm{H}$ & $\mathrm{W}$ & $\mathrm{H}$ & $\mathrm{W}$ & $\mathrm{H}$ & $\mathrm{W}$ \\
\hline UMMP 74068* & 15.5 & 5.7 & 14.3 & 1.0 & 3.8 & 2.8 & 3.7 & 2.2 & 2.7 \\
\hline UMMP 74069 & 16.8 & 7.1 & 16.7 & 1.4 & 4.0 & 2.5 & 4.2 & 2.6 & 2.6 \\
\hline UMMP 74070 & 17.2 & 6.5 & 14.6 & 1.4 & 3.5 & 3.2 & 4.0 & 2.5 & 3.0 \\
\hline
\end{tabular}


TABLE 1.5.-Comparison of diagnostic characters of Iotacrinus novamexicana n. sp. with other known species of the genus.

\begin{tabular}{|c|c|c|}
\hline & I. dorsatus & I. novamexicana \\
\hline Calyx & low bowl & low bowl \\
\hline Basals & small, visible in lateral view & small, visible in lateral view \\
\hline Radials & $\begin{array}{l}\text { hexagonal or heptagonal, wider } \\
\text { than high; stellate }\end{array}$ & $\begin{array}{l}\text { hexagonal, wider than high; } \\
\text { stellate }\end{array}$ \\
\hline Primibrachials & $\begin{array}{l}\text { 1st wider than high; 2nd } \\
\text { axillary, smaller than 1st }\end{array}$ & $\begin{array}{l}\text { 1st hexagonal, wider than high; } \\
\text { 2nd axillary, slighty smaller than } \\
\text { 1st }\end{array}$ \\
\hline Secundibrachials & one per half-ray & one per half-ray \\
\hline Anals & $\begin{array}{l}\text { Primanal narrower than radials; } \\
\text { 1;2;3 or } 1 ; 2 ; 3 ; 2 \text {. Anal tube } \\
\text { eccentric, long }\end{array}$ & $\begin{array}{l}\text { Primanal narrower than radials; } \\
1 ; 2 ; 3 \text {. Anal tube eccentric, stout }\end{array}$ \\
\hline Tegmen & $\begin{array}{l}\text { flat to low bowl; approximately } \\
\text { as high as calyx; plates nodose }\end{array}$ & $\begin{array}{l}\text { medium to low inverted bowl; as } \\
\text { high as or slightly higher than } \\
\text { calyx; plates smooth to slightly } \\
\text { nodose }\end{array}$ \\
\hline
\end{tabular}


TABLE 1.6.-Measurements of Uperocrinus kuesi n. sp. (in mm).

\begin{tabular}{|c|c|c|c|c|c|c|c|c|c|}
\hline & \multirow{2}{*}{$\frac{\text { Crown }}{\mathrm{H}}$} & \multirow{2}{*}{$\begin{array}{c}\begin{array}{c}\text { Aboral } \\
\text { Cup }\end{array} \\
\mathrm{H}\end{array}$} & \multirow{2}{*}{$\begin{array}{c}\begin{array}{c}\text { Calyx } \\
(\mathrm{A}-\mathrm{CD})\end{array} \\
\mathrm{W}\end{array}$} & \multicolumn{2}{|c|}{ Basal } & \multicolumn{2}{|c|}{ Radial } & \multicolumn{2}{|c|}{ Primanal } \\
\hline & & & & $\mathrm{H}$ & W & $\mathrm{H}$ & $\mathrm{W}$ & $\mathrm{H}$ & $\mathrm{W}$ \\
\hline UMMP 74071 & 29.4 & 14.8 & 28.0 & 4.5 & 9.0 & 5.7 & 8.2 & 8.6 & 7.1 \\
\hline
\end{tabular}


TABLE 1.7.-Comparison of diagnostic characters of the most similar species to Uperocrinus kuesi n. sp. as well as the type species.

\begin{tabular}{|c|c|c|c|c|}
\hline & U. pyriformis & U. hageri & U. marinus & U. kuesi \\
\hline Calyx & medium cone & $\begin{array}{c}\text { low cone to low } \\
\text { bowl }\end{array}$ & medium cone & medium cone \\
\hline Basals & wider than long & rounded at bottom & $\begin{array}{l}\text { wider than high, } \\
\text { sutures grooved, } \\
\text { trilobate outline }\end{array}$ & $\begin{array}{l}\text { wider than high, } \\
\text { sutures grooved, } \\
\text { trilobate outline }\end{array}$ \\
\hline Radials & $\begin{array}{l}\text { large, higher than } \\
\text { wide, no } \\
\text { ornamentation }\end{array}$ & $\begin{array}{c}\text { higher than wide, no } \\
\text { ornamentation }\end{array}$ & $\begin{array}{l}\text { higher than wide, } \\
\text { prominent node in } \\
\text { center }\end{array}$ & $\begin{array}{l}\text { wider than high, } \\
\text { prominent node in } \\
\text { center }\end{array}$ \\
\hline Primibrachials & $\begin{array}{c}\text { 1st small, } \\
\text { quadrangular; 2nd } \\
\text { axillary, wider than } \\
\text { 1st }\end{array}$ & $\begin{array}{c}\text { 1st quadrangular, } \\
\text { wider than long; 2nd } \\
\text { axillary, wider than } \\
\text { 1st }\end{array}$ & $\begin{array}{c}\text { 1st quadrangular, } \\
\text { wider than long; } 2 \text { nd } \\
\text { axillary, wider than } \\
\text { 1st }\end{array}$ & $\begin{array}{l}\text { 1st hexagonal, wider } \\
\text { than long; } 2 \text { nd } \\
\text { axillary, smaller } \\
\text { than 1st; both have } \\
\text { central node }\end{array}$ \\
\hline Secundibrachials & $\begin{array}{c}\text { one per half-ray, } \\
\text { supports tertibrachs, } \\
\text { which support arm } \\
\text { facets }\end{array}$ & $\begin{array}{l}\text { two per half-ray; } \\
\text { support arm facets }\end{array}$ & $\begin{array}{l}\text { two per half-ray; } \\
\text { support arm facets }\end{array}$ & $\begin{array}{l}\text { two per half-ray; } \\
\text { supports arm facets; } \\
\text { both with central } \\
\text { node }\end{array}$ \\
\hline Anals & $\begin{array}{l}\text { Primanal as large as } \\
\text { radials; } 1 ; 3 ; 3 ; 1-2 . \\
\text { Anal tube long, } \\
\text { central, heavy }\end{array}$ & $\begin{array}{l}\text { Primanal little } \\
\text { smaller than radials; } \\
\text { 1;3;3;2;2. Anal tube } \\
\text { eccentric, very } \\
\text { narrow, short }\end{array}$ & $\begin{array}{c}\text { Primanal higher and } \\
\text { narrower than } \\
\text { radials; } 1 ; 3 ; 3 ; 2 ; 2 . \\
\text { Anal tube long, } \\
\text { heavy }\end{array}$ & $\begin{array}{c}\text { Primanal higher and } \\
\text { narrower than } \\
\text { radials; } 1 ; 3 ; 2 ; 1 . \\
\text { Anal tube eccentric, } \\
\text { very narrow }\end{array}$ \\
\hline Tegmen & $\begin{array}{l}\text { medium cone; same } \\
\text { height as to lower } \\
\text { than calyx, slightly } \\
\text { bulging; plates } \\
\text { nodose }\end{array}$ & $\begin{array}{l}\text { flat cone; lower than } \\
\text { calyx; plates smooth }\end{array}$ & unknown & $\begin{array}{l}\text { flat cone; lower than } \\
\text { calyx; plates convex }\end{array}$ \\
\hline
\end{tabular}


TABLE 1.8.-Measurements of Agaricocrinus alamogordoensis n. sp. (in mm).

\begin{tabular}{|c|c|c|c|c|c|c|c|c|c|}
\hline & \multirow{2}{*}{$\frac{\text { Crown }}{\mathrm{H}}$} & \multirow{2}{*}{$\begin{array}{c}\begin{array}{c}\text { Aboral } \\
\text { Cup }\end{array} \\
\mathrm{H}\end{array}$} & \multirow{2}{*}{$\begin{array}{c}\begin{array}{c}\text { Calyx } \\
\text { (A-CD) }\end{array} \\
\mathrm{W}\end{array}$} & \multicolumn{2}{|c|}{ Basal } & \multicolumn{2}{|c|}{ Radial } & \multicolumn{2}{|c|}{ Primanal } \\
\hline & & & & $\mathrm{H}$ & W & $\mathrm{H}$ & W & $\mathrm{H}$ & W \\
\hline UMMP 74072 & 17.5 & 6.1 & 15.7 & 2.0 & 4.0 & 3.2 & 4.8 & 3.9 & 3.4 \\
\hline
\end{tabular}


TABLE 1.9.-Comparison of diagnostic characters of the most similar species to Agaricocrinus alamogordoensis n. sp. as well as the type species.

\begin{tabular}{|c|c|c|c|c|c|c|}
\hline & A. tuberosus & A. brevis & A. convexus & A. coreyi & A. fiscellus & A. alamogordoensis \\
\hline Calyx & depressed bowl & $\begin{array}{l}\text { low bowl, } \\
\text { convex }\end{array}$ & low cone, convex & low bowl, convex & $\begin{array}{l}\text { low bowl, } \\
\text { convex }\end{array}$ & low cone, convex \\
\hline Basals & $\begin{array}{l}\text { small, hidden by } \\
\text { column }\end{array}$ & $\begin{array}{l}\text { Small, form } \\
\text { bottom of } \\
\text { column } \\
\text { depression }\end{array}$ & $\begin{array}{l}\text { small, in } \\
\text { depression, } \\
\text { hidden by } \\
\text { column }\end{array}$ & $\begin{array}{l}\text { small, on level } \\
\text { with radials }\end{array}$ & $\begin{array}{l}\text { Shallow } \\
\text { depression at } \\
\text { center for } \\
\text { column }\end{array}$ & $\begin{array}{c}\text { Small, form } \\
\text { concavity, edges } \\
\text { visibile in side view }\end{array}$ \\
\hline Radials & $\begin{array}{c}\text { as long as wide; } \\
\text { no } \\
\text { ornamentation }\end{array}$ & $\begin{array}{l}\text { little longer than } \\
\text { wide; ridges } \\
\text { occupy upper } \\
\text { end, convex } \\
\text { lower part } \\
\text { smooth }\end{array}$ & $\begin{array}{l}\text { large, as long as } \\
\text { wide; no } \\
\text { ornamentation }\end{array}$ & $\begin{array}{c}\text { large; wider than } \\
\text { long; no } \\
\text { ornamentation }\end{array}$ & $\begin{array}{l}\text { Wider than long, } \\
\text { upper part little } \\
\text { nodose, but w/o } \\
\text { ornamentation }\end{array}$ & $\begin{array}{l}\text { wider than hight, } \\
\text { prominent node in } \\
\text { center }\end{array}$ \\
\hline Primibrachials & $\begin{array}{l}\text { 1st small, } \\
\text { quadrangular; } \\
\text { 2nd axillary, } \\
\text { wider than 1st }\end{array}$ & $\begin{array}{l}\text { 1st small, } \\
\text { quadrangular, } \\
\text { convex sides. } \\
\text { 2nd axillary } \\
\text { shorter that 1st } \\
\text { but wider }\end{array}$ & $\begin{array}{l}\text { 1st quadrangular, } \\
\text { wider than long; } \\
\text { 2nd axillary, } \\
\text { wider than first }\end{array}$ & $\begin{array}{l}\text { 1st quadrangular, } \\
\text { wider than long; } \\
\text { 2nd axillary, } \\
\text { smaller than 1st }\end{array}$ & $\begin{array}{c}\text { 1st } \\
\text { quadrangular, } \\
\text { wider than long; } \\
\text { 2nd axillary, } \\
\text { wider than 1st }\end{array}$ & $\begin{array}{l}\text { 1st hexagonal, wider } \\
\text { than long; 2nd } \\
\text { axillary, same width } \\
\text { as } 1 \text { st }\end{array}$ \\
\hline Secundibrachials & one per half-ray & two per half-ray & two per half-ray & two per half-ray & two per half-ray & $\begin{array}{l}\text { one per half-ray, } \\
\text { supports one arm } \\
\text { facet apiece }\end{array}$ \\
\hline Anals & $\begin{array}{l}\text { Primanal higher } \\
\text { and narrower } \\
\text { than radials; } \\
\text { 1;3;3. Anal } \\
\text { opening directed } \\
\text { laterally }\end{array}$ & $\begin{array}{c}\text { Primanal little } \\
\text { narrower than } \\
\text { radials. 1;3;4- } \\
\text { 5;many. Well } \\
\text { defined grooves } \\
\text { on sides of anal } \\
\text { area. Anal } \\
\text { opening directed } \\
\text { laterally }\end{array}$ & $\begin{array}{c}\text { Primanal higher } \\
\text { and narrower } \\
\text { than radials; } \\
\text { 1;3;4-5;many; } \\
\text { shallow groove } \\
\text { on sides. Anal } \\
\text { opening directed } \\
\text { obliquely } \\
\text { upwards }\end{array}$ & $\begin{array}{l}\text { Primanal higher } \\
\text { and narrower } \\
\text { than radials; } \\
\text { 1;1;1. No } \\
\text { grooves. Anal } \\
\text { opening directed } \\
\text { obliquely } \\
\text { upwards }\end{array}$ & $\begin{array}{c}\text { As } A \text {. brevis but } \\
\text { more bulging }\end{array}$ & $\begin{array}{c}\text { Primanal higher and } \\
\text { narrower than } \\
\text { radials. } 1 ; 3 ; 3 ; 3 \text {. No } \\
\text { grooves. Anal } \\
\text { opening directed } \\
\text { laterally }\end{array}$ \\
\hline Tegmen & $\begin{array}{l}\text { much higher } \\
\text { than calyx }\end{array}$ & $\begin{array}{l}\text { same height as } \\
\text { calyx }\end{array}$ & lower than calyx & $\begin{array}{l}\text { Same height as } \\
\text { calyx }\end{array}$ & lower than calyx & $\begin{array}{l}\text { Same height as } \\
\text { calyx }\end{array}$ \\
\hline
\end{tabular}


TABLE 1.10.-Measurements of Collicrinus laudoni n. sp. (in mm).

\begin{tabular}{|c|c|c|c|c|c|c|c|}
\hline & \multirow{2}{*}{$\begin{array}{c}\text { Crown } \\
\mathrm{H}\end{array}$} & \multirow{2}{*}{$\begin{array}{c}\begin{array}{c}\text { Aboral } \\
\text { Cup }\end{array} \\
\mathrm{H} \\
\end{array}$} & \multirow{2}{*}{$\begin{array}{c}\begin{array}{c}\text { Calyx } \\
\text { (A-CD) }\end{array} \\
W \\
\end{array}$} & \multicolumn{2}{|c|}{ Basal } & \multicolumn{2}{|c|}{ Radial } \\
\hline & & & & $\mathrm{H}$ & $\mathrm{W}$ & $\mathrm{H}$ & W \\
\hline UMMP 74073 & 12.1 & 7.0 & 14.9 & 3.9 & 6.5 & 7.5 & 7.8 \\
\hline
\end{tabular}


TABLE 1.11.-Comparison of diagnostic characters of Collicrinus laudoni n. sp. with other known species of the genus.

\begin{tabular}{|c|c|c|c|}
\hline & C. shumardi & C. formosus & C. laudoni \\
\hline Calyx & flat bowl & low bowl & flat bowl \\
\hline Basals & $\begin{array}{l}\text { flat, not visible } \\
\text { in lateral view }\end{array}$ & $\begin{array}{l}\text { flat, within } \\
\text { basal } \\
\text { concavity, } \\
\text { nodes visible in } \\
\text { lateral view }\end{array}$ & $\begin{array}{l}\text { flat, visible in } \\
\text { lateral view }\end{array}$ \\
\hline Radials & $\begin{array}{l}\text { wider than } \\
\text { high, circular } \\
\text { to elongate } \\
\text { nodes crudely } \\
\text { aligned in rows }\end{array}$ & $\begin{array}{l}\text { wider than } \\
\text { high, nodose }\end{array}$ & $\begin{array}{c}\text { as wide as high, } \\
\text { smooth }\end{array}$ \\
\hline Anals & $\begin{array}{l}\text { Anal tube on } \\
\text { margin of } \\
\text { upper side of } \\
\text { tegmen }\end{array}$ & $\begin{array}{l}\text { Anal tube stout, } \\
\text { side of tegmen, } \\
\text { projects } \\
\text { outward or } \\
\text { obliquely } \\
\text { upward }\end{array}$ & $\begin{array}{c}\text { Anal tube } \\
\text { eccentric, } \\
\text { projects upward }\end{array}$ \\
\hline Tegmen & $\begin{array}{l}\text { low inverted } \\
\text { bowl, higher } \\
\text { than calyx; } \\
\text { plates large w/ } \\
\text { short spines }\end{array}$ & $\begin{array}{l}\text { as high as } \\
\text { calyx; plates } \\
\text { few, very } \\
\text { convex to } \\
\text { nodose }\end{array}$ & $\begin{array}{c}\text { low inverted } \\
\text { bowl, lower } \\
\text { than calyx; } \\
\text { plate large and } \\
\text { nodose }\end{array}$ \\
\hline
\end{tabular}




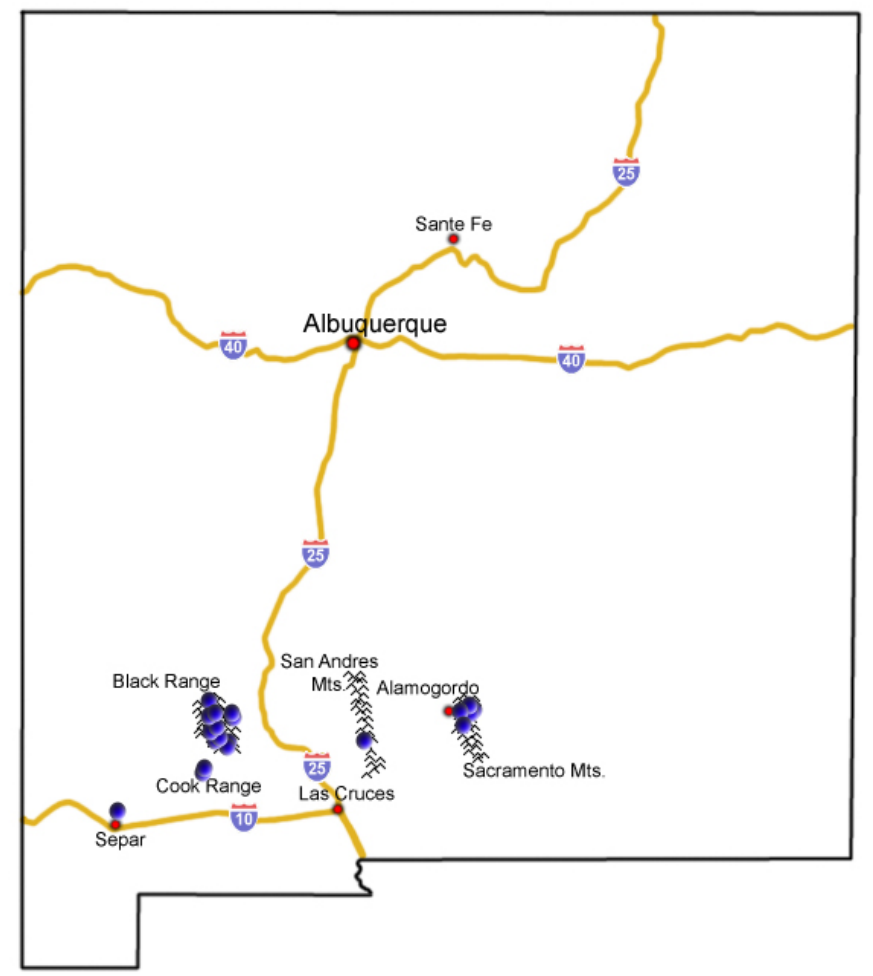

FiguRE 1.1.-Map of New Mexico showing the collecting sites for the Nunn Member. Most were collected by Dr. Brad Macurda. 


\begin{tabular}{|c|c|c|c|c|c|c|}
\hline Age & Formation & Member & \begin{tabular}{|c} 
Faunal \\
Unit \\
\end{tabular} & \begin{tabular}{|c} 
Faunal \\
Unit \\
\end{tabular} & Formation & Age \\
\hline \multirow{4}{*}{ 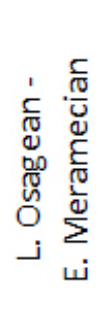 } & \multirow{11}{*}{$\begin{array}{l}\frac{\overrightarrow{0}}{\bar{N}} \\
\frac{0}{0} \\
\frac{\vec{v}}{J}\end{array}$} & \multirow{4}{*}{ Doña Ana } & \multirow{4}{*}{7} & \multirow{4}{*}{7} & Salem Ls & \multirow{2}{*}{ 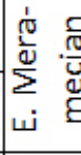 } \\
\hline & & & & & \begin{tabular}{|c} 
Upper Warsaw \\
Sh \\
\end{tabular} & \\
\hline & & & & & L. Warsaw & \multirow{9}{*}{ 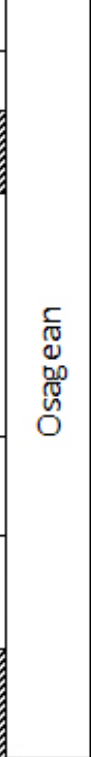 } \\
\hline & & & & & Keokuk Ls & \\
\hline \multirow{7}{*}{ 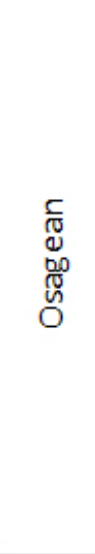 } & & Arcente & 6 & 5 & \multirow{4}{*}{$\begin{array}{l}\text { Burlington } \\
\text { Limestone }\end{array}$} & \\
\hline & & & & 40 & & \\
\hline & & Tierra & 5 & $4 \mathrm{~L}$ & & \\
\hline & & Blanca & 4 & \multirow[b]{2}{*}{ 3B } & & \\
\hline & & Nunn & \multirow[b]{2}{*}{3} & & $\begin{array}{c}\text { Fern Glen } \\
\text { Ls }\end{array}$ & \\
\hline & & $\begin{array}{l}\text { Alamo- } \\
\text { gordo }\end{array}$ & & $3 \mathrm{~A}$ & Meppen Ls & \\
\hline & & $\begin{array}{l}\text { Andre- } \\
\text { cito }\end{array}$ & 2 & 2 & & \\
\hline
\end{tabular}

FiguRE 1.2.-Comparative stratigraphic column showing how the Lake Valley Formation and the Burlington Limestone correlate to each other using conodont faunal units proposed by Lane (1974) for the Lake Valley and Lane and Brenckle (2001) for the Burlington. 


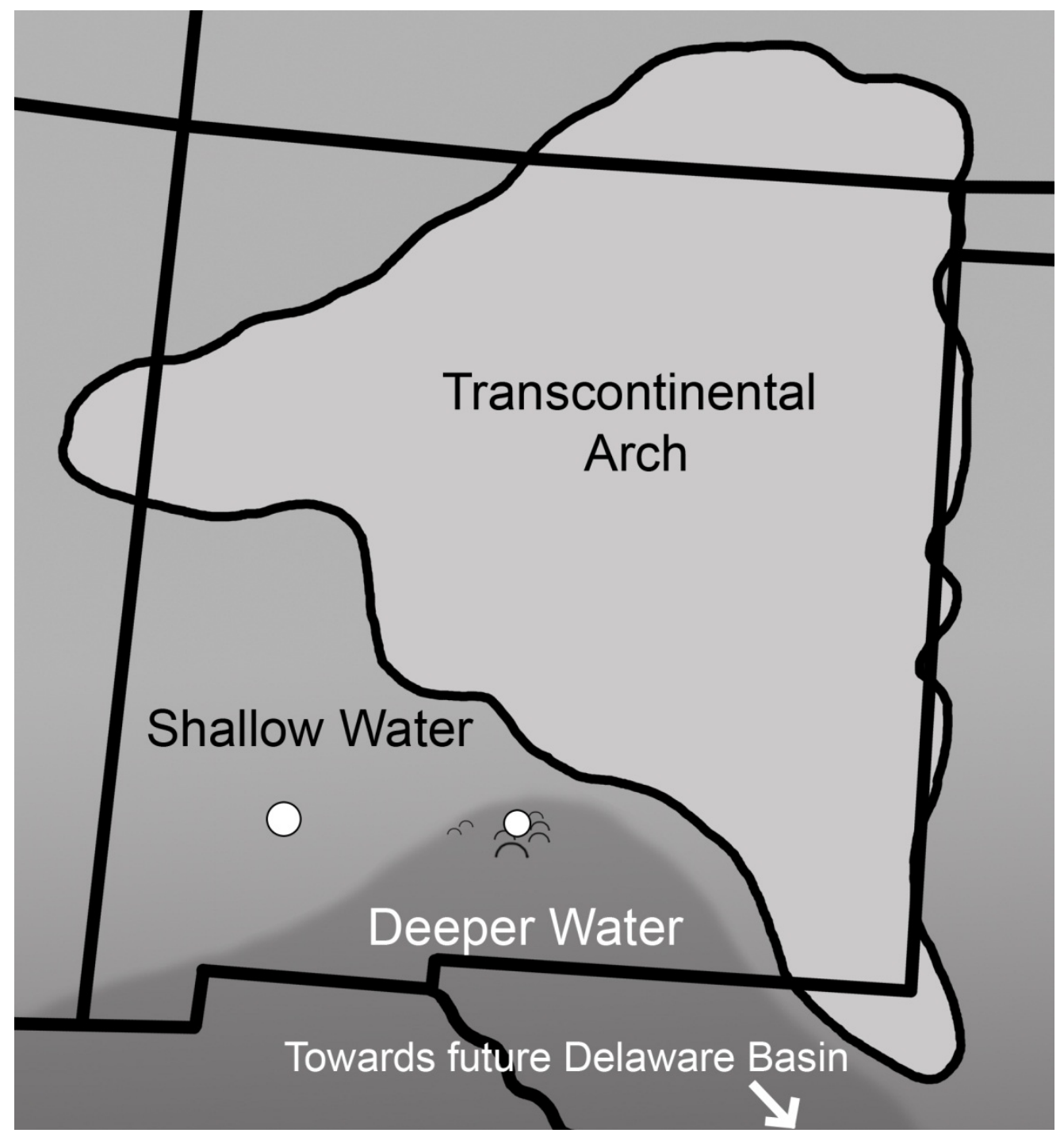

FIGURE 1.3.-Map showing the paleogeography of the area during the Early Osagean. The white markers indicate the main collecting localities (Sacramento Mountains to the east and Black Range to the west). The basin to the southeast of the Lake Valley Formation does not have a Mississippian name, but is where the Permian Delaware Basin forms. 


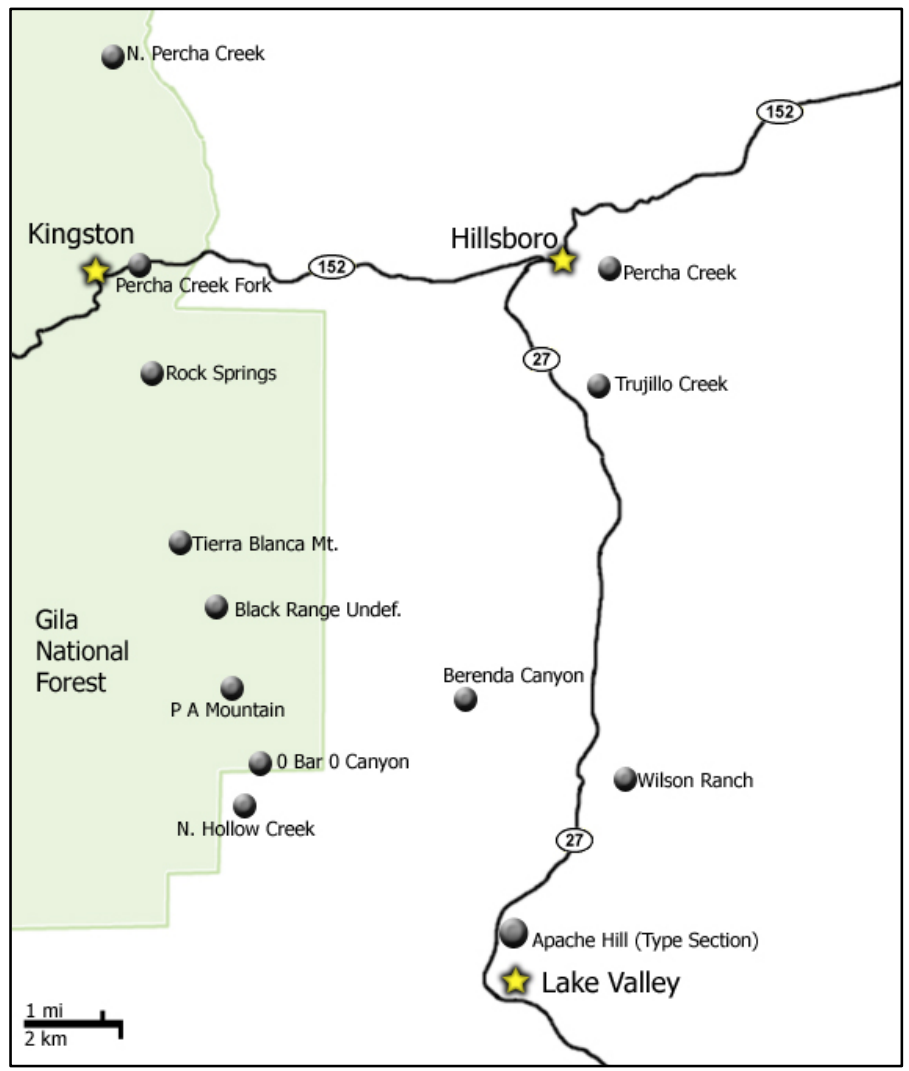

FIGURE 1.4.-Map showing the grouped localities in the Black Range (see Fig. 1). 


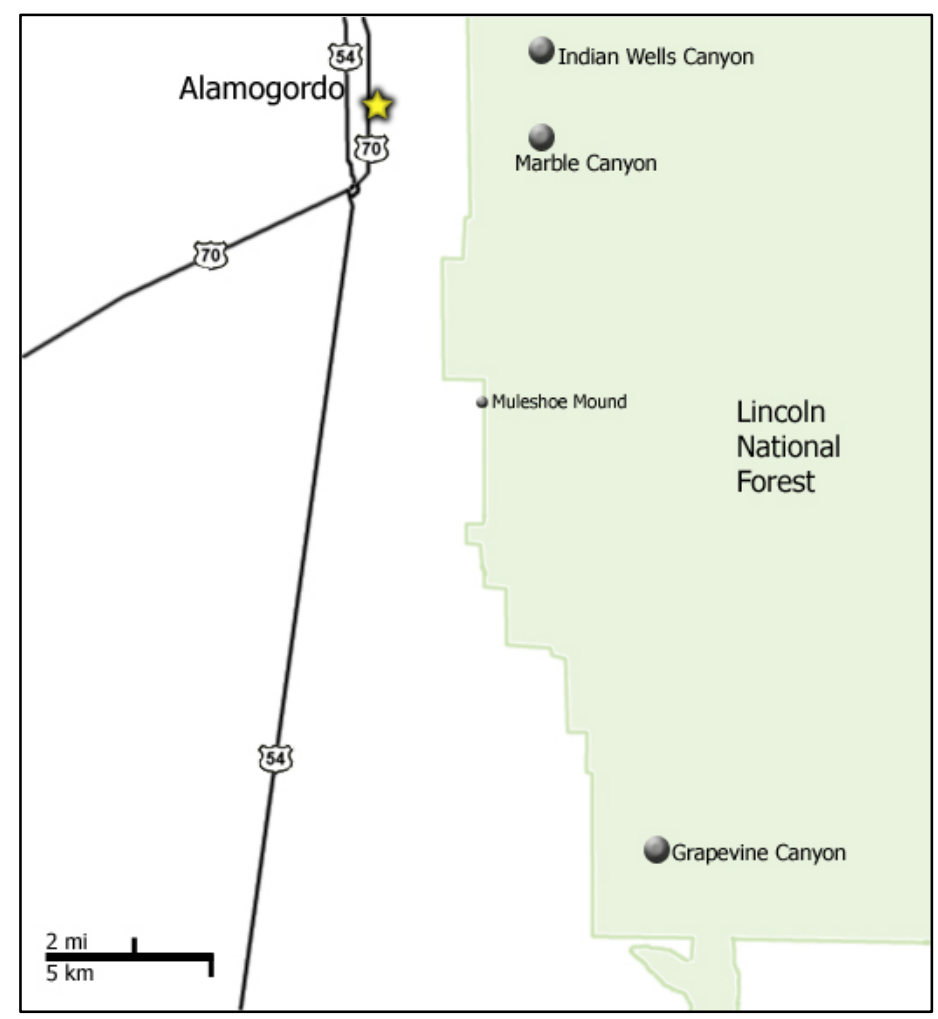

FIGURE 1.5.-Map showing the grouped localities in the Sacramento Mountains (see Fig. 1). 


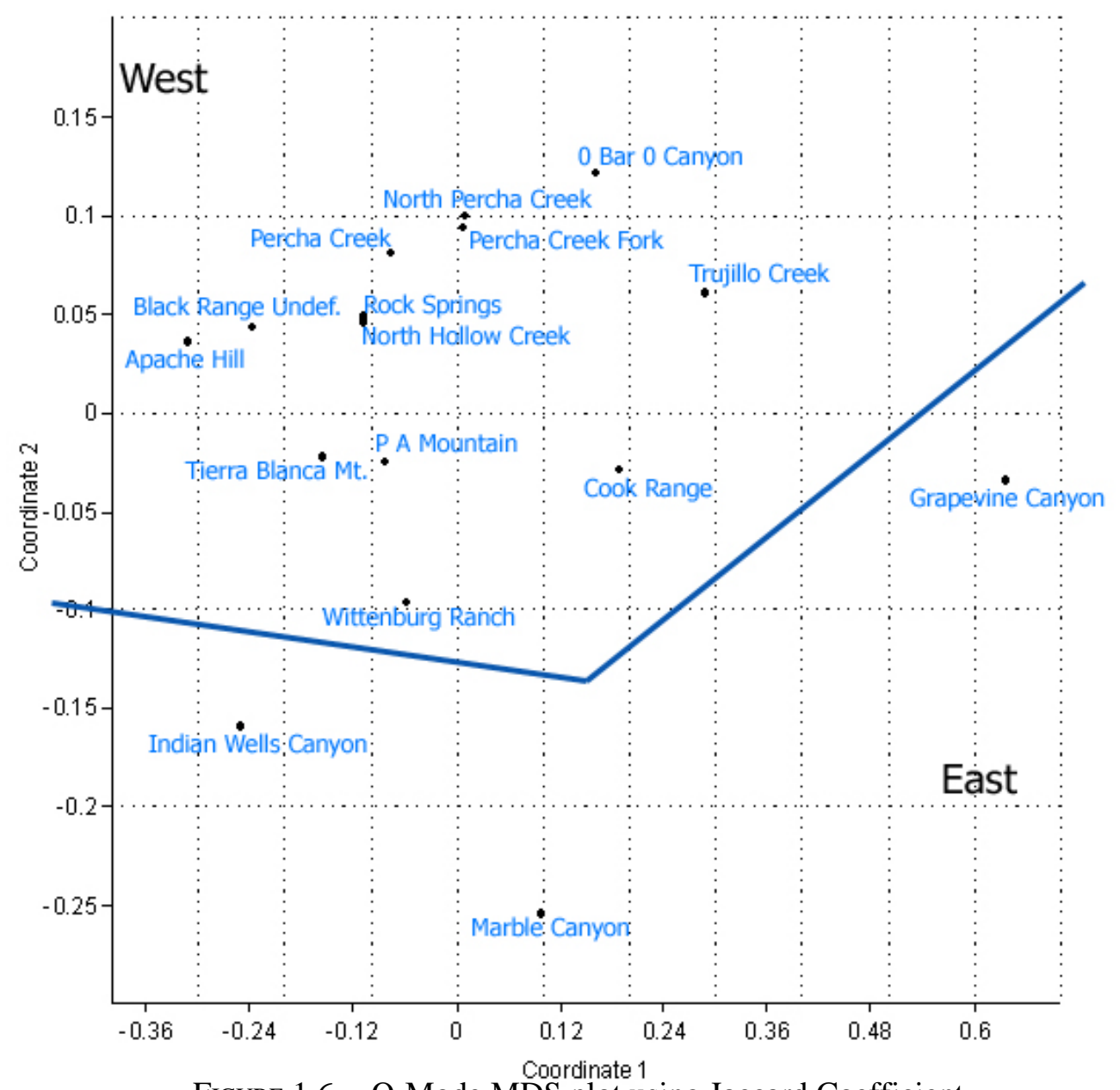

FIGURE 1.6.-Q-Mode MDS plot using Jaccard Coefficient showing the distribution of the 16 collecting localities (Berenda Canyon and Wilson Ranch excluded because they have one taxon each). A divide between the eastern localities and western localities is evident. Stress value $=0.13$, which is a fair to good fit (Kruskal, 1964). 

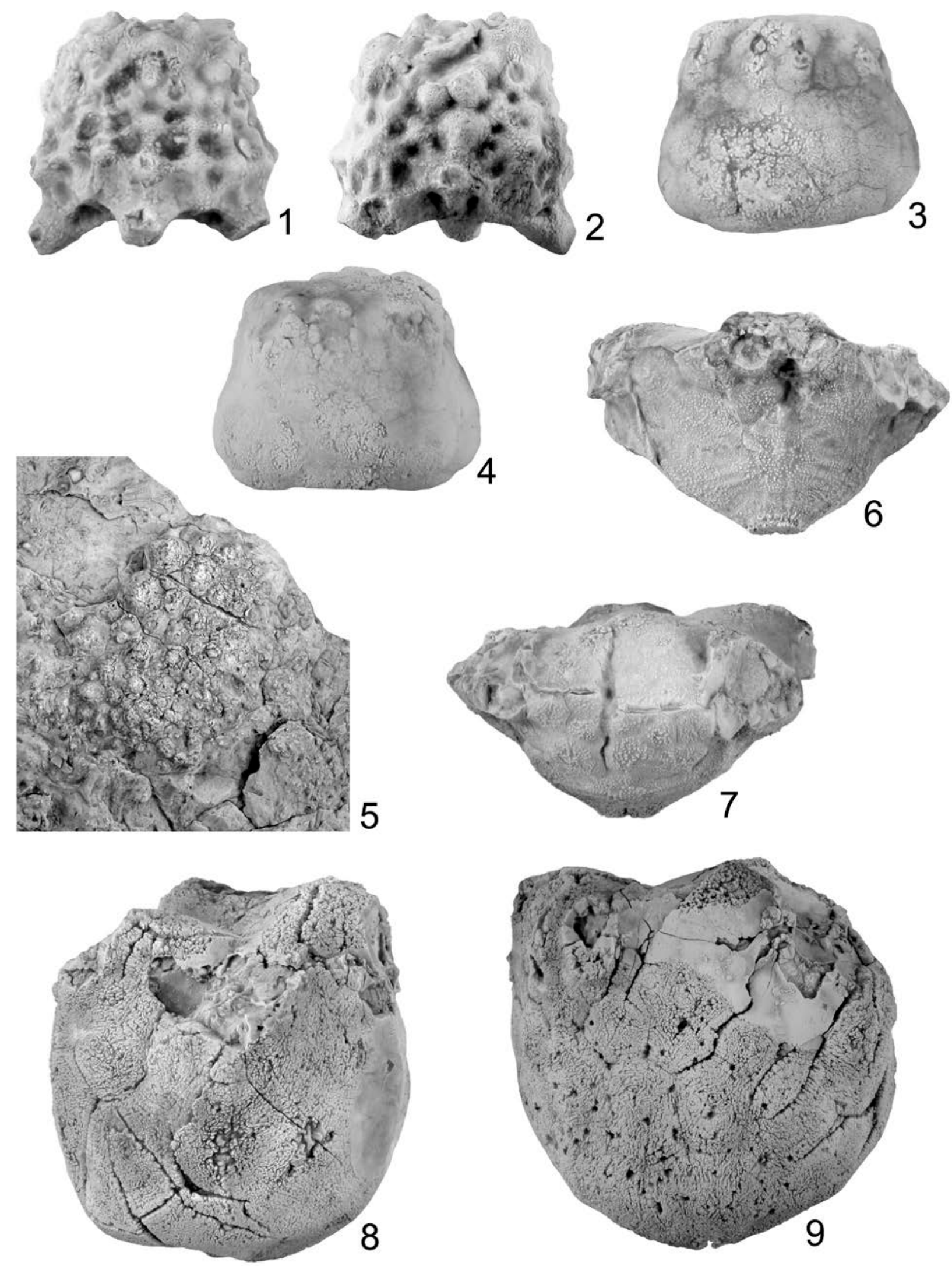
FIGURE 1.7.- Crinoids from the families Rhodocrinitidae (diplobathrid) and Periechocrinidae (monobathrid). 1,2, Rhodocrinites tuberculatus (Wachsmuth and Spinter 1897), x3.0: 1, A-ray lateral view; 2, CD interray lateral view. 3,4, Cribanocrinus urceolatus (Wachsmuth and Springer, 1897), x3.0: 3, A-ray lateral view; 4, CD interray lateral view. 5, Gilbertsocrinus sp., tegmen view, x1.5. 6,7, Aryballocrinus tenuidiscus (Hall, 1861), x2.0: 6, A-ray lateral view; 7, CD interray lateral view. 8,9, Aryballocrinus whitei (Hall, 1861), x1.5: 8, A-ray lateral view; 9, CD interray lateral view. 

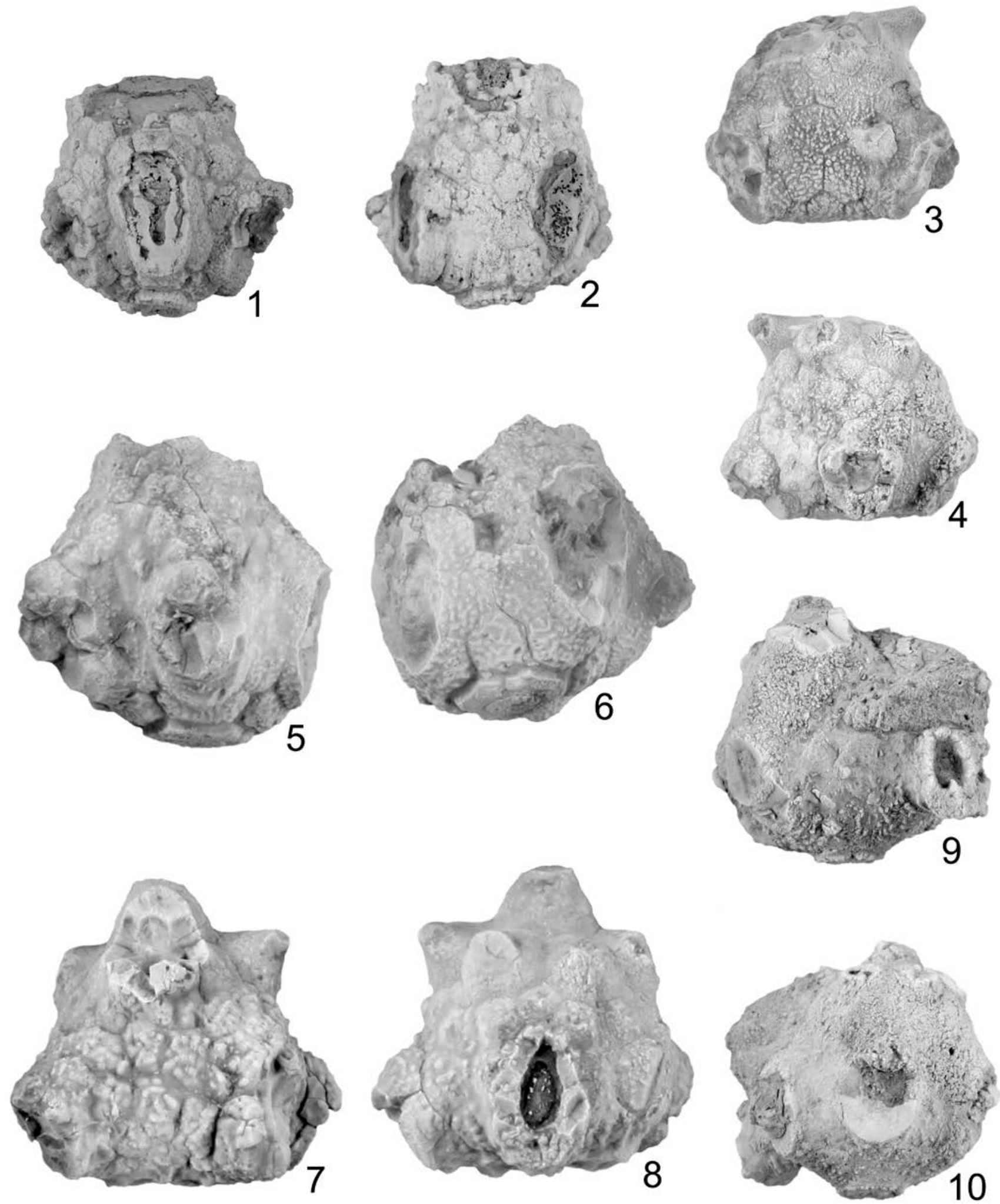
FIGURE 1.8.-Crinoids from the family Amphoracrinidae. 1,2, Amphoracrinus rupinus Webster and Lane, 1987, x1.5: 1, A-ray lateral view; 2, CD interray lateral view. 3,4, Ancalocrinus spinobrachiatus (Hall, 1859), x2.0: 3, A-ray lateral view; 4, CD interray lateral view. 5,6, Ancalocrinus sp, x3.0: 5, A-ray lateral view; 6, CD interray lateral view. 7,8 Displodocrinus divergens (Hall, 1859), x3.0; 7, CD interray lateral view; 8, A-ray lateral view. 9, 10, Displodocrinus nevadensis (Webster and Lane, 1987), x2.0; 9, CD interray lateral view; 10, A-ray lateral view. 

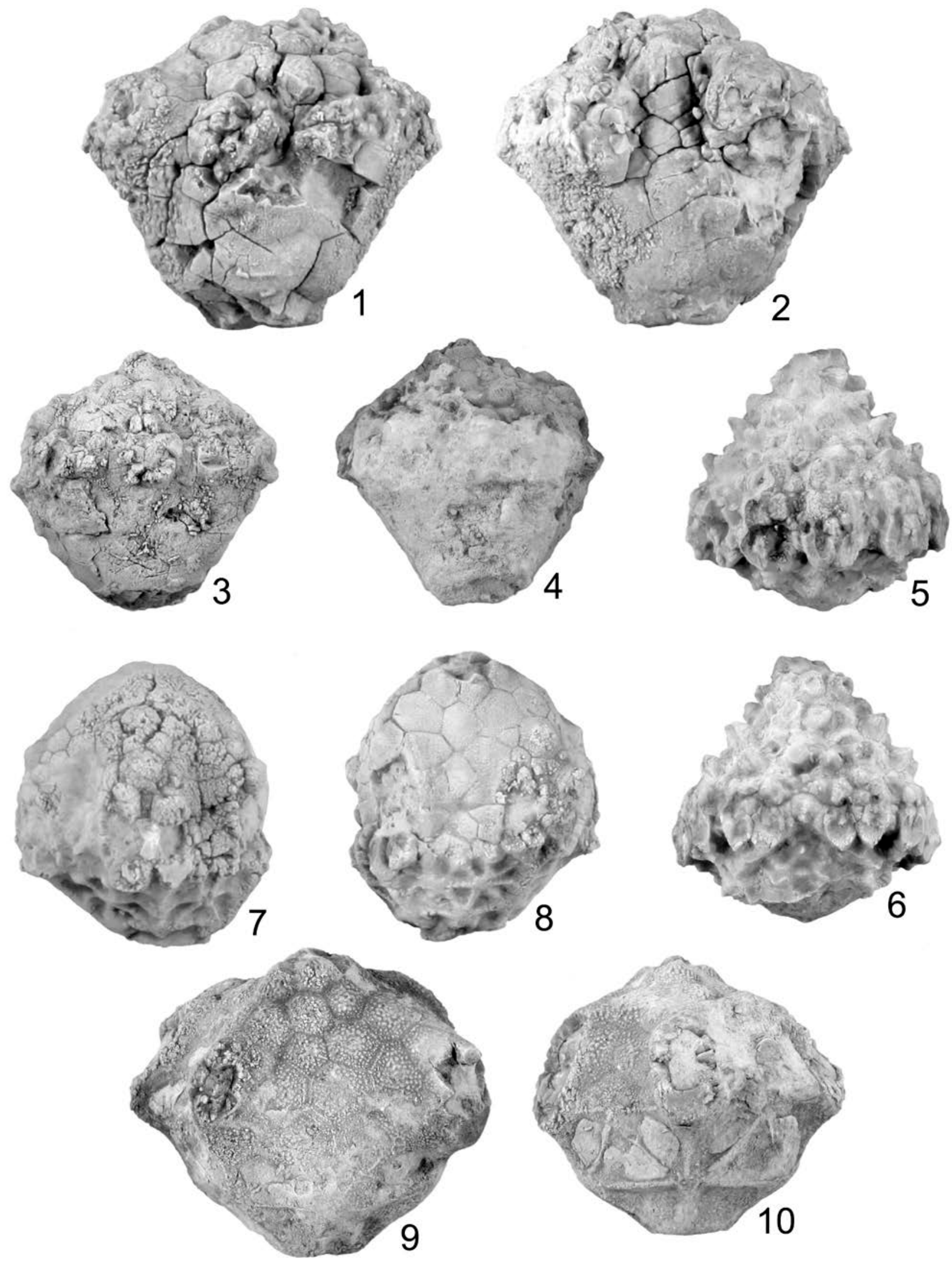
FiguRE 1.9.-Crinoids from the family Actinocrinitidae, subfamily Actinocrinitinae. 1,2, Aacocrinus nododorsatus Bowsher, 1955, x3.0: 1, A-ray lateral view; 2, CD interray lateral view. 3,4, Aacocrinus enigmaticus Webster and Lane, 1987, x2.0: 3, A-ray lateral view; 4, CD interray lateral view. 5,6, Blairocrinus macurdai n. sp; UMMP 74066; x2.0: 5, A-ray lateral view; 6, CD interray lateral view. 7,8 Iotacrinus novamexicana n. sp.; UMMP 74068; x3.0; 7,A-ray lateral view; 8, CD interray lateral view. 9, 10, Steganocrinus pentagonus (Hall, 1858), x2.0; 9, CD interray lateral view; 10, A-ray lateral view. 


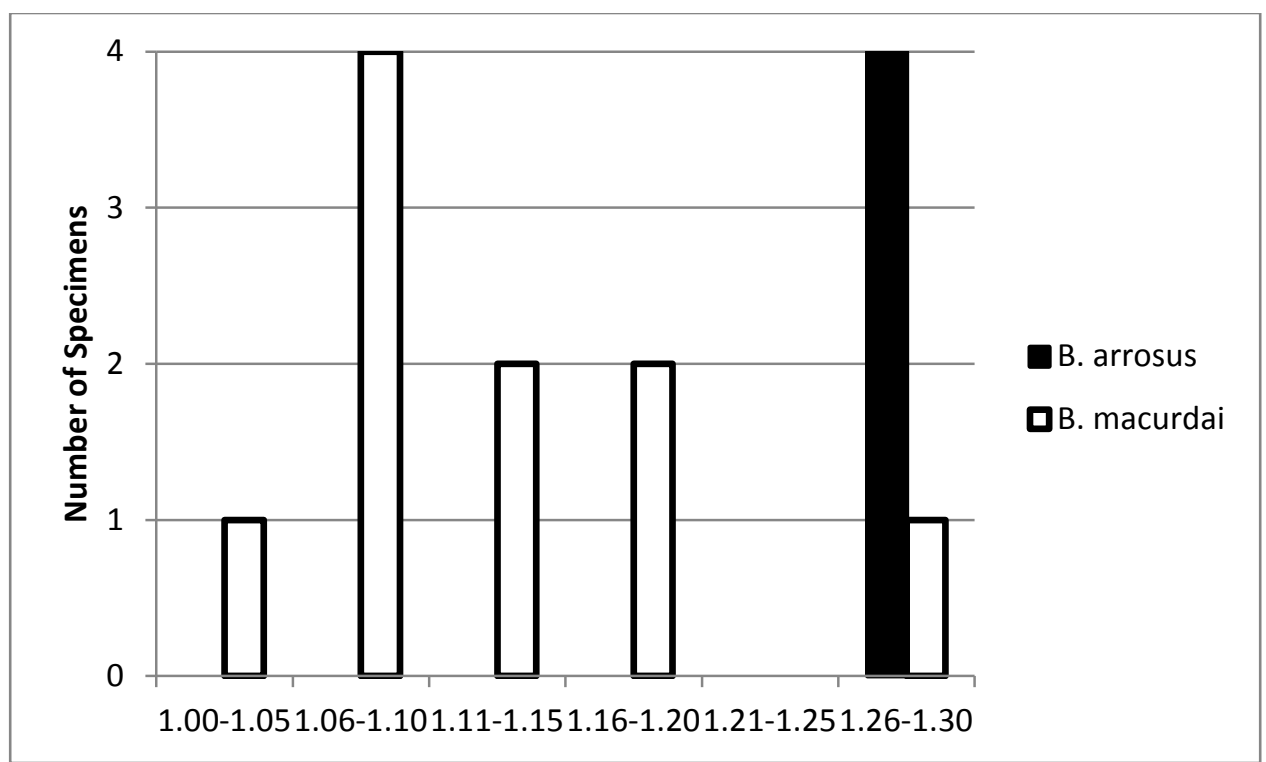

FIGURE 1.10.-Chart showing the ratio differences between the protuberance of arm rays between Blairocrinus arrosus and B. macurdai n. sp. 

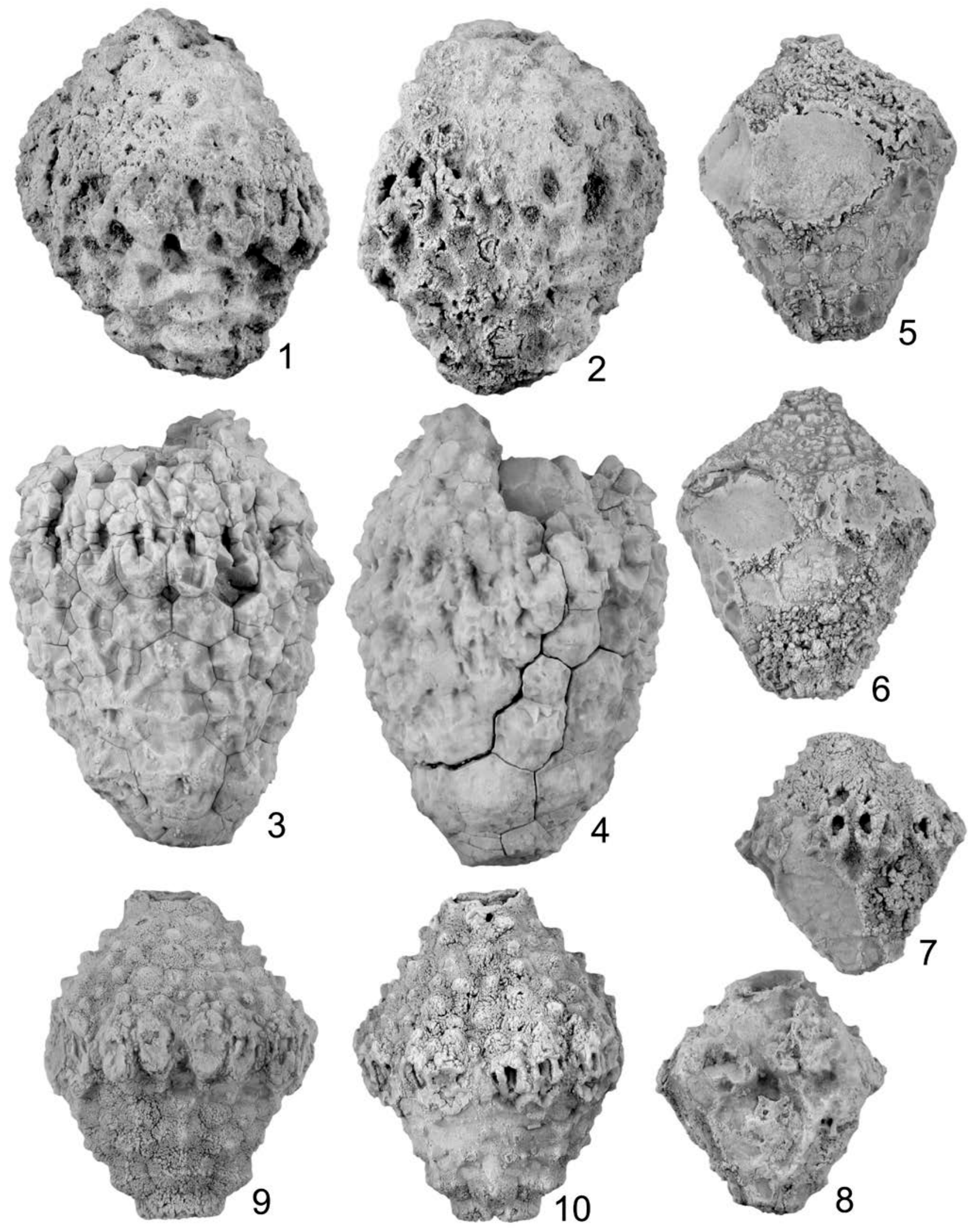
FIGURE 1.11.-Crinoids from the family Actinocrinitidae, subfamily Cactocriniae. 1,2, Cactocrinus proboscidalis (Hall, 1858), x2.0: 1, A-ray lateral view; 2, CD interray lateral view. 3,4, Cactocrinus multibrachiatus (Hall, 1858), x1.5: 3, A-ray lateral view; 4, CD interray lateral view. 5,6, Cusacrinus sobrinus (Miller and Gurley, 1896), x2.0: 5, A-ray lateral view; 6, CD interray lateral view. 7,8 Cusacrinus tenuisculptus (McChesney, 1861), x2.0; 7,A-ray lateral view; 8, CD interray lateral view. 9, 10, Nunnacrinus dalyanus (Miller, 1881), x1.5; 9, A-ray lateral view; 10, CD interray lateral view. 

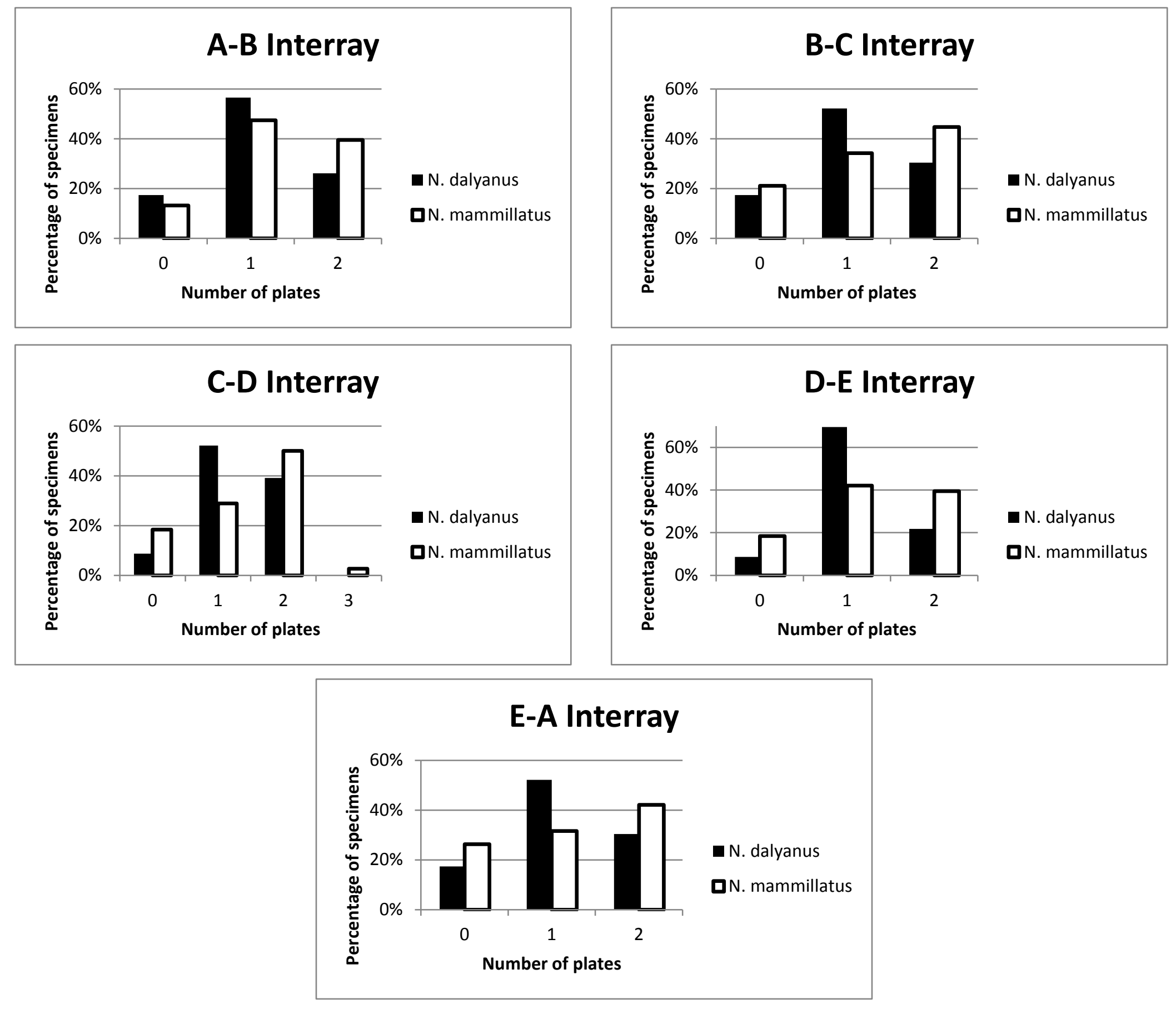
FIGURE 1.12.- Plots showing the interradial plate number that separates the rays on the 61 Nunnacrinus specimens ( $N$. dalyanus $\mathrm{n}=23$; $N$. mammillatus $\mathrm{n}=38$ ) found in the Springer Room of the Smithsonian. Brower (1955) states that $N$. dalyanus only has one interradial plate between rays and $N$. mammillatus has two. Examination of the interradial plates shows that there is no set pattern and that most specimens have both single and double plates between rays and therefore making N. mammillatus a junior synonym of $N$. dalyanus. Zero plates in the interray indicate that those interrays were poorly preserved and the number of plates could not be counted. Specific information on the specimens from the Smithsonian can be found in Appendix 3. 

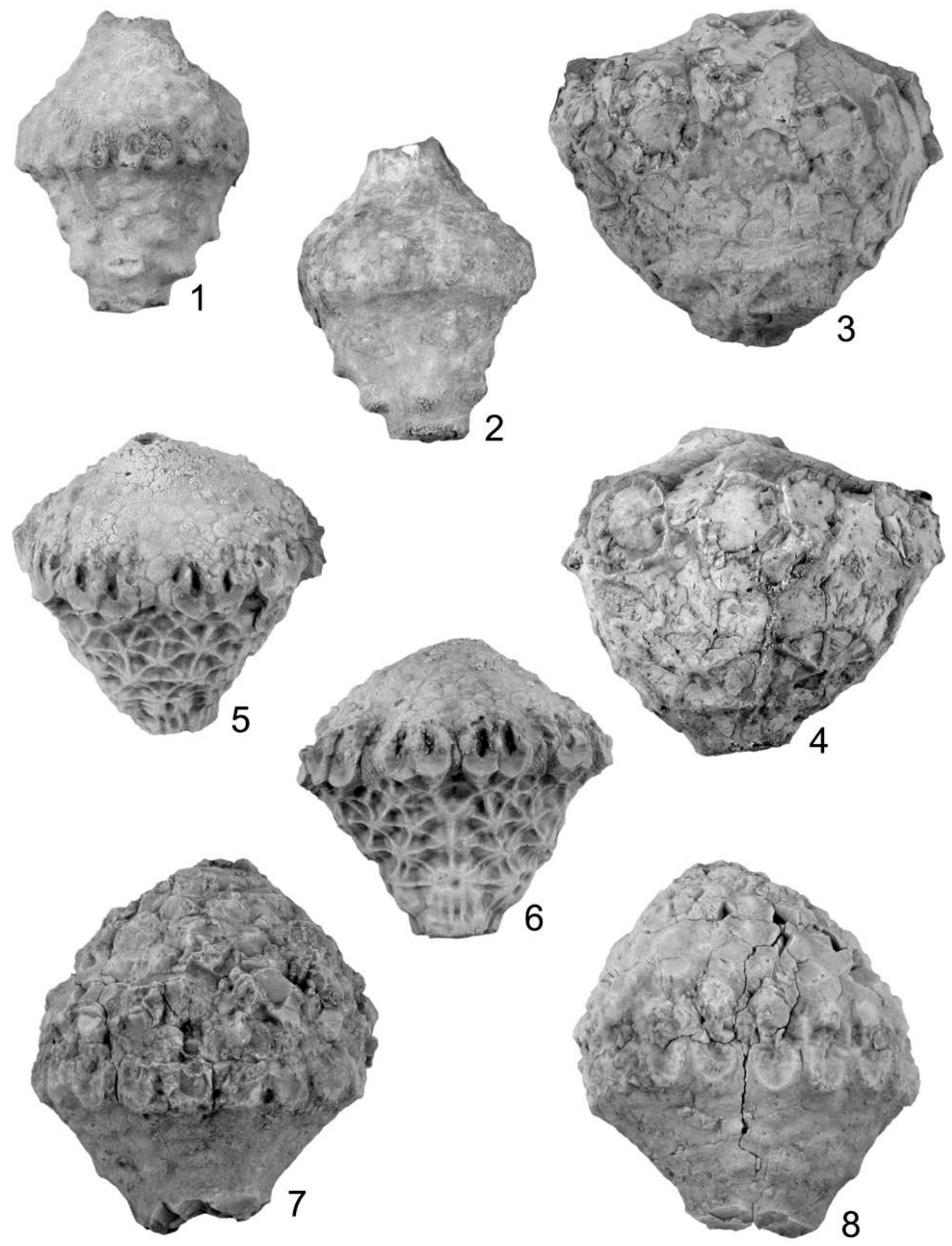
FIGURE 1.13.-Crinoids from the family Actinocrinitidae, subfamily Cactocriniae, subfamily Physetocrininae and family Batocrinidae. 1,2, Teleiocrinus umbrosus (Hall, 1858), x1.5: 1, A-ray lateral view; 2, CD interray lateral view. 3,4, Physetocrinus lobatus Wachsmuth and Springer, 1897, x2.0: 3, CD interray lateral view; 4, A-ray lateral view. 5,6, Physetocrinus copei (Miller, 1881), x1.5: 5, CD interray lateral view; 6, A-ray lateral view. 7,8 Abatocrinus aequalis (Hall, 1858), x2.0; 7,A-ray lateral view; 8, CD interray lateral view. 


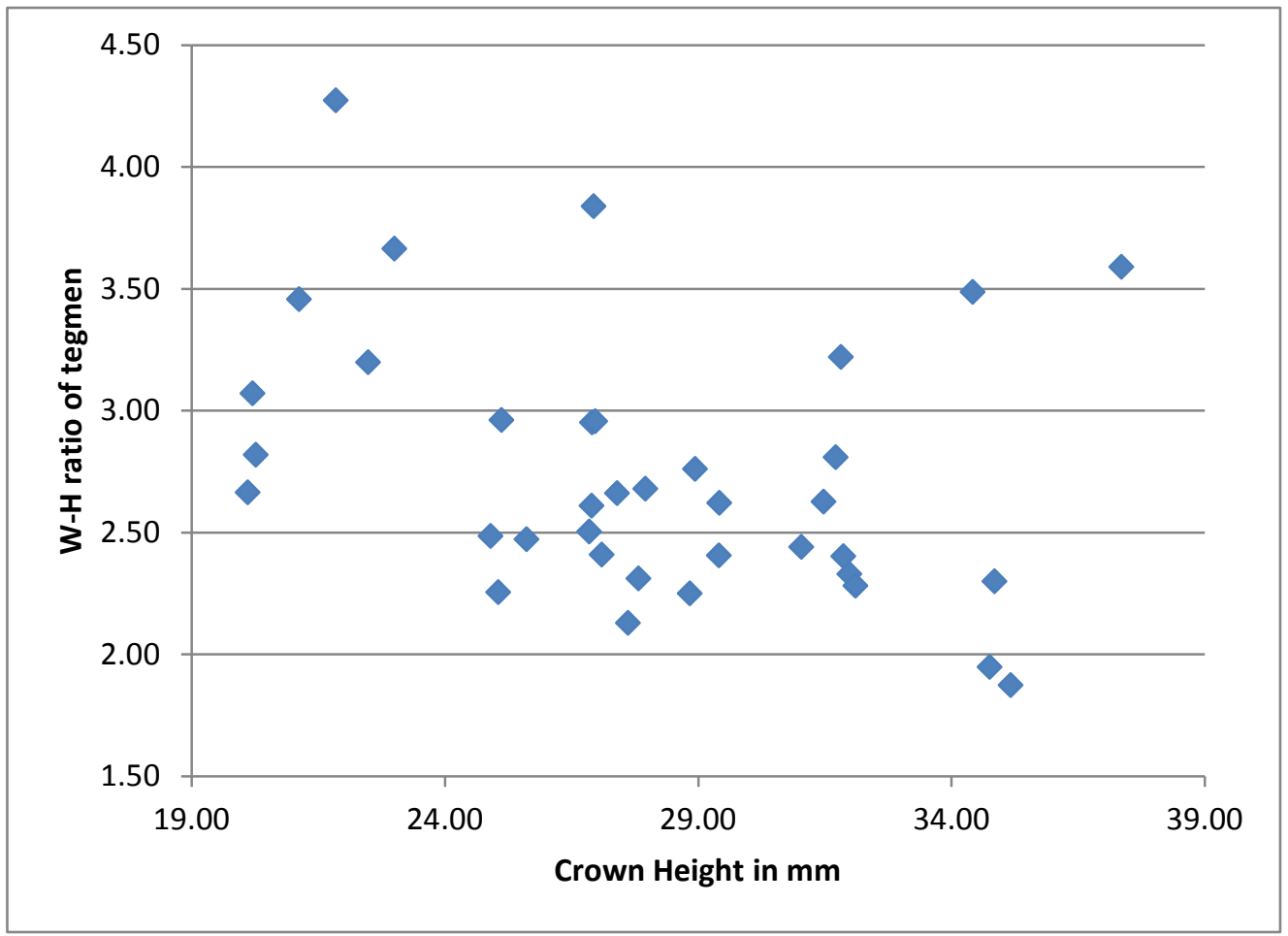

FIGURE 1.14.-Width-height ratio of the tegmens of 37 specimens of Physetocrinus copei from the undefined Black Range area (locality M-17) showing the variation of tegmen inflation as compared to the height of the crown. 


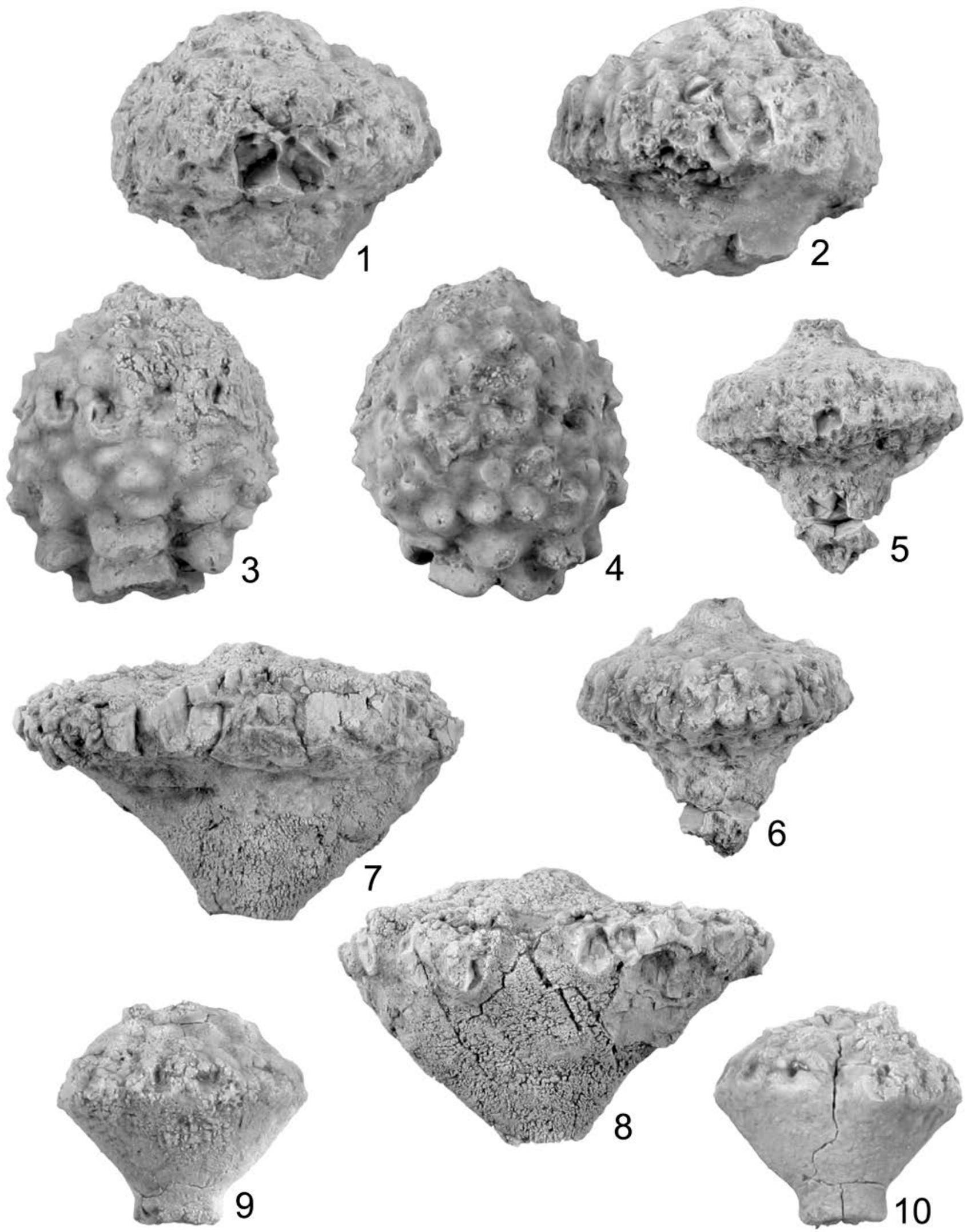


FIGURE 1.15.-Crinoids from the family Batocrinidae. 1,2, Abatocrinus clypeatus (Hall, 1859), x3.0: 1, A-ray lateral view; 2, CD interray lateral view. 3,4, Eretmocrinus corbulis (Hall, 1861), x3.0: 3, A-ray lateral view; 4, CD interray lateral view. 5,6, Eutrochocrinus christyi (Shumard, 1855), x2.0: 5, CD interray lateral view; 6, A-ray lateral view. 7,8 Eutrochocrinus lovei (Wachsmuth and Springer, 1881), x2.0; 7,A-ray lateral view; 8, CD interray lateral view. 9, 10, Simatocrinus sp., x3.0; 9, A-ray lateral view; 10, CD interray lateral view. 

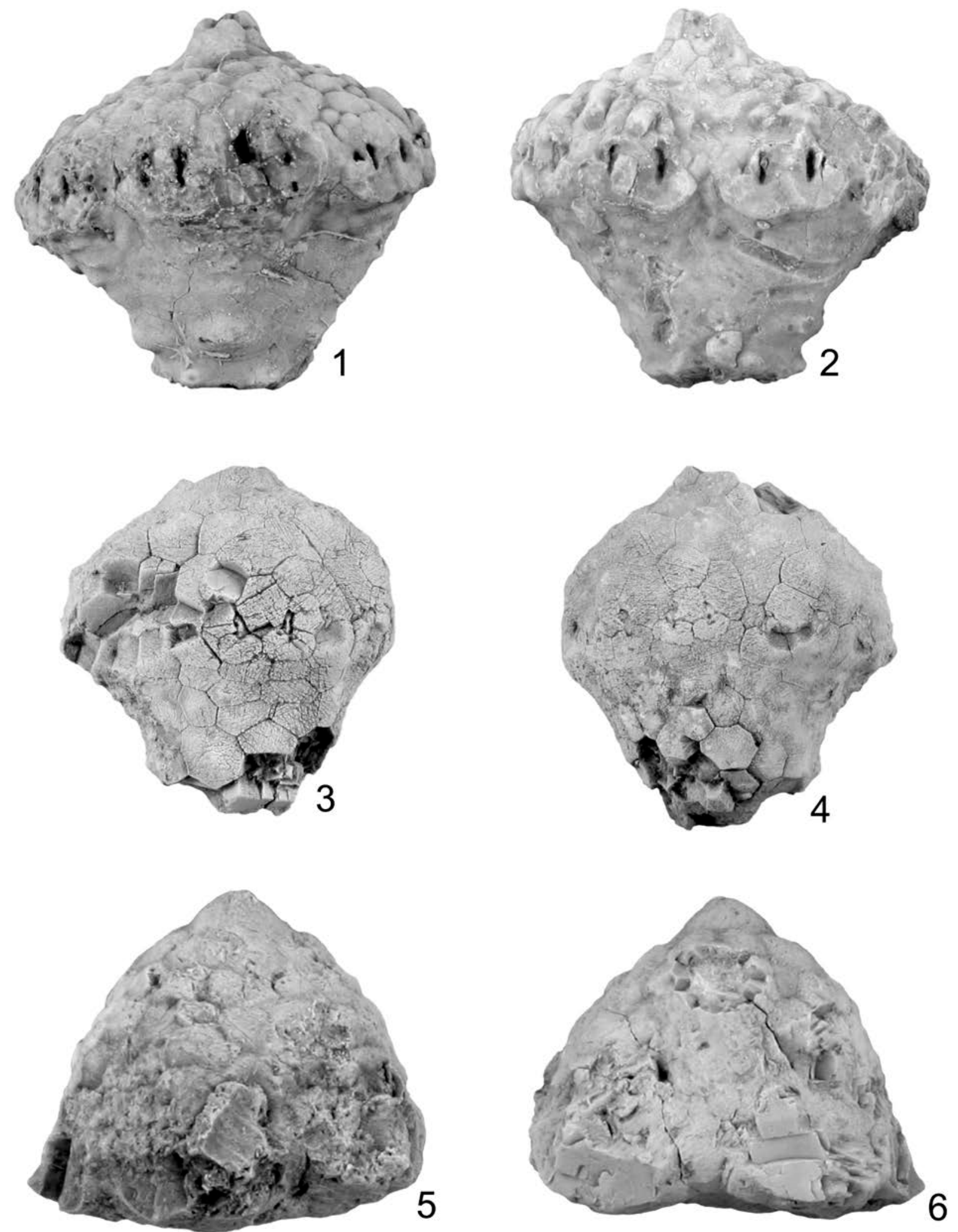
FIGURE 1.16.-Crinoids from the families Batocrinidae and Coelocrinidae. 1,2, Uperocrinus kuesi n. sp.; UMMP 74071; x2.0: 1, A-ray lateral view; 2, CD interray lateral view. 3,4, Uperocrinus sp., x2.0: 3, A-ray lateral view; 4, CD interray lateral view. 5,6, Agaricocrinus bullatus Hall, 1858, x3.0: 5, A-ray lateral view; 6, CD interray lateral view. 

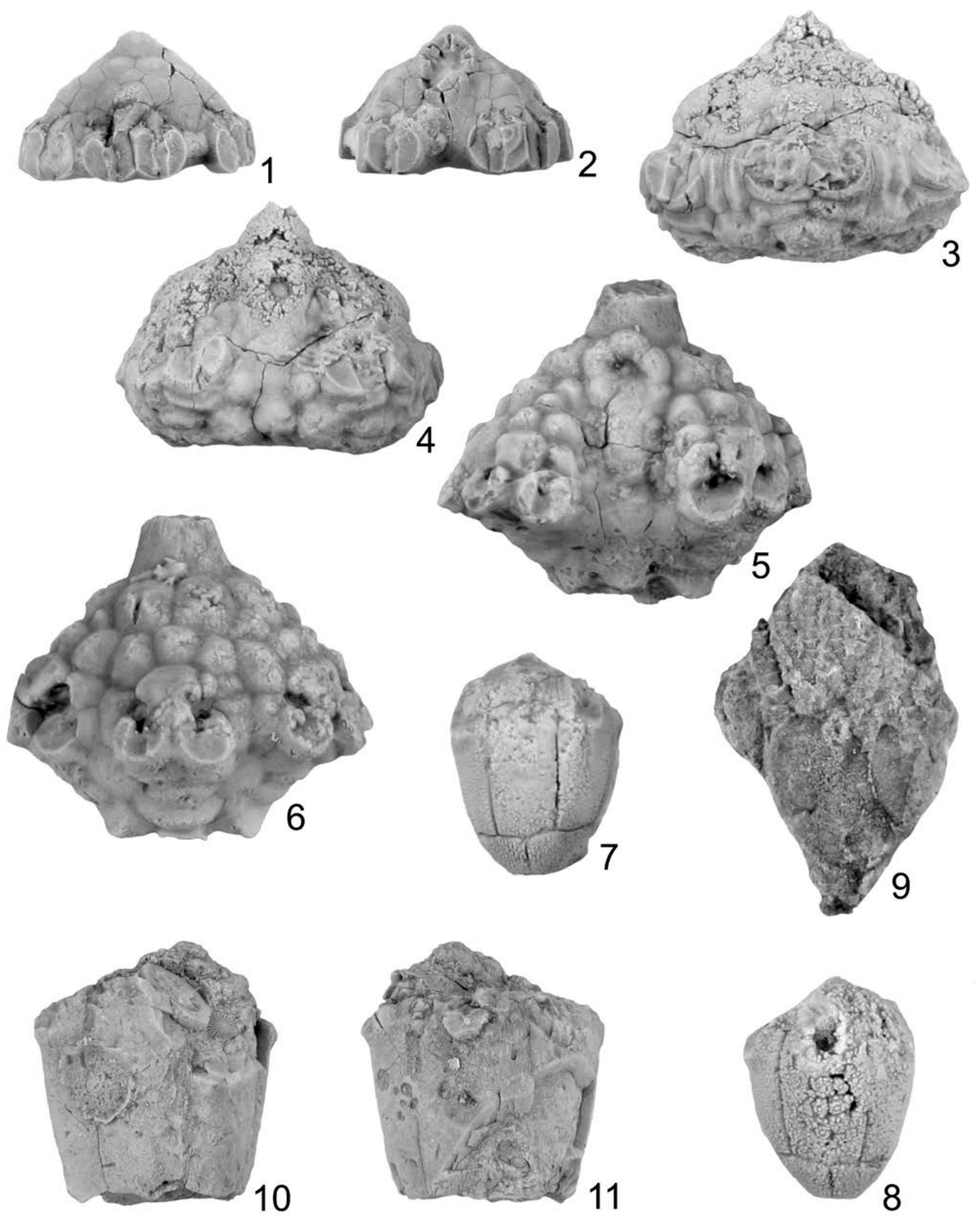
FIGURE 1.17.-Crinoids from the families Coelocrinidae and Dichocrinidae. 1,2, Agaricocrinus planoconvexus Hall, 1861, x3.0: 1, A-ray lateral view; 2, CD interray lateral view. 3,4, Agaricocrinus pyramidatus (Hall, 1858), x3.0: 3, A-ray lateral view; 4, CD interray lateral view. 5,6, Agaricocrinus alamogordoensis n. sp.; UMMP 74072; x3.0: 5, CD interray lateral view; 6, A-ray lateral view. 7-9, Dichocrinus conus Meek and Worthen, 1860, x3.0; 7,CD interray lateral view; 8, A-ray lateral view; 9, different specimen that shows the arms attached. 10,11, Dichocrinus sp., x2.0; 10, CD interray lateral view; 11, A-ray lateral view. 

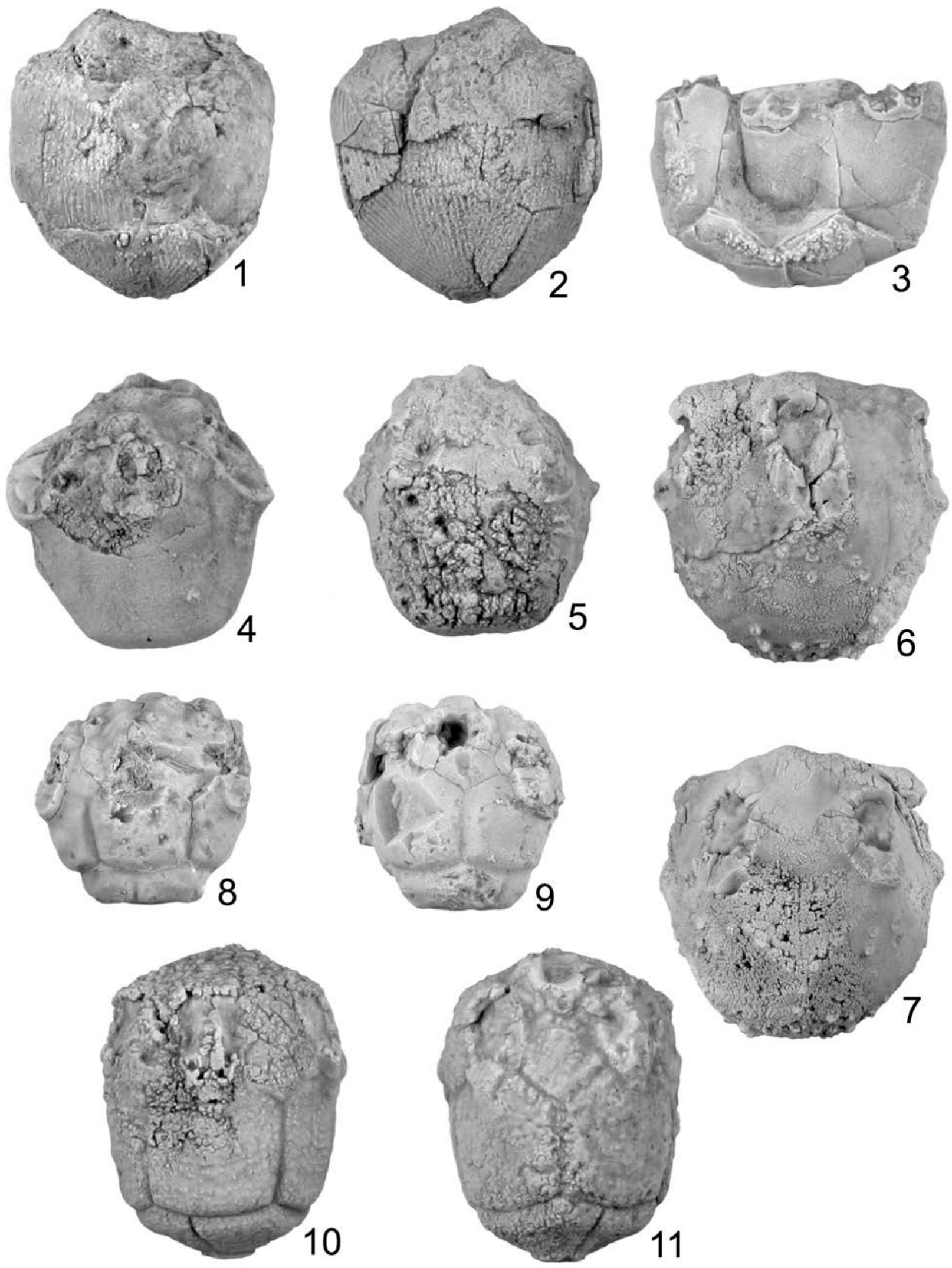
FIGURE 1.18.-Crinoids from the families Dichocrinidae and Platycrinitidae. 1,2, Srimplecrinus pisum (Meek and Worthen, 1869), x3.0: 1, A-ray lateral view; 2, CD interray lateral view. 3, Strimplecrinus sp., x3.0. 4,5, Platycrinites burlingtonensis (Owen and Shumard, 1850), x3.0: 4, A-ray lateral view; 5, CD interray lateral view. 6,7, Platycrinites parvinodus (Hall, 1861), x2.0; 6, A-ray lateral view, 7,CD interray lateral view. 8,9, Platycrinites illiniosensis (Miller and Gurley, 1896), x2.0: 8, A-ray lateral view; 9, CD interray lateral view. 10,11, Platycrinites peculiaris (Wachsmuth and Springer, 1897), x3.0; 10, A-ray lateral view; 11, CD interray lateral view. 

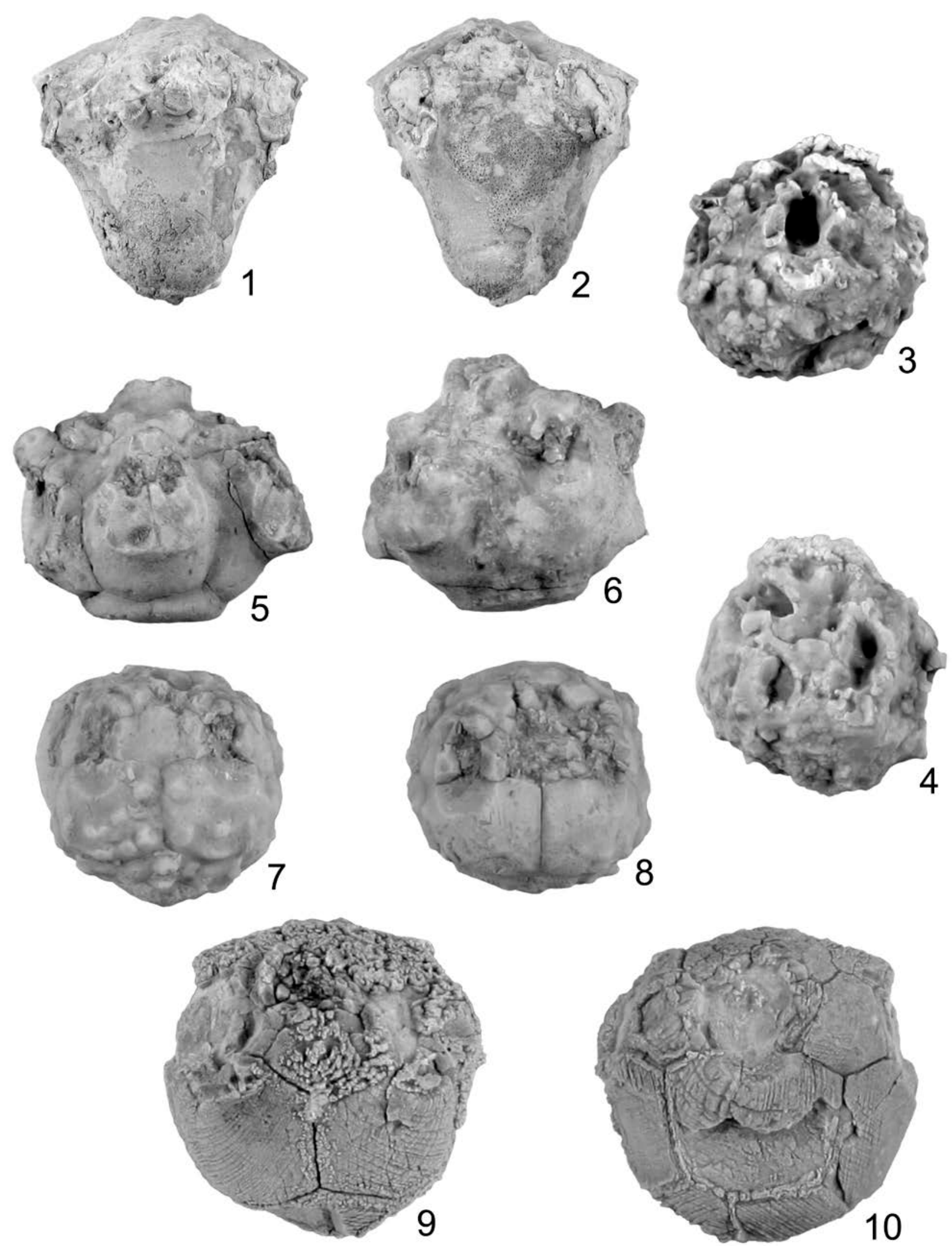

8

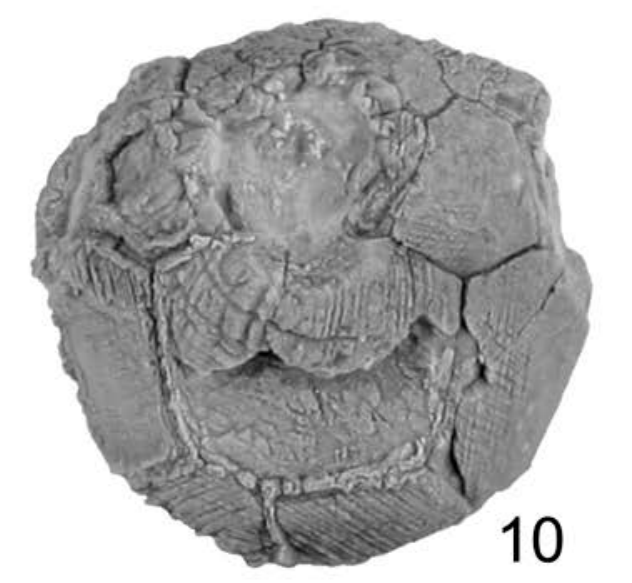


FIGURE 1.19.-Crinoids from the family Platycrinitidae. 1,2, Platycrinites sp., x1.5: 1, A-ray lateral view; 2, CD interray lateral view. 3,4, Collicrinus shumardi Ausich and Kammer, 2009, x3.0: 3, A-ray lateral view; 4, CD interray lateral view. 5,6, Collicrinus laudoni n. sp.; UMMP 74073; x3.0: 5, Aray lateral view; 6, CD interray lateral view. 7,8 Elegantocrinus canaliculatus (Hall, 1858), x3.0; 7, CD interray lateral view; 8, A-ray lateral view. 9, 10, Elegantocrinus annosus (Miller, 1891), x3.0; 9, CD interray lateral view; 10, A-ray lateral view. 

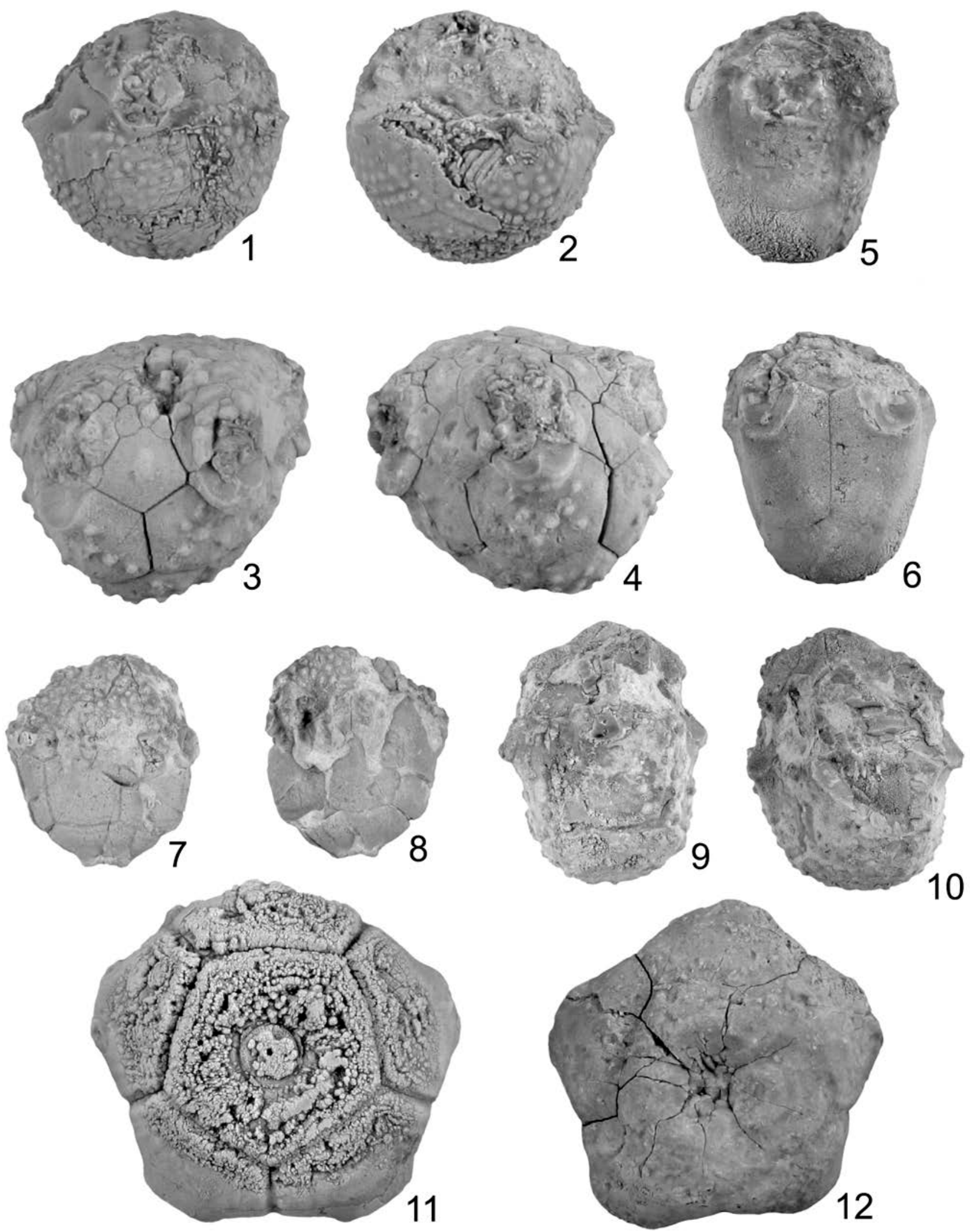
FIGURE 1.20.-Crinoids from the family Platycrinitidae. 1,2, Elegantocrinus nodostriatus (Wachsmuth and Spinger, 1897), x3.0: 1, A-ray lateral view; 2, CD interray lateral view. 3,4, Elegantocrinus pocilliformis (Hall, 1858), x3.0: 3, CD interray lateral view; 4, A-ray lateral view. 5,6, Elegantocrinus pileiformis (Hall, 1858), x2.0: 5, A-ray lateral view; 6, CD interray lateral view. 7,8 Elegantocrinus sp. A, x2.0; 7, A-ray lateral view; 8, CD interray lateral view. 9, 10, Elegantocrinus sp. B, x1.5; 9, A-ray lateral view; 10, CD interray lateral view. 11, Eucladocrinus pleuroviminus (White, 1862), aboral view, x2.0. 12, Eucladocrinus sp., aboral view, x2.0. 

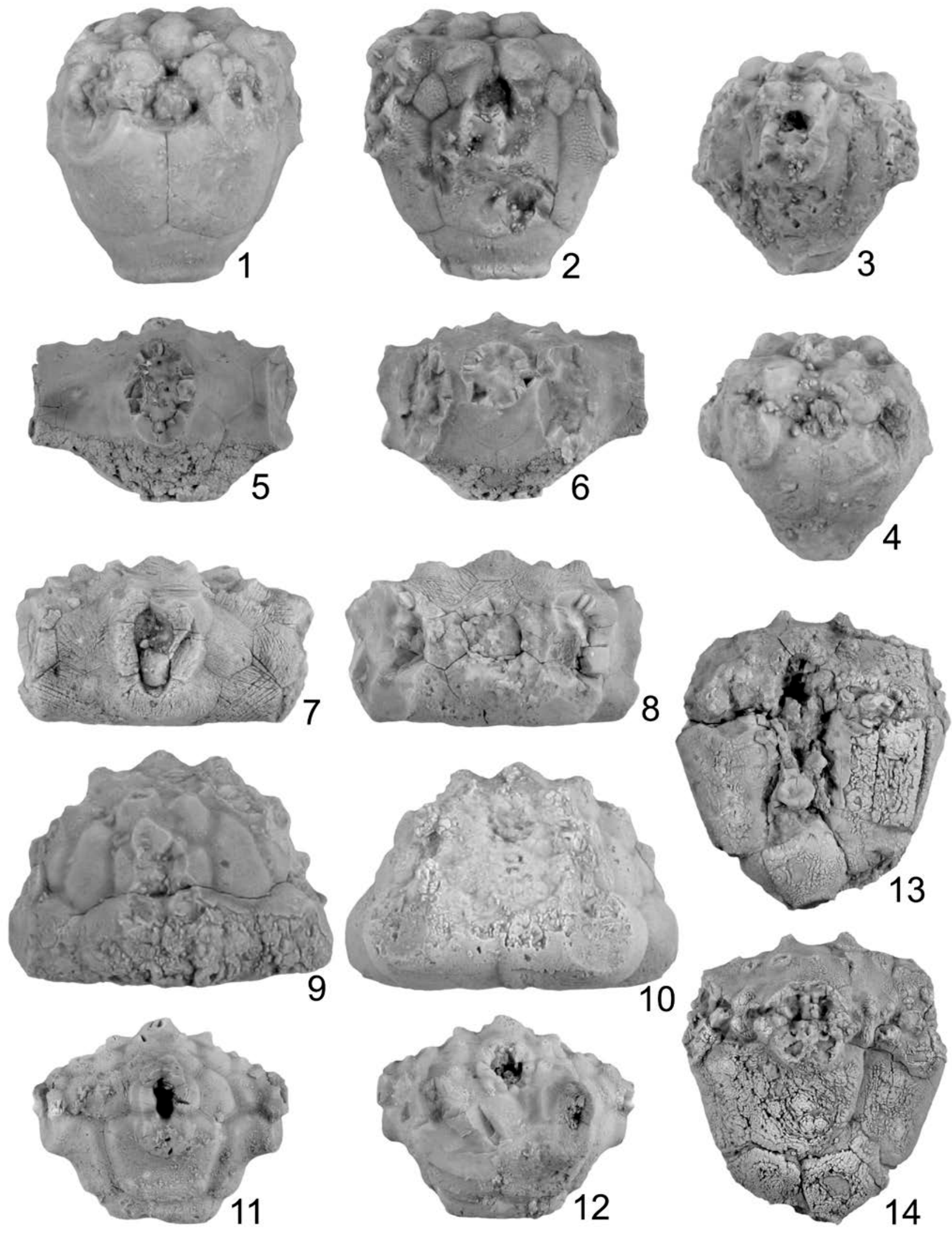
FIgURE 1.21.-Crinoids from the family Platycrinitidae. 1,2, Oenochoacrinus limbus Webster and Lane, 1987, x3.0: 1, CD interray lateral view; 2, A-ray lateral view. 3,4, Oenochoacrinus cortina (Miller and Gurley, 1894), x3.0: 3, A-ray lateral view; 4, CD interray lateral view. 5,6, Plemnocrinus bullatus Kirk, 1946, x2.0: 5, A-ray lateral view; 6, CD interray lateral view. 7,8 Plemnocrinus homalus Kirk, 1946, x2.0; 7, A-ray lateral view; 8, CD interray lateral view. 9, 10, Plemnocrinus subpinosus (Hall, 1858), x3.0; 9, A-ray lateral view; 10, CD interray lateral view. 11,12, Pleurocrinus quiquenodus (White, 1862), x2.0: 11, A-ray lateral view; 12, CD interray lateral view. 13,14 Pleurocrinus sp., x1.5: 13, CD interray lateral view; 14, A-ray lateral view. 
Chapter 2:

Generic Concepts in the Actinocrinitidae Austin and Austin, 1842 and Evaluation of Generic Assignments of North American Species

Elizabeth C. Rhenberg, William I. Ausich, and Thomas W. Kammer

\begin{abstract}
The Actinocrinitidae was a significant contributor to the global biodiversity peak of crinoids that occurred during the Mississippian and is referred to as the "Age of Crinoids.” Although the actinocrinitids are a major component of the high diversity, they are also a source of much taxonomic confusion. Generic concepts were not applied equally between Europe and North America creating disparity in genus definition. In this contribution, the global genera are defined objectively by discrete characters, and the generic assignments of the North American species are reevaluated. A phylogenetic hypothesis is presented for the relationships of the Actinocrinitidae genera based on a parsimony-based analysis and plotted against stratigraphic ranges. Although groupings were revealed in this analysis, the Actinocrinitidae cannot be readily divided into subfamilies. Twenty-one genera are described, 17 of which are found in North America. A total of 125 species were evaluated of which 34 species and one opennomenclature taxon are reassigned to different genera, and four species are designated as nomina dubia.
\end{abstract}

\title{
INTRODUCTION
}

The Actinocrinitidae is a very important family of Mississippian crinoids due to their considerable diversity and high abundance. Actinocrinitids encompass a large array of morphological disparity produced by the complex arrangements of their numerously plated 
calyxes. Because there are innumerable specimens in many Mississippian faunas and because we suspect that hybridization was a complicating factor as demonstrated in Eretmocrinus (Ausich and Meyer, 1994) and suggested for the Batocrinidae (Ausich and Kammer, 2010), this is a complex group. Both Wachsmuth and Springer (1897) and Bowsher (1955) worked to clarify generic definitions among North American actinocrinitids, but many issues still remain. First and most significant among these problems is that the generic concept for Actinocrinites, as defined by Actinocrinites triacontadactylus Miller, 1821, was not applied consistently to North American faunas.

Ausich and Sevastopulo (2001) designated a neotype for Actinocrinites triacontadactylus; and with this definition re-established, Ausich and Sevastopulo (2001) and Ausich and Kammer (2006) made generic reassignments to all actinocrinitids from Ireland, England, and Wales. Species-level systematics has only been completed for Ivorian faunas (Ausich and Sevastopulo, 2001). A total of six actinocrinitid genera are now recognized from Ireland, England, and Wales.

The primary source of confusion for understanding the systematics of North American (and other) actinocrinitids is that genus-level diagnostic characters that define European actinocrinitds have been applied as species-level diagnostic characters among North American forms. For example, ray grouping and lobation helps to define European genera, but this currently is used to differentiate North American species of Actinocrinites. Unfortunately, the solution for this is reassignment of many well-known North American species of “Actinocrinites” to other genera. Although inconvenient, this situation is not surprising, because many nineteenth century “catch-all” genera have been subdivided into numerous new genera, such as Cyathocrinites, Phanocrinus, Platycrinites, and Poteriocrinites. Recognition of well- 
defined genus concepts is a prerequisite for fully understanding the phylogeny, paleobiogeography, and evolutionary paleoecology of these crinoids.

This study is a continuation of the efforts to redefine the generic concepts of monobathrid camerates (Ausich and Kammer, 2008; Ausich and Kammer, 2009; Ausich and Kammer, 2010). Revising the camerates is an important step in compiling an accurate database to evaluate the evolutionary paleoecology of Mississippian crinoids, which will include an examination of the global, generic relationships between longevity, eurytopy, and evolutionary paleoecology of these crinoids (Ausich and Kammer, 2010). The camerates are of particular interest because they reached their peak diversity during the Tournaisian and are one of the most diverse groups of crinoids during this time (Kammer and Ausich, 2006; Sallan, et al., 2011).

In this contribution, the goals are to define all Actinocrinitidae genera with objective characters and to assign all North American species to the correct genus. This study looked at 125 North American species and 34 species and one species left in open nomenclature were reassigned to different genera (Table 2.1) and four species were designated as nomina dubia. This is only a first step for a full understanding of the Actinocrinitidae, but it does allow for evaluation of regional and global patterns of generic longevity, eurytopy, and evolutionary paleoecology. Significant evaluation of species-level systematics remains to be completed but is far beyond the scope of this study.

\section{SYSTEMATIC PALEONTOLOGY}

Where possible, all species were characterized by original descriptions and illustrations, subsequent descriptions and illustration of type specimens, and examination of type specimens. Complete synonymies are not provided as they are published in Webster (2003). Terminology 
follows Ubaghs (1978a) with modifications from Ausich et al. (1999) and open nomenclature that follows Matthews (1973).

Carboniferous startigraphy follows Heckel and Glayton (2005). Table 2.2 shows the detailed chronostratigraphic scheme and correlations that are used in this paper which follow Ausich and Kammer (2008).

This study focuses on the genera and species that are found in North America. Genera that are found outside of North America are described so that their characters can be fit within the family, but more detail is not added. Sixty-seven species found outside North America are mentioned, but their assignments are not verified. If an obvious error in generic placement was seen, it is noted, but no further investigation was done.

\section{Class Crinoidea Miller, 1821}

Subclass Camerata Wachsmuth and Springer, 1885

Order Monobathrida Moore and Laudon, 1943

Suborder Compsocrinina Ubaghs, 1978b

Superfamiy Periechocrinacea Bronn, 1849

Family Actinocrinitidae Austin and Austin, 1842

Discussion.—Bowsher and Ubaghs (1978) subdivided the Actinocrinitidae into four subfamilies: Actinocrinitinae Austin and Austin, 1842; Eumorphocrininae Ubaghs, 1978c; Cactocrininae Ubaghs, 1978d; and Physetocrininae Ubaghs, 1978e. A phylogenetic analysis was performed to investigate relationships between genera and to test if the previously named subfamilies represented actual clades. Phylogenetic relationships are inferred using parsimonybased character analysis of genera using PAUP (c)4.0b10 (Swofford, 2001). The actinocrinitid 
genera are defined using objective characters that define basic and distinctive characters found in of the calyx and tegmen. Seventeen characters with 68 character states were used to analyze the genera. These characters are unordered and unweighted; search methods were heuristic with random stepwise addition. Two trees were found under these conditions with a Rolf's consistency index (C.I.) of 0.56. The tree presented in this study (Fig. 2.1) is the one that places Manillacrinus in the clade with Cactocrinus as opposed to creating a polytomy with the clades containing Cactocrinus and Actinocrinites.

The outgroup used for this analysis are two genera from the Periechocrinidae Bronn, 1849 including Periechocrinus Morris, 1843, a Silurian and Devonian genus and Megistocrinus Owen and Shumard, 1852, a Devonian and Mississippian genus. Characters that are used for the outgroup genera are based on their type species, but the character states used for the Actinocrinitidae are based on all known species for each of the genera.

Only one subfamily defined by Ubaghs (1978b), the Actinocrinitinae, forms a clade in the phylogenetic analysis (Fig. 2.1) completed herein. The other three subfamilies are scattered throughout the tree. Thus, the subfamily classification of the Treatise (Ubaghs, 1978b) does not recognize monophyletic clades and should be abandoned.

Webster (2003) listed 21 genera in the family Actinocrinitidae; of these 21, five are not known in North America; one, Ancalocrinus Webster and Lane, 1987, was later included in the family Amphoracrinidae (Webster et al., 2004); and one, Diatorocrinus Wright, 1955, was synonymized into Actinocrinites (Ausich and Kammer, 2006). Ausich and Sevastopulo (2001) described two new genera of Actinocrinitidae, Iotacrinus and Thinocrinus, from Hook Head, Ireland. With these subtractions and additions, the present study recognizes 21 genera globally, with 17 recognized in North America. 
Wachsmuth and Springer (1897) subdivided the actinocrinitids into three primary groups that included: 1) genera with an anal tube, calyx lobed, and interradials in contact with the tegmen; 2) genera with an anal tube, calyx not lobed, and interradials not in contact with the tegmen; and 3) genera without an anal tube. Although these three groups are a good general way to subdivide the family, they do not represent any phylogenetic relationship between genera. For example, Physetocrinus and Strotocrinus Meek and Worthen, 1866 are the only known actinocrinitid genera without an anal tube, yet Strotocrinus is more closely related to Teleiocrinus Wachsmuth and Springer, 1881 than it is to Physetocrinus (Fig. 2.1).

The genus-level diagnostic characters for genera within Actinocrinitidae are defined as follows: calyx shape, basal circlet height, number of fixed secundibrachials, highest brachitaxis in the vertical wall of the calyx, number of ranges in the regular interrays, regular interrays in contact with tegmen, posterior interray in contact with tegmen, number of plates above the primanal, presence or absence of fixed interbrachials between half-rays, arms grouped, arm lobes, length of arm lobes, tegmen height compared to calyx, tegmen plate sculpture, tegmen shape, tegmen interrays depressed, and position of anal tube (Table 2.3).

One of the most distinct characters that separates genera within the actinocrinitids is the presence or absence of arm lobes. Arm lobes are extensions of the theca (calyx and tegmen) away from the distal portion of the calyx, formed by fixed brachials proximally and tegmen plates distally. All actinocrinitids that have arm lobes have arms that are strongly grouped and interrays that are in contact with the tegmen. This was the condition that Bowsher and Ubaghs (1978) used to distinguish the subfamily Actinocrinitinae; the same genera form a single clade in the phylogenetic tree (Fig. 2.1). When the theca is complete, the distinction is obvious, but if the arm trunks are broken, it could be impossible to know for certain whether or not arm trunks 
existed. Two other basic conditions exist among the actinocrinitids that lack arm trunks (i.e., where arms become free in a more-or-less circular pattern rather than being extended into arm lobes). Most actinocrinitids that lack arm lobes have arms that are either strongly or weakly grouped, allowing for the interrays to be in contact with the tegmen. In contrast, a few actinocrinitids have arm openings that are in continuous lateral contact, not allowing for interrays to connect with the tegmen. Examples of these conditions are as follows: Actinocrinites has long arm lobes, Aacocrinus has short arm lobes, Eumorphocrinus lacks arm lobes, but has a strong grouping of arm openings, Nunnacrinus lacks arm lobes and only has a slight grouping of arm openings, and Cactocrinus lacks arm lobes and all the arm facets are in lateral contact with one another.

Actinocrinitids that have arm lobes are Aacocrinus, Abactinocrinus, Actinocrinites, Blairocrinus, Iotacrinus, Sampsonocrinus, Steganocrinus, and Thinocrinus, and these genera form a distinct clade (Fig. 2.1). These crinoids can be distinguished based on the height of the basal circlet, length of arm lobes, number of plates in the vertical wall of the calyx, height of the tegmen, position of anal tube, and whether or not the tegmen is depressed in the interrays. Actinocrinites was first described by Miller (1821) with the type species Actinocrinites triacontadactylus from the Chadian of England. Among the English and Irish actinocrinitids, Actinocrinites is distinct because it is the only one that has arm lobes and fixed brachials in the vertical wall of the calyx that is higher than the primitaxis (Ausich and Sevastopulo, 2001). The Irish, English, and Welsh actinocrinitid generic assignments were revised by Ausich and Sevastopulo (2001) and Ausich and Kammer (2006).

North American species of Actinocrinites need to be reassigned based on the characters that define the genus. Many of species that have traditionally been in Actinocrinites lack arm 
lobes, only have primibrachials in the vertical calyx wall, or both. This is unfortunate due to how common Actinocrinites senso lato is and that it is easily identifiable with isolated radial plates or basal circlets. The only Actinocrinites sensu stricto that remain in North America are Actinocrinites grandissimus Van Sant, 1965, Actinocrinites jugosus (Hall, 1859), Actinocrinites lobatus (Hall, 1859), Actinocrinites magnificus (Wachsmuth and Springer, 1897); Actinocrinites monticuliferus (Miller and Gurley, 1894), and Actinocrinites spergenensis (Miller and Gurley, 1896).

The three more common actinocrinitids of North America are Aacocrinus Bowsher, 1955, Steganocrinus, Meek and Worthen, 1866, and Thinocrinus Ausich and Sevastopulo, 2001. All have calyces that are either a medium cone or a medium bowl shaped. Aacocrinus has short length arm lobes, a tegmen that is lower in height than the calyx, and an anal tube that is eccentric. Steganocrinus and Thinocrinus are easy to distinguish when the specimens are complete because Steganocrinus has long arm trunks along which the biserial arms are borne, and Thinocrinus has normal biserial free arms that leave the calyx from a fixed brachial. Unfortunately, most specimens are not complete and have either some or all of the arm lobes broken. Arms versus arm trunks must then be inferred and other characters considered. Thinocrinus has a tegmen that is lower than the calyx, the interrays on the tegmen are depressed, and the anal tube is central, whereas Steganocrinus has a tegmen that is as high as the calyx, interrays on the tegmen are not depressed, and the anal tube is eccentric. However, the most telling characteristic that distinguishes Steganocrinus from Thinocrinus (and other actinocrinitids) is that the first primibrachial flares outward and the second primibrachial (primaxil) is directed almost horizontally. In contrast, Thinocrinus has the first primibrachial in the calyx wall and the outflaring into arms begins with the primaxil or on the primaxil facet. 
The characters of where the primibrachial outflaring begins and the presence or absence of arm trunks are sufficient to diagnose most specimens between these two genera. Even though arm trunk preservation is extremely rare, it does not prevent the inference as to whether or not the trunk existed. In Steganocrinus the arm trunks divide from five to ten at a distance away from the calyx wall, whereas in Thinocrinus and other actinocrinitids, the rays divide into ten or more arms very close to the body wall. Because of the difference, in typical preservation (distal rays damaged or broken) a single ray opening is preserved in Steganocrinus and all other actinocrinitids preserve the ambulacral divisions either partially or completely.

Abactinocrinus Laudon and Severson, 1953 and Sampsonocrinus Miller and Gurley, 1895 both have medium bowl shaped calyces and depressions in the tegmen ineterrays. Abactinocrinus is more closely related to Thinocrinus based on phylogenetic analysis, and although Sampsonocrinus shares many of the same characters with both Abactinocrinus and Thinocrinus, it is separated by having an anal tube that is eccentric and not central.

Iotacrinus Ausich and Sevastopulo, 2001 is unique among the actinocrinitids with both arm lobes and a low bowl-shaped calyx. It is also one of only two of all the actinocrinitids to have a tegmen that can be higher than the calyx. Blairocrinus Miller, 1891 is the only genus where all known species have a higher tegmen than the calyx. It can be readily distinguished from Iotacrinus by having a low-cone shaped calyx and a central anal tube.

No other actinocrinitids have arm lobes, and most of the others cluster together in a single clade. This clade, which consists of Cactocrinus, Cusacrinus, Glaphyrocrinus, Ilmocrinus, Maligneocrinus, Manillacrinus, Nunnacrinus, Strotocrinus, and Teliocrinus.

Cactocrinus Wachsmuth and Springer, 1897, Ilmocrinus Solov'yeva, 1984, Strotocrinus Meek and Worthen, 1866, and Teleiocrinus Wachsmuth and Springer, 1881 are the only 
actinocrinitids that have arm openings that are in continuous lateral contact, completely separating the tegmen from the calyx. Teleiocrinus and Strotocrinus are distinguishable from the other two because they have a high number of ranges in the regular interrays (five or more), and the lack of an anal tube in Strotocrinus makes it the easiest to identify. The tegmen of Ilmocrinus is unknown, but the features of the calyx make it most similar to Cactocrinus, particularly in having only three ranges in the regular interrays, but it is separated from Cactocrinus in that the highest brachitaxis in the calyx wall is the tertibrachitaxis whereas in Cactocrinus, the highest brachitaxis is the secundibrachitaxis.

The other actinocrinitids in this clade have grouped arms. Manillacrinus Campbell and Bein, 1971 and Glaphyrocrinus Lindley, 1988 have arms that are strongly grouped. Glaphyrocrinus has two fixed secundibrachials and four ranges in the regular interrays, whereas Manillacrinus has only one fixed secundibrachial and three ranges in the regular interrays.

Nunnacrinus Bowsher, 1955, Cusacrinus Bowsher, 1955 and Maligneocrinus Laudon, Parks, and Spreng, 1952 have weakly grouped arms. Cusacrinus and Nunnacrinus are very similar to one another, but Nunnacrinus distinguishes itself within the clade by having the primibrachitaxis as the highest brachitaxis in the calyx; the highest brachitaxis in Cusacrinus is the secundibrachitaxis. Maligneocrinus is unique among the actinocrinitids in being the only one that has a globe-shaped calyx.

Eumorphocrinus Wright, 1955 and Cytidocrinus Kirk, 1944 are the most primitive of the actinocrinitids because they lack fixed intrabrachials between half-rays. This feature can occurs in a few of the lobed forms, but most of the actinocrinitids lack it. The two genera are easily distinct from one another as Eumorphocrinus has smooth tegmen plates, two fixed secundibrachials, the tertibrachitaxis is highest in the calyx wall, and five or more ranges in the 
regular interrays. In contrast, Cytidocrinus has spinose tegmen plates, no fixed secundibrachials, the primibrachitaxis is the highest in the calyx wall, and there are only four ranges in the regular interrays.

On the phylogenic diagram (Fig. 2) Physetocrinus Meek and Worthen, 1869 and Dialutocrinus Wright, 1955 are ladderized between Eumorphocrinus/Cytidocrinus and more advanced actinocrinitids. Physetocrinus is distinct in having weakly to strongly grouped arms with no anal tube. Dialutocrinus does not have any characters that are unique to the genus, but rather a conglomeration of characters that it shares with various groups. Dialutocrinus shares many characters with the clade that includes Cactocrinus including lack of arm lobes, the tertibrachitaxis being the highest brachitaxis in the vertical wall of the calyx, and having fixed interbrachials between half-rays. However, a medium bowl calyx shape is not common in the Cactocrinus clade and neither is having three ranges in the regular interrays. As a result, Dialutocrinus separates away from the other genera of actinocrinitids.

The Actinocrinitidae is a group that mostly existed within the Mississippian, although it originated during the Famennian and ranged through the Bashkirian. Geographically, the actinocrinitids are recognized in North America, Western Europe, North Africa, Russia, China, Japan, and Australia. There are also reports that this family from in the Permian of Indonesia and Australia, but more work needs to be done with the Permian taxa and it unknown exactly where they fit within the family, if at all. Clearly more work needs to be completed on the Actinocrinidae elsewhere the world. 
Genus Actinocrinites Miller, 1821

Type species.-Actinocrinites triacontadactylus Miller, 1821, by subsequent designation (Wachsmuth and Springer, 1881).

Other species.-European species include: Actinocrinites aculeatus Austin and Austin, 1842; Actinocrinites alatus Wright, 1955a; Actinocrinites batheri (Whidborne, 1896); Actinocrinites caryocrinoides (M’Coy, 1844); Actinocrinites comptus Wright, 1955a; Actinocrinites constrictus (M’Coy, 1844); Actinocrinites coplowensis Wright, 1955a; Actinocrinites costus (M’Coy, 1844); Actinocrinites decadactylus (Gilberston in Portlock, 1843); Actinocrinites depressus Wright, 1955a; Actinocrinites elongates Wright, 1955a; Actinocrinites goldfussi (Schmidt, 1930); Actinocrinites granulatus Goldfuss, 1831 Actinocrinites intermedius Wright, 1955a; Actinocrinites laevis Miller, 1821; Actinocrinites moderatus Wright, 1955a; Actinocrinites nodosus Wright, 1955a; Actinocrinites parkinsoni Wright, 1955a; Actinocrinites pusillus (M’Coy, 1844); Actinocrinites rotundatus Wright, 1955a; Actinocrinites tenuis (de Koninck and Le Hon, 1854); Actinocrinites tenuistriatus (Phillips, 1841); Actinocrinites tricuspidatus (de Koninck and Le Hon, 1854); Actinocrinites tripus Ehlers and Kesling, 1963; and Actinocrinites vermiculatus Wright, 1955a.

North American species include Actinocrinites grandissimus Van Sant, 1965; Actinocrinites jugosus (Hall, 1859); Actinocrinites lobatus (Hall, 1859); Actinocrinites magnificus (Wachsmuth and Springer, 1897); Actinocrinites monticuliferus (Miller and Gurley, 1894); Actinocrinites spergenensis (Miller and Gurley, 1896); and Actinocrinites sp. (Brower, 1970) [new combination].

Additionally, Actinocrinites higuchisawensis (Minato, 1951) and Actinocrinites ohmoriensis (Minato, 1951) have been described in Japan; ?Actinocrinites polydactylus Miller, 
1821 from Australia; Actinocrinites skourensis (Termier and Termier, 1950) from Morocco; Actinocrinites zhaoae (Lane, et al., 1997) from China; Actinocrinites becharensis Webster, et al., 2004; and Actinocrinites combinatus Webster, et al., 2004 from Algeria.

Diagnosis.—Calyx shape medium cone or high bowl; basal circlet high; one fixed secundibrachial; secundibrachitaxis or higher highest brachitaxis in vertical wall of calyx; three ranges in regular interray; regular interray in contact with tegmen; posterior interray in contact with tegmen; fixed intrabrachials between half-rays present or absent; arms strongly grouped; arm lobes present and extend laterally; arm lobes long; tegmen lower than calyx; plates on tegmen nodose; tegmen shape low to high cone or low inverted bowl; tegmen interray not depressed; anal tube central.

Occurrence.-This genus occurs in the Osagean of Indiana, Illinois, Iowa, Tennessee, Kentucky, Missouri, Colorado, and Arizona as well as the Meramecian of Indiana in North America. It also occurs in the Famennian of England and China; the Tournasian of Scotland, Ireland, England, Belgium, and Japan; the Visean of Germany, Morocco, and Belgium; and the Serpukhovian of Algeria.

Discussion.—Brower (1970) questionably assigned a specimen to the genus Eumorphocrinus, but the known characters of this specimen better fit the genus Actinocrinites. Actinocrinites sp. has a conical calyx, the half rays are separated by intrabrachials, and what is known of the tegmen indicates that it is a low cone. Eumorphocrinus does not have these characters, having a medium bowl shaped calyx, no fixed intrabrachials between half-rays, and a low inverted bowl shaped tegmen.

Actinocrinites marcoui Collignon, 1924 is considered a nomen dubium because the only illustration of it is a plate diagram. Although the plate diagram may be accurate, it does not 
illustrate specimens of the species; and therefore, it cannot be compared to other species within the genus.

Several species of crinoids that were assigned to the genus Actinocrinites by Wanner (1924, 1937) from Timor and Australia are not included in the list above but are included in Webster (2003). These species may be a holdover of the actinocrinitids, but it is unlikely that they belong to this genus. There is still much work that needs to be done on them, but that is beyond the scope of this paper so they will not be included here.

Genus Aacocrinus Bowsher, 1955

Type species.-Aacocrinus nododorsatus Bowsher, 1955, by original designation.

Other species.—North American species include Aacocrinus boonensis (Peck and Keyte, 1938); Aacocrinus chouteauensis (Miller, 1892); Aacocrinus enigmaticus Webster and Lane, 1897; Aacocrinus protuberoarmatus Brower, 1967; Aacocrinus sampsoni (Miller and Gurley, 1895); Aacocrinus senectus (Miller and Gurley, 1897); Aacocrinus spinosulus (Miller and Gurley, 1893); and Aacocrinus tetradactylus Brower, 1967.

Non-North American species include Aacocrinus acylus Webster and Jell, 1999 and Aacocrinus algeriaensis Webster et al., 2004.

Diagnosis.—Calyx shape medium cone to medium bowl; basal circlet low; zero, one, or two fixed secundibrachials; primibrachitaxis or secundibrachitaxis highest brachitaxis in vertical wall of calyx; three ranges in regular interray; regular interray in contact with tegmen; posterior interray in contact with tegmen; fixed intrabrachials between half-rays absent; arms strongly grouped; arm lobes present and extend laterally; arm lobes short; tegmen lower than calyx; plates 
on tegmen nodose; tegmen shape flat cone or low inverted bowl; tegmen interray not depressed; anal tube eccentric

Occurrence.-This genus occurs in the Kinderhookian of Missouri and the Osagean of New Mexico and Nevada. It also occurs in the Tournaisian or Visean of Australia and the Bashkirian of Algeria.

Discussion.-Aacocrinus is a genus known mostly from North America, though A. acylus has been described in Australia (Webster and Jell, 1999) and A. algeriaensis has been described in Algeria (Webster et al., 2004). Brower (1967) thoroughly described this genus, which will not be repeated here.

Aacocrinus triarmatus Brower, 1967 was named for two specimens that are poorly preserved. One specimen is very small (only $4 \mathrm{~mm}$ ), a possible juvenile, and lacks a tegmen, and the other is a set of isolated arms. The conditions of these two specimens are too poor to confidently assign a new species to them and therefore A. triarmatus is designated as nomen dubium.

Genus Abactinocrinus Laudon and Severson, 1953

Type species.-Abactinocrinus rossei Laudon and Severson, 1953, by original designation.

Other species._-Abactinocrinus devonicus Waters et al. 2003.

Diagnosis.—Calyx shape medium bowl; basal circlet low; one fixed secundibrachial; primibrachitaxis highest brachitaxis in vertical wall of calyx; three ranges in regular interray; regular interray in contact with tegmen; posterior interray in contact with tegmen; fixed intrabrachials between half-rays absent; arms strongly grouped; arm lobes present and extend 
laterally; arm lobes long; tegmen lower than calyx; plates on tegmen nodose; tegmen shape flat inverted bowl; tegmen interray depressed; anal tube central.

Occurrence.--This genus occurs in the Kinderhookian of Montana and the Famennian of China.

Discussion.-The discovery of Abactinocrinus devonicus in the Famennian of China makes this genus among the oldest of the actinocrinitids along with Actinocrinites (also found in the same Chinese rocks) and Eumorphocrinus from the Devonian of England. Brower (1967) thoroughly described this genus.

Genus Blairocrinus Miller, 1891

Type species._- Blairocrinus trijugis Miller, 1891 by original designation.

Other species.—North American species include Blairocrinus arrosus Miller, 1892; Blairocrinus macurdai Rhenberg and Kammer, ms; Blairocrinus protuberus Lee et al., 2005; and Blairocrinus smalleyi (Weller, 1909) [new combination].

Non-North American species include Blairocrinus grafensis Webster et al., 2004.

Diagnosis.—Calyx shape low cone; basal circlet low; one fixed secundibrachial; primibrachitaxis highest brachitaxis in vertical wall of calyx; two ranges in regular interray; regular interray in contact with tegmen; posterior interray in contact with tegmen; fixed intrabrachials between half-rays absent; arms strongly grouped; arm lobes present and extend laterally; arm lobes short; tegmen higher than calyx; plates on tegmen nodose, smooth, or with proximal spines; tegmen shape low to high cone or medium inverted bowl; tegmen interray not depressed; anal tube central. 
Occurrence.-This genus occurs in the Kinderhookian of Missouri and the Osagean of Kentucky, Missouri, and New Mexico. It also occurs in the Bashkirian of Algeria.

Discussion.-Blairocrinus is the only actinocrinitid that has a tegmen that is higher than the calyx, which makes it easy to distinguish from the other actinocrinitids.

Physetocrinus smalleyi is reassigned to Blairocrinus based on the characters that match it to the latter genus. These characters are the tegmen is higher than the calyx and the arms are strongly grouped and occur in short arm lobes. In Weller's (1909) description, he stated that there was no anal tube, but his illustrations indicate that the beginning of one located centrally on the tegmen and broken off.

Blairocrinus arrosus is a species that is subject to much confusion. This confusion stems from S. A. Miller assigning two actinocrinitids with the species name "arrosus": Blairocrinus arrosus Miller, 1892 and Actinocrinites arrosus Miller and Gurley, 1893. Without presenting a complete history of the confusion, Bassler and Moodey (1943) assigned the 1892 species to Actinocrinites, and they left the 1894 species in Actinocrinites with a note that said it probably belonged in Cactocrinus. Webster (2003) considered both species to be in Cactocrinus (with $B$. arrosus also considered in the genus Aacocrinus), and presumably, synonymous homonyms. However, B. arrosus was correctly assigned to Blairocrinus by Miller (1892), as regarded by Brower (1967) and Lee et al. (2005). Actinocrinus arrosus Miller and Gurley, 1893 was correctly assigned to Cactocrinus.

Genus Cactocrinus Wachsmuth and Springer, 1897 Type species.-Actinocrinus proboscidialis Hall, 1858; by original designation. 
Other species.—Cactocrinus arrosus (Miller and Gurley, 1893); Cactocrinus bacatus Wood, 1914; Cactocrinus bischoffi (Miller and Gurley, 1896c) [new combination]; Cactocrinus clarus (Hall, 1861a); Cactocrinus extensus Wachsmuth and Springer, 1897; Cactocrinus fossatus (Miller, 1892a); Cactocrinus glans (Hall, 1859a); Cactocrinus hurdianus (McChesney, 1861) [new combination]; Cactocrinus imperator (Laudon, 1933) [new combination]; Cactocrinus lucina (Hall, 1861b); Cactocrinus magnidactylus Laudon and Severson, 1953; Cactocrinus multibrachiatus (Hall, 1858); Cactocrinus obesus (Keyes, 1894c); Cactocrinus opusculus (Hall, 1859a); Cactocrinus platybrachiatus (Wood, 1914); Cactocrinus sexarmatus (Hall, 1859a); Cactocrinus springeri (Rowley, 1900a); and Cactocrinus thalia (Hall, 1861b).

Diagnosis.—Calyx shape medium cone; basal circlet low; one fixed secundibrachial; secundibrachitaxis highest brachitaxis in vertical wall of calyx; two or three ranges in regular interray; regular interray not in contact with tegmen; posterior interray not in contact with tegmen; fixed intrabrachials between half-rays present; arms not grouped; arm lobes absent; tegmen lower than or same height as calyx; plates on tegmen smooth or spinose; tegmen shape low to medium cone or low inverted bowl; tegmen interray depressed; anal tube central.

Occurrence.-This genus is known from the Kinderhookian of Missouri; the Osagean of Iowa, Missouri, Illinois, New Mexico, and Utah.

Discussion.-Cusacrinus bischoffi, C. hurdianus, and C. imperator are reassigned to Cactocrinus because the arms are not grouped and the arm facets are connected to each other not allowing the interrays to be in contact with the tegmen.

Cactocrinus excerptus (Hall, 1861a) has neither been illustrated nor have any type specimens been located for study. Until type specimens are found, C. excerptus is regarded a nomen dubium. Cactocrinus fosteri (McChesney, 1861) is also considered a nomen dubium. 
This species name was assigned to a specimen that did not have a tegmen and the illustration is all that remains of the original type; the types were lost in the Chicago fire of 1871 (Wachsmuth and Springer, 1897).

Genus Cusacrinus Bowsher, 1955

Type species.—Actinocrinites nodobrachiatus Wachsmuth and Springer in Miller, 1889; by original designation.

Other species.-Cusacrinus arnoldi (Wachsmuth and Springer in Miller, 1889); Cusacrinus asperrimus (Meek and Worthen, 1870); Cusacrinus chloris (Hall, 1861); Cusacrinus coelatus (Hall, 1858); Cusacrinus daphne (Hall, 1863b); Cusacrinus denticulatus (Wachsmuth and Springer, 1897); Cusacrinus ectypus (Meek and Worthen, 1870a); Cusacrinus kuenzii (Laudon et al., 1952); Cusacrinus limabrachiatus (Hall, 1861a); Cusacrinus longus (Meek and Worthen, 1870); Cusacrinus ornatissmus (Wachsmuth and Springer in Miller, 1889); Cusacrinus penicillus (Meek and Worthen, 1870); Cusacrinus sampsoni (Miller and Gurley, 1896c) [new combination]; Cusacrinus sobrinus (Miller and Gurley, 1896c) [new combination]; Cusacrinus spectabilis (Miller and Gurley, 1896c) [new combination]; Cusacrinus spinotentaculus (Hall, 1859); Cusacrinus subscitulus (Miller and Gurley, 1896c) [new combination]; Cusacrinus tenuisculptus (McChesney, 1861); Cusacrinus thetis (Hall, 1861); Cusacrinus tuberculosus (Wachsmuth and Springer, 1897); Cusacrinus viaticus (White, 1874).

Diagnosis.-Calyx shape low to medium cone; basal circlet high or low; one fixed secundibrachial; secundibrachitaxis highest brachitaxis in vertical wall of calyx; four ranges in regular interray; regular interray in contact with tegmen; posterior interray in contact with tegmen; fixed intrabrachials between half-rays present; arms weakly grouped; arm lobes absent; 
tegmen lower than or same height as calyx; plates on tegmen smooth or spinose; tegmen shape flat cone, low to medium cone, or low inverted bowl; tegmen interray not depressed; anal tube central.

Occurrence.-This genus occurs in the Kinderhookian of Iowa, Ohio, Montana, Utah, and Alberta, Canada as well as the Osagean of Iowa, Missouri, New Mexico, and Nevada.

Discussion.-Actinocrinites sobrinus, A. spectabilis, and A. subscitulus are reassigned to Cusacrinus due to the lack of arm lobes, arms that are weakly grouped, correct number of ranges in the regular interrays, and the tegmen plate sculpture. It is possible that all three of these species are variations on one species. They all occur in the Burlington Limestone, and the differences between them appear to be minor. Miller and Gurley (1896c) even noted that they frequently found differences in the number of interradial plates among specimens of the same species, which is one of their distinguishing characters to separate $C$. spectabilis [new comb.] and $C$. sobrinus [new comb.]. The other determining character between the two species is that the regular interrays are not in contact with the tegmen.

Cusacrinus arnoldi and C. ornatissimus were synonymized with C. nodobrachiatus in Webster's Index (2003), however there is no explanation as to why these three species should be considered the same. All three species are distinguishable from each other and should remain separate. Cusacrinus nodobrachiatus has steep sided, medium-cone shaped calyx, low basals, and spinose plates on the tegmen. Whereas $C$. arnoldi has the medium-cone shaped calyx, the sides are not so steep, the basals are higher, and the tegmen plates are smooth. Cusacrinus ornatissimus has a low-cone shaped calyx, making it different that the previous two, low basals, and the tegmen is unknown. 
Nunnacrinus sampsoni has been placed in Cusacrinus because the highest brachitaxis in the calyx is the secundibrachitaxis. The highest brachitaxis in Nunnacrinus is the primibrachitaxis.

\section{Genus Cytidocrinus Kirk, 1944}

Type species.-Actinocrinus sculptus Hall, 1858 by original designation.

Diagnosis.—Calyx shape medium bowl; basal circlet high; zero fixed secundibrachials; primibrachitaxis highest brachitaxis in vertical wall of calyx; four ranges in regular interray; regular interray in contact with tegmen; posterior interray in contact with tegmen; fixed intrabrachials between half-rays absent; arms strongly grouped; arm lobes absent; tegmen lower than calyx; plates on tegmen spinose; tegmen shape low inverted bowl; tegmen interray not depressed; anal tube central.

Occurrence.-This genus occurs in the Osagean of Missouri and Iowa; it has been reported in New Mexico, but this is not confirmed.

Discussion.-The genus Cytidocrinus is fully described by Kirk (1943a, p. 263).

Genus Dialutocrinus Wright, 1955

Type species.—Dialutocrinus milleri Wright, 1955.

Other species.—European species include Dialutocrinus aculeatus (Austin and Austin, 1843); Dialutocrinus austini Ausich and Sevastopulo, 2001; Dialutocrinus icosidactylus (Portlock, 1843); Dialutocrinus mcoyi Ausich and Sevastopulo, 2001; Dialutocrinus polydactylus (Miller, 1821); and Dialutocrinus tessellatus (Phillips, 1836). 
North American species include Dialutocrinus? gracilis (Wachsmuth and Springer, 1897) [new combination].

Diagnosis.—Calyx shape medium bowl; basal circlet high or low; one fixed secundibrachial; tertibrachitaxis highest brachitaxis in vertical wall of calyx; three ranges in regular interrays; regular interrays in contact with tegmen; posterior interray in contact with tegmen; fixed intrabrachials between half-rays present; arms strongly or weakly grouped; arm lobes absent; tegmen lower than calyx; plates on tegmen nodose; tegmen shape low cone or low inverted bowl; tegmen interray not depressed; anal tube central.

Occurrence.-This genus occurs in the Osagean of Iowa and the late Tournaisian of England, Ireland, Belgium, France, and Germany.

Discussion.-Cusacrinus gracilis is questionably reassigned to Dialutocrinus because the calyx shape is a bowl and not a cone. There are also only three ranges of plates in the regular interray, not four which is what it would be if it were a Cusacrinus. However, the secundibrachtaxis is the highest brachitaxis in the vertical wall, which does not fit the characters seen in Dialutocrinus. The tegmen is not known for $D$. gracilis [new comb.], but the calyx features best fit Dialutocrinus. The reassignment of $D$. gracilis brings Dialutocrinus to North America, whereas before it has only been known in western Europe.

\section{Genus EumorpHOcRINus Wright, 1955}

Type species.—Eumorphocrinus erectus Wright, 1955.

Other species.—Eumorphocrinus elongates Lindley, 1979; Eumorphocrinus excelsus Wright, 1955; and Eumorphocrinus hibernicus Wright, 1955. Devonian species includes Eumorphocrinus porteri (Whidborne, 1896). 
Diagnosis.—Calyx shape medium bowl; basal circlet high; two fixed secundibrachials; tertibrachitaxis highest brachitaxis in vertical wall of calyx; five or more ranges in regular interrays; regular interrays in contact with tegmen; posterior interray in contact with tegmen; fixed intrabrachials between half-rays absent; arms strongly grouped; arm lobes absent; tegmen lower than calyx; plates on tegmen smooth; tegmen shape low inverted bowl; tegmen interray not depressed; anal tube central.

Occurrence.—Famennian of England; late Tournaisian, Visean of Scotland, Ireland, and New South Wales, Australia.

Genus GLaphyrocrinus Lindley, 1988

Type species.—Glaphyrocrinus expansus Lindley, 1988.

Other species.—Glaphyrocrinus minutus Lindley, 1988.

Diagnosis.—Calyx shape medium cone; basal circlet high; two fixed secundibrachials; secundibrachitaxis highest brachitaxis in vertical wall of calyx; four ranges in regular interray; regular interray in contact with tegmen; posterior interray in contact with tegmen; fixed intrabrachials between half-rays present; arms strongly grouped; arm lobes absent; tegmen lower than calyx; few large sized tegmen plates; plates on tegmen nodose; tegmen shape low inverted bowl; tegmen interray not depressed; anal tube central.

Occurrence.-Visean of New South Wales, Australia.

Genus ILmocrinus Solov’yeva, 1984

Type species.—Ilmocrinus dissymmetricus Solov'yeva, 1984. 
Diagnosis.—Calyx shape low to medium bowl; basal circlet low; one fixed secundibrachial; tertibrachitaxis highest brachitaxis in vertical wall of calyx; two ranges in regular interray; regular interray not in contact with tegmen; posterior interray not in contact with tegmen; fixed intrabrachials between half-rays present; arms not grouped; arm lobes absent; tegmen height unknown; tegmen plate size unknown; tegmen plate sculpture unknown; tegmen shape unknown; tegmen interray depression unknown; anal tube unknown.

Occurrence.—Late Visean, Serpukhovian, Russia

Genus IotaCrinus Ausich and Sevastopulo, 2001

Type species.—Actinocrinus dorsatus (de Koninck and LeHon, 1854) by original designation.

Other species.—Iotacrinus novamexicana Rhenberg and Kammer, ms.

Diagnosis.—Calyx shape low bowl; basal circlet low; one fixed secundibrachial; tertibrachitaxis highest brachitaxis in vertical wall of calyx; three ranges in regular interrays; regular interrays in contact with tegmen; posterior interray in contact with tegmen; fixed intrabrachials between half-rays absent; arms strongly grouped; arm lobes present and extend laterally; arm lobes medium in length; tegmen lower or higher than calyx; many medium sized tegmen plates; plates of tegmen nodose; tegmen shape low inverted bowl; tegmen interray not depressed; anal tube eccentric.

Occurrence.-Nunn Member of the Lake Valley Formation (Early Osagean) of New Mexico; Tournaisian of Ireland and Belgium.

Discussion.—Until a recent review of the Lake Valley Formation crinoids, Iotacrinus was only known in the "Mountain Limestone" of Belgium and in the Hook Head Formation of 
Ireland (Ausich and Sevastopulo, 2001). The North American species, Iotacrinus

novamexicana, is similar to the European species but has a tegmen that is much higher and is more distinctly lobed.

Genus Maligneocrinus Laudon, Parks, and Spreng, 1952

Type species.—Maligneocrinus medicinensis Laudon, Parks, and Spreng, 1952.

Diagnosis.—Calyx shape medium globe; basal circlet low; one fixed secundibrachial; tertibrachitaxis highest brachitaxis in vertical wall of calyx; five or more ranges in regular interray; regular interray in contact with tegmen; posterior interray in contact with tegmen; fixed intrabrachials between half-ray present; arms weakly grouped; arm lobes absent; tegmen lower than calyx; tegmen plate sculpture unknown; tegmen shape unknown; tegmen interray depression unknown; anal tube unknown.

Occurrence.-This genus occurs in the Kinderhookian of Alberta.

Discussion.-Although this genus is known only from partial crowns, the calyx shows the characteristics of actinocrinitids, making it a definite fit for this family. Maligneocrinus does not fit into other actinocrinitid genera due to its globe shaped calyx. It is the only known actinocrinitid with this particular calyx shape.

Genus ManilLacrinus Campbell and Bein, 1971

Type species.-Cactocrinus? brownei Dun and Benson, 1920; by original desgination. Other species.—Manillacrinus acanthus Webster and Jell, 1999. Campbell and Bein (1971) also describe Manillacrinus sp. 
Diagnosis.—Calyx shape medium cone; basal circlet high; one fixed secundibrachial; secundibrachitaxis highest brachitaxis in vertical wall of calyx; three ranges in regular interray; regular interray in contact with tegmen; posterior interray in contact with tegmen; fixed intrabrachials between half-rays present; arms strongly grouped; arm lobes absent; tegmen lower than or same height as calyx; plates on tegmen nodose; tegmen shape medium cone; tegmen interray not depressed; anal tube central.

Occurrence.-Tournaisian of New South Wales, Australia.

Discussion.—It should be noted that Bowsher (in Moore and Teichert, 1978, p. T458) erroneously refers to this genus as Manillocrinus.

Genus NunNaCrinus Bowsher, 1955

Type species.—Nunnacrinus mammillatus Bowsher, 1955; by original designation.

Other species.—North American species include Nunnacrinus dalyanus (Miller, 1881); Nunnacrinus eraticus (Miller and Gurley, 1893) [new combination]; Nunnacrinus foveatus (Miller and Gurley, 1895); Nunnacrinus jessieae (Miller and Gurley, 1897); Nunnacrinus locellus (Hall, 1861); Nunnacrinus ovatus (Hall, 1861) [new combination]; Nunnacrinus pallubrum (Miller and Gurley, 1896b); Nunnacrinus pettisensis (Miller and Gurley, 1896c); Nunnacrinus plagosus (Miller and Gurley, 1893) [new combination]; Nunnacrinus puteatus (Rowley and Hare, 1891); Nunnacrinus reticulatus (Hall, 1861) [new combination]; and Nunnacrinus rubra (Weller, 1909).

European species include Nunnacrinus armatus (de Koninck and Le Hon, 1854); Nunnacrinus deornatus (de Koninck and Le Hon, 1854); Nunnacrinus dorsatus (de Koninck and Le Hon, 1854); and Nunnacrinus stellaris (de Koninck and Le Hon, 1854). 
Diagnosis.-Calyx shape low to medium cone; basal circlet low; one fixed secundibrachial; primibrachitaxis highest brachitaxis in vertical wall of calyx; four ranges in regular interray; regular interray in contact with tegmen; posterior interray in contact with tegmen; fixed intrabrachials between half-rays present; arms weakly grouped; arm lobes absent; tegmen lower than or same height as calyx; plates on tegmen nodose or spinose; tegmen shape medium cone or low inverted bowl; tegmen interray not depressed; anal tube central.

Occurrence.-This genus is known from the Kinderhookian of Missouri; the Osagean of Iowa, Missouri, and New Mexico; and the Tournaisian of Belgium.

Discussion.—When Bowsher (1955) named the genus Nunnacrinus, he designated the type species as being $N$. mammillatus. This species is known only to occur in the Nunn Member of the Lake Valley Formation. However, this species is the same as a species already named in the Lake Valley Formation, N. dalyanus (Miller, 1881). Bowsher (1955, p. 20) said that the two species are distinguishable from each other most readily by the number of plates that separate the rays: $N$. mammillatus having two plates that separate the rays and $N$. dalyanus having only one plate that separates the rays. This distinction is not valid as there is variation in plate number between rays in more than 700 Nunnacrinus specimens studied from the Lake Valley, including the types for N. mammillatus (Appendix 3). Most of the specimens have both single and double plates between the rays and not just one or the other. The other ways that Bowsher separated $N$. mammillatus and $N$. dalyanus also have great variation among the specimens studied. These characters include $N$. mammillatus being smaller in size, having less conical calyx and tegmen, weaker plate structure on the calyx, and great irregularity of size of tegmen plates. All of these features have the range of variability with one species of crinoid. Because of this, $N$. mammillatus is a junior synonym of $N$. dalyanus. 
Actinocrinus erraticus and A. plagosus are reassigned to Nunnacrinus because the arms are weakly grouped, do not form lobes, and have the correct number of ranges in the interrays. Although the tegmen is not known for $N$. plagosus [new comb.], the calyx characters best fit Nunnacrinus.

Cactocrinus reticulatus and C. reticulatus ovatus are reassigned to Nunnacrinus because the interrays connect with the tegmen, which is not a character for Cactocrinus. Furthermore, $N$. ovatus [new comb.] is returned to a separate species and not a variation of $N$. reticulatus [new comb.]. Wachsmuth and Springer (1897) said that $N$. ovatus was a variation of $N$. reticulatus but the illustrations do not have enough similarities to be the same species. Both species have the medium-shaped cone, but $N$. ovatus has a more rounded overall shape, almost boarding on a bowl shaped calyx. Nunnacrinus reticulatus has a medium-cone shaped tegmen that is about the same height as the calyx with long spines on most of the tegmen plates, including the plates that form the base of the anal tube. Nunnacrinus ovatus has a low inverted bowl shaped calyx with short spines on a few of the tegmen plates; the spines do not appear to continue up the anal tube.

One problem Nunnacrinus is $N$. jessieae. In 1896, Miller and Gurley described several new camerate crinoids, and two were given the trivial name "jessieae", Actinocrinites jessieae Miller and Gurley, 1896a and Amphoracrinus jessieae Miller and Gurley, 1896c. Webster (2003) synonymized both of these species as $N$. jessieae, although they are two very distinct species. Bowsher (1955) correctly placed Actinocrinites jessieae as Nunnacrinus and Ausich and Kammer (2008) considered Amphoracrinus jessieae to be a nomen dubium.

Bowsher (1955) placed four species from Europe into the genus Nunnacrinus ( $N$. armatus, $N$. deornatus, $N$. dorsatus, and $N$. stellaris). These species, however, are unlikely to 
belong to this genus, but will remain here as non-North American species are not within the scope of this study to verify.

Genus Physetocrinus Meek and Worthen, 1869

Type species.- Actinocrinus ventricosus Hall, 1858; by subsequent designation (Wachsmuth and Springer, 1881).

Other species.—North American species include Physetocrinus asper (Meek and Worthen, 1870); Physetocrinus copei (Miller, 1881); Physetocrinus dilatatus (Meek and Worthen, 1870); Physetocrinus lobatus Wachsmuth and Springer, 1897; Physetocrinus majusculus Webster and Lane, 1987; and Physetocrinus ornatus (Hall 1858).

European species include Physetocrinus brightoni Wright, 1955.

Diagnosis.—Calyx shape medium cone to medium bowl; basal circlet high; one fixed secundibrachial; secundibrachitaxis or tertibrachitaxis highest brachitaxis in vertical wall of calyx; four ranges in regular interray; regular interray in contact with tegmen; posterior interray in contact with tegmen; fixed intrabrachials between half-rays present; arms strongly to weakly grouped; arm lobes absent; tegmen lower than calyx; plates on tegmen smooth; tegmen shape flat to low inverted bowl; tegmen interray not depressed; anal tube absent, opening eccentric

Occurrence.-This genus is known from the Kinderhookian of Iowa and Missouri, the Osagean of Iowa, Illinois Missouri, New Mexico, Arizona, and Nevada and the Tournaisian of Ireland.

Discussion.—Physetocrinus is mostly known from North America, although one species, P. brightoni, occurs in the Hook Head Formation of Ireland. This species is most similar to the North American species, P. lobatus, which is present in New Mexico and Arizona. 
The species Physetocrinus majusculus is questionably kept as a separate species from $P$. copei. The main difference cited by Webster and Lane (1987) between the two species is that $P$. majusculus has a more highly inflated tegmen than P. copei. A study on P. copei from the Lake Valley Formation indicates that there is a wide variation of tegmen inflation in that species (fig. WWWW in Rhenberg and Kammer, ms). Otherwise, the differences between the two species are minute. These differences include $P$. majusculus having a more conical calyx, a weak overhang at the base of the arms, fewer plates separating the ambulacral tracts between rays and half-rays, and more uniform tegmen plates. However, until a more detailed study on the species can be done, they will remain separate species.

Genus Sampsonocrinus Miller and Gurley, 1895

Type species.—Sampsonocrinus hemisphericus Miller and Gurley, 1895

Other species.—North American species include Sampsonocrinus? globosus

(Wachsmuth and Springer, 1897); and Sampsonocrinus sedaliensis (Miller and Gurley, 1895) [new combination].

Non-North American species include Sampsonocrinus cannindahensis Webster and Jell, 1999 and Sampsonocrinus cheguigaensis Webster et al., 2004.

Diagnosis.—Calyx shape medium bowl; basal circlet low; fixed secundibrachial number unknown; primibrachitaxis highest brachitaxis in vertical wall of calyx; two ranges in regular interray; regular interray in contact with tegmen; posterior interray in contact with tegmen; fixed intrabrachials between half-rays present; arms strongly grouped; arm lobes present and extend laterally; arm lobes short; tegmen lower than calyx; plates on tegmen nodose; tegmen shape flat to low inverted bowl; tegmen interrays depressed; anal tube eccentric. 
Occurrence.-This genus occurs in the Kinderhookian of Missouri, the Visean of Queensland, Australia, and the Bashkirian of Algeria.

Discussion.—Actinocrinus sedaliensis is reassigned to the genus Sampsonocrinus because the characters better fit the latter genus. The species has a low basal circlet, two ranges in the regular interrays, and an eccentric anal tube.

The species Sampsonocrinus? globosus is a problematic species in that it does not conform to any known crinoid genus. Brower (1965, pg. 789) discusses this issue, suggesting it may be a new genus of actinocrinitid. As the species is known from a single specimen, he hesitated to name a new genus and concluded that it is most similar to Sampsonocrinus and questionably placed it within this genus. With no new information to add, we follow Brower's suggestion and leave S. globosus where it is.

Genus Steganocrinus Meek and Worthen, 1866a

Type species.—Actinocrinites pentagonus Hall, 1858; by original designation.

Other species.—Steganocrinus altus Brower, 1965; Steganocrinus? burlingtonensis

Brower, 1965; Steganocrinus concinnus (Shumard, 1855); Steganocrinus elongatus Kirk, 1943; Steganocrinus longus Brower, 1965; Steganocrinus multistriatus Brower, 1965; Steganocrinus planus Brower, 1965; Steganocrinus robustus Brower, 1965; and Steganocrinus validus (Meek and Worthen; 1860).

Diagnosis.—Calyx shape medium cone; basal circlet low; zero fixed secundibrachials; primibrachitaxis highest brachitaxis in vertical wall of calyx; two ranges in regular interray; regular interray in contact with tegmen; posterior interray in contact with tegmen; fixed interbrachials between half-rays present; arms strongly grouped; arm lobes present, long, and 
extend laterally; tegmen lower than or same height as calyx; plates on tegmen nodose; tegmen shape flat- to low inverted bowl; tegmen interrays not depressed; anal tube eccentric.

Occurrence.-This genus is known from the Osagean of Iowa, Missouri, New Mexico, Nevada, and Arizona.

Discussion.-The species Steganocrinus altus and S. longus may be variations of $S$. pentagonus. The descriptions by Brower (1965) indicated that the tegmen features of all three species are the same, and that it is only minor differences in the calyx that separates them. The differences between S. altus and S. pentagonus is that S. altus has a more conical dorsal cup; however, when comparing S. pentagonus (plate 92, figure 29) and S. altus (plate 93, figure 7), it is difficult to tell the two apart. Steganocrinus longus differs from S. pentagonus by having low basals, highly tumid calyx plates, and very high ambulacral tracts. Geographically, S. altus and S. longus only occur in the Nunn Member of the Lake Valley Formation, which also indicates that they may be variations of $S$. pentagonus. As the individual review of the species is beyond the scope of this paper, they will remain separate species.

Steganocrinus planus Brower, 1965 is a species that is least like the others in the genus. The main difference being that all other species of Steganocrinus have few, large plates on the tegmen, but S. planus is covered with numerous smaller plates. Brower (1965) noted that the tegmen is very similar to Abactinocrinus, but all features of the calyx better fit with Steganocrinus. Therefore, we will follow Brower and retain S. planus within this genus.

Another species Brower (1965) described is Steganocrinus burlingtonensis. He stated the following similarity between $S$. burlingtonensis and S. planus: both have flat tegmens with small tegmen plates, but with calyx features that are most similar to the genus Steganocrinus. The feature that distinguishes $S$. burlingtonensis is the lack of an anal tube on the single known 
specimen. Brower's description and illustrations indicate that the anal tube was never present, whereas S. planus exhibits evidence of an anal tube, although the tube had been broken off. The lack of an anal tube would remove S. burlingtonensis from this genus, but there is no currently known actinocrinitid genus to place it in. The two genera that do not have an anal tube also lack arm lobes, which this species has. As there is only one specimen of S. burlingtonensis, with no way of knowing what the variations of the species could be or even if it is not just an aberrant form of S. planus, a new genus will not be erected. Therefore, Steganocrinus? burlingtonensis will remain associated with this genus until more information becomes available.

Genus Strotocrinus Meek and Worthen, 1866b

Type species.-Actinocrinites perumbrosus Hall, 1860; by subsequent designation (Meek and Worthen, 1866a).

Diagnosis.-Calyx shape medium cone flared distally; basal circlet low; one fixed secundibrachial; secundibrachitaxis or tertibrachitaxis highest brachitaxis in vertical wall of calyx; 10 or more ranges in regular interray; regular interray not in contact with tegmen; posterior interray not in contact with tegmen; fixed intrabrachials between half-rays present; arms not grouped; arm lobes absent; tegmen lower than calyx; plates on tegmen smooth; tegmen shape flat inverted bowl; tegmen interrays not depressed; anal tube absent, opening eccentric.

Occurrence.- This genus is known from the Osagean of Iowa and Missouri. Discussion.-Strotocrinus glyptus (Hall, 1860), is the only recognized species in this genus. Macurda (1974) synonymized all reported members of the genus into S. glyptus, including $S$. perumbrosus; stating that $S$. glyptus is the valid name due to page priority. Ausich 
and Kammer (1991) also discussed nomenclatural history of S. glyptus and therefore, it will not be repeated here.

Genus Teleiocrinus Wachsmuth and Springer, 1881

Type species.-Actinocrinites umbrosus Hall, 1858; by original designation.

Other species.—North American species include Teleiocrinus adolescens Wachsmuth and Springer, 1897; Teleiocrinus blairi (Miller and Gurley, 1895) [new combination]; Teleiocrinus liratus (Hall, 1859); Teleiocrinus ornatus (Miller and Gurley, 1896a) [new combination]; and Teleiocrinus venustus (Miller and Gurley, 1893) [new combination]. Russian species include Teleiocrinus? sibiricus Yakovlev in Yakovlev and Ivanov, 1956. Diagnosis.—Calyx shape medium cone; basal circlet high; one fixed secundibrachial; tertibrachitaxis highest brachitaxis in vertical wall of calyx; five or more ranges in regular interray; regular interray may or may not be in contact with tegmen; posterior interray not in contact with tegmen; fixed intrabrachials between half-rays present; arms not grouped; arm lobes absent; tegmen lower than calyx; plates on tegmen nodose; tegmen shape flat cone; tegmen interrays not depressed; anal tube central.

Occurrence.-This genus occurs in the Kinderhookian of Missouri, the Osagean of Iowa, Missouri, Illinois, and New Mexico, and the Tournaisian of Russia.

Discussion.—Strotocrinus blairi and S. ornatus have been reassigned to Teleiocrinus because they have an anal tube, which Strotocrinus does not. Strotocrinus venustus is reassigned to Teleiocrinus based on characters of the calyx (the tegmen is unknown; and therefore, it is unknown whether an anal tube exists). The calyx of $T$. venustus lacks distal flaring and has fewer ranges in the interray than Strotocrinus. Macurda (1974) placed this species with 
Cusacrinus ectypus (Meek and Worthen, 1870), but the original description (Miller and Gurley, 1893, p. 27) and illustration (pl. VI, fig. 1) show that it has at least 60 arm facets that separate the calyx from the tegmen, not allowing for the interrays to be in contact with the tegmen. This feature distinguishes this species from Cusacrinus, which has fewer arms and interrays that connect with the tegmen.

Genus Thinocrinus Ausich and Sevastopulo, 2001

Type species.-Sampsonocrinus westheadi Wright, 1947, by original designation. Other species.—European species include Thinocrinus loricatus (Schlotheim, 1820); 2001; Thinocrinus smythi Ausich and Sevastopulo, 2001; and Thinocrinus wexfordensis Ausich and Sevastopulo.

North American species include Thinocrinus anchorensis (Webster and Lane, 1987) [new combination]; Thinocrinus benedicti (Miller, 1892) [new combination]; Thinocrinus blairi (Miller and Gurley, 1897) [new combination]; Thinocrinus botruosus (Miller and Gurley, 1895) [new combination]; Thinocrinus eximius (Kirk, 1943) [new combination]; Thinocrinus gibsoni (Miller and Gurley, 1893) [new combination]; Thinocrinus griffithi (Wachsmuth and Springer, 1897) [new combination]; Thinocrinus lowei (Hall, 1858) [new combination]; Thinocrinus multiradiatus (Shumard, 1857) [new combination]; Thinocrinus multiramosus altidorsatus (Rowley, 1904) [new combination]; Thinocrinus pernodosus (Hall, 1858) [new combination]; Thinocrinus probolos (Ausich and Kammer, 1991) [new combination]; Thinocrinus? sampsoni (Miller and Gurley, 1896c) [new combination]; Thinocrinus semimultiramosus (Whitfield, 1900) [new combination]; Thinocrinus scitulus (Miller and Gurley, 1897) [new combination]; Thinocrinus subpulchellus (Miller and Gurley, 1896c) [new combination]; Thinocrinus tripus 
(Ehlers and Kesling, 1963) [new combination]; and Thinocrinus verrucosus (Hall, 1858) [new combination].

Diagnosis. - Calyx shape medium cone to medium bowl; basal circlet high or low; one or two fixed secundibrachials; primibrachitaxis highest brachitaxis in vertical wall of calyx; three or four ranges in regular interray; regular interray in contact with tegmen; posterior interray in contact with tegmen; fixed intrabrachials between half-rays present or absent; arms strongly grouped; arm lobes present and extend laterally; arm lobes medium; tegmen lower than calyx; plates on tegmen nodose or smooth; tegmen shape flat to medium cone or low inverted bowl; tegmen interrays depressed; anal tube central.

Occurrence.-This genus occurs in the Osagean of Kentucky, Indiana, Missouri, Illinois, Iowa, and Nevada, as well as the Tournaisian of Scotland, Ireland, and England.

Discussion.-Most of the species reassignments to Thinocrinus are due to the redefinition of Actinocrinites (Ausich and Sevastopulo, 2001). Therefore, many of the species assigned to Thinocrinus were formerly in Actinocrinites. The exception is reassignment of Physetocrinus sampsoni to Thinocrinus.

The calyx characters of Thinocrinus? sampsoni [new comb.] are three ranges in the regular interray, fixed intrabrachials between the half-rays absent, and arm lobes present. Physetocrinus has more ranges in the regular interrays, fixed interbrachials between half-rays, and the arms do not form lobes. The features that makes it similar to Physetocrinus is the lack of an anal tube on the tegmen. Only two genera of actinocrinitids are known to lack an anal tube (Physetocrinus and Strotocrinus), but the other features of the species do not fit either of those genera. In some ways, Thinocrinus? sampsoni is similar to Steganocrinus? burlingtonensis in that both have arm lobes and lack an anal tube. However, they lack other similarities. The calyx 
shape, basal height, and interray ranges are all very different and it would not make sense to combine these into a single, new genus. Until more information can be found on this species, Thinocrinus? sampsoni will remain with this genus.

There is some confusion with the species Actinocrinites scitulus. Kirk (1943) said there is some question as to whether or not Actinocrinites sharonensis (Miller and Gurley, 1897) is a valid species, but listed it as being synonymous with $A$. scitulus. Brower (1955) stated that $A$. sharonensis should be a separate species, but listed A. scitulus in the synonymy list. On the same page, Brower listed A. scitulus as a separate species. Webster (2003) followed Brower’s first synonymy list, naming A. sharonensis as the valid name in the index and A. scitulus as a junior synonym. It is the belief of the authors that both species are the same, just variations. Because A. scitulus has priority, the valid name for this species is Thinocrinus scitulus [new comb.]. Webster (2003) left Steganocrinus griffithi Miller and Gurley, 1897 as a separate species, even though Kirk, (1943) and Brower (1955) synonymized it with Actinocrinites scitulus. 


\section{REFERENCES}

Ausich, W. I., C. E. Brett, H. Hess, and M. J. Simms. 1999. Crinoid form and function, p. 3-30. In H. Hess, W. I. Ausich, C. E. Brett, and M. J. Simms, Fossil Crinoids. Cambridge University Press, Cambridge.

Ausich, W. I., And T. W. Kammer. 1991. Systematic revision of Aorocrinus, Dorycrinus, Macrocrinus, Paradichocrinus, Strotocrinus, and Uperocrinus: Mississippian camerate crinoids (Echinodermata) from the stratotype region. Journal of Paleontology, 65:936-944.

Ausich, W. I. And T. W. Kammer. 2006. Stratigraphical and geographical distribution of Mississippian (Lower Carboniferous) Crinoidea from England and Wales. Proceedings of the Yorkshire Geological Society, 56(1):91-109.

Ausich, W. I. And T. W. Kammer. 2008. Generic concepts in the Amphoracrinidae Bather, 1899 (Class Crinoidea) and evaluation of generic assignments of North American species. Journal of Paleontology, 82:1139-1149.

Ausich, W. I. and T. W. Kammer. 2009. Generic concepts in the Platycrinitidae Austin and Austin, 1842 (Class Crinoidea). Journal of Paleontology, 83:694-717.

Ausich, W. I. And T. W. Kammer. 2010. Generic concepts in the Batocrinidae Wachsmuth and Springer, 1881 (Class Crinoidea). Journal of Paleontology, 84:32-50.

Ausich, W. I. and G. D. Sevastopulo. 2001. The Lower Carboniferous (Tournaisian) crinoids from Hook Head, County Wexford, Ireland. Monograph of the Palaeontological Society 617, $136 \mathrm{p}$.

Austin, T., SR. And T. Austin, JR. 1842. XVIII. - Proposed arrangement of the Echinodermata, particularly as regards the Crinoidea, and a subdivision of the Class Adelostella (Echinidae). Annals and Magazine of Natural History, series 1, 10:106-113.

Austin, T., SR. And T. Austin, JR. 1843-1847. A monograph on recent and fossil Crinoidea, with figures and descriptions of some Recent and fossil allied genera. 1(2):1-32 (1843); 1(3):3348 (1844); 1(4):49-64 (1845); 1(5):65-80 (1846); 1(6-8):81-128 (1847). London and Bristol.

Bassler, R. S. and M. W. Moodey. 1943. Bibliographic and faunal index of Paleozoic pelmatozoan echinoderms. Geological Society of America Special Paper 45, 734 p.

Bowsher, A. L. 1955. New genera of Mississippian camerate crinoids. Echinodermata Article 1, University of Kansas Paleontological Contributions, 23p.

Bowsher, A. L. and G. Ubaghs 1978. Family Actinocrinitidae, T452-T462. In R. C. Moore and K. Teichert (eds.), Treatise on Invertebrate Paleontology, Echinodermata, Pt. T(2). Geological Society of America and University of Kansas Press, Boulder and Lawerence. 
Bronn, H. G. 1849. Index palaeontologicus, unter Mitwirking der Herren Prof. H. R. Göppert und H. von Meyer. Handbuch einer Geschichte der Nature, 5, Abt. 1, A. Nomenclator Palaeontologicus, $1381 \mathrm{p}$.

Brower, J. C. 1965. The genus, Steganocrinus. Journal of Paleontology, 39:773-793.

Brower, J. C. 1967. The actinocrinitid genera Abactinocrinus, Aacocrinus and Blairocrinus. Journal of Paleontology, 41:675-705.

Brower, J. C. 1978. Camerates, p. T244-T263. In R. C. Moore and K. Teichert (eds.), Treatise on Invertebrate Paleontology, Echinodermata, Pt. T(1). Geological Society of America and University of Kansas Press, Boulder and Lawerence.

CampBell, K.S.W., And J. Bein. 1971. Some lower Carboniferous crinoids from New South Wales. Journal of Paleontology, 45:419-436.

Collignon, M. M., 1924, Sur un Actinocrinide de la collection Marcou au Museum National d 'Histoire Naturelle. Bulletin de la Société Géologique de France, 24:13-15.

Dun, W. S., And W. N. Benson. 1920. The geology and petrology of the Great Serpentine Belt of New South wales. Part IX--The geology, palaeontology and petrography of the Currabubula district, wtih notes on adjacent regions. Section B-Paleontology: Proceedings of the Linnean Society of New South Wales, 45:337-374.

Ehlers, G. M. and R. V. Kesling. 1963. Two new crinoids from Lower Mississippian rocks in southeastern Kentucky. Journal of Paleontology, 37:1028-1041.

Gilbertson, W. 1843. In J. E. Portlock, Report on the geology of the county of Londonderry and of parts of Tyrone and Fermanagh: Dublin, A. Miliken, 784 p.

Goldfuss, G. A. 1826-44. Petrefacta Germaniae, tam ea, Quae in Museo Universitatis Regiae Borussicae Fridericiae Wilhelmiae Rhenanea, serventur, quam alia quaecunque in Museis Hoeninghusiano Muensteriano aliisque, extant, iconibus et descriiptionns illustrata. -Abbildungen und Beschreibungen der Petrefacten Deutschlands und der Angränzende Länder, unter Mitwirkung des Hern Grafen Georg zu Münster, herausgegeben von August Goldfuss. v. 1 (1826-1833), Divisio prima. Zoophytorum reliquiae, p. 1-114; Divisio secunda. Radiariorum reliquiae, p. 115-221 [Echinodermata]; Divisio tertia. Annulatorium reliquiae, p. 222-242; v. 2 (1834-40), Divisio quarta. Molluscorum acephalicorum reliquiae. I. Bivalvia, p. 65-286; II. Brachiopoda, p. 287-303; III. (1841-44), Divisio quinta. Molluscorum gasteropodum reliquiae, p. 1-121; atlas of plates, 1-199, Düsseldorf, Arnz \& Co. v. 1, p. 1-76 (1826); p. 77-164 (1829); p. 165-240 (1831); p. 241-252 (1833); v. 2, p. 168 (1833); p. $69-140$ (1836); p. 141-224 (1837); p. 225-312 (1840); v. 3, p. 1-128 (1844).

HaLl, J. 1858. Chapter 8. Palaeontology of Iowa, p. 473-724. In J. Hall and J. D. Whitney, Report of the Geological Survey of the state of Iowa: Embracing the results of investigations 
made during portions of the years 1855, 56 \&: 57, v. 1, part II; Palaeontology, p. 473-724, 29 pl., index to Part II separately paginated, 3 p.

HaLl, J. 1859. Contributions to the palaeontology of Iowa, being descriptions of new species of Crinoidea and other fossils. Supplement to vol. I, part II, of the Geological Report of Iowa, 92p.

Hall, J. 1860. Contributions to the palaeontology of Iowa: being descriptions of new species of Crinoidea and other fossils. Iowa Geologyical Survey, 1(2) supplement, 94 p.

Hall, J. 1861a. Descriptions of new species of Crinoidea from the Carboniferous rocks of the Mississippi Valley. Journal of the Boston Society of Natural History, 3:261-328.

Hall, J. 1861b. Descriptions of new species of crinoidea; from investigations of the Iowa Geological Survey, Preliminary notice. C. van Benthuysen, Albany, New York, 18 p.

Hall, J. 1863. Preliminary notice, of some species of Crinoidea from the Waverly Sandstone series of Summit Co., Ohio, supposed to be of the age of the Chemung Group of New York: Preprint of Seventeenth Annual Report of the Regents of the University of the state of New-York, on the Condition of the State Cabinet of Natural History, and the Historical and Antiquarian Collection annexed thereto, State of New York in Senate Document 189, Albany, Comstock and Cassiday Printers, p. 50-60.

Heckel, P. and G. Clayton. 2005. Official names of the Carboniferous System. Geology Today, 21(6):213-214.

Kammer, T. W. And W. I. Ausich. 2006. The “Age of Crinoids” a Mississippian biodiversity spike coincident with widespread carbonate ramps. Palaios, 21:238-248.

Keyes, C. R. 1894. Paleontology of Missouri, Pt. I. Missouri Geological Survey, 4:143-225.

KIRK, E. 1943. A revision of the genus Steganocrinus. Journal of the Washington Academy of Science, 33:259-265.

KIRK, E. 1944. Cytidocrinus, a new name for Cyrtocrinus Kirk. Journal of the Washington Academy of Science, 34:85.

Koninck, L. G. De and H. Le Hon. 1854. Recherches sur les crinoides du terrain carbonifere de la Belgiqu. Academie Royal de Belgique, Memoir, 28(3), 215p.

Lane, N. G., J. A. Waters, and C. G. Maples. 1997. Echinoderm faunas of the Hongguleleng Formation, Late Devonian (Famennian), Xinjiang-Uygur Autonomous Region, People’s Republic of China: Journal of Paleontology, 71 Memoir (Supplement to no. 2):1-43.

Laudon, L. R. 1933. The stratigraphy and paleontology of the Gilmore City Formation of Iowa. University of Iowa Studies, 15(2):1-74. 
Laudon, L. R., J. M. Parks, And A. C. Spreng. 1952. Mississippian crinoid fauna from the Banff Formation Sunwapta Pass, Alberta. Journal of Paleontology, 26:544-575.

Laudon, L. R., and J. L. Severson. 1953. New crinoid fauna, Mississippian, Lodgepole Formation, Montana. Journal of Paleontology, 27:505-536.

Lee, K., W. I. Ausich, and T. W. Kammer. 2005. Crinoids from the Nada Member of the Borden Formation (Lower Mississippian) in eastern Kentucky. Journal of Paleontology, 79:337-355.

LindLEy, I. D. 1979. An occurrence of the camerate crinoid genus Eumorphocrinus in the Early Carboniferous of New South Wales. Journal and Proceedings of the Royal Society of New South Wales, 112( 3-4):121-124.

Lindley, I. D. 1988. Glaphyrocrinus, a new camerate crinoid genus from the Lower Carboniferous of New South Wales. Alcheringa, 12:129-136.

Macurda, D. B., Jr. 1974. A quantitative phyletic study of the camerate crinoid Families Actinocrinitidae and Periechocrinitidae and its taxonomic implications. Journal of Paleontology, 48:820-832.

Matthews, S. C. 1973. Notes on open nomenclature and on synonymy lists. Palaeontology, 16(4):713-719.

McChesney, J. H. 1861. Descriptions of new fossils from the Paleozoic rocks of the western states. Transactions of the Chicago Academy of Science, 2:77-95.

M'coy, F. 1844. In Griffith, R., A synopsis of the characters of the Carboniferous limestone fossils of Ireland: Dublin, University Press, 274 p.

Meek, F. B. And A. H. Worthen. 1860. Descriptions of new species of crinoidea and echinoidea from the Carboniferous rocks of Illinois, and other western states. Proceedings of the Academy of Natural Sciences of Philadelphia, 12:379-397.

Meek, F. B. And A. H. Worthen. 1866a. Descriptions of invertebrates from the Carboniferous system. Illinois Geological Survey, 2(2):143-411.

Meek, F. B. And A. H. Worthen. 1866b. Contributions to the palaeontology of Illinois and other western states. Proceedings of the Academy of Natural Sciences of Philadelphia (1865), 17:251-274.

Meek, F. B. And A. H. Worthen. 1869. Descriptions of new Carboniferous fossils from the western States. Proceedings of the Academy of Natural Sciences of Philadelphia, 22:137172. 
Meek, F. B. and A. H. Worthen. 1870. Descriptions of new Carboniferous fossils from the western States. Proceedings of the Academy of Natural Sciences of Philadelphia, 21:137172.

Miller, J. S. 1821. A natural history of the Crinoidea, or lily-shaped animals; with observations on the genera, Asteria, Euryale, Comatula and Marsupites. Bryan \& Co., Bristol, England, $150 \mathrm{p}$.

Miller, S. A. 1881. Subcarboniferous fossils from the Lake Valley Mining District of New Mexico, with descriptions of new species. Journal of the Cincinnati Society of Natural History, 4(4):306-315.

Miller, S. A. 1889. North American geology and paleontology. Western Methodist Book Concern, Cincinnati, 664 p.

Miller, S. A. 1891b. Palaeontology. Advance sheets. Indiana Department of Geology and Natural Resources, 17th Annual Report, 103 p.

Miller, S. A. 1892a. North American geology and paleontology, first appendix. Cincinnati, Western Methodist Book Concern, p. 665-718.

Miller, S. A. And W. F. E. Gurley. 1893. Description of some new species of invertebrates from the Palaeozoic rocks of Illinois and adjacent states. Illinois State Museum Bulletin 3, 81 p.

Miller, S. A. And W. F. E. Gurley. 1894. New genera and species of Echinodermata. Illinois State Museum Bulletin 5, 53 p.

Miller, S. A. And W. F. E. Gurley. 1895b. New and interesting species of Palaeozoic fossils. Illinois State Museum Bulletin 7, 89 p.

Miller, S. A. And W. F. E. Gurley. 1896a. Description of new and remarkable fossils from the Palaeozoic rocks of the Mississippi Valley. Illinois State Museum Bulletin 8, 65 p.

Miller, S. A. And W. F. E. Gurley. 1896b. New species of Crinoids from Illinois and other states. Illinois State Museum Bulletin 9, 66 p.

Miller, S. A. And W. F. E. Gurley. 1896c. New species of Echinodermata and a new crustacean from the Palaeozoic rocks. Illinois State Museum Bulletin 10, 91 p.

Miller, S. A., And W. F. E. Gurley. 1897. New species of crinoids, cephalopods, and other Palaeozoic fossils. Illinois State Museum Bulletin 12, 69 p.

Minato, M. 1951. On the Lower Carboniferous fossils of the Kitakami Massif, NE Honsyu, Japan. Journal of the Faculty of Science, Hokkaido University, 7:355-382 
Moore, R. C. And L.R. Laudon. 1943. Evolution and classification of Paleozoic crinoids. Geological Society of America Special Paper 46, 151p.

Moore, R. C. and C. Teichert, eds. 1978. Treatise on Invertebrate Paleontology, Part T, Echinodermata 2, Crinoidea: 3 vols., Geological Society of America and University of Kansas, 1026 p.

Morris, J. 1843. A catalogue of British fossils. Comprising all the genera and species hitherto described; with reference to their geological distribution and to the localities in which they have been found, 1st ed. London, John Van Voorst, 222 p.

Owen, D. D. and B. F. Shumard. 1852. Descriptions of seven new species of crinoidea from the subcarboniferous of Iowa and Illinois. Journal of the Academy of Natural Sciences of Philadelphia, series 2, 2:89-94.

Peck, R. E. And I. A. Keyte. 1938. The Crinoidea of the Chouteau Limestone. In E. B. Branson (ed), Stratigraphy and paleontology of the Lower Mississippian of Missouri, Pt. 2: Missouri University Studies, 13(4):70-108.

Phillips, J. 1836. Illustrations of the geology of Yorkshire, or a description of the strata and organic remains. Pt. 2, The Mountain Limestone districts, 2nd edit. London, John Murray, p. 203-208.

Phillips, J., 1841. Figures and descriptions of the Palaeozoic fossils of Cornwall, Devon, and West Somerset; observed in the course of the ordinance geological survey of that district: London, Longmans, Brown, Green, and Longmans, 232 p. , 60 pl. (Crinoidea, p. 28-32, pl. 15-16)

PortLock, J. E. 1843. Report on the geology of the County of Londonderry and of parts of Tyrone and Fermanagh: Dublin, A. Milliken, 784 p.

Rhenberg, E. C. And T. W. Kammer. (in prep). Camerate crinoids of the Lower Mississippian Lake Valley Formation (Nunn Member, Osagean), New Mexico. [intended for Journal of Paleontology].

Rowley, R. R. 1900. New species of crinoids, blastoids and cystoids from Missouri. American Geologist, 25:65-75.

Rowley, R. R.. 1901-04. Description of fossils. In Green, G. K., Contribution to Indiana Palaeontology: New Albany, Indiana, v. 1, no. 7, p. 50-60, pl. 19-21 (1901a); no. 8, p. 62-74, pl. 22-24 (1901b); no. 10, p. 85-97, pl. 28-30 (1902a); no. 11, p. 98-109, pl. 31-33 (1903a); no. 12 , p. $110-129$, pl. 34-36 (1903b); no. 13, p. 130-137, pl. $37-39$ (1903c); no. 14, p. 138145, pl. 40-42 (1903d); no. 15, p. 146-155, pl. 43-45 (1903e); no. 16, p. 156-167, pl. 46-48 (1903f); no. 17, p. 168-175, pl. 49-51 (1904a); no. 18, p. 176-184, pl. 52-54 (1904b); no. 19, p. 185-197, pl. 55-57 (1904c). 
Rowley, R. R. and S. J. Hare. 1891. Description of some new species of Echinodermata from the sub-Carboniferous rocks of Pike County, Mo. Kansas City Scientist, 5(7):97-103.

Sallan, L. C., T. W. Kammer, W. I. Ausich, and L. A. CooK. 2011. Persistent predator-prey dynamics revealed by mass extinction. Proceedings of the National Academy of Science, 108:8335-8338.

Schlotheim, E. F. von. 1820. Die Petrefactenkunde auf ihrem jetzigen Standpunkte durch die Beschreibung seiner Sammlung versteinerter und fossiler Überreste des Thier-und Pflanzenreichs der Vorwelt erläutert. Gotha, Beckersche Buchhandlung, 437 p.

Sснмітт, W. E. 1930. Die Echinodermen des deutschen Unterkarbons. Abhandlungen der Preussichen Geologischen Landesanstalt, n. s., 122(1):1-92.

Shumard, B. F. 1855. Description of new species of organic remains. Missouri Geological Survey, 2:185-208.

Shumard, B. F. 1857. Description of new fossil Crinoidea from the Palaeozoic rocks of the western and southern portions of the United States. Transactions of the St. Louis Academy of Science. 1:71-80.

Solov'Yeva, M. V. 1984. Novyi rod krinoidei kamerat iz Karbona Urala [A new genus of camerate crinoid from the Carboniferous of the Urals]. Paleontologicheskii Zhurnal, 4:114118.

Swofford, D. L. 2001. PAUP*: Phylogenetic Analysis Using Parsimony, version 4.0b10. Computer program distributed by Sinauer Associates, Inc., Sunderland, MA (http://www.paup.csit.fsu.edu).

Termier, G., And H. Termier. 1950. Paléontologie Marocaine II. Invertébres de l'Ere Primaire. 4. Annélides, Arthropodes, Echinodermes, Conularides et Graptolithes. Service Carte Géologique Morocco, Notes et Mémoires, 79(4):1-279.

Ubaghs G. 1978a. Skeletal Morphology of Fossil Crinoids, p. T59-T216. In R. C. Moore and K. Teichert (eds.), Treatise on Invertebrate Paleontology, Echinodermata, Pt. T(1). Geological Society of America and University of Kansas Press, Boulder and Lawerence.

Ubaghs G. 1978b. Camerata, p. T408-T519. In R. C. Moore and K. Teichert (eds.), Treatise on Invertebrate Paleontology, Echinodermata, Pt. T(2). Geological Society of America and University of Kansas Press, Boulder and Lawerence.

Ubaghs G. 1978c. Subfamily Eumorphocrininae, p. T456-T458. In R. C. Moore and K. Teichert (eds.), Treatise on Invertebrate Paleontology, Echinodermata, Pt. T(2). Geological Society of America and University of Kansas Press, Boulder and Lawerence. 
Ubaghs G. 1978d. Subfamily Cactocrininae, p. T458-T460. In R. C. Moore and K. Teichert (eds.), Treatise on Invertebrate Paleontology, Echinodermata, Pt. T(2). Geological Society of America and University of Kansas Press, Boulder and Lawerence.

Ubaghs G. 1978e. Subfamily Physetocrininae, p. T460-T462. In R. C. Moore and K. Teichert (eds.), Treatise on Invertebrate Paleontology, Echinodermata, Pt. T(2). Geological Society of America and University of Kansas Press, Boulder and Lawerence.

Van SAnt, J. F. 1965. Actinocrinites grandissimus, a new name for a camerate crinoid from Borden (lower-Middle Mississippian) rocks of Indiana. Journal of Paleontology, 39: 290292.

Wachsmuth, C. and F. Springer. 1880-1886. Revision of the Palaeocrinoidea. Proceedings of the Academy of Natural Sciences of Philadelphia Pt. I. The families Ichthyocrinidae and Cyathocrinidae (1880):226-378, (separate repaged p. 1-153); Pt. II. Family Sphaeroidocrinidae, with the sub-families Platycrinidae, Rhodocrinidae, and Actinocrinidae (1881):177-411 (separate repaged, p. 1-237); Pt. III, Sec. 1. Discussion of the classification and relations of the brachiate crinoids, and conclusion of the generic descriptions (1885):225364 (separate repaged, p. 1-138); Pt. III, Sec. 2. Discussion of the classification and relations of the brachiate crinoids, and conclusion of the generic descriptions (1886):64-226 (separate repaged to continue with section $1,139-302)$.

Wachsmuth, C. and F. Springer. 1897. The North American Crinoidea Camerata. Harvard College Museum of Comparative Zoology Memoirs, 20 and 21, 897 p.

Wanner, J. 1924. Die permischen Krinoiden von Timor. Jaarbook van net Mijnwezen Nederlandes Oost-Indie, Verhandlungen (1921), Gedeelte, 3:1-348.

Wanner, J. 1937. Neue beiträge zur kenntnis der Permischen echinodermen von Timor, VIIIXIII. Palaeontographica, Supplement 4, IV Abteilungen, Abschnitt 1, p. 1-212.

Waters, J. A., C. G. Maples, N. G. Lane, S. Marcus, Z-T. Liao, L. Liu, H-F. Hou, and J-X. WANG. 2003. A quadrupling of Famennian pelmatozoan diversity: new Late Devonian blastoids and crinoids from northwest China. Journal of Paleontology, 77(5):922-948.

Webster, G. D. 2003. Bibliography and index of Paleozoic crinoids, coronates, and hemistreptocrinoids 1758-1999. Geological Society of America Special Paper 363.

Webster, G. D. And P. A. Jell. 1999. New Carboniferous crinoids from eastern Australia. Memoirs of the Queensland Museum, 43(1):237-278.

Webster, G. D. and N. G. Lane. 1987. Crinoids from the Anchor Limestone (Lower Mississippian) of the Monte Cristo Group Southern Nevada. University of Kansas Paleontological Contributions Paper, 119, 55 p. 
Webster, G. D., C. G. Maples, G. D. Sevastopulo, T. J. Frest, and J. A. Waters. 2004. Carboniferous (Visean-Moscovian) echinoderm faunas from the Bechar Basin area of western Algeria. Bulletin of American Paleontology 368, 98 p.

Weller, S. 1909. Kinderhook faunal studies - V, the fauna of the Fern Glen Formation. Geological Society of America, Bulletin, 20:265-332.

Whidborne, G. F. 1896. A preliminary synopsis of the faunas of the Pickwell Down, Baggy, and Pilton Beds. Proceedings of the Geological Association, 14:371-377.

White, C. A. 1874. Preliminary report upon invertebrate fossils collected by the expeditions of 1871, 1872, and 1873. Geographical and Geological Exploration and Surveys west of the 100th Meridian, Washington, D.C., Government Printing Office, p. 1-27.

Whitfield, R. P. 1900. Description of a new crinoid from Indiana. American Museum of Natural History, Bulletin, 13: 23-24.

Wood, E. 1914. The use of crinoid arms in studies of phylogeny. Annals of the N.Y. Academy of Science, 24:1-17.

Wright, J. 1947. Steganocrinus westheadi n. sp. and note on a rare crinoid and a blastoid from the Carboniferous Limestone of Coplow Knoll, Clitheroe. Geological Magazine, 84:101-105.

Wright, J. 1950-1960. The British Carboniferous Crinoidea. Palaeontographical Society, Monograph, 1(1):1-24, 1950; 1(2):25-46, 1951a; 1(3):47-102, 1951b; 1(4:103-148, 1952a; 1(5):149-190,1954a; 2(1):191-254, 1955a; 2(2):255-272, 1955b; 2(3):273-306, 1956b; 2(4):307-328,1958; 2(5):329-347 1960.

Yakovlev, N. N. AND A. P. Ivanov. 1956. Morskie lilii i blastoidei kamennougolnykh i permskikh otlozhenii SSSR [Marine crinoids and blastoids of the Carboniferous and Permian deposits of Russia]. Vsesoyuznogo Nauchno-Issledovatelskii Geologicheskogo Institut Trudy, 11:1-142. 
TABLE 2.1.-Listing of actinocrinitid species that have a revised generic assignment.

NEW GENERIC ASSIGNMENTS

Previous assignment

Actinocrinites anchorensis Webster and Lane, 1987

Actinocrinites benedicti (Miller, 1892)

Actinocrinites blairi (Miller and Gurley, 1897)

Actinocrinites botruosus (Miller and Gurley, 1895)

Actinocrinites erraticus (Miller and Gurley, 1893)

Actinocrinites eximius (Kirk, 1943)

Actinocrinites gibsoni (Miller and Gurley, 1893)

Actinocrinites griffithi (Wachsmuth and Springer, 1897)

Actinocrinites lowei (Hall, 1858)

Actinocrinites multiradiatus (Shumard, 1857)

Actinocrinites multiramosus altidorsatus (Rowley, 1904)

Actinocrinites pernodosus (Hall, 1858)

Actinocrinites plagosus (Miller and Gurley, 1893)

Actinocrinites probolos Ausich and Kammer, 1991

Actinocrinites scitulus (Miller and Gurley, 1897)

Actinocrinites semimultiramosus (Whitfield, 1900)

Actinocrinites sobrinus (Miller and Gurley, 1896c)

Actinocrinites spectabilis (Miller and Gurley, 1896c)

Actinocrinites subpulchellus (Miller and Gurley, 1896c)

Actinocrinites subscitulus (Miller and Gurley, 1896c)

Actinocrinites tripus Ehlers and Kesling, 1963

Actinocrinites verrucosus (Hall, 1858)

Cactocrinus reticulatus (Hall, 1861)

Cactocrinus reticulatus ovatus (Hall, 1861)

Cusacrinus bischoffi (Miller and Gurley, 1896c)

Cusacrinus gracilis (Wachsmuth and Springer, 1897)

Cusacrinus hurdianus (McChesney, 1861)

Cusacrinus imperator (Laudon, 1933)

Eumorphocrinus sp. Brower, 1970

Nunnacrinus sampsoni (Miller and Gurley, 1896c)

Physetocrinus sampsoni Miller and Gurley, 1896c

Physetocrinus smalleyi Weller, 1909

Strotocrinus blairi Miller and Gurley, 1895

Strotocrinus ornatus Miller and Gurley, 1896a

Strotocrinus venustus Miller and Gurley, 1893
Current assignment

Thinocrinus anchorensis (Webster and Lane, 1987)

Thinocrinus benedicti (Miller, 1892)

Thinocrinus blairi (Miller and Gurley, 1897)

Thinocrinus botruosus (Miller and Gurley, 1895)

Nunnacrinus erraticus (Miller and Gurley, 1893)

Thinocrinus eximius (Kirk, 1943)

Thinocrinus gibsoni (Miller and Gurley, 1893)

Thinocrinus griffithi (Wachsmuth and Springer, 1897)

Thinocrinus lowei (Hall, 1858)

Thinocrinus multiradiatus (Shumard, 1857)

Thinocrinus multiramosus altidorsatus (Rowley, 1904)

Thinocrinus pernodosus (Hall, 1858)

Nunnacrinus plagosus (Miller and Gurley, 1893)

Thinocrinus probolos (Ausich and Kammer, 1991)

Thinocrinus scitulus (Miller and Gurley, 1897)

Thinocrinus semimultiramosus (Whitfield, 1900)

Cusacrinus sobrinus (Miller and Gurley, 1896c)

Cusacrinus spectabilis (Miller and Gurley, 1896c)

Thinocrinus subpulchellus (Miller and Gurley, 1896c)

Cusacrinus subscitulus (Miller and Gurley, 1896c)

Thinocrinus tripus (Ehlers and Kesling, 1963)

Thinocrinus verrucosus (Hall, 1858)

Nunnacrinus reticulatus (Hall, 1861)

Nunnacrinus ovatus (Hall, 1861)

Cactocrinus bischoffi (Miller and Gurley, 1896c)

Dialutocrinus gracilis (Wachsmuth and Springer, 1897)

Cactocrinus hurdianus(McChesney, 1861)

Cacotcrinus imperator (Laudon, 1933)

Actinocrinites sp. (Brower, 1970)

Cusacrinus sampsoni (Miller and Gurley, 1896c)

"Thinocrinus" sampsoni (Miller and Gurley, 1896c)

Blairocrinus smalleyi (Weller, 1909)

Teleiocrinus blairi (Miller and Gurley, 1895)

Teleiocrinus ornatus (Miller and Gurley, 1896a)

Teleiocrinus venustus (Miller and Gurley, 1893) 
TABLE 2.2.-Chronostratigraphic correlation of time units for North America and Europe (from Ausich and Kammer, 2008).

\begin{tabular}{cll}
\hline \hline $\begin{array}{c}\text { Time } \\
\text { Units }\end{array}$ & \multicolumn{1}{c}{$\begin{array}{c}\text { North American } \\
\text { chronostratigraphic units }\end{array}$} & European chronostratigraphic units \\
\hline 11 & Upper Chesterian & Arnsbergian (E2) \\
10 & Middle Chesterian & Serpukhovian, Pendleian (E1) \\
9 & Lower Chesterian & Visean, Brigantian (V3c) \\
8 & Late Meramecian & Visean, Asbian (V3b) \\
7 & Early Meramecian & Visean, Holkerian (V3a) \\
6 & Late Osagean & Visean, Arundian (V1b, V2a) \\
5 & Late Osagean & Visean, upper Chadian (V1a) \\
4 & Middle Osagean & Tournaisian, lower Chadian (Tn3c) \\
3 & Early Osagean & Tournaisian, Ivorian (Tn3a-Tn3c) \\
2 & Late Kinderhookian & Tournaisian, late Hasterian (Tn2) \\
1 & Early Kinderhookian & Tournaisian, early Hasterian (Tn1b) \\
\hline
\end{tabular}


TABLE 2.3.-Diagnostic characters of the calyx and tegmen of genera within Actinocrinitidae.

\begin{tabular}{|c|c|c|c|c|c|c|c|c|c|}
\hline Genus & $\begin{array}{l}\text { Calyx } \\
\text { Shape }\end{array}$ & $\begin{array}{c}\text { Basal } \\
\text { Circlet }\end{array}$ & $\begin{array}{l}\text { Number of } \\
\text { Fixed } \\
\text { Secundibr } \\
\text { achails }\end{array}$ & $\begin{array}{c}\text { Highest Brachial in } \\
\text { Vertical Wall of } \\
\text { Calyx Before Arm } \\
\text { Lobes }\end{array}$ & $\begin{array}{c}\text { Number } \\
\text { of Ranges } \\
\text { in } \\
\text { Regular } \\
\text { Interray }\end{array}$ & $\begin{array}{l}\text { Regular } \\
\text { Interrays in } \\
\text { Contact with } \\
\text { Tegmen }\end{array}$ & $\begin{array}{c}\text { Posterior } \\
\text { Interray in } \\
\text { Contact with } \\
\text { Tegmen }\end{array}$ & $\begin{array}{c}\text { Fixed } \\
\text { Intrabrachs } \\
\text { Between Half- } \\
\text { Rays }\end{array}$ & Arms Grouped \\
\hline Cactocrinus & $\begin{array}{l}\text { medium } \\
\text { cone }\end{array}$ & low & 1 & Secundabrachitaxis & 2,3 & no & no & present & not grouped \\
\hline Ilmocrinus & $\begin{array}{l}\text { medium } \\
\text { bowl, low } \\
\text { bowl }\end{array}$ & low & 1 & Tertibrachitaxis & 2 & no & no & present & not grouped \\
\hline Teleiocrinus & $\begin{array}{l}\text { medium } \\
\text { cone }\end{array}$ & high & 1 & Tertibrachitaxis & 5 or more & yes, no & no & present & not grouped \\
\hline Strotocrinus & $\begin{array}{l}\text { medium } \\
\text { cone flared } \\
\text { distally }\end{array}$ & high & 1 & $\begin{array}{l}\text { Secundabrachitaxis, } \\
\text { Tertibrachitaxis }\end{array}$ & 10 or more & no & no & present & not grouped \\
\hline Maligneocrinus & $\begin{array}{l}\text { medium } \\
\text { globe }\end{array}$ & low & 1 & Tertibrachitaxis & 5 or more & yes & yes & present & weakly \\
\hline Cusacrinus & $\begin{array}{l}\text { medium } \\
\text { cone, low } \\
\text { cone }\end{array}$ & low, high & 1 & Secundabrachitaxis & 4 & yes & yes & present & weakly \\
\hline Nunnacrinus & $\begin{array}{l}\text { medium } \\
\text { cone, low } \\
\text { cone }\end{array}$ & low & 1 & Primibrachitaxis & 4 & yes & yes & present & weakly \\
\hline Glaphyrocrinus & $\begin{array}{l}\text { medium } \\
\text { cone }\end{array}$ & high & 2 & Secundabrachitaxis & 4 & yes & yes & present & strongly \\
\hline Manillacrinus & $\begin{array}{l}\text { medium } \\
\text { cone } \\
\text { medium }\end{array}$ & high & 1 & Secundabrachitaxis & 3 & yes & yes & present & strongly \\
\hline Thinocrinus & $\begin{array}{l}\text { cone, } \\
\text { medium } \\
\text { bowl }\end{array}$ & low, high & 1,2 & Primibrachitaxis & 3,4 & yes & yes & present, absent & strongly \\
\hline Abactinocrinus & $\begin{array}{l}\text { medium } \\
\text { bowl }\end{array}$ & low & 1 & Primibrachitaxis & 3 & yes & yes & absent & strongly \\
\hline Iotacrinus & low bowl & low & 1 & Primibrachitaxis & 3 & yes & yes & absent & strongly \\
\hline
\end{tabular}




\begin{tabular}{|c|c|c|c|c|c|c|c|c|c|}
\hline Genus & $\begin{array}{l}\text { Calyx } \\
\text { Shape }\end{array}$ & $\begin{array}{l}\text { Basal } \\
\text { Circlet }\end{array}$ & $\begin{array}{l}\text { Number of } \\
\text { Fixed } \\
\text { Secundibr } \\
\text { achails }\end{array}$ & $\begin{array}{c}\text { Highest Brachial in } \\
\text { Vertical Wall of } \\
\text { Calyx Before Arm } \\
\text { Lobes }\end{array}$ & $\begin{array}{c}\text { Number } \\
\text { of Ranges } \\
\text { in } \\
\text { Regular } \\
\text { Interray }\end{array}$ & $\begin{array}{l}\text { Regular } \\
\text { Interrays in } \\
\text { Contact with } \\
\text { Tegmen }\end{array}$ & $\begin{array}{c}\text { Posterior } \\
\text { Interray in } \\
\text { Contact with } \\
\text { Tegmen }\end{array}$ & $\begin{array}{c}\text { Fixed } \\
\text { Intrabrachs } \\
\text { Between Half- } \\
\text { Rays } \\
\end{array}$ & Arms Grouped \\
\hline Aacocrinus & $\begin{array}{l}\text { medium } \\
\text { cone, } \\
\text { medium } \\
\text { bowl }\end{array}$ & low & $0,1,2$ & $\begin{array}{l}\text { Primibrachitaxis, } \\
\text { Secundabrachitaxis }\end{array}$ & 3 & yes & yes & absent & strongly \\
\hline Blairocrinus & low cone & low & 1 & Primibrachitaxis & 2 & yes & yes & absent & strongly \\
\hline Sampsonocrinus & $\begin{array}{l}\text { medium } \\
\text { bowl }\end{array}$ & low & unknown & Primibrachitaxis & 2 & yes & yes & present & strongly \\
\hline Steganocrinus & $\begin{array}{l}\text { medium } \\
\text { cone }\end{array}$ & low & 0 & Primibrachitaxis & 2 & yes & yes & present & strongly \\
\hline Actinocrinites & $\begin{array}{l}\text { medium } \\
\text { cone, high } \\
\text { bowl }\end{array}$ & high & 1 & $\begin{array}{c}\text { Secundabrachitaxis, } \\
\text { Tertibrachitaxis, } \\
\text { Quartibrachitaxis }\end{array}$ & 3 & yes & yes & present, absent & strongly \\
\hline Dialutocrinus & $\begin{array}{l}\text { medium } \\
\text { bowl }\end{array}$ & low, high & 1 & Tertibrachitaxis & 3 & yes & yes & present & $\begin{array}{l}\text { strongly, } \\
\text { weakly }\end{array}$ \\
\hline Physetocrinus & $\begin{array}{l}\text { medium } \\
\text { cone, } \\
\text { medium } \\
\text { bowl }\end{array}$ & high & 1 & $\begin{array}{l}\text { Tertibrachitaxis, } \\
\text { Quartibrachitaxis }\end{array}$ & 5 or more & yes & yes & present & $\begin{array}{l}\text { strongly, } \\
\text { weakly }\end{array}$ \\
\hline Eumorphocrinus & $\begin{array}{l}\text { medium } \\
\text { bowl }\end{array}$ & high & 2 & Tertibrachitaxis & 5 or more & yes & yes & absent & strongly \\
\hline Cytidocrinus & $\begin{array}{l}\text { medium } \\
\text { bowl }\end{array}$ & high & 0 & Primibrachitaxis & 4 & yes & yes & absent & strongly \\
\hline
\end{tabular}




\begin{tabular}{|c|c|c|c|c|c|c|c|}
\hline Genus & Arm Lobes & $\begin{array}{c}\text { Arm Lobe } \\
\text { Length } \\
\end{array}$ & $\begin{array}{c}\text { Tegmen as } \\
\text { High as } \\
\text { Calyx } \\
\end{array}$ & $\begin{array}{c}\text { Tegmen Plate } \\
\text { Sculpture }\end{array}$ & Tegmen Shape & $\begin{array}{c}\text { Tegmen Interray } \\
\text { Depressed }\end{array}$ & Anal Opening \\
\hline Cactocrinus & absent & absent & lower, same & smooth, spinose & $\begin{array}{l}\text { low cone, } \\
\text { medium cone, } \\
\text { low inverted } \\
\text { bowl }\end{array}$ & no & $\begin{array}{l}\text { tube present, } \\
\text { central }\end{array}$ \\
\hline Ilmocrinus & absent & absent & unknown & unknown & unknown & no & unknown \\
\hline Teleiocrinus & absent & absent & lower & nodose & flat cone & no & $\begin{array}{l}\text { tube present, } \\
\text { central }\end{array}$ \\
\hline Strotocrinus & absent & absent & lower & smooth & $\begin{array}{c}\text { flat inverted } \\
\text { bowl }\end{array}$ & no & $\begin{array}{c}\text { tube absent, } \\
\text { eccentric }\end{array}$ \\
\hline Maligneocrinus & absent & absent & lower & unknown & unknown & no & unknown \\
\hline Cusacrinus & absent & absent & lower, same & smooth, spinose & $\begin{array}{l}\text { low cone, } \\
\text { medium cone, } \\
\text { flat cone, low } \\
\text { inverted bowl }\end{array}$ & no & $\begin{array}{l}\text { tube present, } \\
\text { central }\end{array}$ \\
\hline Nunnacrinus & absent & absent & lower, same & nodose, spinose & $\begin{array}{l}\text { medium cone, } \\
\text { low inverted } \\
\text { bowl }\end{array}$ & no & $\begin{array}{l}\text { tube present, } \\
\text { central }\end{array}$ \\
\hline Glaphyrocrinus & absent & absent & lower & nodose & $\begin{array}{c}\text { low inverted } \\
\text { bowl }\end{array}$ & no & $\begin{array}{l}\text { tube present, } \\
\text { central }\end{array}$ \\
\hline Manillacrinus & absent & absent & lower, same & nodose & medium cone & no & $\begin{array}{l}\text { tube present, } \\
\text { central }\end{array}$ \\
\hline Thinocrinus & $\begin{array}{c}\text { present, extend } \\
\text { laterally }\end{array}$ & medium & lower & nodose, smooth & $\begin{array}{l}\text { medium cone, } \\
\text { flat cone, flat } \\
\text { inverted bowl, } \\
\text { low inverted } \\
\text { bowl }\end{array}$ & yes & $\begin{array}{l}\text { tube present, } \\
\text { central }\end{array}$ \\
\hline Abactinocrinus & $\begin{array}{c}\text { present, extend } \\
\text { laterally }\end{array}$ & long & lower & nodose & $\begin{array}{c}\text { flat inverted } \\
\text { bowl }\end{array}$ & yes & $\begin{array}{l}\text { tube present, } \\
\text { central }\end{array}$ \\
\hline
\end{tabular}




\begin{tabular}{|c|c|c|c|c|c|c|c|}
\hline Genus & Arm Lobes & $\begin{array}{c}\text { Arm Lobe } \\
\text { Length } \\
\end{array}$ & $\begin{array}{c}\text { Tegmen as } \\
\text { High as } \\
\text { Calyx } \\
\end{array}$ & $\begin{array}{c}\text { Tegmen Plate } \\
\text { Sculpture } \\
\end{array}$ & Tegmen Shape & $\begin{array}{c}\text { Tegmen Interray } \\
\text { Depressed }\end{array}$ & Anal Opening \\
\hline Iotacrinus & $\begin{array}{l}\text { present, extend } \\
\text { laterally }\end{array}$ & medium & lower, higher & nodose & $\begin{array}{c}\text { low inverted } \\
\text { bowl }\end{array}$ & no & $\begin{array}{l}\text { tube present, } \\
\text { eccentric }\end{array}$ \\
\hline Aacocrinus & $\begin{array}{l}\text { present, extend } \\
\text { laterally }\end{array}$ & short & lower & nodose & $\begin{array}{l}\text { flat cone, low } \\
\text { inverted bowl }\end{array}$ & no & $\begin{array}{l}\text { tube present, } \\
\text { eccentric }\end{array}$ \\
\hline Blairocrinus & $\begin{array}{c}\text { present, extend } \\
\text { laterally }\end{array}$ & short & higher & $\begin{array}{c}\text { nodose, smooth, } \\
\text { proximal spines }\end{array}$ & $\begin{array}{l}\text { low cone, } \\
\text { medium cone, } \\
\text { high cone, } \\
\text { medium } \\
\text { inverted bowl }\end{array}$ & no & $\begin{array}{l}\text { tube present, } \\
\text { central }\end{array}$ \\
\hline Sampsonocrinus & $\begin{array}{c}\text { present, extend } \\
\text { laterally }\end{array}$ & short & lower & nodose & $\begin{array}{c}\text { flat inverted } \\
\text { bowl, low } \\
\text { inverted bowl }\end{array}$ & yes & $\begin{array}{l}\text { tube present, } \\
\text { eccentric }\end{array}$ \\
\hline Steganocrinus & $\begin{array}{c}\text { present, extend } \\
\text { laterally }\end{array}$ & long & same & nodose & $\begin{array}{l}\text { flat inverted } \\
\text { bowl, low } \\
\text { inverted bowl }\end{array}$ & no & $\begin{array}{l}\text { tube present, } \\
\text { eccentric }\end{array}$ \\
\hline Actinocrinites & $\begin{array}{l}\text { present, extend } \\
\text { laterally }\end{array}$ & long & lower & nodose & $\begin{array}{l}\text { low cone, flat } \\
\text { cone, low } \\
\text { inverted bowl }\end{array}$ & no & $\begin{array}{l}\text { tube present, } \\
\text { central }\end{array}$ \\
\hline Dialutocrinus & absent & absent & lower & nodose & $\begin{array}{l}\text { low cone, low } \\
\text { inverted bowl }\end{array}$ & no & $\begin{array}{l}\text { tube present, } \\
\text { central }\end{array}$ \\
\hline Physetocrinus & absent & absent & lower & smooth & $\begin{array}{c}\text { flat inverted } \\
\text { bowl, low } \\
\text { inverted bowl }\end{array}$ & no & $\begin{array}{l}\text { tube absent, } \\
\text { eccentric }\end{array}$ \\
\hline Eumorphocrinus & absent & absent & lower & smooth & $\begin{array}{c}\text { low inverted } \\
\text { bowl }\end{array}$ & no & $\begin{array}{l}\text { tube present, } \\
\text { central }\end{array}$ \\
\hline Cytidocrinus & absent & absent & lower & spinose & $\begin{array}{c}\text { low inverted } \\
\text { bowl }\end{array}$ & no & $\begin{array}{c}\text { tube present, } \\
\text { central }\end{array}$ \\
\hline
\end{tabular}




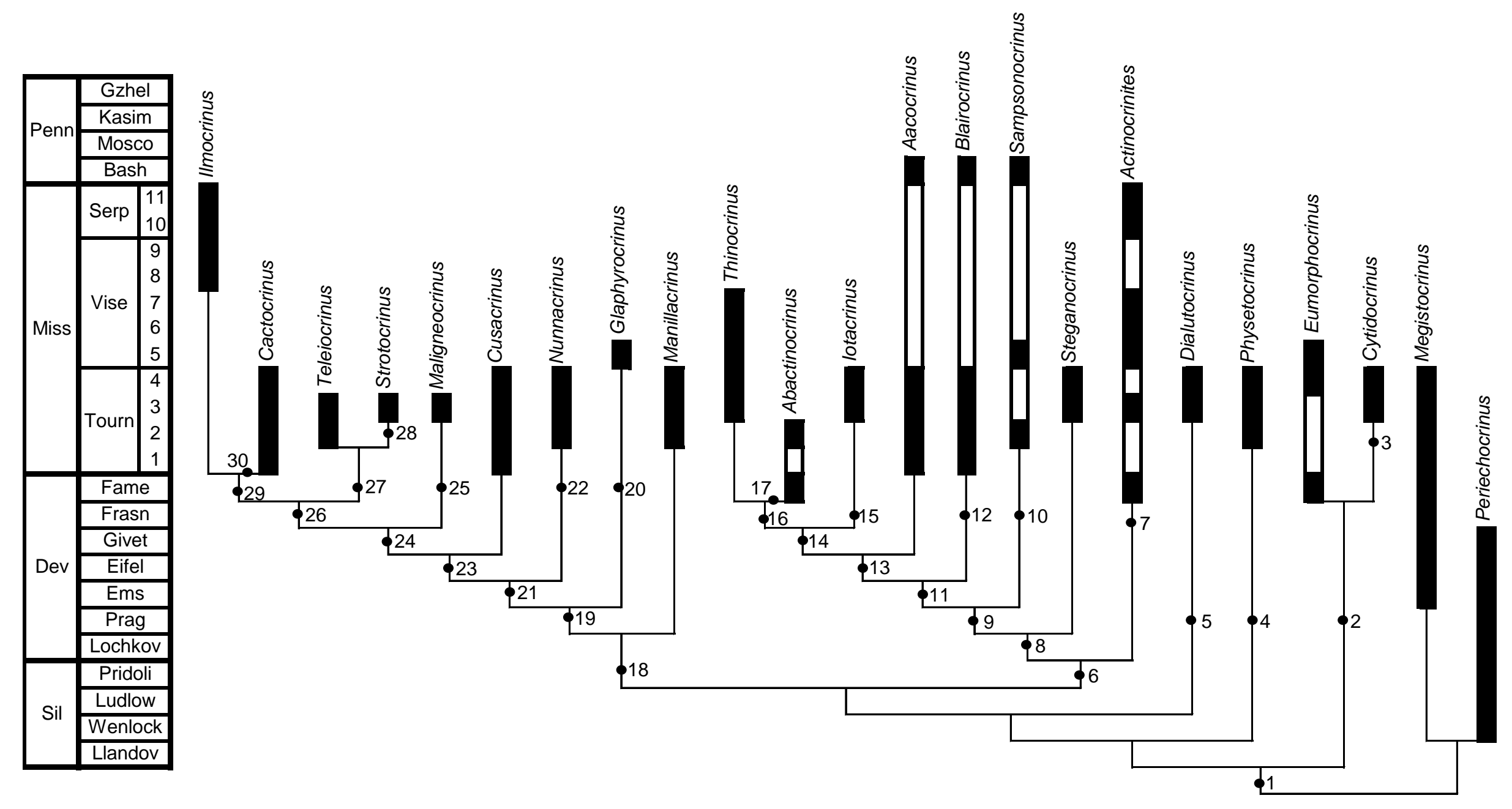


FiguRE 2.1.-Phylogenetic analysis from PAUPC 4.0b10; 23 taxa, 17 characters, 68 character states, all characters were unordered and unweightered; search methods heuristic with random stepwise addition. Rolf's consistency index (C.I.) of 0.56. Thirty apomorphies are as follows: 1 , two plates above primanal; 2 , no fixed interbrachials between half-rays; 3 , no fixed secundibrachials; 4 , anal tube absent; 5 , arms grouped, but arm lobes absent, tertibrachitaxis highest brachitaxis in vertical wall of calyx, calyx medium bowl, three ranges in regular interrays; 6, arm lobes present and extend laterally; 7, high basal circlet, secundibrachitaxis highest brachitaxis in vertical wall of calyx; 8, basal circlet low, anal tube eccentric; 9, arm lobes short in length; 10, tegmen interrays depressed; 11, no fixed interbrachials between half-rays; 12 , tegmen higher than calyx; 13, three ranges in regular interrays; 14, arm lobes medium in length; 15, low bowl calyx; 16, anal tube central and tegmen interrays depressed; 17, arm lobes long in length; 18, arms not lobed; 19, four or more ranges in regular interrays; 20, two fixed secundibrachials; 21, arms not strongly grouped; 22, primibrachitaxis is highest brachitaxis in vertical wall of calyx; 23, secundibrachitaxis is highest brachitaxis in vertical wall of calyx; 24, tertibrachitaxis is highest brachitaxis in vertical wall of calyx; 25, globe shaped calyx; 26, arms not grouped, interrays not in contact with tegmen; 27, five or more ranges in regular interrays; 28 , anal tube absent; 29, fewer than four ranges in regular interrays; 30 , secundibrachitaxis is highest brachitaxis in vertical wall of calyx. 
Chapter 3:

Did North American Mississippian Camerate Crinoids have an Endemic or Cosmopolitan Biogeographic Distribution during the Early Osagean?

\begin{abstract}
Early Mississippian seas over North America provided extensive habitat space for crinoids by extending across most of the continent. During this time, several formations were laid down that preserved a high number of camerate crinoids. By comparing the camerate crinoid faunas at the genus level from the lower Burlington Limestone (IA), the Lake Valley Formation (NM), the Redwall Limestone (AZ), and the Anchor Limestone (NV) differences and patterns can be discerned. Similarities were evaluated using a) presence-absence data with the Jaccard Coefficient, b) percentage of common genera, and c) with rarefaction curves.

The camerate crinoids in each of the formations are thought to mostly be from shallow water settings. The lower Burlington and Lake Valley faunas are nearly equal in generic richness (35 and 31 respectively) with a Jaccard similarity of 0.61 despite being separated by a large distance $(1600 \mathrm{~km})$. Conversely, the Redwall and Anchor faunas have approximately half the number of genera of the lower Burlington and Lake Valley formations and are very dissimilar to one another (similarity of 0.18 ) despite being geographically close. This is the expected pattern for faunal endemism.
\end{abstract}

However, the differences in the number in genera of the Redwall and Anchor limestones as compared to the lower Burlington and Lake Valley are probably taphonomic. The camerates are poorly preserved in the Redwall, due to the early diagenesis that produced the chert and dolomite common in the formation. The Anchor camerates were presumably moved in debris flows from shallow water settings, diminishing the preservation potential of the crinoids. Because neither the Redwall nor the Anchor has a significant number of unique genera and all other genera are a 
subset of the lower Burlington fauna, the seas of North America were probably well connected allowing for the camerate crinoids to widely disperse. Rarefaction curves comparing the Anchor, Redwall, and Lake Valley indicate that the differences in number of genera are likely due to incomplete sample sizes and not necessarily differences in environments. Thus, poor preservation and limited samples have produced an apparent pattern of faunal endemism in what may originally have been cosmopolitan faunas.

\section{INTRODUCTION}

North America was covered by extensive shallow seas during the early Mississippian (Fig. 3.1), and these shallow seas provided the prime environment for crinoids to thrive. The environment was ideal for the stenohaline crinoids because extensive reefs that restricted marine circulation during the Devonian were decimated in the Frasnian-Famennian mass extinction (Copper, 1994; Copper, 2002; Kammer and Ausich, 2006). With the reefs gone, carbonate ramps formed, allowing for normal marine conditions and salinities to expand across epicontinental seas providing crinoids increased habitat space. Another factor that allowed crinoids to prosper was the end-Devonian Hangenberg extinction event that removed many of the crinoids' fish predators from the system (Sallan, et al., 2011). Without as many predators, crinoids diversified rapidly in the early Mississippian.

Of those formations laid down during this time in North America, the Burlington Limestone is the most studied. The significance of the Burlington is in part because it covers a large area. Including the overlying Keokuk Limestone, the exposure of outcrop is 74,000 $\mathrm{km}^{2}$ with a combined thickness more than $50 \mathrm{~m}$ (Ausich, 1997). Burlington Limestone exposures extend over several states, not just at the type locality in Burlington, Iowa (Witzke and Bunker, 
2002). The Burlington is also well known for the crinoids it contains (Wachsmuth and Springer, 1897; Gahn, 2002) with nearly 300 total species within all five major crinoid groups (camerates, primitive cladids, advanced cladids, disparids, and flexibles) throughout the formation (Gahn, 2002).

Although the Burlington is the most widespread and best studied, it is not the only formation with an abundance of early Osagean crinoids. The Lake Valley Formation of New Mexico, Redwall Limestone of Arizona, and Anchor Limestone of Nevada are three of the better studied formations of this time interval with crinoids. Examples of all five groups of crinoids are in both the Lake Valley and Anchor formations, but the Redwall has examples of only camerates, disparids, and advanced cladids. Despite having examples of each of the different groups in all but the Redwall, the camerates are the best represented in all four formations and, therefore, will be the focus of this study.

The Lake Valley, Redwall, and Anchor formations are geographically separated from the Burlington by large distances (the Lake Valley Formation is the closest to the Burlington Limestone at $1600 \mathrm{~km}$ ) and the emergent Transcontinental Arch (Fig. 3.1). The camerates in these formations have extensive overlap in genera, especially comparing each of the three western formations to the Burlington. The questions are: how similar are the genera in these formations, and what are the underlying causes for the differences? By comparing these four formations, biogeographic patterns can be discerned that give a better idea of how interconnected the North American seas were during this time period.

The focus of this study will be on the camerates of the lower Burlington Limestone, the Nunn Member of the Lake Valley Formation, the Thunder Springs and Mooney Falls members of the Redwall Limestone, and the whole of the Anchor Limestone. These are the portions of the 
formations that are coeval with one another (Fig. 3.2) and, in the case of the Redwall and Lake Valley formations, where the majority of the crinoids are found.

\section{AGE RELATIONSHIPS OF FORMATIONS}

The lower Burlington Limestone and the Nunn Member of the Lake Valley Formation are known to be of similar age based initially on the crinoids (Springer, 1884) and later by conodonts. Lane (1974) used conodonts to subdivide the Lake Valley Formation and correlate to the conodont time zones in the Mississippi Valley (Lane and Brenckle, 2001). Brezinski (2000, 2007) showed that the trilobite faunas were similar between the two formations as well.

The Thunder Springs Member and the lower part of the Mooney Falls Member are the only portions of the Redwall that have identifiable crinoids (McKee and Gutschick, 1969b; Brower, 1969), and the crinoids from these units correlate to the classic crinoid faunas of the Burlington and Lake Valley. Several coral species also correlate between the three formations (Sando, 1969).

The interpreted age of the Anchor Limestone has changed considerably since the 1930's (Webster and Lane, 1987, fig. 3). Webster and Lane (1987) assigned a late Kinderhookian/early Osagean age for the Anchor based on the crinoid and conodont fauna. However, Webster (1997) later found conodonts, specifically Polygnathus communis carina, in the basal units of the Anchor which indicate the entirety of the formation is within the Osagean.

Based on the crinoids, conodonts, trilobites, and corals, these four formations are shown to be coeval with each other (Fig. 3.2). All of the relevant parts of the formations were deposited during the early Osagean, or time unit 3 of Ausich and Kammer (2008). 


\section{DEPOSITIONAL ENVIRONMENTS OF THE FORMATIONS}

Lower Burlington: Dolbee Creek and Haight Creek members.-The lower Burlington consists of the lower Dolbee Creek Member and the middle Haight Creek Member (Witzke and Bunker, 2002). The Dolbee Creek Member has a succession of stacked crinoidal packstones and grainstones. These beds may be graded and are interbedded with mudstones and wackestones.

The interbeds are usually dolomitized. The Haight Creek Member is dominated by dolomite that may be cherty to very cherty. There is a middle layer of limestone similar to those found in the Dolbee Creek Member.

The lower part of the Burlington Limestone is thought to have been deposited entirely within the middle-shelf area (Witzke and Bunker, 2002). The middle-shelf is characterized by normal salinity, good circulation, and bottom conditions below normal wave base but above storm wave base (Wilson and Jordan, 1983). The Burlington is considered to be a good example of middle-shelf deposits (Witzke and Bunker, 2002). It is characterized by having slow average rates of subtidal sediment accumulation and being subjected to varying degrees of storm activity depending on the water depth. The lack of evidence for peritidal and mudflat/sabkha facies or exposure surfaces supports the hypothesis that the Burlington was deposited in subtidal environments. Episodic storm-current activity is thought to be the reason why graded to amalgamated bedforms of crinoidal packstone and grainstone were formed. The grainstones interbedded between these graded beds are formed by dolomitized or silicified mudstones. These mudstones are interpreted to have formed between storms when bottom conditions were quiet and currents were unable to winnow the muds.

Lake Valley Formation: Nunn Member.—The Nunn Member is a highly fossiliferous, soft, blue-grey to greenish-grey nodular carbonate packstone to wackestone interbedded with 
shales and argillaceous limestones (Laudon and Bowsher, 1949; Jicha, 1954; Pray, 1951; Kues, 1986; Frank et al., 1996; Brezinski, 2000).

Although the formation is typically associated with deep-water Waulsortian mounds in the Alamogordo Member, the deposition of most of the Lake Valley sediments took place on a shallow marine carbonate shelf known as the Lake Valley Shelf (Lane and De Keyser, 1980; Kues, 1986). The sediments are thickest to the north and wedge out southward into a lowerenergy, most likely deep-water, sediment-starved basin (Kues, 1986; Batchel and Dorobek, 1998). The Nunn Member was laid down by a transgressive system (Batchel and Dorobek, 1998), and its thickness varies greatly throughout the extent of the Lake Valley Formation. This is due to the differences in paleogeographic setting (Brezinski, 2000). To the east in the Sacramento Mountains, the Nunn is a flank bed to the Waulsortian mounds (Lane, 1982). In the San Andres Mountains and farther west where most of the crinoids occur, the Nunn was probably deposited as a level bottom facies in a shelf environment (Brezinski, 2000).

Redwall Limestone: Thunder Springs and Mooney Falls members.-The packstone that constitutes the Redwall Limestone was deposited on what is known as the Redwall Shelf (Witzke and Bunker, 2002). The Thunder Springs Member consists of thin beds and elongate lenses of chert that alternate with thin beds of limestone or dolomite (McKee and Gutshick, 1969a). The dolomite is finely crystalline, and the limestone ranges from fine to very coarse. The grains of the limestone are composed of fossil fragments and peloids. The Mooney Falls Member consists of thick to very thick beds of packstone with zones of chert near the top of the member. The environment has been interpreted as having normal marine conditions, good circulation, and shallow to moderate depths. 
The Thunder Springs Member is interpreted to have been laid down during a regression (McKee and Gutshick, 1969a). This is indicated by thin bedding thought to have formed by a shallow base level and consistent interruptions to sedimentation. This member has an abundant amount of chert that is likely due to early diagenesis because it is uniformly distributed across the region. The chert probably formed before the dolomite (also thought to be due to early diagenesis) because the external molds of fossils preserved in the chert have excellent preservation of detail, but details are very poorly preserved in the dolomite.

The Mooney Falls Member was laid down during a time of maximum transgression with few interruptions to sedimentation (McKee and Gutshick, 1969a). There was very little terrigenous sediment input in this member.

The crinoids in both of these members have a similar distribution pattern which may indicate that the environment for the two members was similar (Brower, 1969). The preservation of the crinoids in the Thunder Springs Member (within the chert) does make this speculation questionable because the environment in which the bedded chert was formed is not well understood (McKee and Gutshick, 1969b). However, it is probable that the crinoids preferred living along depositional topographic highs as their calyces have not been collected away from these highs (Brower, 1969). Sedimentation rates that buried the crinoids were presumably moderate to high when calyces are found within the formation, and very slow where only crinoidal debris is preserved.

Anchor Limestone.-Webster and Lane (1987) separated the Anchor into three sections; lower, middle, and upper. The lower section is composed of packstone to grainstone with a general increase in grain size upward. Chert beds and nodules are also present. The middle section is composed of wackestone to packstone that contain some chert nodules and 
discontinuous thin bands of chert. The upper member is packstone to grainstone with graded beds and crossbedding.

The Anchor Limestone has evidence that it was deposited in a high-energy setting (Webster and Lane, 1987). Webster and Lane (1987) stated that the crinoids in the Anchor suggest a mix of two environments. The disparids and flexibles in the Anchor still have portions of their arms attached, which is indicative of burial near where they lived, at the base of a slope. The base of the slope environment is suggested because disparids dominate the base of the Borden Delta (Ausich et al., 1979). The species of conodonts found in the Anchor also suggest a base of slope environment (Webster and Lane, 1987). The camerates lack arms and columns and are therefore likely to have been transported by debris flows. The camerates probably lived on a shallow platform and were transported to their burial sites. However, taphonomic studies on crinoids (Donovan, 1991; Ausich, 2001; Baumiller, 2008) show that the arms will be the first to disarticulate, even without transportation. The camerates may have been buried near where they lived, but they were exposed longer, allowing for the disarticulation of the arms. If this is the case, the depositional environment for the Anchor camerates is not the shallow shelf of the other formations, but rather the base of a slope.

\section{CRINOID FAUNAS}

The camerate crinoids are the focus of this study because they represent the majority of the crinoids in the four formations. This bias toward the camerates is undoubtedly due to the structure of the calyx, which has rigidly connected plates (Ubaghs, 1978, Ausich et al., 1999), giving them higher preservation potential. 
The information used to conduct this study came from both published and compiled crinoid lists for the formations. The lists of genera were determined from the following sources: for the Burlington, Gahn (2002); for the Lake Valley, Rhenberg and Kammer (ms); for the Redwall, Brower (1969); and for the Anchor, Webster and Lane (1987). These lists were updated using new generic concepts (Ausich and Kammer, 2008; 2009; 2010; Rhenberg, Ausich, and Kammer, ms). With the information given for the Lake Valley, Redwall, and Anchor formations, the number of specimens for each genus was also noted to determine those genera that were the most prominent or common in each formation (Fig. 3.3). The Burlington Limestone is not included in the counts because it is impractical to track down and count the thousands of crinoids that have been collected from that formation and are stored in major museum collections (e.g. Smithsonian Institution, Harvard University, etc.)

Table 3.1 lists the different camerate genera from the four formations. The Burlington Limestone has the most at 35 with five of those genera known exclusively within the Burlington (of the four formations in this study). The Nunn Member of the Lake Valley Formation has almost as many genera (31), with three that are unique to it. The Redwall and the Anchor have half the number of known genera (18 and 15 respectively), and they have one unique genus each. Only five genera occur in all four formations; these are Steganocrinus, Physetocrinus, Agaricocrinus, Platycrinites, and Plemnocrinus.

\section{FAUNAL SIMILARITY}

The degree of similarity between the faunas was evaluated using the Jaccard Coefficient along with non-metric multidimensional scaling (MDS) with PAST software (Hammer et al., 
2001; Table 3.2; Fig. 3.4). The Jaccard Coefficient emphasizes similarity by using the following formula:

$$
J=\frac{a}{a+b+c}
$$

Where $\mathrm{a}=$ number of shared genera, $\mathrm{b}=$ number of unique genera in one sample, and $\mathrm{c}=$ number of unique genera in the other sample. The Burlington and the Lake Valley formations are fairly similar at 0.61 similarity. Twenty-five genera occur in both formations (Table 3.3.1) despite being separated by a great distance ( 1600 km). Conversely, the Redwall and Anchor limestones are located closest to each other ( $200 \mathrm{~km})$ but share very few similar genera (0.18 similarity). The only genera that the Redwall and Anchor share are the five genera present in all four formations. The MDS plots suggest that some genera are cosmopolitan plotting in the center of the R-mode MDS graph (Fig. 3.4.1), whereas others appear to be endemic plotting far from the center and characterizing individual formations (Fig. 3.4.1).

Also examined was similarity based on shared genera using the formula:

$$
\mathrm{S}=\overline{\mathrm{N}} \underset{\text { of smaller fauna }}{\mathrm{a}}
$$

This formula calculates the percentage of genera in the smaller fauna that are shared with the larger fauna. This formula basically shows how similar two faunas are based on the genera available from the smaller fauna, ignoring the effect of missing genera. Thus, a smaller fauna that is a complete subset of a larger fauna would be $100 \%$ similar. Although the Redwall and the Anchor each have approximately half the number of genera than the Burlington, most of the genera in both are also in the Burlington. Sixteen of the 18 genera in the Redwall and 12 of the 15 in the Anchor are also in the Burlington Limestone giving them $89 \%$ and $80 \%$ shared genera, 
respectively, with the Burlington. (Table 3.3.2). However, the Anchor and the Redwall appear to be relatively different subsets of the Burlington because the similarity between the Anchor and Redwall is only 33\%.

Rarefaction curves were also created to allow for the comparison of the Lake Valley, Redwall, and Anchor formations (Fig. 3.5). Rarefaction is a resampling technique that allows for samples of different sizes to be compared (Raup, 1975; Foote, 1992; Kammer et al., 1997). This is done by interpolating how many species there would be if the sample sizes were standardized (Raup, 1975). The standardization allows for samples of various sizes to be compared more directly. With the rarefaction method, the raw total number of taxa or specimens are not compared, but rather the diversity or abundance curves that are created (Sanders, 1968). Curves generated indicate whether or not the number of samples collected are sufficient (Gotelli and Colwell, 2001). If the numbers of samples are insufficient, rarefaction curves are steep indicating more taxa should be found with additional samples. With increasing sample size the curves should begin to flatten. When sampling is sufficient, an asymptote is reached. If curves of different length overlap, or plot closely together, the assumption is that the sampled populations are similar. If the curves are widely separated, no matter their lengths, then the underlying populations are probably different.

Though actual numbers of specimens are known for the western formations, the lower Burlington was modeled on the logarithmic decline of the genera of the Lake Valley Formation multiplied by ten (Fig. 3.5.3). This increase of an order of magnitude for the Burlington is certainly an underestimate of the number of specimens in known collections, but it gives a general idea of how the Burlington compares to the other formations and the asymptote is reached around 15,000 specimens. 


\section{DISCUSSION}

An organism that exhibits cosmopolitanism is one that occurs globally or spans a large area such as an ocean basin, whereas an endemic organism is one that is restricted to certain areas or regions (Spellerberg and Sawyer, 2000). For this study, these terms reference only North America where cosmopolitanism refers to genera found across the Mississippian continent and endemic genera are those found only in a single formation. The only truly cosmopolitan genera in this study are Steganocrinus, Physetocrinus, Agaricocrinus, Platycrinites, and Plemnocrinus, as they occur in all four formations across North America. This would indicate that these genera were less restricted in their habitat than other taxa; or they had a better ability to overcome any barriers between the formations by larval dispersal. The endemic genera (in terms of this study) would be those few that are found exclusively in one formation. The endemic taxa in the lower Burlington Limestone are Megistocrinus, Cytidocrinus, Azygocrinus, Gongylocrinus, and Laticrinus; the Lake Valley Formation has Blairocrinus, Iotacrinus, and Eucladocrinus; the Redwall Limestone has Actinocrinites; and the Anchor Limestone has Tarantocrinus. Of the mentioned endemic genera, Megistocrinus, Actinocrinites, Blairocrinus, Cytidocrinus, Iotacrinus, and Eucladocrinus are in other formations across the world; Azygocrinus, Gongylocrinus, and Laticrinus are only known in the Burlington Limestone and Tarantocrinus is only known from the Anchor Limestone. The endemic genera may have been restricted to particular environments or not have had the ability to move long distances or past barriers during their larval dispersal stage. All other genera are in more than one formation, with most being found in the lower Burlington. 
The numbers of camerate genera in each of these four formations are distinctly different. The raw distribution of genera across North America would suggest a pattern more closely associated with endemism than cosmopolitanism. This is especially true if only the Redwall and Anchor limestones are taken into account as the only shared genera are the five known in all four formations. However, the genera in the Redwall and Anchor are not truly endemic as both share a number of genera with the lower Burlington Limestone. There is a high similarity between the shared genera of all formations to the lower Burlington. For example, of the 18 genera in the Redwall Limestone, 16 of those also occur in the lower Burlington Limestone, which equates to an $89 \%$ similarity (Table 3.3). Because such a high similarity exists between the lower Burlington and the western formations in terms of shared genera, endemism cannot be the true pattern for Osagean camerates. The high similarity and the high number of endemic genera make it conceivable that the Burlington was a center of evolutionary origin for the North American Osagean camerates. Because the Burlington Shelf covered such a large area that was ideal for crinoids, they may have started in that area and dispersed to the other formations during the early Osagean. But it may be just as likely that the extensive amount of Burlington Limestone that is preserved and weathers easily creates a "taphonomic window" that provides diverse and abundant specimens . Whatever the reason for the high numbers of Burlington taxa, the high similarity between shared genera contradicts the Jaccard Coefficient (Table 3.2), which considers overall similarity based on presence and absence of genera in each fauna, not just shared genera, and indicates that only the Lake Valley is similar to the lower Burlington. What might have caused the disparity in diversity?

It is unlikely that the reason for the difference is due to different environments as the camerates in all four formations were living on a shallow carbonate shelf. Distance may be a 
reason for the disparity because the greater the distance between two areas, the more likely an organism will encounter barriers that need to be overcome (Mayr, 1970). However, distance is unlikely a reason for the difference because of the high similarity of shared genera between the camerates in the Burlington Limestone and those in the Redwall and Anchor limestones. This suggests that the most likely reasons for the differences in number of genera is either taphonomic in origin or due to uneven sample sizes.

The plates of crinoids are held together by ligaments known as "mutable collagenous tissues” or MCTs (Donovan, 1991; Baumiller, 2008). Once the MCTs decay, the plates begin to fall apart (Donovan, 1991). MCTs may decay quickly. Cain (1968) showed that an extant comatulid crinoid completely disarticulated within two days, even in an anaerobic and unagitated environment. However, not all MCTs will decay so quickly (Donovan, 1991). Some pluricolumnals (partially fragmented columns) were sturdy enough to produce tool marks, orient to the current, and survive downhill saltation with little fragmentation. Camerate crinoids have calyx plates that are strongly sutured (Ubaghs, 1978), making it more difficult for them to disarticulate. Disarticulation of crinoid plates could take between days to a couple of weeks, dependent on the conditions of the environment (agitation, presence of scavengers, temperature, etc.) where the crinoid died (Donovan, 1991; Ausich et al., 1999). To preserve a complete crinoid, the crinoid must be buried rapidly and deep enough so that it is not re-excavated by currents or disrupted by scavengers (Ausich et al., 1999).

As previously mentioned, the Redwall Limestone was subjected to early diagenesis from both chert and dolomite replacement (McKee and Gutshick, 1969a), which would not be conducive to the preservation of fossils. Diagenesis often has a destructive effect on fossils (Tucker, 1991) and poor preservation limits the ability to correctly identify the crinoids (Brower, 
1969). The Anchor Limestone has a similar problem because the camerates may have been moved in debris flows from the shallow shelf environment (Webster and Lane, 1987). This movement would lower preservation potential of camerates as even the calyx became disarticulated.

Another issue that may be the cause of the disparity in diversity is the limited amount of sampling that has occurred for the western formations. The Burlington Limestone has been collected from for well over a century (Wachsmuth and Springer, 1897; Gahn, 2002) and the Lake Valley Formation has long been noted as having an abundance of crinoids (Kues, 1986) and recent work done by Rhenberg and Kammer (ms) identified more than 4,400 camerates (Fig. 3.3.1) out of more than 7,000 specimens collected by Brad Macurda. Neither the Redwall Limestone nor the Anchor Limestone have anywhere near that number of crinoids. Only one major study of the crinoids has been conducted for each of the Redwall and Anchor limestones. In the Redwall study (Brower, 1969), 245 specimens (Fig. 3.3.2) were collected, whereas in the Anchor study (Webster and Lane, 1987), only 88 (Fig. 3.3.3) were collected. These numbers reflect the limited exposures, poor preservation, and potential weathering of specimens from the rocks.

Rarefaction curves were created for these three formations using the PAST software with the numbers gathered from the different studies (Fig. 3.3.1-3). When all three curves are plotted together (Fig. 3.5.1) it becomes clear that the most likely cause for the differences in camerate genera is due to sampling issues. Neither the Redwall nor the Anchor limestones approach an asymptote as the Lake Valley Formation does, which indicates that the former formations require more sampling. Before the current study of the Lake Valley Formation (Rhenberg and Kammer, ms), only 16 genera were reported; with the addition of the 4500 specimens, the number of 
genera nearly doubled. If more extensive sampling were completed for the Redwall and the Anchor, it is likely that the genus richness gaps would be filled and the formations would show much more similarity in camerate crinoids. When the Lake Valley numbers are removed from the rarefaction curve (Fig. 3.5.2), the same steep trend occurs and the Redwall curve does not begin to reach its asymptote, which indicates that if more specimens were collected, the diversity of the formation would most likely increase.

The inferred similarity between the formations indicates that all four formations were connected to each other during the Mississippian via marine currents that would allow for the dispersal of crinoid larvae. Localized environmental differences may have allowed for the unique genera to take hold in specific formations and not the others, but for the most part, the camerate crinoids of the Early Mississippian North American seas appear to have originally been cosmopolitan.

\section{CONCLUSIONS}

The differences in the numbers of camerate crinoid genera between the four major early Osagean formations of North America is most likely due to uneven sampling of these formations. Whereas the lower Burlington Limestone and the Nunn Member of the Lake Valley Formation have relatively well preserved crinoids that are easy to collect, the Redwall and Anchor limestones lack both good preservation and collectability. The early diagenesis which produced chert and dolomite in the Redwall and movement of crinoids by debris flows in the Anchor have made collecting identifiable crinoids difficult. If preservation and collectability were better for the Redwall and Anchor, it is likely that more of the genera in the Burlington and Lake Valley formations would also be found in the western formations. If more sampling were 
to be done on the western formations, some of the gaps in genus richness might be filled. Thus, it may be inferred that an ostensible pattern of biogeographic endemism in early Osagean camerates, as illustrated by MDS using the Jaccard Coefficient, resulted from poor preservation of an originally widely dispersed cosmopolitan fauna. 


\section{REFERENCES}

Ausich, W. I. 1997. Chapter 19, Regional encrinites: A vanishing lithofacies, p. 509-519. In C. E. Brett and G. C. Baird (eds.), Paleontological events stratigraphic, ecological, and evolutionary implications. A. A. Balkema, Rotterdam.

Ausich, W. I. 2001. Echinoderm Taphonomy, p. 171-227. In M. Jangoux and J. M. Lawrence (eds.), Echinoderm Studies-Volume 6. Columbia University Press, New York, NY.

Ausich, W. I., C. E. Brett, and H. Hess. 1999. Taphonomy, p. 50-54. In H. Hess, W. I. Ausich, C. E. Brett, and M. J. Simms (eds.), Fossil Crinoids. Cambridge University Press.

Ausich, W. I. and T. W. Kammer. 2008. Generic concepts in the Amphoracrinidae Bather, 1899 (Class Crinoidea) and evaluation of generic assignments of North American species. Journal of Paleontology, 82:1139-1149.

Ausich, W. I. and T. W. Kammer. 2009. Generic concepts in the Platycrinitidae Austin and Austin, 1842 (Class Crinoidea). Journal of Paleontology, 83:694-717.

Ausich, W. I. and T. W. Kammer. 2010. Generic concepts in the Batocrinidae Wachsmuth and Springer, 1881 (Class Crinoidea). Journal of Paleontology, 84:32-50.

Ausich, W. I., T. W. Kammer, and N. G. Lane. 1979. Fossil communities of the Borden (Mississippian) Delta in Indiana and Northern Kentucky. Journal of Paleontology, 53:11821196.

Bachtel, S. L., And S.L. DorobeK. 1998. Mississippian carbonate ramp-to-basin transitions in south-central New Mexico; sequence stratigraphic response to progressively steepening outer-ramp profiles. Journal of Sedimentary Research. 68:1189-1200.

Baumiller, T. K. 2008. Crinoid ecological morphology. Annual Review of Earth and Planetary Sciences. 36:221-249.

Blakey, R. C. 2007. Paleogeography and Geologic Evolution of North America. http://www2.nau.edu/rcb7/nam.html.

Brezinski, D. K. 2000. Lower Mississippian trilobites from southern New Mexico. Journal of Paleontology. 74:1043-1064.

BREZINSKI, D. K. 2007. Lower Mississippian trilobite biostratigraphy of the central United States, and some new Osagean species. Journal of Paleontology. 81:737-745.

Brower, J. C. 1969. Chapter 12, Crinoids, p. 475-543. In E. D. McKee and R. C. Gutschick (eds.), History of the Redwall Limestone of northern Arizona. Geological Society of America Memoir 114. 
Cain, J. D. B. 1968. Aspects of the depositional environment and palaeoecology of crinoidal limestones. Scottish Journal of Geology. 4:191-208.

Copper, P. 1994. Ancient reef ecosystem expansion and collapse. Coral Reefs. 13:3-11.

Copper, P. 2002. Reef development at the Frasnian/Famennian mass extinction boundary. Palaeogeography, Palaeoclimatology, Palaeoecology. 181:27-65.

Donovan, S. K. 1991. The taphonomy of echinoderms: calcareous multi-element skeletons in the marine environment, p. 241-269. In S. K. Donovan (ed.) The Processes of Fossilization, Columbia University Press.

Foote, M. 1992. Rarefaction analysis of morphological and taxonomic diversity. Paleobiology. 18:1-16.

Frank, T. D., K. C. Lohmann, and W. J. Meyers. 1996. Chronostratigraphic significance of cathodoluminescence zoning in syntaxial cement; Mississippian Lake Valley Formation, New Mexico. Sedimentary Geology 105:29-50.

GaHn, F. J., 2002. Crinoid and blastoid biozonation and biodiverstiy in the Early Mississippian (Osagean) Burlington Limestone. Iowa Department of Natural Resources Guidebook. 23:5374.

Gotelli, N. J. And R. K. Colwell. 2001. Quantifying biodiversity: procedures and pitfalls in the measurement and comparison of species richness. Ecology Letters. 4:379-391.

Hammer, Ø., D. A. T. Harper, and P. D. Ryan. 2001. Paleontological Statistics (PAST) v. 2.03. $<$ http://folk.uio.no/ohammer/past/>.

JichA, H. L.,Jr. 1954. Geology and mineral deposits of Lake Valley Quadrangle, Grant, Luna, and Sierra counties, New Mexico. Bulletin - New Mexico Bureau of Geology \& Mineral Resources. 93p.

Kammer, T. W. and W. I. Ausich. 2006. The “Age of Crinoids” a Mississippian biodiversity spike coincident with widespread carbonate ramps. Palaios, 21:238-248.

Kammer, T. W., T. K. Baumiller, AND W. I. Ausich. 1997. Species longevity as a function of niche breadth: Evidence from fossil crinoids. Geology. 25:219-222.

Kues, B. S. 1986. Paleontology of the Caballero and Lake Valley formations (Lower Mississippian) west of the Rio Grande, south-central New Mexico; Truth or Consequences region. Guidebook - New Mexico Geological Society. 37:203-214.

Lane, H. R. 1974. Mississippian of Southeastern New Mexico and West Texas-A wedge-onwedge relation. The American Association of Petroleum Geologists Bulletin, 58:269-282. 
Lane, H. R. 1982. The distribution of the Waulsortian facies in North America as exemplified in the Sacramento Mountains of New Mexico, p. 96-114. In K. Bolton, H. R. Lane, D. V. LeMone (eds.). Symposium on the paleoenvironmental setting and distribution of the Waulsortian facies.

Lane, H. R. and P. L. Brenckle. 2001. Type Mississippian subdivisions and biostratigraphic succession, p. 83-107. In P.H. Heckle (ed.) Stratigraphy and Biostratigraphy of the Mississippian Subsystem (Carboniferous System) in its Type Region, the Mississippi River Valley of Illinois, Missouri, and Iowa. I.U.G.S. Subcommission on Carboniferous Stratigraphy Guidebook for Field Conference, St. Louis, MO.

Lane, H. R., and De Keyser, T. L. 1980. Paleogeography of the late Early Mississippian (Tournaisian) in the central and southwestern United States, p. 149-162. In T. D. Fouch and E. R. Magathan (eds). Paleozoic paleogeography of the West-central United States; Rocky Mountain paleogeography symposium 1.

Laudon, L. R., and A. L. Bowsher. 1949. Mississippian formations of southwestern New Mexico. Geological Society of America Bulletin. 60:1-37.

Mayr, E. 1970. Populations, Species, and Evolution. Belknap Press of Harvard University Press. Cambridge. 453 p.

McKee, E. E. And R. C. Gutshick. 1969a. Chapter 2, Sequence of sediments and unconformities, p. 13-95. In E. D. McKee and R. C. Gutschick (eds.), History of the Redwall Limestone of northern Arizona. Geological Society of America Memoir 114.

McKee, E. E. And R. C. Gutshick. 1969b. Chapter 4, The Redwall faunas, p. 125-172. In E. D. McKee and R. C. Gutschick (eds.), History of the Redwall Limestone of northern Arizona. Geological Society of America Memoir 114.

Pray, L. C. 1961. Geology of the Sacramento Mountains escarpment, Otero County, New Mexico. Bulletin - New Mexico Bureau of Geology \& Mineral Resources. 144 p.

Raup, D. M. 1975. Taxonomic diversity estimation using rarefaction. Paleobiology. 1:333-342.

Rhenberg, E. C., W. I. Ausich, and T. W. Kammer. (in prep). Generic concepts in the Actinocrinitidae Austin and Austin, 1842 and evaluation of generic assignments of North American species. [intended for Journal of Paleontology].

Rhenberg, E. C. And T. W. Kammer. (in prep). Camerate crinoids of the Lower Mississippian Lake Valley Formation (Nunn Member, Osagean), New Mexico. [intended for Journal of Paleontology].

Sallan, L. C., T. W. Kammer, W. I. Ausich, and L. A. Cook. 2011. Persistent predator-prey dynamics revealed by mass extinction. Proceedings of the National Academy of Science, 108:8335-8338. 
SAnders, H. L. 1968. Marine benthic diversity: A comparative study. The American Naturalist. 102:243-282.

Sando, W. J. 1969. Chapter 6, Corals, p. 257-343. In E. D. McKee and R. C. Gutschick (eds.), History of the Redwall Limestone of northern Arizona. Geological Society of America Memoir 114.

Spellerberg, I. F. And J. W. D. Sawyer. 2000. An Introduction to Applied Biogeography. Cambridge University Press. 243 p.

Springer, F. 1884. On the occurrence of the lower Burlington limestone in New Mexico. American Journal of Science. 27:97-103.

Tucker, M. E. 1991. The diagenesis of fossils, p. 83-104. In S. K. Donovan (ed.) The Processes of Fossilization, Columbia University Press.

Ubaghs, G. 1978. Camerata, p. T408-T519. In R. C. Moore and K. Teichert (eds.), Treatise on Invertebrate Paleontology, Echinodermata, Pt. T(2). Geological Society of America and University of Kansas Press, Boulder and Lawerence.

Wachsmuth, C. and F. Springer. 1897. The North American Crinoidea Camerata. Harvard College Museum of Comparative Zoology Memoirs, 20 and 21, 897 p.

Webster, G. D. 1997. Lower Carboniferous echinoderms from northern Utah and western Wyoming. Utah Geological Survey Bulletin 128, Paleontology Series, 1:65 p.

Webster, G. D. and N. G. Lane. 1987. Crinoids from the Anchor Limestone (Lower Mississippian) of the Monte Cristo Group Southern Nevada. University of Kansas Paleontological Contributions Paper, 119, 55 p.

Wilson, J. L. ANd C. Jordan. 1983. Middle Shelf Environment, p. 297-343. In P. A. Scholle, D. G. Bebout, and C. H. Moore (eds.), Carbonate Depositional Environments. AAPG Memoir 33.

Witzke B. J. And B. J. Bunker., 2002. Bedrock geology in the Burlington area, southeast Iowa. Iowa Department of Natural Resources Guidebook. 23:53-74. 
TABLE 3.1.-Generic list of the camerates found in the lower Burlington Limestone, Lake Valley Formation (Nunn Member), Redwall Limestone (Thunder Springs and Mooney Falls members), and Anchor Limestone.

\begin{tabular}{|c|c|c|c|}
\hline Burlington & Lake Valley & Redwall & Anchor \\
\hline \multicolumn{4}{|c|}{ Rhodocrinitidae } \\
\hline & Rhodocrinites & Rhodocrinites & \\
\hline Cribanocrinus & Cribanocrinus & Cribanocrinus & \\
\hline Gilbertsocrinus & Gilbertsocrinus & & \\
\hline \multicolumn{4}{|c|}{ Periechocrinidae } \\
\hline Aryballocrinus & \multirow{2}{*}{\multicolumn{2}{|c|}{ Aryballocrinus }} & \\
\hline Megistocrinus & & & \\
\hline \multicolumn{4}{|c|}{ Amphoracrinidae } \\
\hline & Amphoracrinus & & Amphoracrinus \\
\hline Ancalocrinus & Ancalocrinus & & Ancalocrinus \\
\hline Dilatocrinus & & & Dilatocrinus \\
\hline Displodocrinus & Displodocrinus & & Displodocrinus \\
\hline \multicolumn{4}{|c|}{ Actinocrinitidae } \\
\hline & \multicolumn{3}{|c|}{ Actinocrinites } \\
\hline Aacocrinus & $\begin{array}{l}\text { Aacocrinus } \\
\text { Blairocrinus } \\
\text { Iotacrinus }\end{array}$ & & Aacocrinus \\
\hline Steganocrinus & Steganocrinus & Steganocrinus & Steganocrinus \\
\hline Thinocrinus & & & Thinocrinus \\
\hline Cytidocrinus & & & \\
\hline Cactocrinus & Cactocrinus & Cactocrinus & \\
\hline Cusacrinus & Cusacrinus & & Cusacrinus \\
\hline Nunnacrinus & Nunnacrinus & Nunnacrinus & \\
\hline Teleiocrinus & Teleiocrinus & & \\
\hline Physetocrinus & Physetocrinus & Physetocrinus & Physetocrinus \\
\hline \multicolumn{4}{|c|}{ Batocrinidae } \\
\hline Abatocrinus & Abatocrinus & Abatocrinus & \\
\hline \multicolumn{4}{|l|}{ Azygocrinus } \\
\hline Eretmocrinus & Eretmocrinus & & Eretmocrinus \\
\hline Eutrochocrinus & Eutrochocrinus & & \\
\hline \multicolumn{4}{|l|}{ Gongylocrinus } \\
\hline Macrocrinus & & Macrocrinus & \\
\hline Simatocrinus & Simatocrinus & & \\
\hline Uperocrinus & Uperocrinus & Uperocrinus & \\
\hline \multicolumn{4}{|c|}{ Coelocrinidae } \\
\hline Agaricocrinus & Agaricocrinus & Agaricocrinus & Agaricocrinus \\
\hline Aorocrinus & & Aorocrinus & \\
\hline
\end{tabular}




\begin{tabular}{|c|c|c|c|}
\hline Dorycrinus & \multicolumn{3}{|c|}{ Dorycrinus } \\
\hline \multicolumn{4}{|c|}{ Unknown Family } \\
\hline & & & Tarantocrinus \\
\hline \multicolumn{4}{|c|}{ Dichocrinidae } \\
\hline Dichocrinus & Dichocrinus & Dichocrinus & \\
\hline Strimplecrinus & Strimplecrinus & Strimplecrinus & \\
\hline \multicolumn{4}{|c|}{ Platycrinitidae } \\
\hline Platycrinites & Platycrinites & Platycrinites & Platycrinites \\
\hline Collicrinus & Collicrinus & & \\
\hline Elegantocrinus & Elegantocrinus & & \\
\hline & Eucladocrinus & & \\
\hline \multicolumn{4}{|l|}{ Laticrinus } \\
\hline & Oenochoacrinus & & Oenochoacrinus \\
\hline Plemnocrinus & Plemnocrinus & Plemnocrinus & Plemnocrinus \\
\hline Pleurocrinus & Pleurocrinus & Pleurocrinus & \\
\hline
\end{tabular}

TABLE 3.2.- Similarity matrix based on the Jaccard Coefficient (see text).

\begin{tabular}{lrrrr}
\hline \hline & \multicolumn{2}{c}{ Lake } & & \\
& Burlington & Valley & Redwall & Anchor \\
\hline Burlington & 1 & & & \\
Lake Valley & 0.68 & 1 & & \\
Redwall & 0.43 & 0.41 & 1 & \\
Anchor & 0.32 & 0.32 & 0.18 & 1 \\
\hline
\end{tabular}


TABLE 3.3.- Number of genera and similarity between the Burlington, Lake Valley, Redwall, and Anchor formations: 1) Actual counts of genera found in the formations with the number of similar genera between formations; 2) Percentage of common genera found between formations. Similarity based on shared genera, with number of shared genera divided by the total number in the smaller fauna.

\begin{tabular}{lrrrr}
\hline \hline & Burlington & Lake Valley & Redwall & Anchor \\
\hline Burlington & $\mathbf{3 5}$ & & & \\
Lake Valley & 25 & $\mathbf{3 1}$ & & \\
Redwall & 16 & 14 & $\mathbf{1 8}$ & \\
Anchor & 12 & 12 & 5 & $\mathbf{1 5}$ \\
\hline
\end{tabular}

\begin{tabular}{|c|c|c|c|c|}
\hline & Burlington & Lake Valley & Redwall & Anchor \\
\hline Burlington & $100 \%$ & & & \\
\hline Lake Valley & $81 \%$ & $100 \%$ & & \\
\hline Redwall & $89 \%$ & $78 \%$ & $100 \%$ & \\
\hline Anchor & $80 \%$ & $80 \%$ & $33 \%$ & $100 \%$ \\
\hline
\end{tabular}




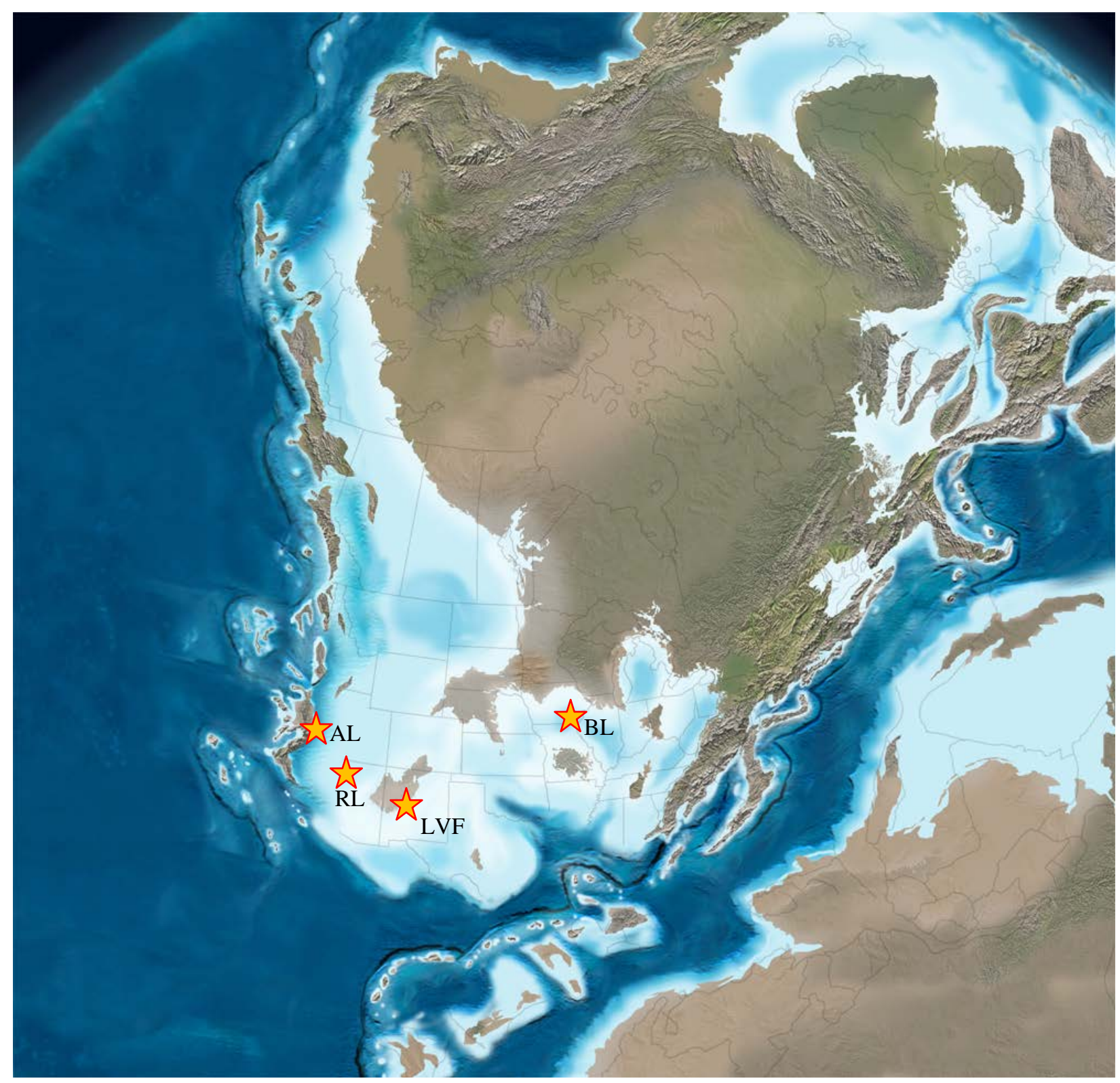

FIGURE 3.1.-Paleogeographic reconstruction of North America in the early Mississippian (Blakey, 2007). Stars indicate location of the Burlington Limestone (BL) in Iowa, Lake Valley Formation (LVF) in New Mexico, Redwall Limestone (RL) in Arizona, and Anchor Limestone (AL) in Nevada. 


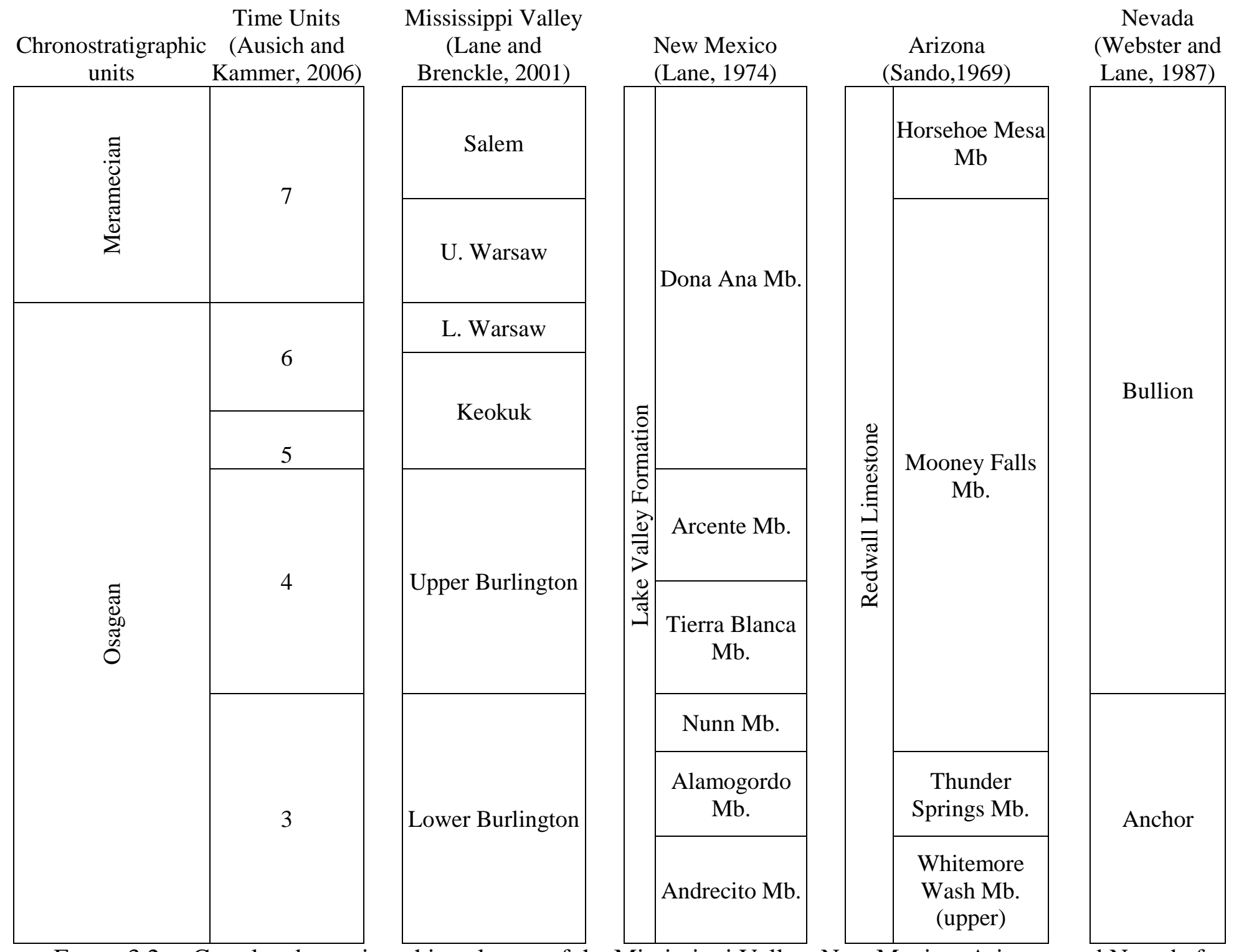

FIgURE 3.2.-Correlated stratrigraphic columns of the Mississippi Valley, New Mexico, Arizona, and Nevada formations for the Osagean and early Meramecian. 


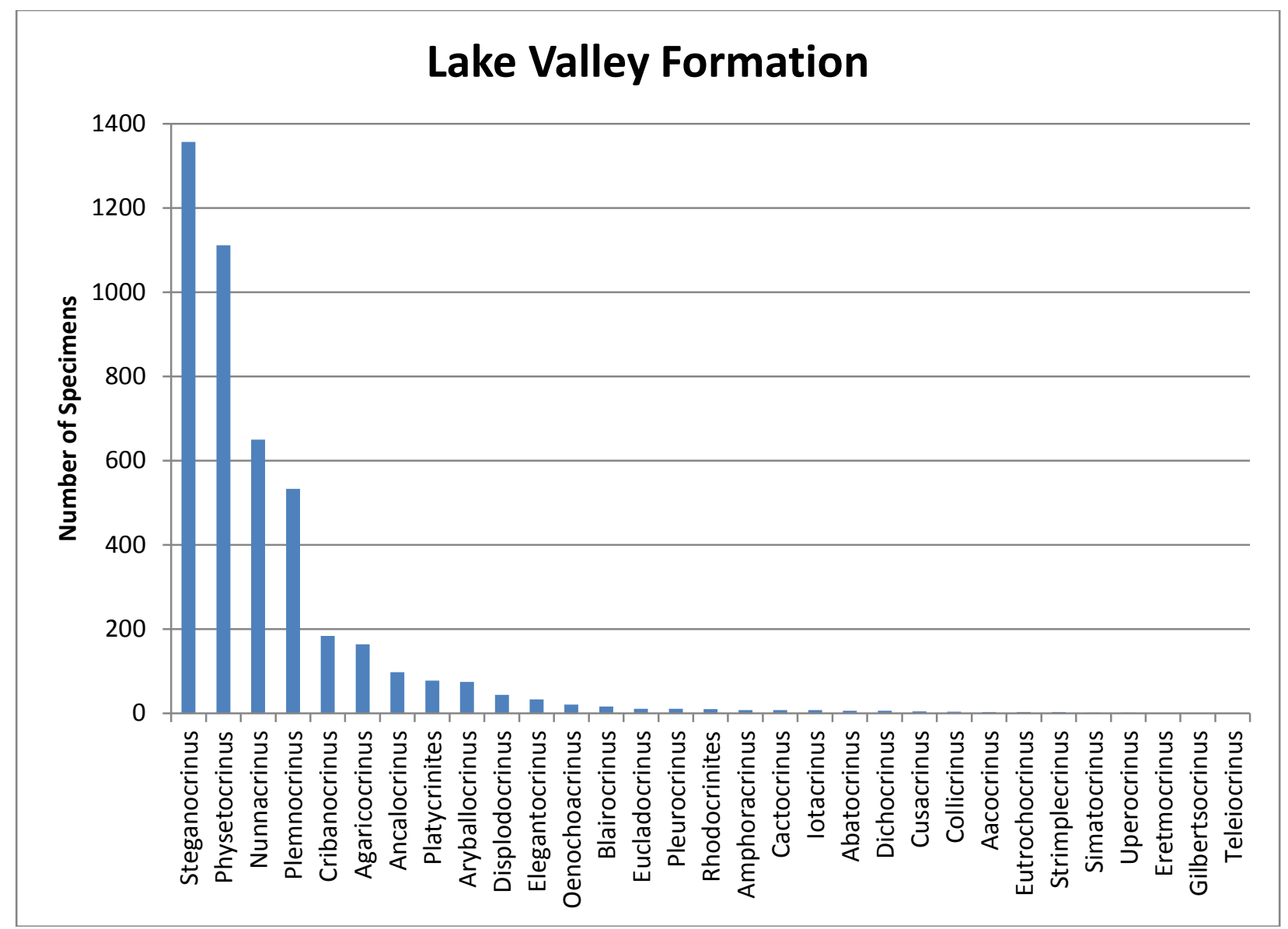




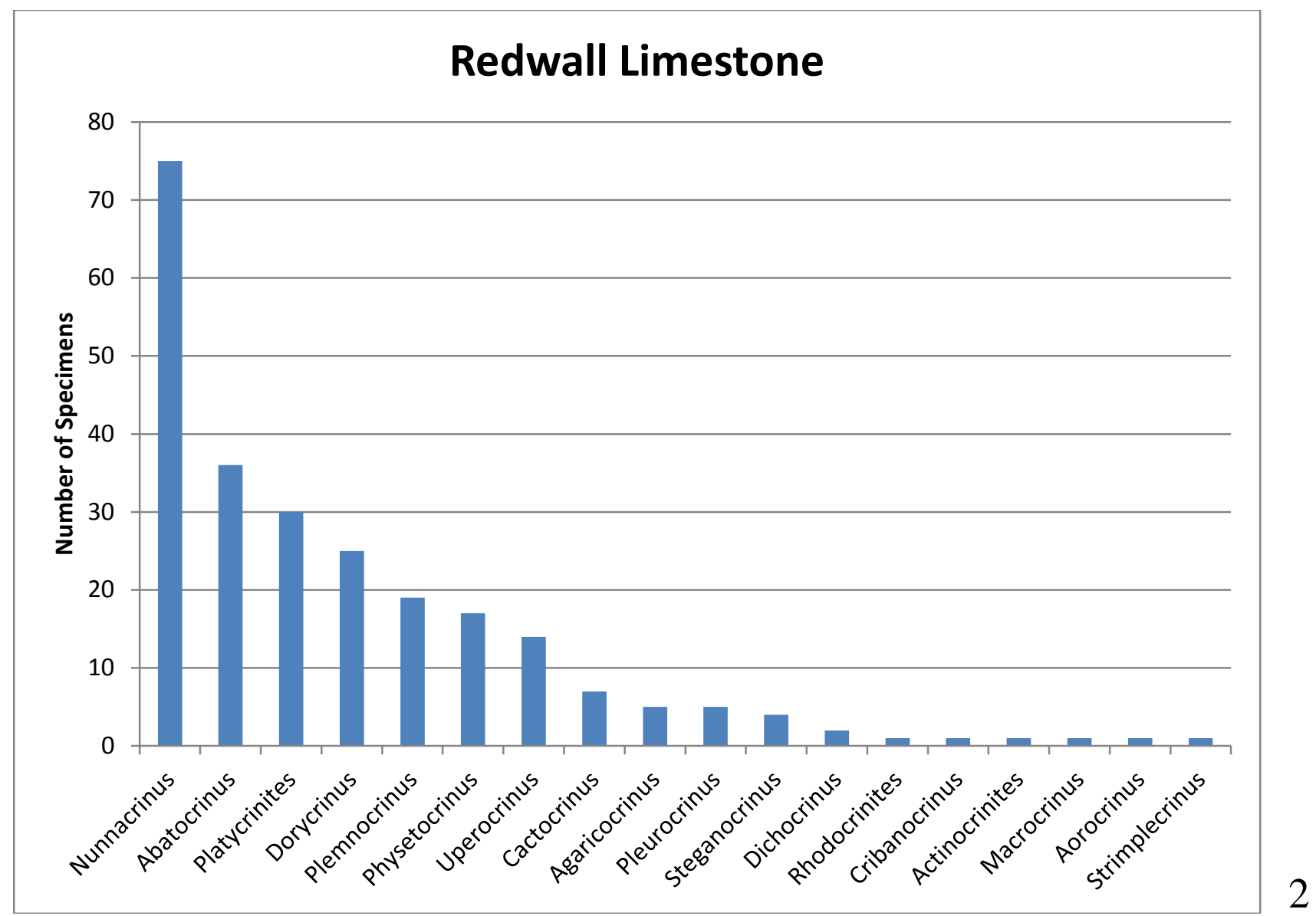




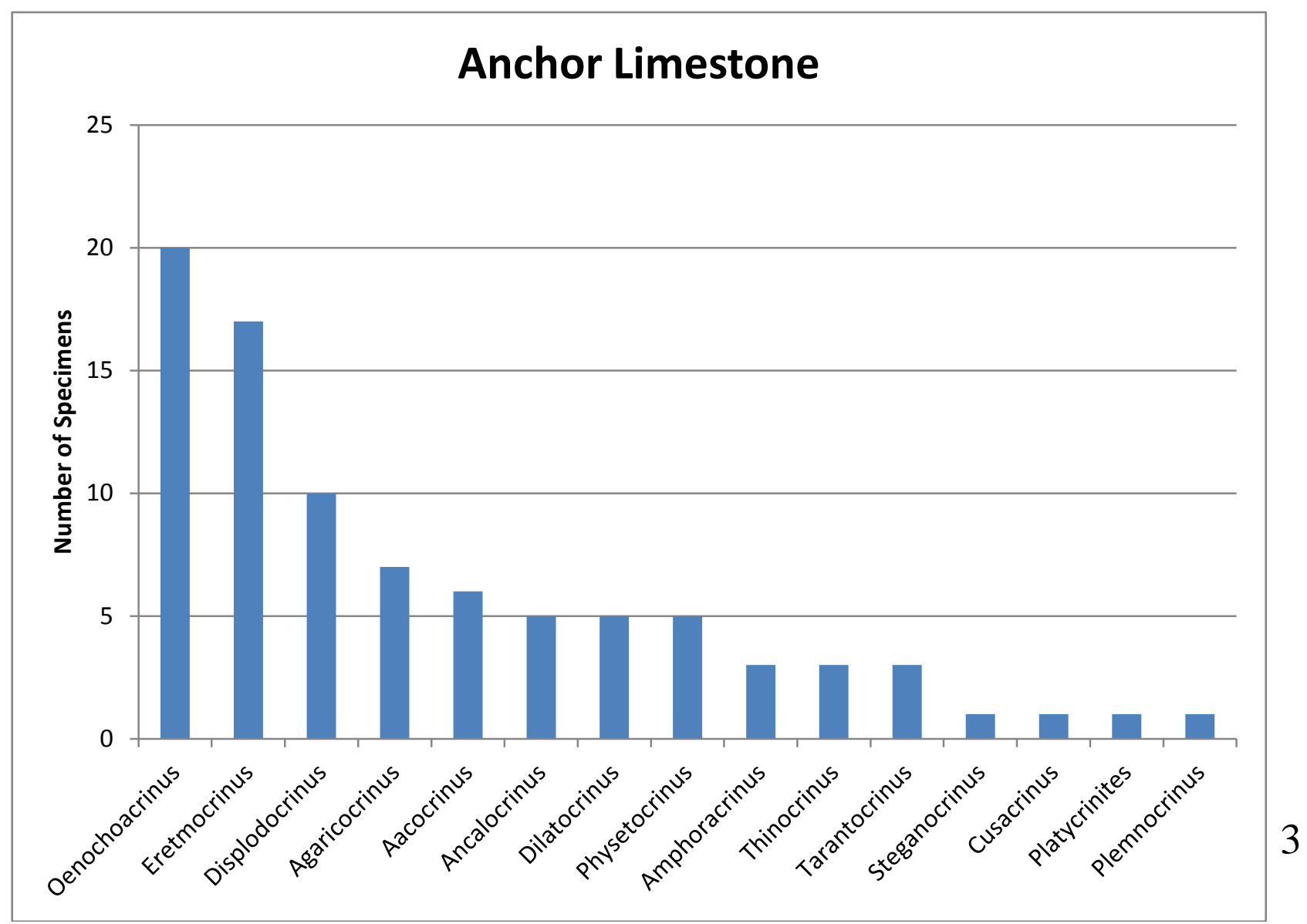




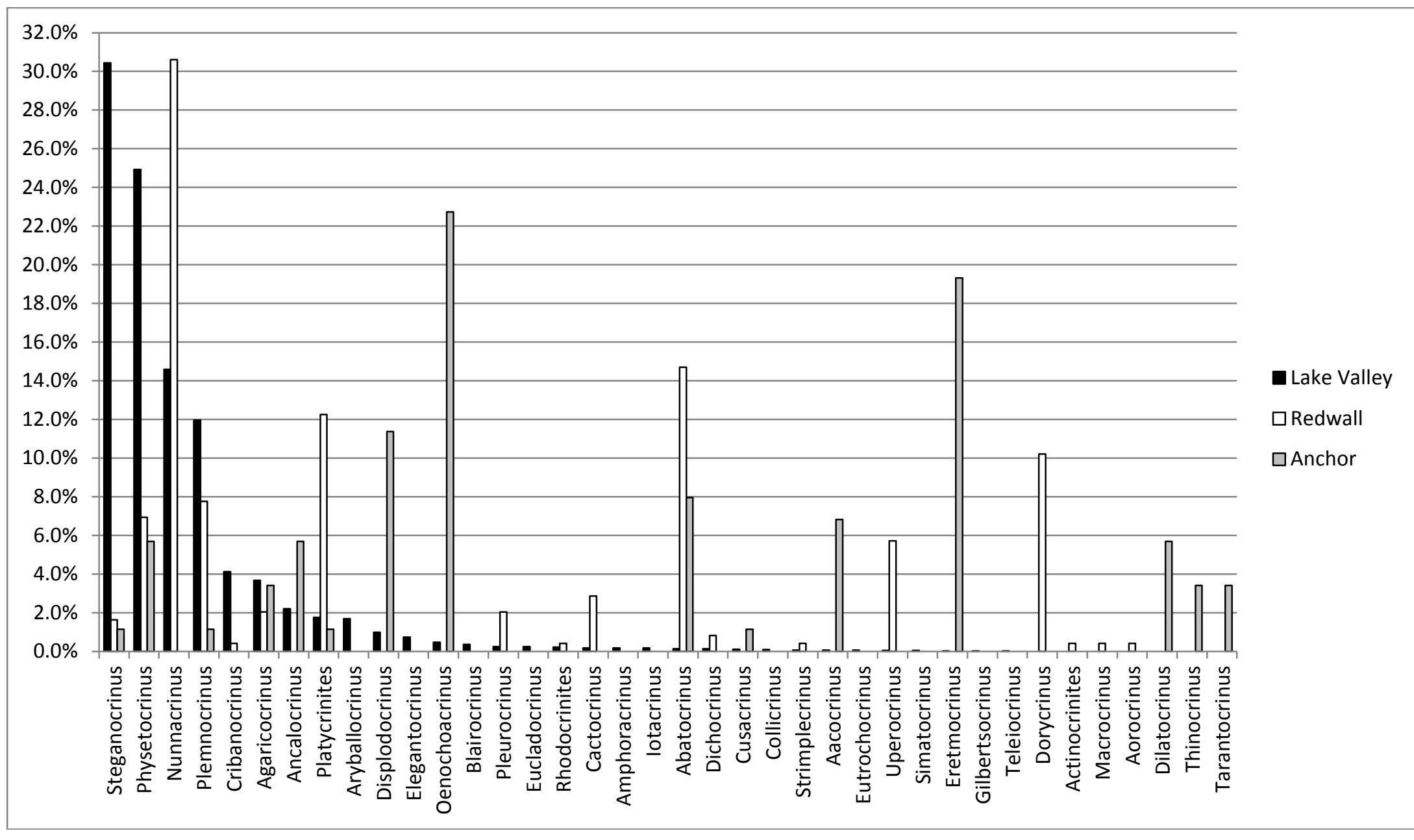

FIgURE 3.3.- Specimen counts for the Lake Valley, Redwall, and Anchor formations: 1) Nunn Member counts (Rhenberg and Kammer, ms), n=4457; 2) Thunder Springs and Mooney Falls member counts (Brower, 1969), n=245; 3) Anchor Limestone counts (Webster and Lane, 1987), n=88; 4) Percentages of camerates compared between the formations. 


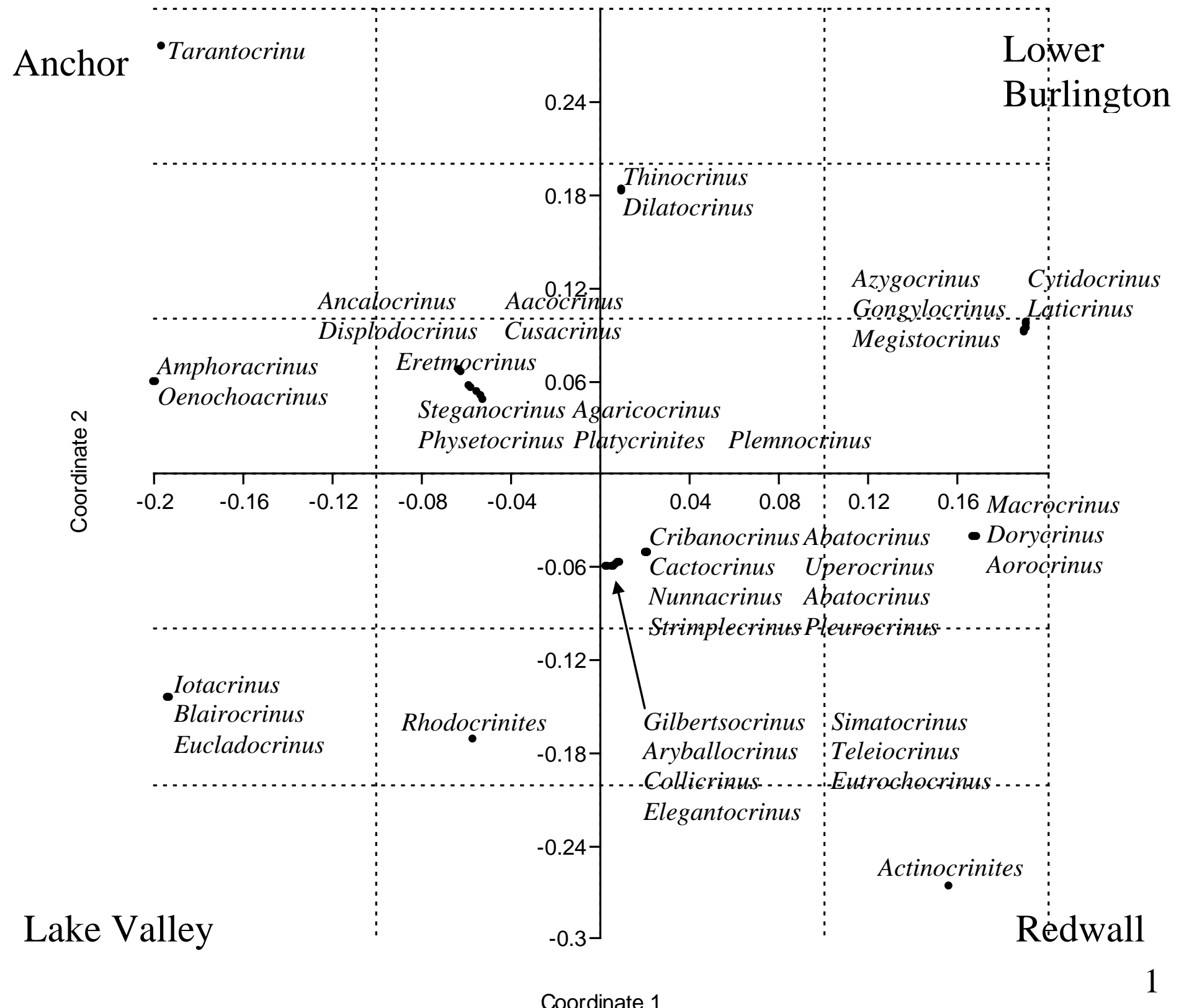




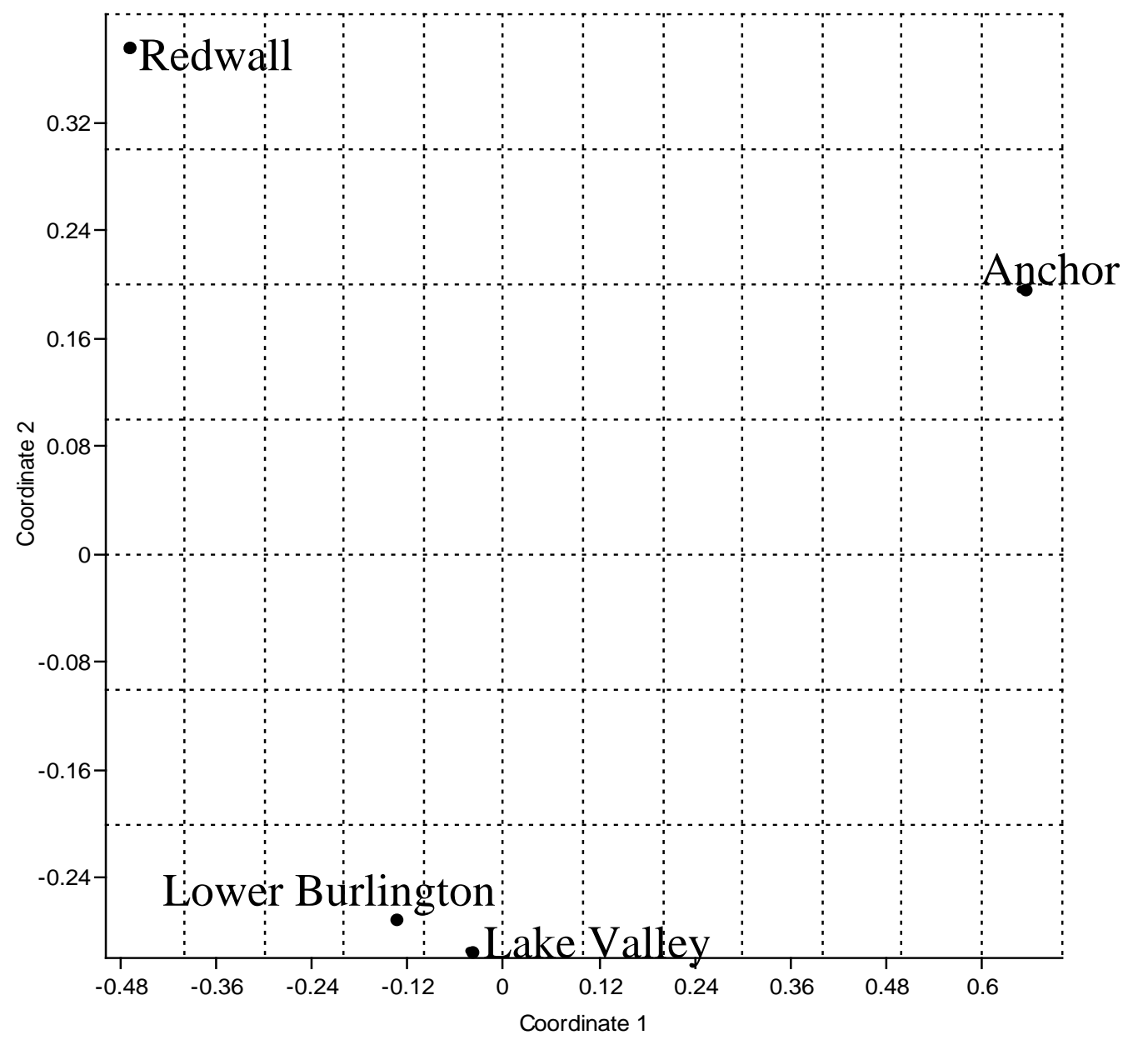

FiguRE 3.4.- Graphs based on the Jaccard Coefficient showing the similarity between the formations: 1) R-Mode MDS graph showing how camerate genera correlate to the formations. The genera unique to each formation are found at the farthest points away from the center in each quadrant; 2) Q-Mode MDS graph showing how the formations plot based on faunal similarity, or number of shared genera. The lower Burlington and Lake Valley formations plot closely to each other because of the greatest number of shared genera, whereas the Anchor and Redwall limestones plot on opposite ends. 


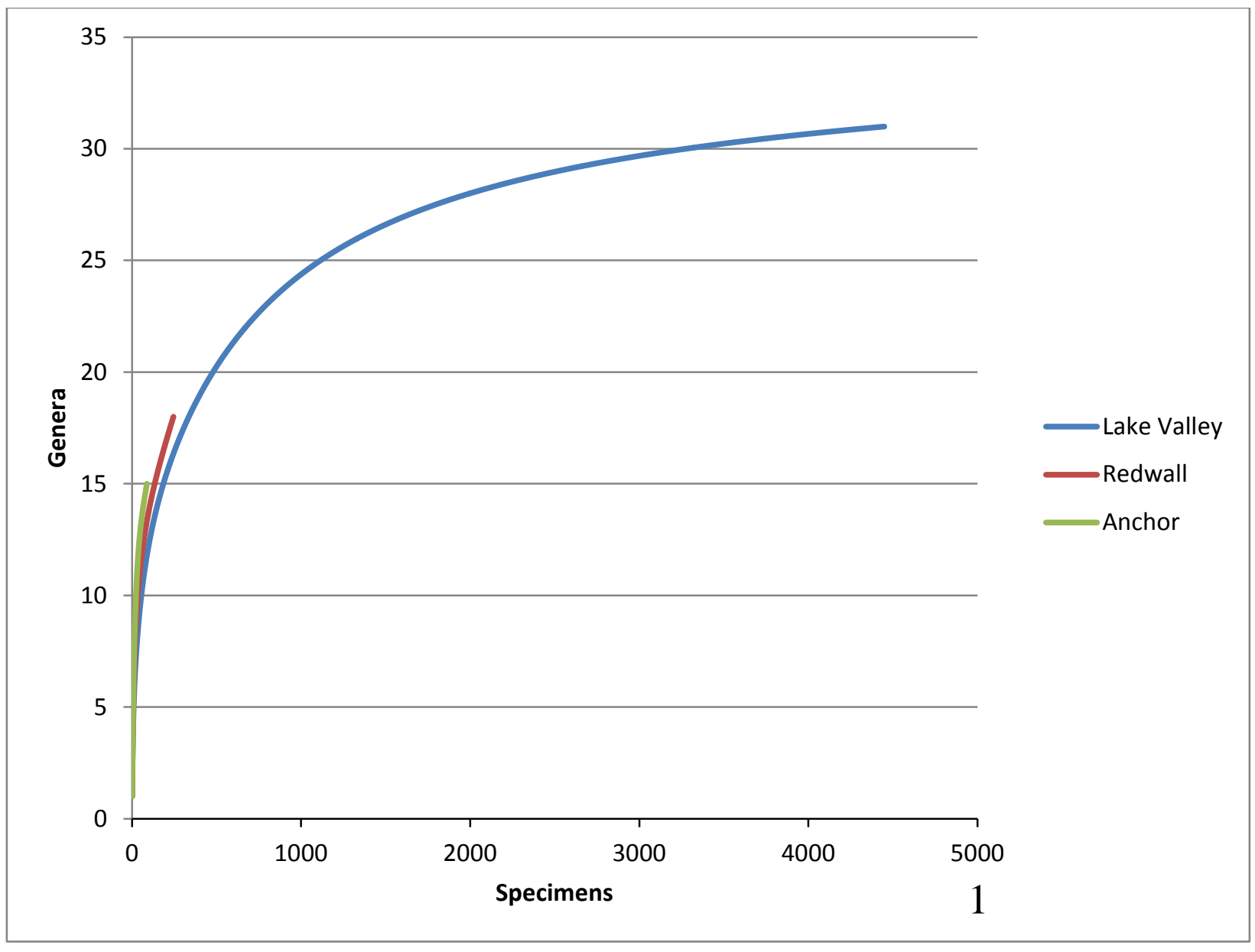




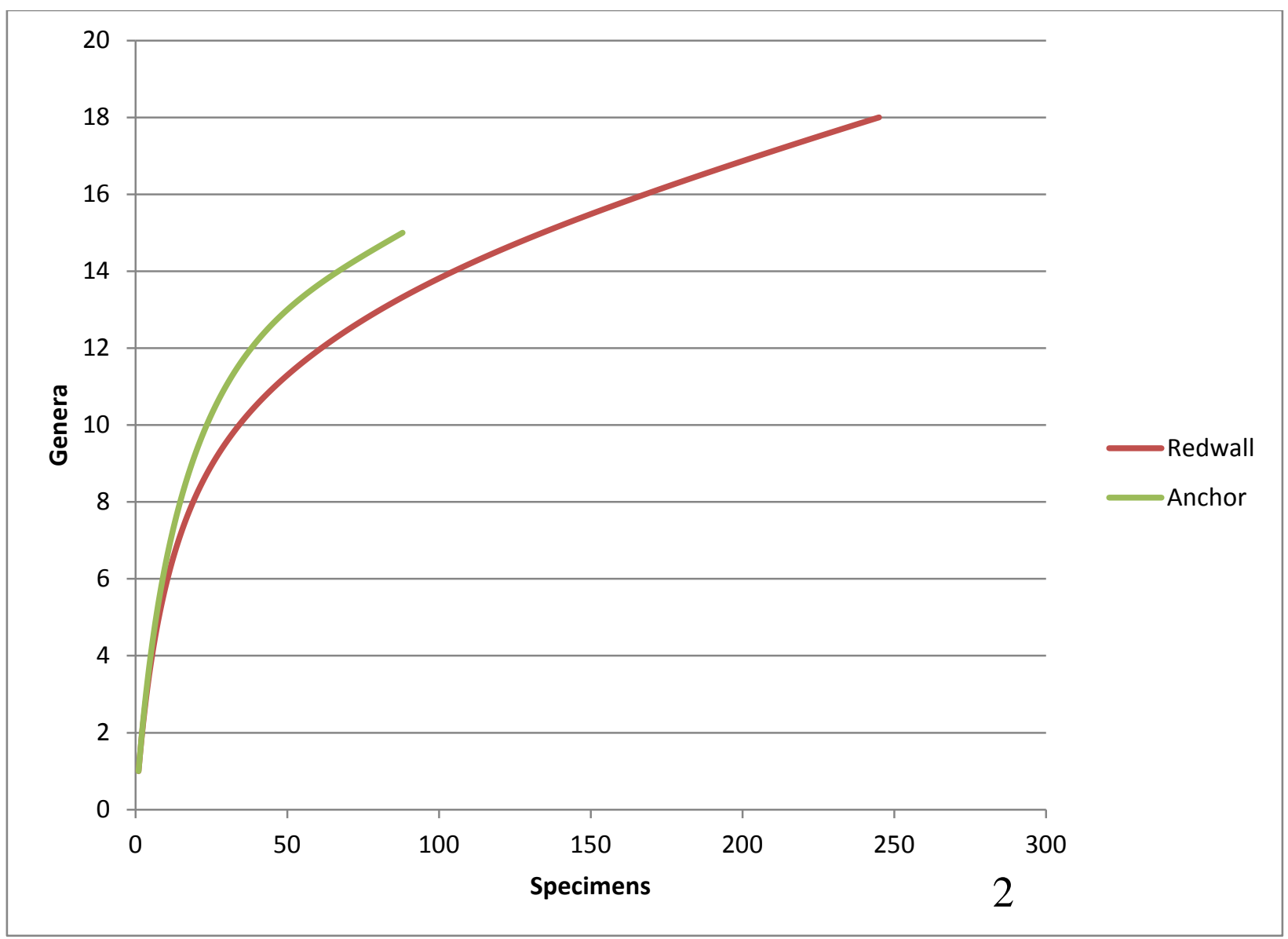




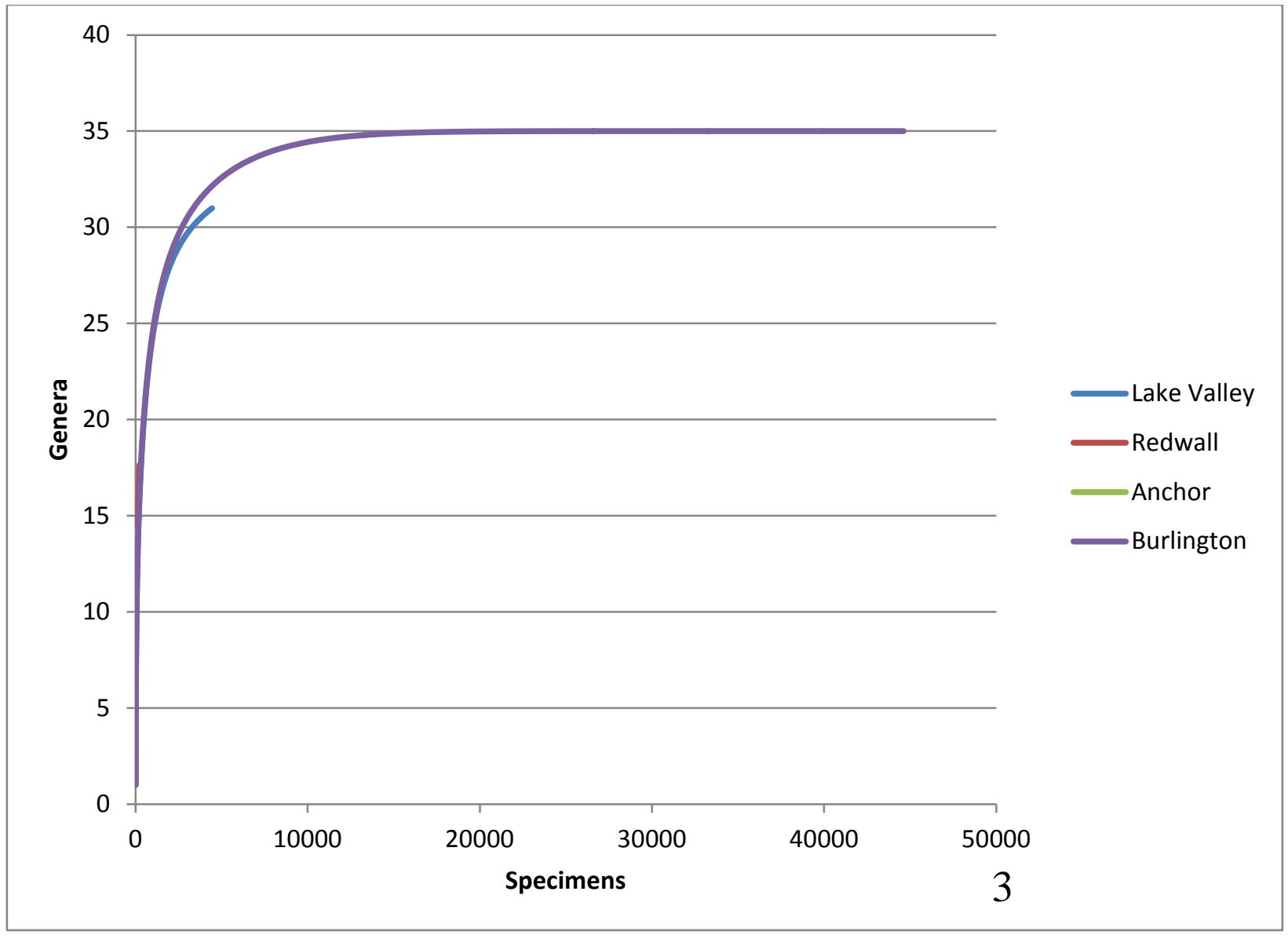

FIGURE 3.5.- Rarefaction curves indicating that the low generic richness of the Anchor and Redwall is due to low sample sizes: 1) Curve comparing the Redwall and Anchor to the Lake Valley; 2) Curve showing just the Redwall and Anchor; 3) Curve showing the lower Burlington modeled after the logarithmic decline of genera in the Lake Valley multiplied by ten. 
Appendix 1 - Locality information for collecting sites. M localities were collected by Dr. Macurda, Laudon numbers collected by Dr. Laudon, and FC localities were collected by the authors.

\begin{tabular}{lcl}
\hline \hline Year & Locality \# & \multicolumn{1}{c}{ Locality Name } \\
\hline 1970 & M-153 & 0 Bar 0 Canyon \\
1970 & M-154 & 0 Bar 0 Canyon \\
1970 & M-155 & 0 Bar 0 Canyon \\
1970 & M-149 & Apache Hill \\
1970 & M-150 & Apache Hill \\
1970 & M-152 & Apache Hill \\
1965 & M-86 & Apache Hill \\
1965 & M-87 & Apache Hill \\
1965 & M-89 & Apache Hill \\
1966 & M-15 & Black Range \\
1966 & M-16 & Black Range \\
1966 & M-17 & Black Range \\
1966 & M-18 & Black Range \\
1969 & M-18 & Black Range \\
1966 & M-19 & Black Range \\
1972 & M-7 & Black Range \\
1971 & M-91 & btw North Percha \& Mineral Creeks \\
1965 & M-101 & Cooks Range \\
1965 & M-102 & Cooks Range \\
1971 & M-97 & Cooks Range \\
1965 & M-80 & Deadman Canyon \\
1970 & M-176 & Indian Wells Canyon \\
1966 & M-6 & Indian Wells Canyon \\
1965 & M-69 & Indian Wells Canyon \\
1966 & M-7 & Indian Wells Canyon \\
1971 & M-80 & Indian Wells Canyon \\
1966 & M-9 & Indian Wells Canyon \\
1971 & M-92 & North Hollow Creek \\
1971 & M-93 & North Hollow Creek \\
1971 & M-94 & North Hollow Creek \\
1970 & M-158 & Percha Creek \\
1970 & M-159 & Percha Creek \\
1971 & M-100 & Percha Creek Fork \\
1971 & M-101 & Percha Creek Fork \\
1971 & M-98 & Percha Creek Fork \\
1971 & M-99 & Percha Creek Fork \\
1970 & M-157 & Rock Springs \\
1966 & M-21 & Rock Springs \\
1966 & M-22 & Rock Springs \\
1975 & M-73 & San Andres Canyon \\
1971 & M-102 & Santa Rita \\
1971 & M-103 & Santa Rita \\
\hline & M-8 & Santa Rita \\
1966 & Tierra Blanca Mt. \\
M-95 & Trujillo Creek \\
\hline 1972 - &
\end{tabular}




\begin{tabular}{|c|c|c|c|}
\hline Laudon \# & Locality Name & Laudon \# & Locality Name \\
\hline 13,579 & Alamo Canyon & 13,806 & Pryor Nunn Ranch \\
\hline 13,752 & Apache Hill & 13,824 & Pryor Nunn Ranch \\
\hline 13,779 & Apache Hill & 13,855 & Pryor Nunn Ranch \\
\hline 13,817 & Apache Hill & 13,986 & Pryor Nunn Ranch \\
\hline 13,863 & Apache Hill & 14,041 & Pryor Nunn Ranch \\
\hline 14,272 & Apache Hill & 14,042 & Pryor Nunn Ranch \\
\hline 14,052 & Berenda Canyon & 14,072 & Pryor Nunn Ranch \\
\hline 14,061 & Grapevine & 14,284 & Pryor Nunn Ranch \\
\hline 13,980 & Hillsboro & 14,290 & Pryor Nunn Ranch \\
\hline 13,754 & Indian Wells Canyon & 13,743 & San Andres Canyon \\
\hline 13,760 & Indian Wells Canyon & 13,750 & Unknown \\
\hline 13,763 & Indian Wells Canyon & 13,755 & Unknown \\
\hline 13,777 & Indian Wells Canyon & 13,757 & Unknown \\
\hline 13,778 & Indian Wells Canyon & 13,766 & Unknown \\
\hline 13,834 & Indian Wells Canyon & 13,769 & Unknown \\
\hline 13,836 & Indian Wells Canyon & 13,775 & Unknown \\
\hline 13,838 & Indian Wells Canyon & 13,781 & Unknown \\
\hline 13,784 & Lake Valley & 13,785 & Unknown \\
\hline 13,966 & Lake Valley & no \# & Unknown \\
\hline 13,509 & Marble Canyon & 13,765 & Wittenberg Ranch Windmill Section \\
\hline 13,551 & Marble Canyon & 13,768 & Wittenberg Ranch Windmill Section \\
\hline 13,552 & Marble Canyon & 13,803 & Wittenberg Ranch Windmill Section \\
\hline 13,553 & Marble Canyon & 13,825 & Wittenberg Ranch Windmill Section \\
\hline 13,557 & Marble Canyon & 13,833 & Wittenberg Ranch Windmill Section \\
\hline 13,567 & Marble Canyon & 13,905 & Wittenberg Ranch Windmill Section \\
\hline 13,569 & Marble Canyon & 13,918 & Wittenberg Ranch Windmill Section \\
\hline 13,572 & Marble Canyon & 13,923 & Wittenberg Ranch Windmill Section \\
\hline 13,578 & Marble Canyon & 13,929 & Wittenberg Ranch Windmill Section \\
\hline 13,611 & Marble Canyon & 13,932 & Wittenberg Ranch Windmill Section \\
\hline 13,619 & Marble Canyon & 13,964 & Wittenberg Ranch Windmill Section \\
\hline 13,822 & Marble Canyon & 13,997 & Wittenberg Ranch Windmill Section \\
\hline 14,028 & Marble Canyon & 13,998 & Wittenberg Ranch Windmill Section \\
\hline 14,031 & Marble Canyon & 13,999 & Wittenberg Ranch Windmill Section \\
\hline 14,077 & Marble Canyon & 14,006 & Wittenberg Ranch Windmill Section \\
\hline 14,088 & Marble Canyon & 14,022 & Wittenberg Ranch Windmill Section \\
\hline 14,249 & Marble Canyon & 14,025 & Wittenberg Ranch Windmill Section \\
\hline 14,250 & Marble Canyon & 14,030 & Wittenberg Ranch Windmill Section \\
\hline 14,260 & Marble Canyon & 14,059 & Wittenberg Ranch Windmill Section \\
\hline 14,261 & Marble Canyon & 14,062 & Wittenberg Ranch Windmill Section \\
\hline 13,727 & Pryor Nunn Ranch & 14,065 & Wittenberg Ranch Windmill Section \\
\hline 13,763 & Pryor Nunn Ranch & & \\
\hline
\end{tabular}

\begin{tabular}{cl}
\hline \hline Locality \# & \multicolumn{1}{c}{ Locality Name } \\
\hline FC1 & Apache Hill \\
FC2 & Percha Creek Fork \\
FC3 & North Percha Creek \\
\hline
\end{tabular}


Appendix 2 - Township and range information for the Macurda localities.

\begin{tabular}{|c|c|c|c|c|c|}
\hline Year & Locality \# & County & Quad & Locality Name & Township and Range \\
\hline 1965 & M-69 & & & & West half of sec. 14 , T16S, R10E \\
\hline 1965 & M-80 & & & Deadman Canyon & $\mathrm{NW}^{1} / 4 \mathrm{SE}^{1} / 4$ sec. 3 , T17S, R10E \\
\hline 1965 & M-86 & & Lake Valley & Apache Hill & SE1/4 sec. $16, \mathrm{~T} 18 \mathrm{~S}, \mathrm{R} 7 \mathrm{~W}$ \\
\hline 1965 & M-87 & & Lake Valley & Apache Hill & SE1/4 sec. $16, \mathrm{~T} 18 \mathrm{~S}, \mathrm{R} 7 \mathrm{~W}$ \\
\hline 1965 & M-89 & & Lake Valley & Apache Hill & $\mathrm{SE}^{1} / 4$ sec. $16, \mathrm{~T} 18 \mathrm{~S}, \mathrm{R} 7 \mathrm{~W}$ \\
\hline 1965 & M-95 & Sierra & & Tierra Blanca Canyon & SW1/4NW1/4 sec. 10 , T17S, R8W \\
\hline 1965 & M-101 & Luna & Lake Valley & Cooks & $\mathrm{S}^{1} / 2 \mathrm{NW}^{1} 1 / 4 \& \mathrm{~N}^{1} / 2 \mathrm{SW}^{1} / 4$ of SW $1 / 4$ sec. 13 , T20S, R9W \\
\hline 1965 & M-102 & & & North Cooks & NW1/4 sec. 13 , T20S, R9W \\
\hline 1966 & M-6 & Otero & & & SE$^{1} / 4 \mathrm{SW}^{1} / 4 \mathrm{SW}^{1} / 4$ sec. $11, \mathrm{~T} 16 \mathrm{~S}, \mathrm{R} 10 \mathrm{E}$ \\
\hline 1966 & M-7 & Otero & & Indian Wells Canyon & 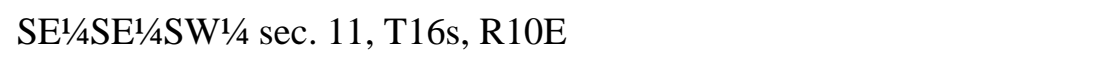 \\
\hline 1966 & M-9 & Otero & & Indian Wells Canyon & $\mathrm{NW}^{1} 1 / 4 \mathrm{NW}^{1} / 4 \mathrm{NW}^{1} / 4$ sec. 1 , T16S, R10E \\
\hline 1966 & M-13 & Sierra & Hillsboro & Tierra Blanca Canyon & SW1/4NW1/4 sec. 10 , T17S, R8W \\
\hline 1966 & M-15 & Sierra & Hillsboro & & $\mathrm{NE}^{1 / 4} \mathrm{NE}^{1 / 4} \mathrm{NE}^{1 / 4} \mathrm{NW}^{1} / 4$ sec. $22, \mathrm{~T} 17 \mathrm{~S}, \mathrm{R} 8 \mathrm{~W}$ \\
\hline 1966 & M-16 & Sierra & Hillsboro & & $\mathrm{SW}^{1 / 4} \mathrm{NE}^{1 / 4} \mathrm{NE}^{1} / 4 \mathrm{NW}^{1} / 4$ sec. 22 , T17S, R8W \\
\hline 1966 & M-17 & Sierra & Hillsboro & PA Mountain & NW11/4NW1/4SW1/4 sec. 26, T17S, R8W \\
\hline 1966 & M-18 & Sierra & Hillsboro & PA Canyon & C NW11/4SE1/4 sec. 26, T17S, R8W \\
\hline 1966 & M-19 & Sierra & Hillsboro & PA Mountain & C NE1/4 sec. 34, T17S, R8W \\
\hline 1966 & M-21 & Sierra & Hillsboro & Rock Springs & $\mathrm{SE}^{1} / 4 \mathrm{SW}^{1} / 4 \mathrm{NW}^{1} / 4$ sec. $28, \mathrm{~T} 16 \mathrm{~S}, \mathrm{R} 8 \mathrm{~W}$ \\
\hline 1966 & M-22 & Sierra & Hillsboro & Rock Springs & C N1/2NW1/4 sec. 28 , T16S, R8W \\
\hline 1969 & M-18 & Sierra & Hillsboro & & $\mathrm{NW}^{1} 1 / 4 \mathrm{SW}^{1} 1 / 4 \mathrm{SE}^{1} / 4 \mathrm{NW}^{1} / 4$ sec. 33, T16S, R8W \\
\hline 1970 & M-149 & Sierra & Lake Valley & Apache Hill & $\mathrm{SW}^{1 / 4}$ \& SE $1 / 4$ of NW1/4 sec. $21, \mathrm{~T} 18 \mathrm{~S}, \mathrm{R} 7 \mathrm{~W}$ \\
\hline 1970 & M-150 & Sierra & Lake Valley & Apache Hill & $\mathrm{C} \mathrm{N}^{1} \frac{1}{2}$ line btw NW $1 / 4 \mathrm{NE}^{1 / 4}$ \& NE $1 / 4 \mathrm{NW}^{1} / 4$ of $\mathrm{SW}^{1} / 4$ sec. 21 , T18S, R7W \\
\hline 1970 & M-151 & Sierra & Lake Valley & Apache Hill & C line btw NW11/4 \& NE1/4 of NE1/4SW1/4 sec. 21, T18S, R7W \\
\hline 1970 & M-152 & Sierra & Lake Valley & Apache Hill & $\mathrm{NE}^{1 / 4} \mathrm{SE}^{1} / 4 \mathrm{NE}^{1 / 4} \mathrm{SW}^{1} / 4$ sec. $21, \mathrm{~T} 18 \mathrm{~S}, \mathrm{R} 7 \mathrm{~W}$ \\
\hline 1970 & M-153 & Sierra & Hillsboro & 0 Bar 0 Canyon & C SW $1 / 4 \mathrm{SW}^{1 / 4}$ sec. $35, \mathrm{~T} 17 \mathrm{~S}, \mathrm{R} 8 \mathrm{~W}$ \\
\hline 1970 & M-154 & Sierra & Hillsboro & 0 Bar 0 Canyon & C N1/2SW1/4SW1/4SW1/4 sec. 35, T17S, R8W \\
\hline 1970 & M-155 & Sierra & Hillsboro & 0 Bar 0 Canyon & $\mathrm{NW}^{1} / 4 \mathrm{SE}^{1 / 4} \mathrm{SE}^{1 / 4} \mathrm{SE} \mathrm{S}^{1 / 4}$ sec. $34, \mathrm{~T} 17 \mathrm{~S}, \mathrm{R} 8 \mathrm{~W}$ \\
\hline 1970 & M-157 & Sierra & Hillsboro & Rock Springs & $\mathrm{SE}^{1 / 4} \mathrm{SE}^{1 / 4} \mathrm{NW}^{1} / 4$ sec. $28, \mathrm{~T} 16 \mathrm{~S}, \mathrm{R} 8 \mathrm{~W}$ \\
\hline
\end{tabular}




\begin{tabular}{|c|c|c|c|c|c|}
\hline Year & Locality \# & County & Quad & Locality Name & Township and Range \\
\hline 1970 & M-158 & Sierra & Hillsboro & & $\mathrm{C} \mathrm{NW}^{1} 1 / 4 \mathrm{SW}^{1} 1 / 4 \mathrm{SE}^{1} / 4$ sec. $14, \mathrm{~T} 16 \mathrm{~S}, \mathrm{R} 7 \mathrm{~W}$ \\
\hline 1970 & M-159 & Sierra & Hillsboro & Percha Creek & $\mathrm{C} \mathrm{E}^{1 / 2} \mathrm{NE}^{1 / 4} \mathrm{NW}^{1 / 1} / 4 \mathrm{SE}^{1} / 4$ sec. $14, \mathrm{~T} 16 \mathrm{~S}, \mathrm{R} 7 \mathrm{~W}$ \\
\hline 1970 & M-176 & Otero & Alamogordo & Indian Wells Canyon & $\mathrm{C} \mathrm{SE}^{1} / 4 \mathrm{SW}^{1} 1 / 4$ sec. 11 to SW1/4SW1/4SE1/4 sec. 11 , T16S, R10E \\
\hline 1971 & M-80 & Otero & Alamogordo & Indian Wells Canyon & $\mathrm{SE}^{1 / 4} \mathrm{SE}^{1 / 4} \mathrm{SW}^{1 / 1} / 4$ sec. 11 to SW1/4SW1/4SE1/4 sec. $11, \mathrm{~T} 16 \mathrm{~S}, \mathrm{R} 10 \mathrm{E}$ \\
\hline 1971 & M-91 & Sierra & Hillsboro & btw North Percha \& Mineral Creeks & 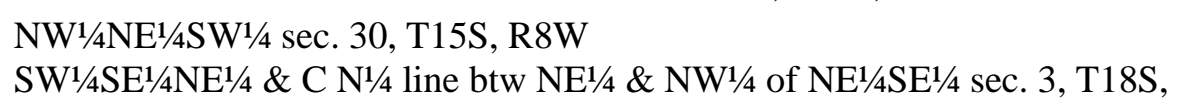 \\
\hline 1971 & M-92 & Sierra & Hillsboro & & R8W \\
\hline 1971 & M-93 & Sierra & Hillsboro & & C line btw SE1/4NE1/4 \& NE1/4SE1/4 of SE1/4 sec. 3, T18S, R8W \\
\hline 1971 & M-94 & Sierra & Hillsboro & North Hollow Creek & $\mathrm{C} \mathrm{E}^{1 / 2} \mathrm{NW}^{1 / 4} \mathrm{NW}^{1 / 1} / 4 \mathrm{SE}^{1} / 4$ sec. 3 , T18S, R8W \\
\hline 1971 & M-97 & Sierra & Lake Valley & & $\mathrm{S}^{1 / 2} \mathrm{NW}^{1 / 1} / 4$ of $\mathrm{NE}^{1 / 4} \mathrm{NW}^{1 / 4} \mathrm{sec}$. 24 , T20S R9W \\
\hline 1971 & M-98 & Sierra & Hillsboro & Middle Percha Creek & $\mathrm{NE}^{1 / 4} \mathrm{NW}^{1 / 1} / 4 \mathrm{NE}^{1 / 4}$ sec. 16 , T16S, R8W \\
\hline 1971 & M-99 & Sierra & Hillsboro & & $\mathrm{NW}^{1} 1 / 4 \mathrm{NW}^{1} / 4 \mathrm{SW}^{1} 1 / 4 \mathrm{NE}^{1 / 4} / 4$ sec. $16, \mathrm{~T} 16 \mathrm{~S}, \mathrm{R} 8 \mathrm{~W}$ \\
\hline 1971 & M-100 & Sierra & Hillsboro & & $\mathrm{SE}^{1 / 4}$ thru SW1/4 of NE $1 / 4$ to NE1/4SW1/4 of SE $1 / 4$ sec. $16, \mathrm{~T} 16 \mathrm{~S}, \mathrm{R} 8 \mathrm{~W}$ \\
\hline 1971 & M-101 & Sierra & Hillsboro & South Percha Creek & 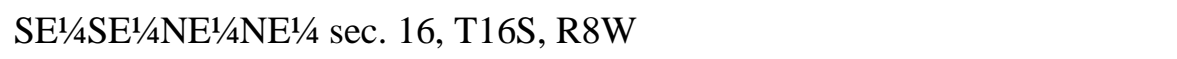 \\
\hline 1971 & M-102 & Grant & Santa Rita & & $\mathrm{C} \mathrm{E}^{1 / 2} \mathrm{SW}^{1 / 1} / 4 \mathrm{NW}^{1} / 4$ sec. 7 , T17S, R11W \\
\hline 1971 & M-103 & Grant & Santa Rita & & $\mathrm{NW}^{1 / 1} / 4 \mathrm{NW}^{1 / 1} / 4 \mathrm{NW}^{1} 1 / 4 \mathrm{SE}^{1} / 4 \mathrm{NW}^{1} / 4$ sec. $7, \mathrm{~T} 17 \mathrm{~S}, \mathrm{R} 11 \mathrm{~W}$ \\
\hline 1972 & M-5 & Sierra & Hillsboro & & $\begin{array}{l}\text { C line btw NE1/4 \& NW11/4 sec. 26, T16S, R7W } \\
\text { C line btw SW1/4 \& SE1/4 of NW11/4 to NW1/2NE1/4SW1/4SW1/4 sec. 15, T17S, }\end{array}$ \\
\hline 1972 & M-7 & Sierra & Hillsboro & & R8W \\
\hline 1972 & M-8 & Grant & Santa Rita & & $\mathrm{SW}^{1 / 4} \mathrm{NW}^{1} 1 / 4 \mathrm{SW} 1 / 4$ sec. 6 , T17S, R11W \\
\hline 1975 & M-73 & Dona Ana & Bear Peak & San Andres Canyon & $\mathrm{CN}^{1} 1 / 2 \mathrm{SE}^{1} / 4 \mathrm{SE}^{1} / 4 \mathrm{SE}^{1} / 4 \mathrm{NE}^{1} / 4$ sec. 18 and NW1/4SW1/4NW1/4 sec. 17 , T18S, R4E \\
\hline
\end{tabular}


ApPendix 3 - Interradial plate counts of all Nunnacrinus dalyanus studied, including the type specimens of Nunnacrinus mammillatus from the Smithsonian Institution.

\begin{tabular}{|c|c|c|c|c|c|c|}
\hline Locality & Specimen \# & A-B & B-C & C-D & D-E & E-A \\
\hline M-005-1 & 1 & $1,2,1,2$ & - & - & - & - \\
\hline M-006-2 & 1 & $1,2,1,2$ & $1,2,1,1$ & - & - & - \\
\hline M-006-2 & 2 & $1,2,1,1$ & $1,2,1,1$ & $1,2,3,2$ & $1,2,1,1$ & $1,2,1 . ?$ \\
\hline M-006-2 & 4 & $1,2,1$ & $1,2 ?, 1 ?$ & $1,2,1 ?, 1$ & $1,2,1,1$ & $1,2,1,1$ \\
\hline M-006-2 & 3 & $1,2,2, ?$ & $1,2,2,2$ & $1,2,3 ?, 1 ?, 1 ?$ & $1,2,2,1,2$ & $1,2,2,1, ?$ \\
\hline M-007-11 & 1 & - & - & - & - & - \\
\hline M-007-12 & 1 & - & - & $1,2, ?$ & - & - \\
\hline M-007-16 & 1 & $1,2,2,1$ & - & - & - & - \\
\hline M-009-2 & 2 & - & $1,1,1$ & $1,2,1,1$ & - & - \\
\hline M-009-2 & 1 & - & - & - & - & - \\
\hline M-013-05 & 4 & - & - & $1,2,3,1$ & $1,2,1,1$ & $1,2,1,1$ \\
\hline M-013-05 & 1 & $1,2,2,2$ & $1,2,2,2$ & $1,2,2,2,2$ & $1,2, ?$ & $1,2,2, ?$ \\
\hline M-013-05 & 2 & $1,2,2, ?$ & $1,2,2, ?$ & $1,2,3,2$ & $1,2, ?$ & $1,2, ?$ \\
\hline M-013-05 & 3 & $1,1,2,2,2,1$ & $1,2, ?$ & $1,2,2,3,1$ & $1,2,1,2$ & $1,2,2,1$ \\
\hline M-013-11 & 3 & $1,2, ?, 1$ & $1,2,2, ?$ & $1,2,2,1,2$ & $1,2,1$ & $1,2, ?, 1$ \\
\hline M-013-11 & 2 & - & $1,2,2, ?$ & $1,2,3,2,1$ & $1,2, ?$ & $1,2,2,2$ \\
\hline M-013-11 & 1 & - & - & - & - & - \\
\hline M-013-13 & 1 & $1,2,2,1$ & 1,2,?,1 & $1,3,3,1$ & 1,2,?,1 & $1,2,2,1$ \\
\hline M-013-13 & 2 & $1,2,2,1$ & $1,2,2,1$ & $1,2,2,1,1$ & - & $1,2, ?$ \\
\hline M-013-13 & 3 & - & - & - & - & - \\
\hline M-015-10 & 1 & - & $1,2, ?$ & $1,2,2,1$ & $1,2,2,1$ & - \\
\hline M-015-10 & 2 & $1,2, ?$ & $1,2,2,1$ & $1,2,2,1$ & $1,2,2,1$ & $1,2, ?, 1$ \\
\hline M-015-10 & 3 & $1,2,2$ & $1,2, ?$ & $1,2,2,1$ & - & $1,2,2$ \\
\hline M-015-10 & 5 & $1,2,2,1$ & $1,2,1$ & $1,2,2,1$ & $1,2,1$ & $1,2, ?, 1$ \\
\hline M-015-10 & 8 & $1,2,2,1$ & $1,2, ?$ & 1,2,3,?,2 & $1,2, ?, 1$ & $1,2, ?, 1$ \\
\hline M-015-10 & 4 & $1,2, ?, 1$ & $1,2,2,2$ & $1,2,3,2$ & $1,2,2,2$ & $1,2,2,2$ \\
\hline M-015-10 & 6 & $1,2,2$ & $1,2,2$ & $1,2, ?, 3$ & $1,2,2$ & $1,2,2$ \\
\hline M-015-10 & 7 & $1,2,2,2$ & $1,2,2,2$ & $1,2,3,1,2$ & $1,2,2,2$ & $1,2,2,2$ \\
\hline M-015-10 & 9 & $1,2,2,1$ & - & - & - & $1,2, ?$ \\
\hline M-015-15 & 1 & $1,2,2,1$ & $1,2,2,1$ & 1,2,?,?,3 & $1,2, ?, 1$ & $1,2, ?, 1$ \\
\hline M-015-15 & 2 & $1,2,2,1$ & $1,2,2,1$ & $1,2, ?$ & - & $1,2,2, ?$ \\
\hline M-015-15 & 3 & - & - & - & - & - \\
\hline M-015-15 & 4 & - & - & - & - & - \\
\hline M-015-15 & 5 & - & - & - & - & - \\
\hline M-015-33 & 1 & 1,2,?,1 & $1,2,2,1$ & $1,2,3,1$ & $1,2,2,1$ & $1,2, ?, 1$ \\
\hline M-015-33 & 2 & $1,2,2,1$ & $1,2,2,1$ & $1,2,2, ?, 1$ & $1,2,2,1$ & $1,2,2,1$ \\
\hline M-015-33 & 3 & $1,2,2,1$ & $1,2,2, ?, 2$ & 1,2,3,? & $1,2,2,1$ & - \\
\hline M-015-33 & 4 & $1,2,2,1$ & $1,2, ?, 1$ & $1,2, ?$ & - & $1,2, ?$ \\
\hline
\end{tabular}




\begin{tabular}{|c|c|c|c|c|c|c|}
\hline Locality & Specimen \# & A-B & $\mathrm{B}-\mathrm{C}$ & C-D & D-E & E-A \\
\hline M-015-33 & 5 & $1,2,2, ?, 1$ & $1,2,2,1$ & $1,2, ?, 1$ & $1,2,2,1,1$ & - \\
\hline M-015-33 & 6 & $1,2,1,1$ & $1,2,2,1$ & $1,2,1,1$ & $1,2,1,1$ & $1,2,2,1$ \\
\hline M-015-33 & 7 & - & $1,2,1$ & $1,2,1,1$ & $1,2,1$ & - \\
\hline M-015-33 & 8 & $1,2,1,1$ & $1,2,1,1$ & - & - & $1,2,1,1$ \\
\hline M-015-33 & 10 & $1,2, ?$ & $1,2, ?, 1$ & $1,2, ?, 1$ & $1,2,1,1$ & - \\
\hline M-015-33 & 9 & $1,2, ?$ & $1,2, ?$ & $1,2, ?$ & - & - \\
\hline M-015-33 & 11 & - & - & - & - & - \\
\hline M-015-33 & 12 & - & - & - & - & - \\
\hline M-015-33 & 13 & - & - & - & - & - \\
\hline M-015-33 & 14 & - & - & - & - & - \\
\hline M-015-45 & 4 & $1,2, ?, 1$ & $1,2, ?$ & $1,2,2,1$ & $1,2,1,1$ & $1,2,2,1$ \\
\hline M-015-45 & 6 & $1,2, ?, 1$ & $1,2, ?$ & 1,2,3,?,1 & - & - \\
\hline M-015-45 & 16 & $1,2,2,1$ & $1,2,2,2,1$ & $1,2,3, ?$ & $1,2,2,2$ & $1,2,2,2,1$ \\
\hline M-015-45 & 1 & $1,2,2,2,1,1$ & $1,2,2,2,1,1$ & $1,2,3,3,2,1,2$ & $1,2,2,2,1$ & $1,2,2,2,1,1$ \\
\hline M-015-45 & 8 & - & - & $1,2,3, ?, 2$ & $1,2,2,2$ & - \\
\hline M-015-45 & 9 & - & - & $1,2,3,2,2$ & $1,2,2,2$ & $1,2,2,2$ \\
\hline M-015-45 & 2 & $1,2, ?, 1$ & $1,2, ?$ & - & - & - \\
\hline M-015-45 & 3 & - & - & - & - & - \\
\hline M-015-45 & 5 & $1,2,2,1$ & - & - & - & - \\
\hline M-015-45 & 7 & - & - & - & - & - \\
\hline M-015-45 & 10 & - & - & - & - & - \\
\hline M-015-45 & 11 & $1,2,2,1$ & - & - & - & - \\
\hline M-015-45 & 12 & - & - & - & - & - \\
\hline M-015-45 & 13 & - & - & - & - & - \\
\hline M-015-45 & 14 & - & - & - & - & - \\
\hline M-015-45 & 15 & - & - & - & - & - \\
\hline M-015-45 & 17 & $1,2, ?, 2$ & - & - & - & - \\
\hline M-015-54 & 1 & - & $1,2,2, ?$ & $1,2, ?$ & $1,2,2,1,1$ & $1,2,2,1$ \\
\hline M-015-54 & 2 & $1,2,2, ?$ & - & $1,3, ?$ & $1,2,2,1$ & $1,2,2,1$ \\
\hline M-015-62 & 1 & 1,2,?,1 & - & 1,3,3,2 & 1,2,?,1 & $1,2,2,1$ \\
\hline M-015-62 & 2 & $1,2,2$ & $1,2, ?$ & $1,2,2, ?$ & - & - \\
\hline M-015-80 & 1 & $1,2, ?$ & $1,2, ?$ & $1,2,2,2$ & $1,2,2,1$ & $1,2,2, ?$ \\
\hline M-015-80 & 2 & $1,2,2,1$ & $1,2,2,1$ & $1,2,3,2,2$ & $1,2,2,1$ & $1,2,2,1$ \\
\hline M-015-80 & 4 & $1,2,2, ?$ & $1,2,1,1$ & $1,2, ?$ & - & $1,2,2,1$ \\
\hline M-015-80 & 14 & - & $1,2,1$ & $1,2,1,1$ & - & - \\
\hline M-015-80 & 9 & - & $1,2,2,2,1$ & $1,2, ?$ & - & $1,2,2,1,2$ \\
\hline M-015-80 & 11 & $1,2,2,2$ & $1,2,2,1$ & $1,2,2, ?$ & $1,2,2,2$ & $1,2,2,2$ \\
\hline M-015-80 & 3 & - & - & $1,2,3, ?, ?$ & $1,2, ?$ & - \\
\hline M-015-80 & 5 & $1,2,2,2$ & - & - & - & - \\
\hline M-015-80 & 6 & - & - & - & - & - \\
\hline M-015-80 & 7 & $1,2,2,1$ & $1,2,1$ & - & - & - \\
\hline
\end{tabular}




\begin{tabular}{|c|c|c|c|c|c|c|}
\hline Locality & Specimen \# & A-B & $\mathrm{B}-\mathrm{C}$ & C-D & D-E & E-A \\
\hline M-015-80 & 8 & - & - & - & - & - \\
\hline M-015-80 & 10 & $1,2, ?$ & $1,2, ?$ & $1,2, ?$ & - & $1,2, ?$ \\
\hline M-015-80 & 12 & - & $1,2,2, ?$ & $1,2, ?$ & - & - \\
\hline M-015-80 & 13 & - & - & - & - & - \\
\hline M-015-80 & 15 & - & - & - & - & - \\
\hline M-015-81 & 1 & $1,2,2,1$ & $1,2,2, ?$ & $1,2,3,3,2$ & $1,2,2,1$ & $1,2,2,2$ \\
\hline M-015-81 & 2 & - & - & $1,2, ?$ & $1,2,2,1$ & $1,2, ?$ \\
\hline M-015-81 & 3 & $1,2, ?$ & $1,2, ?$ & $1,2, ?$ & $1,2, ?$ & $1,2, ?$ \\
\hline M-015-82 & 1 & $1,2,2,1$ & $1,2,2,1$ & $1,2,3,2, ?$ & $1,2,2,1$ & $1,2,2,1$ \\
\hline M-015-82 & 3 & $1,2,2,1$ & $1,2,2,1$ & $1,2,3,2,3$ & $1,2,1,1$ & $1,2,2,1$ \\
\hline M-015-82 & 4 & $1,2,2,1$ & $1,2,2$ & - & $1,2,1$ & $1,2,1$ \\
\hline M-015-82 & 5 & $1,2,1,1$ & $1,2,2, ?$ & $1,2, ?, 1$ & - & $1,2,2,2$ \\
\hline M-015-82 & 6 & $1,2,2,1$ & $1,2,2,1$ & $1,2,3,1$ & $1,2,2,1$ & $1,2,2,1$ \\
\hline M-015-82 & 2 & $1,2,2,2,1$ & $1,2,2,1,1$ & 1,2,?,1 & $1,2,2,1,1$ & $1,2,2,1,1$ \\
\hline M-015-82 & 7 & $1,2,2,1$ & $1,2, ?$ & - & - & - \\
\hline M-015-83 & 1 & $1,2, ?, 2$ & $1,2,2,1$ & $1,2,2,2,1$ & $1,2, ?, 1$ & $1,2, ?$ \\
\hline M-015-83 & 3 & $1,2,1,1$ & $1,2,2,1$ & $1,2,3,2,1$ & $1,2,2,1$ & $1,2,2,1$ \\
\hline M-015-83 & 4 & $1,2, ?, 1$ & $1,2, ?$ & $1,2, ?$ & 1,2,?,2 & - \\
\hline M-015-83 & 5 & $1,2,2,2$ & $1,2,2,1$ & $1,2,3,3,1$ & 1,2,?,1 & 1,2,?, \\
\hline M-015-83 & 13 & $1,2, ?$ & $1,2,2, ?$ & $1,2,3, ?$ & 1,2,?,1 & $1,2,2, ?$ \\
\hline M-015-83 & 15 & - & $1,2,2,1$ & $1,2,2,1$ & - & - \\
\hline M-015-83 & 16 & - & $1,2, ?$ & $1,2,2,2,1$ & $1,2,1$ & - \\
\hline M-015-83 & 17 & - & - & $1,2,3,1$ & - & $1,2,1,1$ \\
\hline M-015-83 & 20 & $1,2, ?$ & $1,2,1$ & $1,2,3, ?$ & $1,2,1,1$ & $1,2,2,1$ \\
\hline M-015-83 & 21 & $1,2,2,1, ?$ & $1,2,2,2,1$ & $1,2, ?$ & - & - \\
\hline M-015-83 & 23 & - & - & $1,2,3, ?$ & $1,2,2,1$ & $1,2,2,1,1$ \\
\hline M-015-83 & 2 & - & $1,2, ?$ & $1,2,3, ?, 2$ & - & $1,2, ?$ \\
\hline M-015-83 & 6 & - & - & - & - & - \\
\hline M-015-83 & 7 & - & $1,2, ?, ?, 1$ & $1,2, ?$ & - & - \\
\hline M-015-83 & 8 & $1,2,2,1$ & - & - & - & - \\
\hline M-015-83 & 9 & $1,2, ?$ & $1,2, ?$ & $1,3, ?$ & - & - \\
\hline M-015-83 & 10 & $1,2, ?, 1$ & 1,2,?,1 & - & - & - \\
\hline M-015-83 & 11 & - & - & - & $1,2,1,1$ & - \\
\hline M-015-83 & 12 & 1,2,?,2 & - & - & - & - \\
\hline M-015-83 & 14 & $1,2,1$ & - & - & - & - \\
\hline M-015-83 & 18 & - & - & - & - & - \\
\hline M-015-83 & 19 & - & - & - & - & - \\
\hline M-015-83 & 22 & - & - & - & - & - \\
\hline M-015-83 & 24 & - & - & - & - & - \\
\hline M-015-83 & 25 & - & - & - & - & - \\
\hline M-015-85 & 2 & $1,2,2$ & $1,2,1$ & $1,2,3, ?$ & $1,2,2$ & $1,2,1$ \\
\hline
\end{tabular}




\begin{tabular}{|c|c|c|c|c|c|c|}
\hline Locality & Specimen \# & A-B & $\mathrm{B}-\mathrm{C}$ & C-D & D-E & E-A \\
\hline M-015-85 & 4 & $1,2,2,1$ & $1,2,2,2$ & $1,2,3,1,1$ & 1,?,?,2 & $1,2, ?$ \\
\hline M-015-85 & 8 & $1,2, ?$ & $1,2, ?$ & $1,2,3,2,1$ & - & $1,2, ?, 2$ \\
\hline M-015-85 & 12 & $1,2,2,1$ & $1,2,2,1$ & $1,2,2, ?, 1$ & $1,2,2,1$ & - \\
\hline M-015-85 & 13 & $1,2,2, ?$ & $1,2, ?$ & $1,3,3, ?$ & $1,2,2,1$ & - \\
\hline M-015-85 & 20 & - & $1,2,2,1$ & $1,2,3,2,1$ & - & - \\
\hline M-015-85 & 9 & - & - & $1,2,3,2,2$ & 1,2,?,2 & - \\
\hline M-015-85 & 17 & 1,2,?,2 & $1,2, ?$ & $1,2, ?$ & $1,2, ?, 1$ & $1,2, ?, 2$ \\
\hline M-015-85 & 1 & $1,2,2,1$ & - & - & $1,2, ?$ & $1,2,2,2$ \\
\hline M-015-85 & 3 & - & - & - & - & - \\
\hline M-015-85 & 5 & - & - & - & - & - \\
\hline M-015-85 & 6 & - & - & - & - & - \\
\hline M-015-85 & 7 & - & - & - & - & - \\
\hline M-015-85 & 10 & - & - & - & - & - \\
\hline M-015-85 & 11 & $1,2,2,1$ & - & - & - & - \\
\hline M-015-85 & 14 & $1,2,2,1,1$ & - & - & - & - \\
\hline M-015-85 & 15 & - & - & - & - & - \\
\hline M-015-85 & 16 & - & - & - & - & - \\
\hline M-015-85 & 18 & $1,2, ?, 2$ & - & - & - & - \\
\hline M-015-85 & 19 & $1,2,2, ?$ & $1,2, ?, 1$ & - & - & - \\
\hline M-015-117 & 1 & $1,2,2,1$ & $1,2, ?, 1$ & $1,2,1,1$ & $1,2,1$ & $1,2, ?, 1$ \\
\hline M-015-117 & 2 & $1,2,2,2$ & $1,2,2,1$ & $1,2,3,1,2$ & $1,2,2,2$ & $1,2,2,2$ \\
\hline M-016-02 & 1 & $1,2,1,1$ & $1,2,1,1$ & $1,2,2,1,1$ & $1,2,1,1$ & $1,2,1,1$ \\
\hline M-016-12 & 2 & $1,2,1$ & $1,2,1$ & $1,2,2,1, ?$ & $1,2,1$ & $1,2,1$ \\
\hline M-016-12 & 3 & $1,2,1,1$ & $1,2, ?$ & $1,2,2 ?, 1 ?$ & - & - \\
\hline M-016-12 & 4 & $1,2,1$ & $1,2,1$ & $1,2,2,1$ & $1,2,1$ & $1,2, ?$ \\
\hline M-016-12 & 1 & $1,2,2, ?$ & $1,2,2,1$ & $1,2,2,1$ & $1,2,1,1$ & $1,2,2,1$ \\
\hline M-017-04 & 1 & $1,2, ?, 2$ & $1,2, ?$ & $1,2,3,1,2$ & $1,2, ?$ & $1,2,2,2$ \\
\hline M-017-04 & 2 & - & $1,2, ?$ & $1,2,3, ?$ & $1,2, ?$ & - \\
\hline M-017-07 & 1 & $1,2,2,1$ & $1,2,1,1$ & $1,2,3,1$ & - & $1,2,2,1$ \\
\hline M-017-07 & 6 & - & - & $1,2,3,2$ & $1,2,1$ & $1,2,1,2$ \\
\hline M-017-07 & 8 & $1,2,1$ & $1,2,1$ & - & $1,2,1$ & $1,2,1$ \\
\hline M-017-07 & 9 & - & - & $1,2,3,2,1$ & $1,2,2,1$ & $1,2,2,1$ \\
\hline M-017-07 & 11 & $1,2,2,1$ & $1,2,1,1$ & - & $1,2,2,2$ & - \\
\hline M-017-07 & 13 & $1,2, ?$ & $1,2,2,1$ & $1,2,3,1,1$ & - & - \\
\hline M-017-07 & 20 & $1,2,2, ?$ & $1,2,2,1$ & $1,2,3, ?$ & - & $1,2,1,1$ \\
\hline M-017-07 & 10 & $1,2,2,1$ & $1,2,2,1$ & $1,2,3,2, ?$ & $1,2,2,2,1$ & $1,2,2, ?, 1$ \\
\hline M-017-07 & 22 & $1,2, ?$ & $1,2,2$ & $1,2,2,1,2$ & - & - \\
\hline M-017-07 & 23 & $1,2,2,2,2$ & $1,2,2,2$ & $1,2,3,2,2$ & $1,2,2,2,1$ & $1,2,2,2,1$ \\
\hline M-017-07 & 24 & - & $1,2, ?, 1$ & $1,2,2,2, ?$ & - & $1,2, ?, 2$ \\
\hline M-017-07 & 26 & $1,2, ?, 1$ & - & $1,2,3, ?$ & - & $1,2, ?, 1$ \\
\hline M-017-07 & 5 & $1,2,2$ & $1,2, ?$ & $1,2,3,3$ & $1,2,1,2$ & $1,2,2$ \\
\hline
\end{tabular}




\begin{tabular}{|c|c|c|c|c|c|c|}
\hline Locality & Specimen \# & A-B & $\mathrm{B}-\mathrm{C}$ & C-D & D-E & E-A \\
\hline M-017-07 & 2 & $1,2,2,2$ & $1,2,2,1$ & - & $1,2,2, ?$ & $1,2, ?$ \\
\hline M-017-07 & 3 & $1,2,2,1$ & $1,2,2,1$ & - & - & - \\
\hline M-017-07 & 4 & $1,2,2, ?, 1$ & - & - & - & - \\
\hline M-017-07 & 7 & - & - & - & $1,2,2$ & - \\
\hline M-017-07 & 12 & - & - & - & - & - \\
\hline M-017-07 & 14 & - & - & - & - & - \\
\hline M-017-07 & 15 & $1,2, ?, 2$ & - & $1,2, ?$ & $1,2, ?$ & - \\
\hline M-017-07 & 16 & $1,2,1$ & $1,2,1$ & - & $1,2,1$ & - \\
\hline M-017-07 & 17 & $1,2,1,2$ & $1,2,1,1$ & - & $1,2,1,1$ & - \\
\hline M-017-07 & 18 & - & - & $1,2, ?$ & - & $1,2,2,1$ \\
\hline M-017-07 & 19 & $1,2,2,2,1$ & $1,2,2,2,1$ & - & $1,2, ?$ & - \\
\hline M-017-07 & 21 & $1,2,1$ & - & - & - & - \\
\hline M-017-07 & 25 & - & - & - & - & - \\
\hline M-017-07 & 27 & - & - & - & - & - \\
\hline M-017-07 & 28 & $1,2, ?, 2$ & - & - & - & - \\
\hline M-017-07 & 29 & - & - & - & - & - \\
\hline M-017-09 & 1 & $1,2,2,1$ & $1,2,2,1$ & $1,2,3,1,1$ & $1,2,2,1$ & $1,2,2,2$ \\
\hline M-017-09 & 3 & $1,2,2,1$ & $1,2,2,1$ & $1,2,2,1$ & $1,2,2,1$ & $1,2,2,1$ \\
\hline M-017-09 & 4 & $1,2, ?$ & $1,2, ?$ & $1,2,3,2,1$ & $1,2,2,1$ & $1,2,2,1$ \\
\hline M-017-09 & 5 & $1,2,2,1$ & $1,2, ?$ & 1,2,3,?,2 & $1,2,2,1$ & $1,2,2,2,1$ \\
\hline M-017-09 & 9 & $1,2,2,1$ & $1,2,1,1$ & $1,2,3,2$ & $1,2,1$ & $1,2,2,1$ \\
\hline M-017-09 & 10 & - & $1,2, ?$ & $1,2, ?$ & $1,2,1$ & $1,2,1$ \\
\hline M-017-09 & 11 & $1,2,2,2$ & $1,2,2,2$ & $1,3,2,2$ & $1,2, ?, 1$ & $1,2, ?$ \\
\hline M-017-09 & 13 & $1,2, ?, 2$ & $1,2, ?$ & $1,2,2,2,1$ & - & - \\
\hline M-017-09 & 16 & $1,2,2,1$ & $1,2, ?$ & $1,2,3, ?$ & $1,2, ?, 1$ & $1,2,2,1$ \\
\hline M-017-09 & 17 & $1,1,2,2$ & $1,2,2,1$ & $1,2,2,2,2$ & - & - \\
\hline M-017-09 & 19 & $1,2,1$ & - & $1,2,2,1$ & $1,2, ?$ & $1,2,2$ \\
\hline M-017-09 & 20 & $1,2,2,1$ & $1,2,2,2$ & $1,3,2, ?$ & $1,2,2,2$ & $1,2, ?$ \\
\hline M-017-09 & 21 & $1,2, ?$ & $1,2,1,1$ & $1,2,3,2$ & - & $1,2,2$ \\
\hline M-017-09 & 28 & $1,2,2,1$ & $1,2,2,1$ & $1,2,2,2,1$ & $1,2,2,2$ & $1,2,2, ?$ \\
\hline M-017-09 & 32 & $1,2, ?$ & 1,2,?,2 & $1,2,3, ?$ & $1,2,2$ & - \\
\hline M-017-09 & 2 & $1,2, ?, 1$ & $1,2, ?$ & $1,2,3,2,1$ & $1,2,2,1,2$ & $1,2,2, ?, 1$ \\
\hline M-017-09 & 7 & $1,2, ?, 1$ & $1,2,2,2$ & $1,2,2,2$ & - & $1,2,2,2$ \\
\hline M-017-09 & 8 & $1,2,1,2$ & $1,2,2$ & $1,2,3,2,2$ & $1,2,2,2$ & $1,2,2,1$ \\
\hline M-017-09 & 12 & $1,2,2,2$ & $1,2,2,2$ & $1,2,3, ?$ & $1,2,2$ & $1,2,2$ \\
\hline M-017-09 & 18 & $1,2,2,2$ & $1,2,2,2$ & $1,3,2,2$ & $1,2,2,2$ & $1,2, ?$ \\
\hline M-017-09 & 23 & $1,2, ?$ & $1,2,2,1$ & $1,2,3,2$ & $1,2,2$ & $1,2,2,2$ \\
\hline M-017-09 & 26 & $1,2,2, ?$ & $1,2,2,1$ & $1,2,3,1,1$ & $1,2,2,2$ & $1,2,1,2$ \\
\hline M-017-09 & 30 & $1,2,2,2$ & $1,2,2,2$ & $1,2,3,2,1$ & $1,2,2,2$ & $1,2, ?$ \\
\hline M-017-09 & 31 & - & - & 1,2,3,2 & $1,2,2,2$ & - \\
\hline M-017-09 & 35 & $1,2,2,1,1$ & - & - & $1,2,2,2$ & $1,2,2,2$ \\
\hline
\end{tabular}




\begin{tabular}{|c|c|c|c|c|c|c|}
\hline Locality & Specimen \# & A-B & $\mathrm{B}-\mathrm{C}$ & C-D & D-E & E-A \\
\hline M-017-09 & 36 & - & $1,2,2,1$ & $1,2,2,2,2$ & - & - \\
\hline M-017-09 & 39 & $1,2, ?$ & $1,2, ?$ & $1,2,3,2$ & $1,2, ?$ & $1,2,2,1$ \\
\hline M-017-09 & 6 & $1,2, ?$ & - & - & $1,2,2,2,1$ & $1,2,2, ?$ \\
\hline M-017-09 & 14 & $1,2,2,1$ & - & - & - & - \\
\hline M-017-09 & 15 & $1,2,2,2$ & $1,2,2,2$ & - & - & - \\
\hline M-017-09 & 22 & - & $1,2, ?$ & $1,2,3, ?$ & $1,2,2$ & - \\
\hline M-017-09 & 24 & - & - & - & - & - \\
\hline M-017-09 & 25 & $1,2,2,1$ & $1,2, ?$ & - & - & - \\
\hline M-017-09 & 27 & $1,2, ?$ & - & $1,2,3, ?$ & $1,2, ?$ & - \\
\hline M-017-09 & 29 & - & - & - & - & - \\
\hline M-017-09 & 33 & - & $1,2,2, ?$ & $1,2,3,2$ & - & - \\
\hline M-017-09 & 34 & - & - & - & - & - \\
\hline M-017-09 & 37 & $1,2, ?$ & - & - & - & - \\
\hline M-017-09 & 38 & $1,2,2,1$ & - & - & - & $1,2, ?$ \\
\hline M-017-13 & 1 & $1,2, ?, 2$ & $1,2, ?$ & $1,2, ?$ & $1,2,1,1$ & $1,2,2,2$ \\
\hline M-017-13 & 2 & $1,2,2,2$ & - & - & - & - \\
\hline M-017-13 & 3 & - & $1,2, ?$ & $1,2,3,1$ & $1,2, ?$ & $1,2, ?$ \\
\hline M-017-31 & 1 & $1,2,2,1$ & $1,2,2,1$ & $1,2,3,1,1$ & $1,2, ?$ & $1,2,2,1$ \\
\hline M-017-31 & 2 & $1,2, ?, 1$ & $1,2, ?$ & $1,2,3,1$ & 1,2,?,1 & $1,2, ?$ \\
\hline M-017-31 & 3 & $1,2, ?$ & $1,2, ?$ & $1,2,2,2,1$ & - & $1,2,2,1$ \\
\hline M-017-31 & 7 & - & - & $1,2,3, ?$ & $1,2,2,1$ & $1,2,1,1$ \\
\hline M-017-31 & 11 & $1,2,1,1$ & $1,2,2,1$ & $1,1,2,1,1$ & - & $1,2,1$ \\
\hline M-017-31 & 12 & $1,2, ?, 2$ & $1,2,2,1$ & - & - & 1,2,?,2 \\
\hline M-017-31 & 13 & - & - & $1,2,3,1,1$ & $1,2,1,1$ & $1,2,2,1$ \\
\hline M-017-31 & 15 & $1,2,2,1$ & $1,2,2,1$ & $1,2,3,2,1$ & $1,2,2, ?$ & $1,2,2,1$ \\
\hline M-017-31 & 5 & $1,2,2,1$ & $1,2, ?$ & $1,2,3,2, ?$ & $1,2,2,1$ & $1,2,2,2$ \\
\hline M-017-31 & 8 & $1,2,2, ?$ & - & $1,2,3,2$ & $1,2,2,2$ & $1,2,2,1$ \\
\hline M-017-31 & 9 & $1,2,2, ?, 1$ & 1,2,2,?,1 & $1,2,3,1,1$ & $1,2,2, ?, 1$ & $1,2,2,2,1$ \\
\hline M-017-31 & 4 & $1,2,2,1$ & $1,2, ?$ & - & - & - \\
\hline M-017-31 & 6 & - & $1,2, ?$ & - & $1,2, ?$ & - \\
\hline M-017-31 & 10 & $1,2, ?, 1$ & - & - & - & $1,2, ?$ \\
\hline M-017-31 & 14 & $1,2, ?$ & $1,2, ?$ & - & $1,2, ?$ & - \\
\hline M-017-31 & 16 & $1,2, ?, 1$ & $1,2,2,1$ & - & - & - \\
\hline M-017-40 & 1 & $1,2,2,1$ & - & $1, ?$ & 1,2,?,1 & $1,2,1,1$ \\
\hline M-017-40 & 6 & $1,2,1,1$ & - & $1,2,2,1$ & $1,2,2, ?$ & - \\
\hline M-017-40 & 7 & $1,2,1$ & $1, ?, 1$ & $1,2, ?$ & $1,2,1$ & $1,2,1$ \\
\hline M-017-40 & 8 & $1,2,2,1$ & $1,2,1$ & $1,2,3,2,2$ & $1,2,2,1$ & $1,2,2,1$ \\
\hline M-017-40 & 10 & $1,2,2,1$ & $1,2,2,1$ & $1,2,3,2,1$ & $1,2,1,2$ & $1,2,2,1$ \\
\hline M-017-40 & 11 & $1,2,2,1$ & $1,2,1,2$ & $1,2,2,2$ & $1,2, ?$ & - \\
\hline M-017-40 & 12 & $1,2,2, ?$ & $1,2,2,2$ & $1,2,3,1,1$ & $1,2,2,1$ & $1,2, ?$ \\
\hline M-017-40 & 16 & $1,2,2,1$ & $1,2,2, ?$ & $1,2,3,1$ & $1,2,2,1$ & $1,2,2,1$ \\
\hline
\end{tabular}




\begin{tabular}{|c|c|c|c|c|c|c|}
\hline Locality & Specimen \# & A-B & $\mathrm{B}-\mathrm{C}$ & C-D & D-E & E-A \\
\hline M-017-40 & 17 & - & - & $1,2,3,1$ & - & $1,2,2,1$ \\
\hline M-017-40 & 2 & $1,2,2,1$ & $1,2,2,2$ & 1,2,?,?,2 & $1,2, ?, 1$ & $1,2,2,1,1$ \\
\hline M-017-40 & 3 & $1,2,2, ?, 1$ & $1,2,2,1, ?$ & $1,2,3,2,1$ & $1,2,2,1$ & $1,2,2, ?, 1$ \\
\hline M-017-40 & 5 & $1,2,2,1$ & $1,2,2, ?$ & $1,2,3, ?$ & - & $1,2,2,2,1$ \\
\hline M-017-40 & 9 & $1,2,2,1$ & $1,2, ?, 1$ & $1,2,3,2, ?$ & - & $1,2,2,2,2$ \\
\hline M-017-40 & 4 & $1,2,2,2$ & $1,2,2,2$ & - & - & - \\
\hline M-017-40 & 13 & $1,2, ?$ & $1,2, ?$ & - & - & - \\
\hline M-017-40 & 14 & $1,2, ?$ & $1,2, ?, 1$ & - & $1,2, ?, 1$ & - \\
\hline M-017-40 & 15 & $1,2, ?, 2$ & - & - & - & $1,2,1,1$ \\
\hline M-017-40 & 18 & - & - & $1,2,3,2,2$ & - & - \\
\hline M-017-40 & 19 & - & - & - & - & - \\
\hline M-017-40 & 20 & - & - & - & - & - \\
\hline M-018-3 & 1 & - & - & - & - & - \\
\hline M-018-7 & 1 & $1,2,2,1,2$ & $1,2,2,1$ & - & $1,2,2,1$ & - \\
\hline M-019-10 & 5 & $1,2,1,1$ & $1,2, ?$ & $1,2,3, ?$ & $1,2,2,1$ & $1,2,1,1$ \\
\hline M-019-10 & 1 & - & $1,2,1,1$ & $1,2,3,2,2$ & $1,2,1,2$ & - \\
\hline M-019-10 & 2 & $1,2,2,1$ & $1,2,2,1$ & $1,2,3,2,1$ & $1,2,2,2$ & $1,2,2,1$ \\
\hline M-019-10 & 4 & $1,2,2,2$ & $1,2,1,2$ & $1,2,3,2,2$ & $1,2,2,2$ & $1,2,2,2$ \\
\hline M-019-10 & 6 & $1,2, ?, 1$ & $1,2, ?$ & $1,2,3,2,1$ & $1,2, ?$ & $1,2, ?$ \\
\hline M-019-10 & 7 & - & - & $1,2,3,2,2$ & - & - \\
\hline M-019-10 & 9 & - & - & $1,2, ?$ & - & $1,2,2,2$ \\
\hline M-019-10 & 3 & $1,2,2,1$ & - & $1,3,2,1$ & $1,2,2,1$ & $1,2,2,1$ \\
\hline M-019-10 & 8 & - & - & $1,2,3, ?$ & $1,2, ?, 2$ & - \\
\hline M-019-10 & 10 & - & - & - & - & - \\
\hline M-019-17 & 4 & $1,2,1, ?$ & $1,2,2, ?, 1$ & $1,2,2,1,1$ & $1,2, ?$ & $1,2,1,1$ \\
\hline M-019-17 & 14 & - & 1,2,?,1 & $1,2,2, ?, 1$ & $1,2,1,1$ & - \\
\hline M-019-17 & 20 & $1,2,1$ & $1,2,1$ & $1,2,2,1,1$ & $1,2,1$ & $1,2,1$ \\
\hline M-019-17 & 3 & $1,2,2,1$ & $1,2,2,1$ & $1,2,3,1,1$ & $1,2,2,1,1$ & $1,2, ?$ \\
\hline M-019-17 & 5 & $1,2, ?, 2$ & $1,2, ?, 1$ & $1,2,3,2,1$ & $1,2,2,2$ & - \\
\hline M-019-17 & 6 & $1,2,2,1,2$ & $1,2,2,2,1$ & $1,2,4,3,1$ & $1,2,2,2,1$ & $1,2,2,2, ?$ \\
\hline M-019-17 & 7 & $1,2,2,1$ & $1,1 ?, 1,1$ & $1,2,3,2,2$ & 1,2,?,2 & $1,2,1,1$ \\
\hline M-019-17 & 9 & $1,2,2,1$ & $1,2,1, ?$ & $1,2,3, ?$ & $1,2,2,1,2$ & $1,2,2,2$ \\
\hline M-019-17 & 10 & $1,2,2,2,1$ & $1,2,2,1,2$ & $1,2,3,2,1$ & $1,2,2,1$ & $1,2,2,2$ \\
\hline M-019-17 & 11 & $1,2,2,2$ & $1,2,2,2$ & $1,2,3,1,1$ & $1,2,2,2$ & $1,2,2,1$ \\
\hline M-019-17 & 12 & $1,2,2,2,1$ & $1,2,2, ?$ & $1,2,3,3,1$ & $1,2,2,2,1$ & $1,2,2,2,2$ \\
\hline M-019-17 & 15 & $1,2,2,2,1$ & $1,2,2,2,1$ & $1,2,3,2 ?, 1$ & $1,2,2,2,1$ & $1,2,2,2,1$ \\
\hline M-019-17 & 16 & - & $1,2, ?$ & $1,2,3,2,2$ & - & - \\
\hline M-019-17 & 18 & $1,2, ?$ & $1,2,2,1$ & $1,2,3,2,1$ & $1,2,2,1$ & - \\
\hline M-019-17 & 21 & - & $1,2,2,2$ & $1,2,3,2,1$ & - & - \\
\hline M-019-17 & 23 & - & - & $1,2,3,2,1$ & - & - \\
\hline M-019-17 & 24 & $1,2,2$ & $1,2, ?$ & $1,2,3,2,2$ & $1,2, ?$ & $1,2,1$ \\
\hline
\end{tabular}




\begin{tabular}{|c|c|c|c|c|c|c|}
\hline Locality & Specimen \# & A-B & $\mathrm{B}-\mathrm{C}$ & C-D & D-E & E-A \\
\hline M-019-17 & 1 & $1,2,1, ?$ & $1,2,1, ?$ & $1,2,3,2,1$ & $1,2,2,1$ & $1,2,1,1$ \\
\hline M-019-17 & 2 & $1,2, ?, 1$ & - & $1,2,3, ?$ & $1,2, ?$ & $1,2, ?, 1$ \\
\hline M-019-17 & 8 & $1,2,1,1$ & $1,2,1,1$ & - & - & - \\
\hline M-019-17 & 13 & $1,2,2,1$ & - & - & - & - \\
\hline M-019-17 & 17 & $1,2,2, ?$ & - & - & - & - \\
\hline M-019-17 & 19 & $1,2,1,1$ & - & - & - & - \\
\hline M-019-17 & 22 & - & - & - & - & - \\
\hline M-019-17 & 25 & $1,2,2$ & - & - & - & - \\
\hline M-021-3 & 1 & - & $1,2,1$ & $1,2,2$ & $1,2,2$ & - \\
\hline M-021-3 & 2 & $1,2,1$ & - & - & - & - \\
\hline M-022-04 & 1 & - & - & - & $1,2, ?$ & $1,2,2,2$ \\
\hline M-022-12 & 3 & - & - & $1,2,3,1$ & - & - \\
\hline M-022-12 & 1 & $1,2,2,2$ & $1, ?$ & $1,2,3, ?$ & - & $1,2, ?, 2$ \\
\hline M-022-12 & 2 & - & - & - & - & - \\
\hline M-022-14 & 1 & $1,2, ?, 1$ & $1,2, ?, 1$ & $1,2,2, ?$ & $1,2,1,1$ & $1,2,1,1$ \\
\hline M-022-14 & 2 & $1,2, ?$ & $1,2, ?$ & $1,2,3,1$ & $1,2,1,2$ & $1,2,1,2$ \\
\hline M-022-14 & 4 & - & - & $1,2,2, ?$ & $1,2,1,1$ & $1, ?, ?, 1$ \\
\hline M-022-14 & 6 & $1,2,1,2$ & $1,2,1,2$ & - & $1,2, ?$ & $1,2,1,2$ \\
\hline M-022-14 & 8 & $1,2,1,1$ & $1,2,1,1$ & $1,2,3,2, ?$ & $1,2,1, ?$ & - \\
\hline M-022-14 & 9 & $1,2, ?$ & - & 1,2,3,?,2 & $1,2,1,1$ & $1,2,2,1$ \\
\hline M-022-14 & 21 & - & - & $1,2,3,2$ & $1,2,1,1$ & - \\
\hline M-022-14 & 5 & $1,2, ?$ & $1,2,2,2,2$ & $1,2,3, ?$ & $1,2, ?$ & $1,2,2, ?$ \\
\hline M-022-14 & 10 & - & $1,2, ?, 2$ & $1,3,2,1$ & $1,2,2, ?, 1$ & - \\
\hline M-022-14 & 11 & - & $1,2,2,2$ & 1,3,3,2,1 & - & - \\
\hline M-022-14 & 12 & - & - & $1,2,3,2,2$ & $1,2, ?$ & - \\
\hline M-022-14 & 19 & $1,2,2, ?$ & - & $1,3,3,2,1$ & $1,2, ?$ & $1,2,2,1$ \\
\hline M-022-14 & 20 & $1,2,2,2$ & $1,2, ?$ & $1,2,2, ?$ & - & - \\
\hline M-022-14 & 27 & - & - & $1,2,3,2,1$ & - & - \\
\hline M-022-14 & 30 & $1,2,2,1$ & $1,2,2,1$ & $1,2,3,2,2$ & $1,2,2$ & $1,2,2,2$ \\
\hline M-022-14 & 3 & $1,2,1$ & - & - & - & - \\
\hline M-022-14 & 7 & - & - & - & - & - \\
\hline M-022-14 & 13 & - & - & - & - & - \\
\hline M-022-14 & 14 & - & - & - & - & - \\
\hline M-022-14 & 15 & $1,2,1$ & $1,2,1$ & - & - & - \\
\hline M-022-14 & 16 & $1,2,1,1$ & - & - & - & - \\
\hline M-022-14 & 17 & $1,2,2$ & - & - & - & - \\
\hline M-022-14 & 18 & - & - & - & - & - \\
\hline M-022-14 & 22 & $1,2,2,1$ & - & - & - & - \\
\hline M-022-14 & 23 & - & - & - & - & - \\
\hline M-022-14 & 24 & - & - & - & - & - \\
\hline M-022-14 & 25 & $1,2,2,2$ & - & - & - & - \\
\hline
\end{tabular}




\begin{tabular}{|c|c|c|c|c|c|c|}
\hline Locality & Specimen \# & A-B & $\mathrm{B}-\mathrm{C}$ & C-D & D-E & E-A \\
\hline M-022-14 & 26 & - & - & - & - & - \\
\hline M-022-14 & 28 & $1,2,2,1$ & - & - & - & - \\
\hline M-022-14 & 29 & $1,2,2,1$ & - & - & - & - \\
\hline M-022-59 & 1 & $1,2,1,2$ & $1,2,2,2$ & $1,2,3,2$ & - & - \\
\hline M-022-59 & 3 & $1,2,1,2$ & $1,2,1, ?$ & $1,2,3,2, ?$ & $1,2,2,1$ & $1,2,1,1$ \\
\hline M-022-59 & 7 & $1,2,1$ & $1,2,1$ & $1,2,2,1$ & $1,2,1$ & - \\
\hline M-022-59 & 8 & $1,2, ?$ & $1,2,1,2$ & 1,2,3,?,2 & - & - \\
\hline M-022-59 & 2 & $1,2,2, ?$ & $1,2,2, ?$ & $1,2,3,2,2,1$ & $1,2,2,1$ & $1,2,2,1$ \\
\hline M-022-59 & 5 & $1,2,2,1$ & $1,2,1,1$ & $1,2,2,2, ?$ & $1,2,2,1$ & $1,2,2,1$ \\
\hline M-022-59 & 4 & $1,2,2,1$ & $1,2,1,1$ & - & - & - \\
\hline M-022-59 & 6 & $1,2,2,1$ & $1,2,2,1$ & - & - & - \\
\hline M-080-8 & 1 & $1,2,2,1$ & $1,2,1,1$ & $1,2,2,2,1$ & $1,2,2,1$ & $1,2,2,1$ \\
\hline M-086-3 & 1 & $1,2,2$ & $1,2, ?$ & $1,2,1,2$ & $1,2,2$ & $1,2,2$ \\
\hline M-086-5 & 1 & $1,2,2,1$ & - & - & - & - \\
\hline M-086-5 & 2 & - & $1,2,1,1$ & - & - & - \\
\hline M-086-5 & 3 & $1,2, ?$ & $1,2, ?, 1$ & $1,2,3, ?$ & $1,2, ?$ & - \\
\hline M-087-09 & 1 & $1,2,2, ?$ & $1,2, ?, 2$ & $1,2, ?$ & $1,2, ?, 2$ & $1,2,2,1$ \\
\hline M-087-12 & 13 & $1,2,1,1$ & $1,2,1,1$ & $1,3, ?$ & $1,2,2,1$ & - \\
\hline M-087-12 & 14 & $1,2,2,1$ & $1,2,2,2,1$ & $1,2,2,1,1$ & $1,2,2,2$ & $1,2,2,1,1$ \\
\hline M-087-12 & 1 & $1,2,2,1$ & $1,2,2, ?$ & $1,2,2, ?, 1$ & $1,2,2,1$ & $1,2, ?$ \\
\hline M-087-12 & 2 & 1,2,?,2 & $1,2, ?, 2$ & - & $1,2,2,2$ & - \\
\hline M-087-12 & 3 & $1,2,2,1$ & $1,2,2,1$ & $1,2, ?$ & $1,2,1$ & $1,2,2,1$ \\
\hline M-087-12 & 7 & $1,2,2,2,1$ & $1,2,2,2,2$ & $1,2,3,2,2$ & $1,2,2,1$ & $1,2,2,1$ \\
\hline M-087-12 & 8 & 1,2,?,1 & $1,2,1,1$ & $1,2,3,3$ & $1,2,2,2$ & - \\
\hline M-087-12 & 4 & $1,2,2,2$ & - & - & - & - \\
\hline M-087-12 & 5 & - & - & $1,2, ?$ & - & - \\
\hline M-087-12 & 6 & $1,2,2,2,2$ & - & - & - & - \\
\hline M-087-12 & 9 & - & - & - & - & - \\
\hline M-087-12 & 10 & - & - & - & - & - \\
\hline M-087-12 & 11 & $1,2,1$ & - & - & - & - \\
\hline M-087-12 & 12 & - & - & $1,2, ?$ & - & - \\
\hline M-091-1 & 1 & $1,2,2,1$ & - & $1,2,3, ?, 1$ & $1,2,1,2$ & $1,2,2,1$ \\
\hline M-091-1 & 2 & - & $1,2, ?$ & $1,2,3, ?, 1$ & - & - \\
\hline M-091-7 & 1 & $1,2,2,2$ & $1,2,2,1$ & $1,2,3,1,1$ & $1,2,2,1$ & $1,2, ?, 2$ \\
\hline M-091-7 & 2 & $1,2,1,1$ & $1,2, ?, 1$ & - & $1,2,2,1$ & - \\
\hline M-091-9 & 3 & $1,2,2,1$ & $1,2,2,1$ & $1,2, ?$ & $1,2, ?$ & $1,2,2,1$ \\
\hline M-091-9 & 4 & - & $1,2,2,1$ & $1,2, ?$ & - & - \\
\hline M-091-9 & 5 & - & $1,2,1$ & $1,2,3,2,3$ & - & - \\
\hline M-091-9 & 9 & - & $1,2, ?$ & $1,2,3,1$ & $1,2,2$ & - \\
\hline M-091-9 & 6 & $1,2,2,2$ & $1,2,2,1,2$ & $1,2,3,2,1$ & $1,2, ?$ & $1,2,2,2$ \\
\hline M-091-9 & 8 & $1,2,2, ?$ & $1,2,2,2,1$ & $1,2,3,2,2$ & $1,2,2, ?, 1$ & - \\
\hline
\end{tabular}




\begin{tabular}{|c|c|c|c|c|c|c|}
\hline Locality & Specimen \# & A-B & $\mathrm{B}-\mathrm{C}$ & C-D & D-E & E-A \\
\hline M-091-9 & 1 & $1,2,2,1$ & - & - & - & - \\
\hline M-091-9 & 2 & $1,2,2,1$ & - & - & - & - \\
\hline M-091-9 & 7 & $1,2, ?, 3$ & - & - & - & - \\
\hline M-091-9 & 10 & - & - & $1,2,2,2,1$ & - & - \\
\hline M-091-9 & 11 & $1,2, ?, 2$ & - & - & - & - \\
\hline M-092-1 & 5 & - & $1,2,1,1$ & $1,2, ?, ?, 1$ & - & - \\
\hline M-092-1 & 1 & $1,2, ?, 1$ & $1,2, ?, 1$ & $1,2,3,2,1$ & $1,2, ?, 1$ & $1,2, ?$ \\
\hline M-092-1 & 2 & $1,2,1, ?$ & $1,2,2,1$ & $1,2,2,2,2$ & $1,2,2,1$ & $1,2, ?$ \\
\hline M-092-1 & 3 & $1,2,2,2,2$ & $1,2,2, ?, 2$ & $1,2,3,2,2$ & $1,2, ?$ & $1,2, ?, 2$ \\
\hline M-092-1 & 4 & - & - & - & - & - \\
\hline M-092-2 & 5 & $1,2, ?$ & $1,2, ?$ & $1,2,3,2,2$ & $1,2,2,1$ & $1,2,1$ \\
\hline M-092-2 & 6 & $1,2,2,1$ & $1,2,1,1$ & $1,2,3,2, ?$ & $1,2,2,1$ & $1,2,2,1$ \\
\hline M-092-2 & 1 & $1,1,1$ & $1, ?$ & $1,2,3,1$ & $1, ?$ & $1, ?$ \\
\hline M-092-2 & 2 & $1,2, ?$ & $1,2,2, ?$ & $1,4,3,2$ & $1,2,1$ & $1,2,2,2$ \\
\hline M-092-2 & 3 & $1,2,2, ?, 1$ & - & - & - & - \\
\hline M-092-2 & 4 & - & - & - & - & - \\
\hline M-092-2 & 7 & - & - & - & - & - \\
\hline M-093-3 & 1 & $1,2,2,1$ & $1,2, ?, 2$ & - & - & $1,2,2,1$ \\
\hline M-094-07 & 1 & $1,2,2,1$ & $1,2,2,2$ & $1,2, ?$ & $1,2, ?, 1$ & - \\
\hline M-094-10 & 1 & $1,2,2,2$ & $1,2, ?$ & $1,2,3,2,2$ & 1,2,?,1 & - \\
\hline M-094-10 & 2 & - & - & - & $1,2, ?$ & $1,2, ?$ \\
\hline M-094-11 & 2 & $1,2,2,1$ & $1,2,2,1$ & $1,2,2,2,1$ & $1,2, ?, 1$ & 1,2,?,1 \\
\hline M-094-11 & 1 & $1,2,2,1,2$ & $1,2,2, ?, 2$ & $1,2,3, ?, 2$ & - & $1,2,2, ?$ \\
\hline M-095-01 & 1 & - & - & - & - & - \\
\hline M-095-01 & 2 & - & - & - & - & - \\
\hline M-095-07 & 3 & - & $1,2,2,1$ & $1,2, ?$ & $1,2, ?, 1$ & $1,2,2,2$ \\
\hline M-095-07 & 4 & $1,2,2,2$ & $1,2,1,1$ & $1,2,3,2,1$ & $1,2,1,1$ & $1,2,2,2$ \\
\hline M-095-07 & 6 & $1,2,2,1$ & $1,2,1,1$ & 1,2,3,?,1 & $1,2,2,1$ & $1,2,2,1$ \\
\hline M-095-07 & 2 & $1,2, ?, 1$ & $1,2,1,1$ & $1,2, ?$ & $1,2, ?, 1$ & $1,2, ?, 1$ \\
\hline M-095-07 & 1 & - & - & - & - & - \\
\hline M-095-07 & 5 & $1,2,1,1$ & $1,2,1,1$ & - & - & - \\
\hline M-095-07 & 7 & - & - & - & - & - \\
\hline M-095-10 & 4 & $1,2,2,1$ & - & $1,2,3,1,1$ & - & - \\
\hline M-095-10 & 5 & $1,2,1$ & - & $1,2, ?$ & $1,2,2$ & $1,2,1,1$ \\
\hline M-095-10 & 10 & - & 1,2,?,?,1 & $1,2,2,1$ & - & $1,2, ?, 1$ \\
\hline M-095-10 & 1 & $1,2, ?, 1$ & $1,2, ?, 2$ & $1,2,3,2,1$ & - & - \\
\hline M-095-10 & 2 & - & $1,2,2,2$ & $1,2,3,2,1$ & $1,2,2,2$ & $1,2,2,2$ \\
\hline M-095-10 & 3 & $1,2,2,2,2$ & $1,2,2,2,2$ & $1,2,3,3,2$ & - & $1,2,2,2,1$ \\
\hline M-095-10 & 6 & - & - & - & - & - \\
\hline M-095-10 & 7 & - & - & $1,2,2, ?, 1$ & - & - \\
\hline M-095-10 & 8 & - & - & - & - & - \\
\hline
\end{tabular}




\begin{tabular}{|c|c|c|c|c|c|c|}
\hline Locality & Specimen \# & A-B & $\mathrm{B}-\mathrm{C}$ & C-D & D-E & E-A \\
\hline M-095-10 & 9 & - & - & - & - & - \\
\hline M-095-11 & 1 & $1,2,2,2, ?$ & - & $1,2, ?$ & $1,2, ?$ & $1,2,2,1$ \\
\hline M-095-16 & 1 & - & - & - & - & - \\
\hline M-095-19 & 1 & $1,2, ?, 1$ & $1,2, ?$ & $1,3,2, ?$ & $1,2,2,1$ & $1,2,2,1$ \\
\hline M-095-19 & 2 & $1,2,2,1$ & - & $1,2, ?$ & $1,2, ?, 1$ & $1,2,2,1$ \\
\hline M-095-19 & 3 & $1,2,1,1$ & - & $1,2,3,2,1$ & - & $1,2, ?$ \\
\hline M-095-19 & 4 & - & - & - & - & - \\
\hline M-095-19 & 5 & - & - & - & - & - \\
\hline M-095-20 & 1 & $1,2,1,1$ & $1,2,1,1$ & $1,2,2,2$ & $1,2,1,1$ & $1,2,2,1$ \\
\hline M-095-29 & 1 & $1,2,2,1$ & $1,2,1,1$ & $1,2,2,1$ & $1,2,1$ & $1,2,1$ \\
\hline M-095-29 & 2 & $1,2,2,1$ & $1,2,1$ & $1,2,2,1$ & $1,2,2,1$ & $1,2,2,1$ \\
\hline M-095-29 & 3 & $1,2,2,1$ & $1,2,2,1$ & $1,2,3,2,1$ & $1,2, ?$ & $1,2,2,1$ \\
\hline M-095-29 & 4 & $1,2, ?$ & $1,2, ?$ & $1,2,2,1$ & $1,2, ?, 1$ & $1,2, ?, 1$ \\
\hline M-095-29 & 5 & $1,2, ?$ & $1,2, ?$ & 1,2,?,1 & 1,2,?,1 & $1,2, ?$ \\
\hline M-095-29 & 6 & $1,2,2,1$ & $1,2, ?$ & $1,2,3,2$ & $1,2,2,1$ & $1,2, ?$ \\
\hline M-095-29 & 7 & $1,2,2,1$ & $1,2,2,1$ & $1,2,3, ?$ & $1,2,2,1$ & $1,2,2,1$ \\
\hline M-095-29 & 8 & $1,2,1, ?$ & $1,2,1,2$ & $1,2,3, ?, 2$ & $1,2,1,1$ & $1,2,2,1$ \\
\hline M-095-29 & 10 & $1,2,2,1$ & 1,2,?,1 & $1,2,3, ?$ & $1,2, ?, 1$ & $1,2, ?, 1$ \\
\hline M-095-29 & 12 & $1,2,2,2$ & $1,2, ?$ & $1,2,2,2,2$ & $1,2, ?$ & $1,2, ?, 2$ \\
\hline M-095-29 & 19 & $1,2,2,1$ & $1,2,2,1$ & $1,2,3,2,1$ & $1,2,2,1$ & $1,2,2,1$ \\
\hline M-095-29 & 20 & $1,2, ?, 1$ & 1,2,?,2 & 1,2,3,? & - & $1,2, ?$ \\
\hline M-095-29 & 21 & $1,2,1,2$ & $1,2,1,1$ & $1,2,3,1$ & $1,2,2,1$ & $1,2,1,1$ \\
\hline M-095-29 & 22 & $1,2,2,1$ & $1,2,1,1$ & $1,2,2,1,1$ & - & - \\
\hline M-095-29 & 23 & $1,2,1,1$ & $1,2,1,1$ & $1,2,3, ?$ & $1,2,2,1$ & $1,2,2,1$ \\
\hline M-095-29 & 24 & $1,2, ?, 1$ & $1,2,2,2$ & $1,2, ?$ & 1,2,?,2 & $1,2, ?, 1$ \\
\hline M-095-29 & 25 & $1,2,2,1$ & $1,2,2,1$ & $1,2,3,1$ & $1,2,2,1$ & $1,2,2,1$ \\
\hline M-095-29 & 26 & - & - & $1,2,3,2,1$ & $1,2,2,2$ & $1,2, ?$ \\
\hline M-095-29 & 27 & $1,2,2,1$ & $1,2,2,1$ & $1,2, ?$ & - & - \\
\hline M-095-29 & 28 & $1,2,2$ & $1,2,1$ & $1,2,4,2, ?$ & $1,2,2$ & $1,2,1$ \\
\hline M-095-29 & 30 & - & $1,2,2,1$ & $1,2,3,2,1$ & - & - \\
\hline M-095-29 & 31 & $1,2,2,1$ & - & $1,2,3,2,1$ & - & $1,2, ?$ \\
\hline M-095-29 & 32 & - & $1,2,2, ?$ & $1,2,3,2,1$ & $1,2,2,1$ & $1,2,2,1$ \\
\hline M-095-29 & 11 & $1,2,2,2$ & $1,2,2,1$ & $1,2,3,2$ & $1,2,2,2$ & $1,2, ?, 1$ \\
\hline M-095-29 & 15 & $1,2, ?$ & - & $1,2,3,2,1$ & $1,2,2,1$ & - \\
\hline M-095-29 & 17 & $1,2,2, ?$ & $1,2,2,1,1$ & $1,3,4,2,1$ & - & - \\
\hline M-095-29 & 9 & - & - & - & - & - \\
\hline M-095-29 & 13 & - & - & - & 1,2,?,1 & $1,2,1,1$ \\
\hline M-095-29 & 14 & - & 1,2,?,1 & $1,2, ?$ & - & - \\
\hline M-095-29 & 16 & - & - & - & - & - \\
\hline M-095-29 & 18 & - & - & - & - & - \\
\hline M-095-29 & 29 & - & - & - & - & - \\
\hline
\end{tabular}




\begin{tabular}{|c|c|c|c|c|c|c|}
\hline Locality & Specimen \# & A-B & B-C & C-D & D-E & E-A \\
\hline M-095-29 & 33 & $1,2,2,1$ & - & - & - & - \\
\hline M-095-29 & 34 & - & - & - & - & - \\
\hline M-097-1 & 1 & - & - & - & - & - \\
\hline M-099-1 & 1 & - & $1,2,2,1$ & $1,2,3, ?, 1$ & $1,2, ?$ & $1,2, ?$ \\
\hline M-100-1 & 1 & $1,2, ?, 1$ & - & - & - & - \\
\hline M-100-2 & 1 & $1,2,2,2$ & $1,2, ?, 2$ & $1,2,2,1$ & $1,2, ?, 2$ & $1,2, ?$ \\
\hline M-100-2 & 2 & $1,2,2,1$ & $1,2,2,1$ & $1,2,3,2,2$ & $1,2, ?, 1$ & $1,2,2,1$ \\
\hline M-100-2 & 3 & - & - & - & - & - \\
\hline M-100-2 & 4 & - & - & - & - & - \\
\hline M-102-1 & 2 & $1,2,2,2,1$ & $1,2,2,1, ?$ & $1,3,3,1,1$ & $1,2,2,1$ & $1,2,2,1,1$ \\
\hline M-102-1 & 1 & $1,2, ?, 1$ & - & - & - & - \\
\hline M-151-1 & 1 & $1,2, ?$ & $1,2,2,2$ & $1,2, ?$ & $1,2,2,2$ & $1,2, ?, 2$ \\
\hline M-154-1 & 1 & $1,2,2,1,1$ & $1,2, ?$ & $1,2,3, ?$ & - & $1,2,2,1$ \\
\hline M-154-1 & 2 & - & - & - & - & - \\
\hline M-155-1 & 2 & $1,2,2,1$ & $1,2,2,1$ & $1,2,3,2,1$ & $1,2, ?, 1$ & $1,2, ?, 1$ \\
\hline M-155-1 & 3 & $1,2, ?, 1$ & - & 1,2,3,?,1 & - & $1,2, ?$ \\
\hline M-155-1 & 1 & $1,2, ?, 2$ & $1,2,2,1$ & - & $1,2,2,1$ & - \\
\hline M-158-02 & 1 & - & - & - & - & - \\
\hline M-158-02 & 2 & - & - & - & - & - \\
\hline M-158-05 & 1 & $1,2,1,1$ & $1,2,1$ & $1,2,2,1$ & $1,2,1,1$ & $1,2,1,1$ \\
\hline M-158-05 & 2 & $1,2, ?$ & $1,2,1,1$ & $1,2, ?$ & $1,2, ?, 1$ & $1,2, ?, 1$ \\
\hline M-158-05 & 3 & $1,2,2,1$ & $1,2, ?$ & $1,2,3,1,2$ & $1,2,1, ?$ & $1,2,1,1$ \\
\hline M-158-05 & 5 & - & - & $1,2,2, ?$ & $1,2,1,1$ & $1,2, ?$ \\
\hline M-158-05 & 4 & $1,2, ?$ & $1,2, ?$ & $1,2,3, ?$ & - & $1,2, ?$ \\
\hline M-158-06 & 2 & $1,2,2, ?$ & $1,2, ?$ & $1,3, ?$ & $1,2,2,1$ & $1,2,2,2$ \\
\hline M-158-06 & 1 & - & - & - & - & - \\
\hline M-158-07 & 1 & $1,2,2,2$ & - & - & - & - \\
\hline M-158-08 & 1 & $1,2,2,1$ & $1,2, ?$ & $1,2,3,1,1$ & 1,2,?,1 & $1,2,2,1$ \\
\hline M-158-08 & 4 & $1,2,1$ & - & $1,2, ?, 1$ & - & - \\
\hline M-158-08 & 7 & $1,2, ?$ & $1,2,1$ & $1,2,3, ?$ & - & - \\
\hline M-158-08 & 9 & - & $1,2,2,1$ & $1,2,2, ?$ & - & - \\
\hline M-158-08 & 2 & $1,2, ?$ & $1,2, ?$ & $1,2, ?$ & - & - \\
\hline M-158-08 & 3 & - & - & - & - & - \\
\hline M-158-08 & 5 & - & - & - & - & - \\
\hline M-158-08 & 6 & $1,2,2,2$ & - & - & - & - \\
\hline M-158-08 & 8 & - & - & - & - & - \\
\hline M-158-08 & 10 & $1,2,2,2$ & $1,2, ?$ & $1,2,3, ?$ & - & - \\
\hline M-158-12 & 1 & $1,2,2,1$ & $1,2, ?, 1$ & $1,2, ?$ & - & $1,2, ?, 2$ \\
\hline M-158-12 & 4 & $1,2,2,1$ & $1,2,2,1,1$ & $1,2,3,2,1$ & $1,2,2,1$ & $1,2,2,1$ \\
\hline M-158-12 & 7 & - & $1,2,2,2$ & $1,2,2,1,1$ & $1,2,2,2$ & - \\
\hline M-158-12 & 2 & - & $1,2,2,2$ & $1,2,3,2,1$ & $1,2,2,2$ & - \\
\hline
\end{tabular}




\begin{tabular}{|c|c|c|c|c|c|c|}
\hline Locality & Specimen \# & A-B & $\mathrm{B}-\mathrm{C}$ & C-D & D-E & E-A \\
\hline M-158-12 & 3 & 1,2,?,2 & $1,2,2,1$ & $1,2,2,2$ & $1,2,2,2$ & $1,2,2,2$ \\
\hline M-158-12 & 5 & $1,2,2,2,1$ & $1,2,2,2,1$ & $1,1,2,3,2,1$ & $1,2,2,2,1$ & $1,2,2,2,1$ \\
\hline M-158-12 & 6 & $1,2, ?, 1$ & - & $1,2,3,2,2$ & $1,2,2,2$ & $1,2, ?, 2$ \\
\hline M-158-12 & 8 & 1,2,?,2 & $1,2, ?, 2$ & 1,2,?,?,2 & $1,2, ?$ & $1,2, ?$ \\
\hline M-158-12 & 10 & $1,2,2,2$ & $1,2, ?$ & $1,2,3,2,2$ & $1,2,2,2$ & $1,2,2,2$ \\
\hline M-158-12 & 9 & $1,2,2, ?, 1$ & $1,2,2,1,1$ & - & - & - \\
\hline M-158-14 & 2 & - & - & $1,2,3,1$ & $1,2, ?, 1$ & - \\
\hline M-158-14 & 3 & $1,2, ?$ & $1,2,2, ?$ & $1,2,3,1,1$ & $1,2,2,1$ & $1,2,2,1$ \\
\hline M-158-14 & 5 & $1,2,1$ & $1,2,1$ & $1,2,2,1$ & - & - \\
\hline M-158-14 & 1 & $1,2,2,2$ & $1,2,2,2$ & $1,2,4, ?$ & - & $1,2,2,2$ \\
\hline M-158-14 & 4 & - & - & - & - & - \\
\hline M-158-14 & 6 & - & - & - & - & - \\
\hline M-158-15 & 1 & $1,2,2,2,2$ & $1,2,2,2,1$ & $1,2,3,2,1$ & $1,2,2,2,2$ & $1,2,2,2,2$ \\
\hline M-159-2 & 1 & - & $1,2, ?$ & $1,2,2, ?, 2$ & $1,2,2,2$ & $1,2,2,2$ \\
\hline FC-11 & 1 & - & - & $1,2,3, ?, 1$ & - & - \\
\hline InUni-04 & 1 & $1,2,2,1$ & $1,2,2, ?$ & $1,2,3,2$ & $1,2,1,1$ & $1,2,2,1$ \\
\hline InUni-04 & 4 & - & $1,2,2,1$ & $1,2,2,1$ & $1,2, ?$ & $1,2,2,1$ \\
\hline InUni-04 & 6 & - & - & 1,2,3,1 & $1,2,1$ & - \\
\hline InUni-04 & 3 & $1,2,1$ & $1,2, ?$ & $1,2,3,2$ & $1,2,1$ & $1,2,1$ \\
\hline InUni-04 & 2 & - & - & - & - & - \\
\hline InUni-04 & 5 & - & - & - & - & - \\
\hline InUni-04 & 7 & - & - & - & - & - \\
\hline InUni-04 & 8 & - & - & - & - & - \\
\hline InUni-09 & 1 & - & - & - & - & - \\
\hline InUni-13 & 2 & $1,2,1,1$ & $1,2,2,1$ & $1,2,3,2, ?$ & - & 1,2,?,1 \\
\hline InUni-13 & 3 & $1,2,2,1$ & $1,2,2,1$ & $1,2,3,1$ & $1,2,2,1$ & $1,2,2,1$ \\
\hline InUni-13 & 7 & $1,2,2$ & $1,2,2,1$ & $1,2,2,2,1$ & - & $1,2, ?$ \\
\hline InUni-13 & 1 & $1,2,2$ & $1,2,1$ & $1,3,2$ & $1,2,2$ & $1,2,2$ \\
\hline InUni-13 & 5 & $1,2,1$ & $1,2,1$ & $1,2,1,1$ & $1,2,1$ & $1,2,1$ \\
\hline InUni-13 & 4 & - & - & - & - & - \\
\hline InUni-13 & 6 & - & - & - & - & - \\
\hline InUni-21 & 1 & $1,2,2,2$ & $1,2,3, ?$ & - & - & - \\
\hline InUni-23 & 2 & $1,2,2, ?$ & $1,2, ?$ & $1,2,3,2, ?$ & - & $1,2, ?$ \\
\hline InUni-23 & 1 & $1,2, ?$ & $1,2,1,1$ & - & - & - \\
\hline InUni-30 & 1 & - & - & $1,2,2, ?$ & $1,2,2,1$ & - \\
\hline InUni-30 & 2 & $1,2, ?, 1$ & $1,2,2,1$ & $1,3,2, ?$ & - & - \\
\hline InUni-30 & 3 & 1,2,?,2 & $1,2,2,2$ & $1,2,3,1$ & - & $1,2, ?$ \\
\hline InUni-30 & 4 & $1,2,2,2$ & - & $1,2,3,1,1$ & $1,2,2,1$ & $1,2,2, ?$ \\
\hline InUni-30 & 5 & $1,2,2,2$ & $1,2,2,2$ & $1,2,2, ?, 1$ & - & - \\
\hline InUni-32 & 1 & $1,2,2,1$ & $1,2,2,1$ & $1,2,3,3,1,1$ & $1,2,2,1,1$ & $1,2,2,1,1$ \\
\hline InUni-36 & 2 & $1,2,2,1$ & $1,2,2,1$ & $1,2,2,1,1$ & $1,2,2,1$ & $1,2,2,1$ \\
\hline
\end{tabular}




\begin{tabular}{|c|c|c|c|c|c|c|}
\hline Locality & Specimen \# & A-B & $\mathrm{B}-\mathrm{C}$ & C-D & D-E & E-A \\
\hline InUni-36 & 3 & $1,2,2, ?, 1$ & $1,2,2, ?, 1$ & $1,2,3,2, ?, 1$ & $1,2,2, ?$ & $1,2,2, ?, 1$ \\
\hline InUni-36 & 4 & $1,2, ?$ & $1,2, ?$ & $1,2,3,2,1$ & $1,2,2,1$ & $1,2,2, ?, 1$ \\
\hline InUni-36 & 5 & $1,2, ?$ & $1,2, ?$ & $1,2,3,2$ & - & $1,2, ?$ \\
\hline InUni-36 & 6 & $1,2,2,1$ & $1,2,2,1$ & $1,2,3,2,1$ & $1,2,2,1$ & $1,2,2,1$ \\
\hline InUni-36 & 7 & - & $1,2,2,1$ & $1,2, ?, ?, 1$ & - & - \\
\hline InUni-36 & 8 & $1,2,2,1$ & - & $1,2,3, ?, 1$ & $1,2,2,1$ & $1,2,2,1$ \\
\hline InUni-36 & 9 & - & $1,2,2,1$ & $1,2,3,2,2$ & $1,2,2,2,1$ & - \\
\hline InUni-36 & 10 & - & - & $1,2,3, ?$ & $1,2, ?$ & $1,2, ?, 2$ \\
\hline InUni-36 & 11 & - & $1,2,2, ?, 1$ & $1,2,3,2,1$ & $1,2,2,2,2$ & $1,2,2,2,1$ \\
\hline InUni-36 & 1 & $1,2,1,1$ & - & - & - & - \\
\hline InUni-37 & 1 & $1,2,1$ & $1,2,1$ & $1,2, ?, 1$ & $1, ?, 1$ & $1,3,1$ \\
\hline InUni-37 & 2 & $1,2, ?, 1$ & $1,2, ?$ & $1,2,3,1$ & $1,2,2,1$ & $1,2,2,1$ \\
\hline InUni-38 & 1 & $1,2,1,1$ & $1,2,1$ & $1,2,1,1$ & $1,2,1$ & $1,2, ?, 1$ \\
\hline InUni-42 & 1 & $1,2, ?$ & - & $1,2,3,1$ & $1,2,2,1$ & $1,2,1,1$ \\
\hline InUni-42 & 2 & - & 1,?,?,2 & $1,2,2,1$ & - & - \\
\hline InUni-42 & 5 & $1,2,2,1$ & $1,2,2,2$ & 1,2,3,?,2 & $1,2,2,1$ & $1,2,2,1$ \\
\hline InUni-42 & 6 & $1,2,2,1$ & $1,2,2,1$ & $1,2,3, ?$ & $1,2,2,1$ & $1,2,2,1$ \\
\hline InUni-42 & 8 & $1,2, ?$ & $1,2,1$ & $1,2,3,2,1$ & $1,2,2,1$ & $1,2,1$ \\
\hline InUni-42 & 3 & - & - & 1,2,3,2, & - & - \\
\hline InUni-42 & 4 & - & - & $1,2,3,2, ?$ & $1,2,2,1$ & - \\
\hline InUni-42 & 7 & - & - & $1,3,3, ?$ & 1,2,?,1 & - \\
\hline InUni-42 & 9 & - & - & - & - & - \\
\hline InUni-42 & 10 & $1,2, ?$ & $1,2, ?$ & $1,2, ?$ & $1,2, ?, 1$ & $1,2,2, ?, 1$ \\
\hline InUni-42 & 11 & 1,2,?,1 & $1,2, ?$ & $1,2,2,2,1$ & - & - \\
\hline InUni-43 & 2 & $1,2, ?, 1$ & - & $1,2, ?$ & $1,2,2,1$ & $1,2, ?$ \\
\hline InUni-43 & 3 & $1,2, ?$ & $1,2, ?$ & $1,2,3,1$ & $1,2, ?$ & $1,2, ?$ \\
\hline InUni-43 & 5 & $1,2,2$ & $1,2, ?$ & $1,2, ?$ & - & $1,2,2$ \\
\hline InUni-43 & 7 & $1,2,2,2$ & 1,2,?,1 & $1,2,3, ?$ & $1,2,2,1$ & $1,2, ?$ \\
\hline InUni-43 & 8 & $1,2, ?, ?, 1$ & $1,2, ?$ & $1,2,3,1$ & - & $1,2,2,1$ \\
\hline InUni-43 & 4 & $1,2,2,2$ & $1,2,2,2$ & $1,2,3,2,2$ & $1,2,2, ?$ & $1,2,2,2$ \\
\hline InUni-43 & 1 & $1,2, ?$ & $1,2, ?$ & $1,2, ?$ & $1,2, ?$ & $1,2, ?$ \\
\hline InUni-43 & 6 & - & - & - & - & - \\
\hline L-13,559 & 1 & $1,2, ?$ & $1,2,1,1$ & $1,3,2,2,1$ & $1,2, ?$ & $1,2,1,1$ \\
\hline L-13,578 & 2 & 1,2 & - & $1,2,1,1$ & - & $1,2,1$ \\
\hline L-13,578 & 1 & - & - & - & - & - \\
\hline L-13,578 & 3 & $1,2,2,1$ & $1,2,1,1$ & - & - & - \\
\hline L-13,578 & 4 & - & - & - & - & - \\
\hline L-13,578 & 5 & $1,2, ?$ & $1,2,2, ?$ & - & $1,2,2, ?$ & $1,2,2, ?$ \\
\hline L-13,578 & 6 & - & - & - & - & - \\
\hline L-13,803 & 1 & $1,2,2,1$ & - & - & - & - \\
\hline L-13,803 & 2 & - & - & - & - & - \\
\hline
\end{tabular}




\begin{tabular}{ccccccc}
\hline \hline Locality & Specimen \# & A-B & B-C & C-D & D-E & E-A \\
\hline L-13,998 & 1 & $1,2, ?$ & - & - & - & $1,2,2,2$ \\
L-13,998 & 2 & $1,2, ?$ & $1,2, ?$ & $1,2, ?, ?, 1$ & - & $1,2, ?$ \\
L-13,998 & 3 & - & $1,2, ?$ & $1,2, ?, ?, 1$ & - & $1,2,2,1$ \\
L-13,998 & 4 & - & - & $1,2,3, ?$ & - & - \\
L-13,998 & 5 & - & - & - & - & - \\
L-13,998 & 6 & - & $1,2,2, ?$ & $1,3, ?$ & - & - \\
L-13,998 & 7 & - & - & - & - & - \\
L-13,998 & 8 & - & - & - & - & - \\
L-13,998 & 9 & - & - & - & - & - \\
L-13,998 & 10 & - & - & - & - & - \\
L-14,022 & 1 & $1,2,2,1$ & - & - & - & - \\
L-14,028 & 1 & $1,2, ?, 1$ & - & $1,2, ?$ & $1,2,1,1$ & $1,2, ?, 1$ \\
L-14,028 & 2 & $1,2,2,1$ & - & $1,2,3, ?$ & $1,2,2,1$ & $1,2,2,2$ \\
L-14,028 & 3 & $1,2, ?$ & $1,2,2, ?$ & $1,2, ?$ & $1,2, ?$ & $1,2, ?$ \\
L-14,028 & 5 & $1,2, ?, 1$ & - & $1,2,3,2, ?$ & $1,2, ?, 1$ & $1,2, ?$ \\
L-14,028 & 6 & $1,2, ?$ & $1,2,2$ & - & $1,2, ?, 2$ & $1,2,1$ \\
L-14,028 & 4 & - & - & $1,2,3,2,1$ & - & - \\
L-14,028 & 7 & - & - & - & - & - \\
L-14,077 & 1 & $1,2, ?$ & $1,2, ?$ & $1,2,3, ?$ & $1,2, ?$ & $1,2, ?$ \\
Unk-1 & 1 & - & - & - & - & - \\
Unk-3 & 1 & $1,2, ?$ & $1,2, ?$ & $1,2,3,2,2$ & $1,2, ?$ & $1,2, ?$ \\
Unk-3 & 2 & $1,2,2,2,2$ & - & - & - & - \\
USNM-2 & 1 & $1,2, ?, 1$ & $1,2, ?, 1$ & - & - & - \\
\hline
\end{tabular}




\begin{tabular}{|c|c|c|c|c|c|c|c|}
\hline Smith. \# & Specimen \# & A-B & $\mathrm{B}-\mathrm{C}$ & D-E & E-A & Anal & Species \\
\hline S4622 & 1 & $1,2,2,2$ & $1,2,2,2$ & $1,2,2,2$ & $1,2,2,2$ & $1,2,3, ?, 2$ & mammillatus \\
\hline S4621 & 1 & $1,2,2,2$ & $1,2,2,1$ & $1,2,2,1$ & $1,2,2,2$ & $1,2,2,2,1$ & mammillatus \\
\hline S4623 & 1 & $1,2,2, ?$ & $1,1,1,1$ & $1,2,2,1$ & $1,2,2,1$ & $1,3,2,1$ & mammillatus \\
\hline S4619 & 1 & $1,2,2,1$ & - & $1,2,2,1$ & $1,2,2,1$ & $1,2,2,1$ & mammillatus \\
\hline S4619 & 2 & $1,2,2,1$ & $1,2,2,1$ & $1,2,2,1$ & $1,2,2,1$ & $1,2,3,2,1$ & mammillatus \\
\hline S4619 & 3 & $1,2,2$ & $1,2,2,2$ & $1,2,2,2$ & $1,2,2,2$ & $1,2, ?, 1$ & mammillatus \\
\hline S4619 & 4 & - & - & - & - & $1,2,2, ?$ & mammillatus \\
\hline S4618 & 1 & $1,2,2,2,1$ & - & $1,2,2,1$ & $1,2,2,2$ & $1,2, ?$ & mammillatus \\
\hline S4618 & 2 & $1,2,2,2$ & $1,2,2,1$ & $1,2,2,2$ & $1,2, ?$ & $1,2,3,2,2$ & mammillatus \\
\hline S4618 & 3 & - & $1,2, ?, 1$ & $1,2, ?, 1$ & $1,2, ?$ & $1,2,1,1$ & mammillatus \\
\hline S4618 & 4 & - & - & - & - & $1,2, ?$ & mammillatus \\
\hline S4618 & 5 & $1,2,2$ & $1,2, ?$ & $1,2,2$ & $1,2,2$ & $1,2,2,2$ & mammillatus \\
\hline S4618 & 6 & $1,2,2,1$ & $1,2, ?, 1$ & $1,2,2,1$ & $1,2,2,1$ & $1,2,2, ?$ & mammillatus \\
\hline S4618 & 7 & $1,2,2,1$ & $1,2,1$ & $1,2,1,1$ & $1,2,2, ?$ & $1,2,2,2$ & mammillatus \\
\hline S4618 & 8 & - & - & - & - & - & mammillatus \\
\hline S4618 & 9 & $1,2,2,1,1$ & $1,2,2,1$ & $1,2,2,2,1$ & - & $1,2,3,2,2$ & mammillatus \\
\hline S4618 & 10 & $1,2, ?, 1$ & $1,2,1,2$ & - & - & $1,2,2,2$ & mammillatus \\
\hline 435908 & 1 & $1,2,2,2$ & $1,2,2,2$ & $1,2,2,2$ & $1,2,2,2$ & $1,2,3,2$ & dalyanus \\
\hline 435904 & 1 & $1,2,2,1$ & $1,2,2,1$ & $1,2,2,1$ & $1,2,2,1$ & $1,2,2,1$ & dalyanus \\
\hline 435907 & 1 & $1,2,2,1$ & $1,2,2,1,2$ & $1,2,2,2,1$ & $1,2,2,2,1$ & $1,2,3,2,1$ & dalyanus \\
\hline 435905 & 1 & $1,2,2$ & $1,2,1$ & $1,2,1$ & $1,2,1$ & $1,2,2, ?$ & dalyanus \\
\hline 435906 & 1 & $1,2,1$ & $1,2, ?$ & $1,2,1$ & $1,2,2,1$ & $1,2,1,1$ & dalyanus \\
\hline 435912 & 1 & $1,2,2,2$ & $1,2,2, ?$ & $1,2,2,2,1$ & $1,2,2,2,2$ & $1,2,3,3,2$ & dalyanus \\
\hline 160619 & 1 & $1,2,2,2,2$ & $1,2,2,2,1$ & $1,2,2,2,1$ & $1,2,2,2$ & $1,2,2,2,1$ & dalyanus \\
\hline 435910 & 1 & $1,2,2,2$ & $1,2,2,2$ & $1,2,2,2$ & $1,2,2,2$ & $1,2,3,2,2$ & dalyanus \\
\hline 160618 & 1 & $1,2,2,1$ & $1,2,2$ & $1,2,2,1$ & $1,2,2,1$ & $1,2,3,2,2$ & dalyanus \\
\hline 435911 & 1 & $1,2,1$ & $1,2,1,1$ & $1,2,2$ & $1,2,1,2$ & $1,2,3,2,2$ & dalyanus \\
\hline 435923 & 1 & $1,2,1$ & $1,2,1$ & $1,2,1$ & $1,2,1$ & $1,2,3,2$ & dalyanus \\
\hline 435903 & 1 & - & $1,2,2,2$ & $1,2,1,2$ & - & $1,2,2,2$ & dalyanus \\
\hline 435898 & 1 & $1,2,1$ & $1,2,1$ & $1,2,1$ & $1,2,2,2$ & $1,2,2,1$ & dalyanus \\
\hline 160604 & 1 & $1,2,1$ & $1,2,1$ & $1,2,1$ & - & $1,2,2,1$ & dalyanus \\
\hline 160617 & 1 & $1,2,2,1$ & $1,2,2,1$ & $1,2,2,2$ & $1,2,2,2,1$ & $1,2,2,2,1$ & dalyanus \\
\hline 435909 & 1 & $1,2,2,1$ & $1,2,2,1$ & $1,2,2,1$ & $1,2,2,1$ & $1,2,3,1,1$ & dalyanus \\
\hline 435895 & 1 & $1,2,1,1$ & $1,2,1$ & - & $1,2,1$ & $1,2,2,1$ & dalyanus \\
\hline 435899 & 1 & - & - & - & - & - & dalyanus \\
\hline 435897 & 1 & $1,2,2, ?$ & $1,2,1,2$ & $1,2,1,1$ & $1,2,2,2$ & $1,2,3,1$ & dalyanus \\
\hline 435900 & 1 & $1,2,2,2$ & $1,2,1$ & $1,2,2,1$ & $1,2,1,1$ & $1,2,3,2,1$ & dalyanus \\
\hline 435901 & 1 & $1,2,2,2,1$ & $1,2,2,2,1$ & $1,2,2,2,1$ & $1,2,2,2,1$ & $1,2,3,3,2$ & dalyanus \\
\hline 448071 & 1 & $1,2,3,1, ?$ & $1,2,3,2, ?$ & $1,2,2,1,1$ & $1,2,2,1$ & $1,2,4,5,2$ & dalyanus \\
\hline 160602 & 1 & $1,2,2,1$ & $1,2,2,2$ & $1,2,2,1$ & $1,2, ?$ & $1,2,2,1,1$ & dalyanus \\
\hline 114695 & 1 & $1,2,1,2$ & $1,2,2,2$ & $1,2,2,2$ & $1,2,2,2$ & $1,2,3,2,2$ & mammillatus \\
\hline
\end{tabular}




\begin{tabular}{cccccccc}
\hline \hline Smith. \# & Specimen \# & A-B & B-C & D-E & E-A & Anal & Species \\
\hline S4620 & 1 & $1,2,2,2$ & $1,2,1,2$ & $1,2,2,2$ & $1,2,2,1$ & $1,2,3,2,2$ & mammillatus \\
S4620 & 2 & $1,2,2,1$ & $1,2,2,1,2$ & $1,2,2,1,1$ & $1,2,2,2$ & $1,2,2,3,2$ & mammillatus \\
S4620 & 3 & $1,2,2$ & $1,2,2,2$ & $1,2,2,2$ & $1,2,2,2$ & $1,2,3,2,2$ & mammillatus \\
S4620 & 4 & $1,2,2,1$ & $1,2,2,2$ & - & $1,2,2,1$ & $1,2,3,1,1$ & mammillatus \\
S1218 & 1 & $1,2,2,1$ & $1,2,2,2$ & $1,2,2,2$ & $1,2,2,2$ & $1,2,2,2,2$ & mammillatus \\
S1218 & 2 & $1,2,2,2,2$ & $1,2,2,2,2$ & $1,2,2,2,2$ & $1,2,2,2,2$ & $1,2,3,3,3,3$ & mammillatus \\
S1218 & 3 & $1,2,2,2,1$ & $1,2,1,2,1$ & $1,2,2,2,1$ & $1,2,2,2,1$ & $1,2,4, ?$ & mammillatus \\
118032 & 1 & $1,2,2,1$ & $1,2,2,1$ & $1,2,2,1$ & $1,2,2,2$ & $1,2,3,2,2$ & mammillatus \\
118028 & 1 & $2,2,2,1$ & $1,2,2,2$ & $1,2,2$ & $1,2,1$ & $1,2,2,2,1$ & mammillatus \\
118028 & 2 & $1,2,2,1$ & $1,2,2,1$ & $1,2,2,1$ & $1,2,2,1$ & $1,2,2,1,1$ & mammillatus \\
118028 & 3 & $1,2,2,1$ & $1,2,2,1$ & $1,2,1,1$ & $1,2,2,1$ & $1,2,3,1,2$ & mammillatus \\
118028 & 4 & $1,2,1,1$ & $1,2,2,1$ & $1,2,2,1$ & $1,2,2,1$ & $1,2,3,1$ & mammillatus \\
118028 & 5 & $1,2,2,2$ & $1,2,2,2$ & $1,2,2,2$ & $1,2,2,2$ & $1,2,3,2$ & mammillatus \\
118030 & 1 & $1,2,2,2$ & $1,2,2,2$ & $1,2,2,2$ & $1,2,2,2$ & $1,3,2,2$ & mammillatus \\
118030 & 2 & $1,2,2,1$ & $1,2,1,2$ & $1,2,2,2$ & $1,2,2,2$ & $1,2,3,2,1$ & mammillatus \\
118026 & 1 & $1,2,2,2$ & $1,2,2,1,2$ & $1,2,2,1$ & $1,2,2,2$ & $1,2,3,2,2$ & mammillatus \\
118026 & 2 & $1,2,2,2$ & $1,2,2, ?$ & - & - & - & mammillatus \\
118027 & 1 & $1,2,2,2$ & $1,2,2,2$ & $1,2,2,2$ & $1,2,2, ?$ & $1,2,2,2$ & mammillatus \\
118029 & 1 & $1,2,2,1$ & $1,2, ?$ & $1,2, ?$ & $1,2,2,2,1$ & $1,2,2,2,2$ & mammillatus \\
118031 & 1 & $1,2,2$ & $1,2,2,2$ & $1,2,2$ & $1,1,2$ & $1,2,3,2$ & mammillatus \\
\hline
\end{tabular}


ApPENDIX 4 - Characters for phylogenetic analysis

A, Calyx shape: 0 , medium cone; 1 , medium bowl; 2 , high bowl; 3 , low cone; 4, low bowl; 5 , medium globe; 6 , medium cone flared distally; 7 , high cone.

B, Basal circlet: 0, low; 1, high.

C, Number of fixed secundibrachials: 0, zero; 1 , one; 2, two.

D, Highest brachitaxis in vertical wall of calyx: 0 , primibrachitaxis; 1 , secundabrachitaxis; 2 , tertibrachitaxis; 3, quartibrachitaxis.

E, Number of ranges in regular interrays: 0 , two; 1 , three; 2, four; 3, five or more; 4 , ten or more.

F, Regular interrays in contact with tegmen: 0 , yes; 1 , no.

G, Posterior interray in contact with tegmen: 0 , yes; 1 , no.

H, Number of plates above primanal: 0 , three; 1 , two.

I, Fixed interbrachials between half-rays: 0, present; 1, absent.

J, Arms grouped: 0, strongly; 1, no; 2, weakly.

K, Arm lobes: 0, present and extend laterally; 1, absent.

L, Arm lobe length: 0, absent; 1, long; 2, short; 3, medium.

M, Tegmen height vs. calyx: 0, lower; 1 , higher; 2 , same.

N, Tegmen plate sculpture: 0 , nodose; 1 , smooth; 2 , spinose; 3 , proximal spines.

O, Tegmen shape: 0 , low cone; 1 , medium cone; 2 , high cone; 3 , flat cone; 4 , flat inverted bowl;

5, low inverted bowl; 6 , medium inverted bowl.

P, Tegmen interray depressed: 0, no; 1 , yes.

Q, Anal opening: 0, tube present and central; 1 , tube present and eccentric; 2, tube absent and eccentric. 
ApPENDIx 5- Character chart for phylogenetic analysis

\begin{tabular}{|c|c|c|c|c|c|c|c|c|c|c|c|c|c|c|c|c|c|}
\hline \multirow[b]{2}{*}{ Genus } & \multicolumn{17}{|c|}{ Character } \\
\hline & A & $\mathrm{B}$ & $\mathrm{C}$ & $\mathrm{D}$ & $\mathrm{E}$ & $\mathrm{F}$ & $\mathrm{G}$ & $\mathrm{H}$ & $\mathrm{I}$ & $\mathrm{J}$ & $\mathrm{K}$ & $\mathrm{L}$ & $M$ & $\mathrm{~N}$ & $\mathrm{O}$ & $\mathrm{P}$ & $\mathrm{Q}$ \\
\hline Periechocrinus & 7 & 1 & 2 & 2 & 3 & 0 & 0 & 0 & 0 & 0 & 1 & 0 & 0 & 1 & 4 & 0 & 1 \\
\hline Megistocrinus & 1 & 0 & 2 & 2 & 3 & 0 & 0 & 0 & 0 & 2 & 1 & 0 & 0 & $(0,1)$ & 4 & 0 & 1 \\
\hline Eumorphocrinus & 1 & 1 & 2 & 2 & 3 & 0 & 0 & 1 & 1 & 0 & 1 & 0 & 0 & 1 & 5 & 0 & 0 \\
\hline Cytidocrinus & 1 & 1 & 0 & 0 & 2 & 0 & 0 & 1 & 1 & 0 & 1 & 0 & 0 & 2 & 5 & 0 & 0 \\
\hline Physetocrinus & $(0,1)$ & 1 & 1 & $(2,3)$ & 3 & 0 & 0 & 1 & 0 & $(0,2)$ & 1 & 0 & 0 & 1 & $(4,5)$ & 0 & 2 \\
\hline Dialutocrinus & 1 & $(0,1)$ & 1 & 2 & 1 & 0 & 0 & 1 & 0 & $(0,2)$ & 1 & 0 & 0 & 0 & $(0,5)$ & 0 & 0 \\
\hline Thinocrinus & $(0,1)$ & $(0,1)$ & $(1,2)$ & 0 & $(1,2)$ & 0 & 0 & 1 & $(0,1)$ & 0 & 0 & 3 & 0 & $(0,1)$ & $(1,3,4,5)$ & 1 & 0 \\
\hline Abactinocrinus & 1 & 0 & 1 & 0 & 1 & 0 & 0 & 1 & 1 & 0 & 0 & 1 & 0 & 0 & 4 & 1 & 0 \\
\hline Iotacrinus & 4 & 0 & 1 & 0 & 1 & 0 & 0 & 1 & 1 & 0 & 0 & 3 & $(0,1)$ & 0 & 5 & 0 & 1 \\
\hline Aacocrinus & $(0,1)$ & 0 & $(0,1,2)$ & $(0,1)$ & 1 & 0 & 0 & 1 & 1 & 0 & 0 & 2 & 0 & 0 & $(3,5)$ & 0 & 1 \\
\hline Blairocrinus & 3 & 0 & 1 & 0 & 0 & 0 & 0 & 1 & 1 & 0 & 0 & 2 & 1 & $(0,1,3)$ & $(0,1,2,6)$ & 0 & 0 \\
\hline Sampsonocrinus & 1 & 0 & $?$ & 0 & 0 & 0 & 0 & 1 & 0 & 0 & 0 & 2 & 0 & 0 & $(4,5)$ & 1 & 1 \\
\hline Steganocrinus & 0 & 0 & 0 & 0 & 0 & 0 & 0 & 1 & 0 & 0 & 0 & 1 & 2 & 0 & $(4,5)$ & 0 & 1 \\
\hline Actinocrinites & $(0,2)$ & 1 & 1 & $(1,2,3)$ & 1 & 0 & 0 & 1 & $(0,1)$ & 0 & 0 & 1 & 0 & 0 & $(0,3,5)$ & 0 & 0 \\
\hline Cactocrinus & 0 & 0 & 1 & 1 & $(0,1)$ & 1 & 1 & 1 & 0 & 1 & 1 & 0 & $(0,2)$ & $(1,2)$ & $(0,1,5)$ & 0 & 0 \\
\hline Ilmocrinus & $(1,4)$ & 0 & 1 & 2 & 0 & 1 & 1 & 1 & 0 & 1 & 1 & 0 & ? & $?$ & $?$ & 0 & ? \\
\hline Teliocrinus & 0 & 1 & 1 & 2 & 3 & $(0,1)$ & 1 & 1 & 0 & 1 & 1 & 0 & 0 & 0 & 3 & 0 & 0 \\
\hline Strotocrinus & 6 & 1 & 1 & $(1,2)$ & 4 & 1 & 1 & 1 & 0 & 1 & 1 & 0 & 0 & 1 & 4 & 0 & 2 \\
\hline Maligneocrinus & 5 & 0 & 1 & 2 & 3 & 0 & 0 & 1 & 0 & 2 & 1 & 0 & 0 & ? & ? & 0 & ? \\
\hline Cusacrinus & $(0,3)$ & $(0,1)$ & 1 & 1 & 2 & 0 & 0 & 1 & 0 & 2 & 1 & 0 & $(0,2)$ & $(1,2)$ & $(0,1,3,5)$ & 0 & 0 \\
\hline Nunnacrinus & $(0,3)$ & 0 & 1 & 0 & 2 & 0 & 0 & 1 & 0 & 2 & 1 & 0 & $(0,2)$ & $(0,2)$ & $(1,5)$ & 0 & 0 \\
\hline Glaphyrocrinus & 0 & 1 & 2 & 1 & 2 & 0 & 0 & 1 & 0 & 0 & 1 & 0 & 0 & 0 & 5 & 0 & 0 \\
\hline Manillacrinus & 0 & 1 & 1 & 1 & 1 & 0 & 0 & 1 & 0 & 0 & 1 & 0 & $(0,2)$ & 0 & 1 & 0 & 0 \\
\hline
\end{tabular}




\section{Elizabeth Carol Rhenberg}

1016 Timberline Apartment, Morgantown, WV 26505

731-446-5620

erhenber@mix.wvu.edu

Education

Ph.D. Degree in Geology

Expected:

West Virginia University, Morgantown, WV

Decemeber

Dissertation: Systematics, Paleoecology, and Biogeography of Early

2011

Mississippian Camerate Crinoids of the Nunn Member, Lake Valley Formation, in south-central New Mexico

Adviser: Thomas W. Kammer, PhD.

Masters Degree in Geology

Kent State University, Kent, $\mathrm{OH}$

Thesis: Biotic Interactions of Bivalves from the Late Cretaceous Coon Creek

Type Section of McNairy County, Tennessee

Adviser: Rodney M. Feldmann, PhD.

Bachelor of Science in Geology (Minor: Biology)

University of Tennessee at Martin, Martin, TN

Senior Research: Taphonomy and Depositional Setting of Oncolites Associated with Stromatolites in Laguna Bacalar, Mexico

Adviser: Michael A. Gibson, PhD.

Work Experience

Lecturer, Department of Geology, Appalachian State University

- Historical Lecture

- Historical Lab

- Enviromental Lab

Teaching Assistant, Department of Geology and Geography, West Virginia University.

- Taught Paleontology Lab

- Taught Earth History Introductory Lab

- Head TA for Earth History Lab

- Taught Geology 101 in large lecture setting (300+ students)

Teaching Assistant, Department of Geology, Kent State University

- Helped teach Paleontology Lab

- Taught Earth History Introductory Lab

Introduction to Physical Geology Lab Instructor, University of Tennessee, Martin 
Presentations and Abstracts

Rhenberg, Elizabeth C., Thomas W. Kammer. Low Endemism of Early Osagean (Mississippian) Camerate Crinoids in North America. Meeting: Geological Scoiety of America, Denver, Colorado, United States, October 31-November 3, 2010.

Rhenberg, Elizabeth C., Thomas W. Kammer. Systematic Review of Crinoid Genera from the Early Mississippian Lake Valley Formation (Nunn Member) of South-Central New Mexico. Meeting: Geological Society of America, Portland, Oregon, United States, October 17-23, 2009.

Rhenberg, Elizabeth C., D. Jade Simon, Lewis A. Cook, Magdalena K. Gill, William I. Ausich, and Thomas W. Kammer. Comparison of Early Mississippian Crinoid Generic Diversity Patterns Between the Lake Valley Formation of New Mexico and the Burlington Limestone Of Iowa. Meeting: Geological Society of America, Houston, TX, United States, October 5-9, 2008

Gill, Magdalena K., D. Jade Simon, Elizabeth C. Rhenberg, Lewis A. Cook, William I. Ausich, and Thomas W. Kammer. Crinoid Biodiversity in the Lower Mississippian Lake Valley Formation, New Mexico. Meeting: Geological Society of America, Houston, TX, United States, October 5-9, 2008

Rhenberg, Elizabeth and Michael Gibson. Preliminary Field Research of Stromatolites in Laguna Bacalar, Mexico. Meeting: Tennessee Academy of Science $114^{\text {th }}$ annual meeting, Columbia, TN, United States, November 18-19, 2004.

Gibson, Michael, and Elizabeth Rhenberg. An Exercise in Forensic Paleontology: Establishing the Authenticity of the “Kirkland Dinosaur Eggs." Meeting: Tennessee Acadmey of Science $114^{\text {th }}$ annual meeting, Columbia, TN, United States, November 18-19, 2004.

Beasley, Ryan, Adam Hames, Michael Latham, Mark McKee, Elizabeth Rhenberg, Chris Seifert, Yuko Takashita, Mary M. Ulderich, Jane Whitnel, and Michael Gibson. Comparative Taphonomy of Scyphocrinites loboliths from two west-central Tennessee Localities, Journal of the Tennessee Academy of Science, 78 (1), p. 28, 2003. Meeting: Tennessee Academy of Science 112th annual meeting, Johnson City, TN, United States, November 15, 2002.

Professional Affiliations and Offices

Sigma Gamma Epsilon

2002-2011

- Upsilon Chapter (2008-2011)

- Gamma Zeta Chapter

o President (2006-2007)

- Eta Alpha Chapter

o President (2003-2005)

o Secretary (2002-2003)

Geological Society of America

2006-2011

Paleontological Society

2008-2011

American Association of Petroleum Geologists

2008-2010

John H. 